Historic, Archive Document

Do not assume content reflects current scientific knowledge, policies, or practices. 


\section{PRICE LIST AND CULTURAL SUGGESTIONS} the Colorado Seed Co.

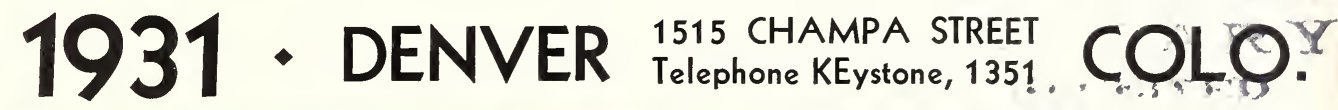

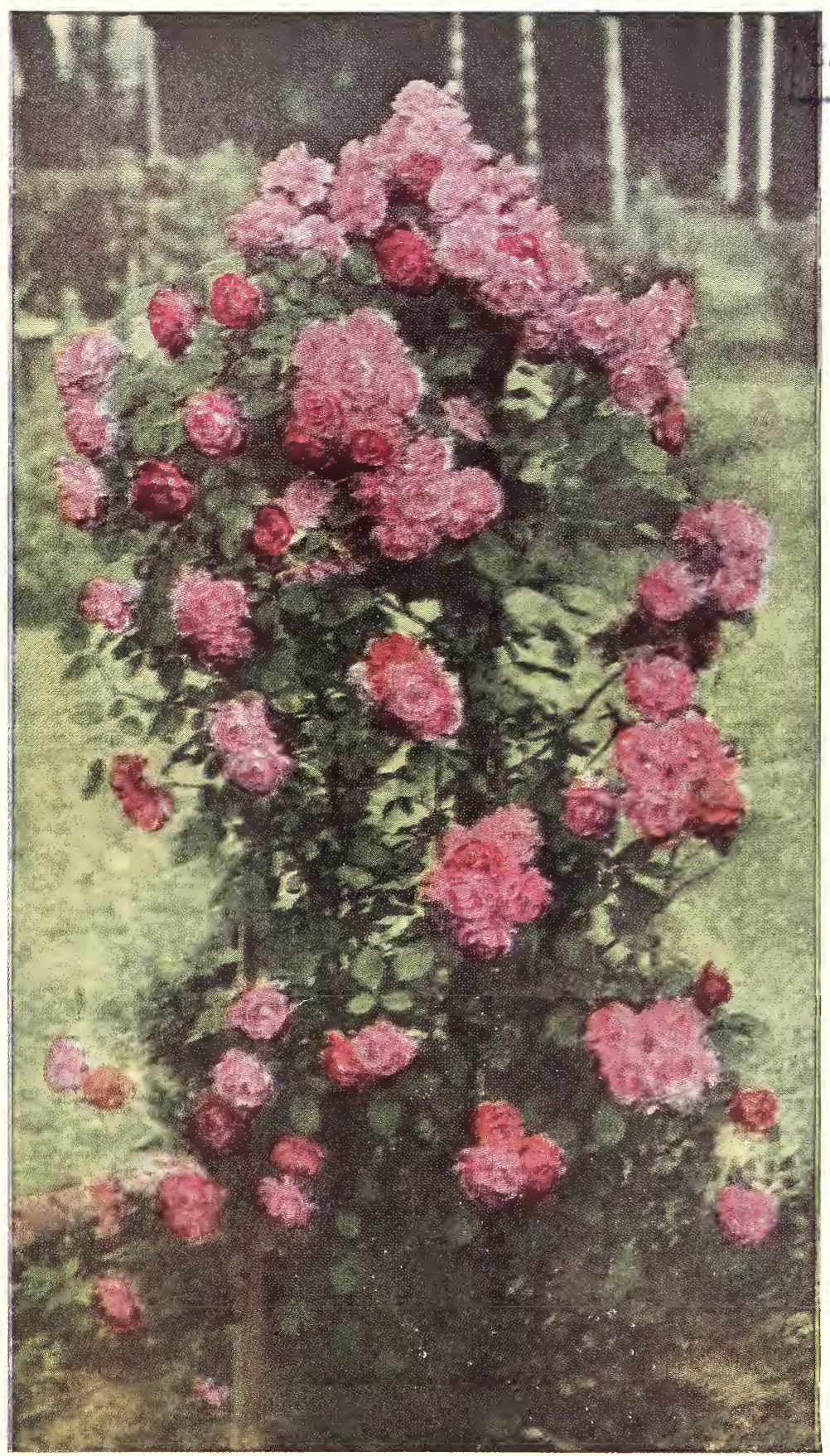

FEB 41931 t AMERIEAN" BEAUTY CLIMBING ROSE

A true American Beauty climber Rose, large and sweet scented.

As the illustration shows, the blooms are bright crimson pink in color and, like its parent, large in size and beautifully shaped.

The buds are slightly darker upon first opening, are magnificent. Their fragrance is not surpassed.

Remarkably hardy and seldom mildews.

SPECIAL

One sturdy field grown dormant bush for

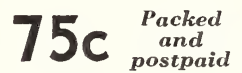

Five for $\$ 3.50$, postpaid

For other hardy Roses see page 22

The House

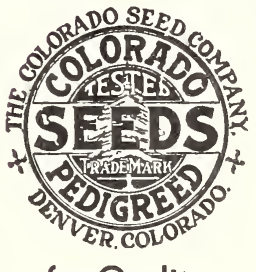

for Quality 


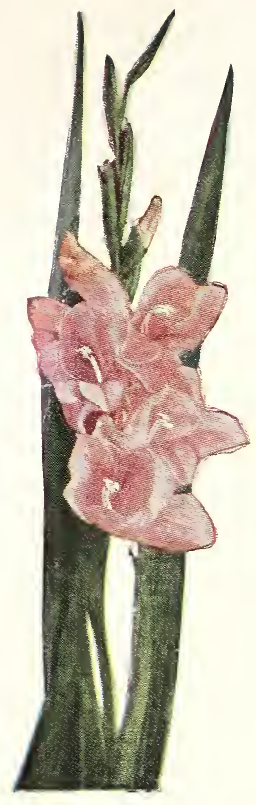

Evelyn Kirtland

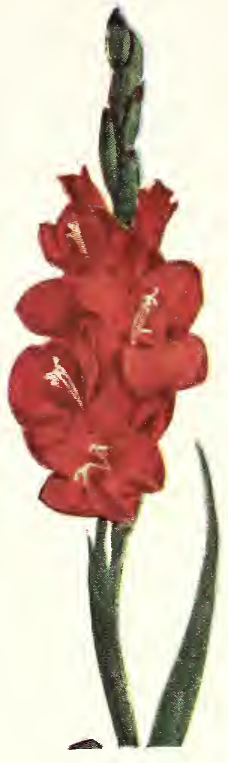

Virginia

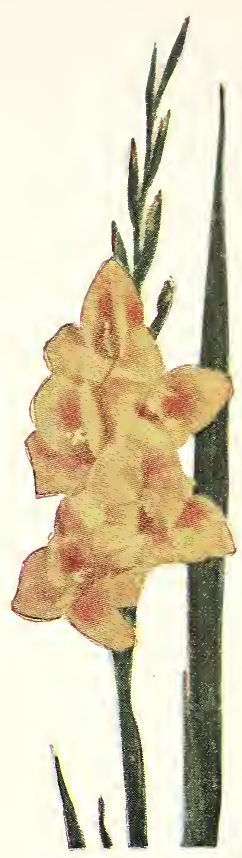

Alice Tiplady

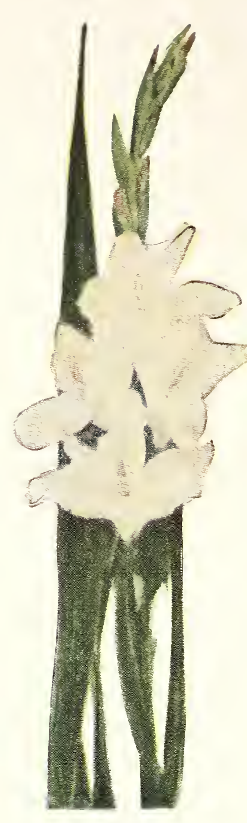

Souvenir

\section{Our \\ present \\ stock gives \\ you the \\ cream of \\ quality and \\ merit.}

Our Bulbs

are large

Colorado-

Grown

-full of

vigor.

\section{SUPERB GLADIOLUS Prices All}

This very attractive flower has grown into popularity with marvelous rapidity. All lovers of flowers find a suitable space for many of the wonderfully distinct varieties. You can not afford to be without a likeral planting.

The Gladiolus are the most attractive and useful of cut flowers of all the summer flowering bulbs. The long, graceful spikes that carry fifteen to twenty buds may be cut soon as the first lower buds show color; then kept in water each successive bud will develop and thus prolong the blooming many days. No other flower is thus equal, nor as easy of cultivation.

The planting season starts in April, and continues until in June, at intervals of two weeks; you thus have flowers from late July until frost time. Best results are obtained in a sunny position and placing the bulbs fully six inches deep. Water freely.

A very complete Cultural Leaflet on Gladiolus free with orders upon request.

\section{SPECIAL MERIT VARIETIES}

BETTY NUTHALL. A recent introduction of special merit. Light coral with pale orange throat, feathered carmine. Tall, straight, magnificent. Each 40c; doz. \$3.60.

CORONADO. The largest purest white ever seen by us. Came from Briggs of California-that says a lot. The edges are frilled, some have glossy purple throat. You will not regret buying of this. Each 75c; 3 for $\$ 2.00$.

GLORIANA. Recently imported. Large and beautiful. A rich salmon, bright clean color. Each $10 \mathrm{c}$; doz. $\$ 1.00 ; 100$ for $\$ 7.00$. LONGFELLOW. A very beautiful pink, straight and wiry spike Well spaced. Each 10c; doz. \$1.00.

MINUET. Large lilac-lavender with creamy throat. A color that has long been sought. You should have it in your assortment. Each $30 \mathrm{c} ; 12$ for $\$ 3.00$.

MOTHER MACHREE. Decidedly different from any Gladiolus in the market, and hard to describe, being a soft lavender. A color that grows on you the longer you look at it. Beautiful coloring of lavender and orange, subdued with neutral gray, like certain clouds just at sunset. Three rears ago the bulbs sold for $\$ 100.00$ each. We can now supply from importer's stock. for $\$ 100.00$ each. We can now

Each $\$ 4.00 ; 3$ bulbs for $\mathbf{\$ 1 0 . 0 0}$.
MR.W. H. PHIPPS. The Wonder Glad. Most marvelous in size with nearly all blossoms at one time. Lasts a week to ten days. Iridescent-pink. Each 10c; doz. \$1.00.

MRS. LEON DOUGLAS. Ground color Begonia-Rose, striped with flame and brilliant scarlet. Lip is pale lemon slightly speckled with ruby. The size of the flowers. we believe, is the largest in existence. Grows 4 to $5 \mathrm{ft}$. tall. Each 15c; doz. \$1.50; $\mathbf{1 0 0}, \$ 10.00$.

The following varieties are $8 \mathrm{c}$ each; 12 for $75 \mathrm{c}$; 100 for $\$ 5.00$.

Early Sunrise. Bright salmon-scarlet cream stripe. Tall, early. Golden Measure. Large, dark golden-yellow. The best yellow. Los Angeles. Shrimp-pink with orange-carmine throat. A "cutand-come-again" feature in no other variety.

Rose Ash. A new color in Gladiolus. Very vigorous.
Souvenir. Pure golden vellow Primulinus variety. Has the charm of vellow silk. Just the color for indoor decorations. One of the most useful Gladiolus.

Virginia. Rich, dazzling scarlet; makes a gorgeous display.

The following varieties are $6 \mathrm{c}$ each; 12 for $60 \mathrm{c}$ : 100 for $\$ 4.00$.

Anna Eberius. Dark velvety-purple with very dark throat. Baron Hulot. Dark royal purple.

Byron L. Smith. Beautiful lavender-pink on white ground.

Crimson Glow. Very large deep crimson on tall stalk.

Evelyn Kirtland. Large salmon-pink, darker at edges.

E. J. Shaylor. Pure deep rose-pink, darker throat, on long stem. Herada. Pure mauve with deeper markings in throat.

Mrs. Dr. Norton. Soft creamy pink.

Mary Pickford. (Chicago White.) Creamy white with soft sulMary Pickford. (Chica phur-yellow throat.
Prince of Wales. A charming coral-pink. Large, early, tall.
1910 Rose. Pure rose-pink, with narrow lines on lower petals.

The following varieties are 5c each; 12 for $50 \mathrm{c} ; 100$ for $\$ 3.50$.

Alice Tiplady. Primulinus type. Orange-saffron.

America. Beautiful lavender-pink flowers of large size.

Halley. Bright salmon-pink, with creamy blotch and red stripe Mrs. Francis King. Brilliant orange-scarlet, large blossom.

Mrs. Frank Pendleton. Flushed delicate pink with rich maroon blotch on lower petal.

Pink Wonder. An improved America, being soft lavender-pink.

\section{GLADIOLUS IN MIXTURE}

DEPENDABLE MIXED-OUR SPECIALTY. This is composed of many named varieties where we have surplus and also trial ground lots, all mixed by us. In this you get a wide range of colors, shades and types. It is a very superior mixture. Please not consider this as common mixture. Per doz. 40c; per 100 $\$ 2.75$; per $1,000 \$ 20.00$.

Special Mixtures of Colorado grown bulbs, grown mixed, all blooming size. Put up special, 12 in a package for $\mathbf{3 0 c}$.

\section{GENERAL COLLECTION OF 17 CHOICE NAMED GLAD BULBS}

This collection met with great approval last season, thus we are repeating it this season with several changes to make it different from last season though same value. This assortment includes one bulb each of 17 different varieties though not No two alike. All in Lithographed Carton,
with directions for culture. All postpaid for Buy collections for your friends. 5 for $\$ 2.25$, to one address. 
Page

Achillea (The Pearl).....P Page tconitum Monkshood...P 11 Alfalfa. .

Almonds, Flowering...... 24 Althea, Rose of Sharon... 24 tmaryllis............ B 17 Ampelopsis. S 10, P 11, R 26 Anchusa, Italica. $3 . . . P \quad 11$ Anemones ........... B 17 tquatic Plants........ 60 Aquariums.

Artemisia.

trtichokes............ 29

Asparagus........ $29, \ddot{R} 29$

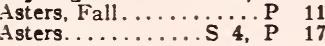

Baby Breath.

Corn, Seed. 41
50

Corn Sheller

Cranberry, Highbush...... 24

Crates, Egg............ 56

Creeping Bent.

Cress.

Cucumbers.

Cultivators.

Cups, Coop.

Dahlias.

S $6, \quad B \quad 18-21$

Daisy.......... S 6, 10, P 11

Dandelion Tools........44, 45

$\begin{array}{ll}\text { Day Lily.............. } & 11 \\ \text { Delphinium..... } & \text { P } 11\end{array}$

Digitalis, Foxglove......S 10

Disinfectants............ 55

Dog Supplies..........58, 59

Dutchman's Pipe.......... 27

Baby Chick Feed.

Bands, Plant. . .

49

Barberry..............24, 26

Barley.............. 41

$\begin{array}{ll}\text { Baskets, Hanging.............. } & 51 \\ \text { Baths, Bird........ } & 62\end{array}$

Beans. Field

Beans, Garden.

Beauty Bush. .

Beets, Stock. ...

Beets, I able.

Bermuda Onion Plants... 24, 35

Berries and 5 mall

Fruits

Bignonia Radicans

Bird Baths.

Bird Supplies.

3ittersweet Vine.

Blackberries.

Bleeding Heart, Third

Cover.

Boltonia

Books.

Borecole

Boxes, Flower

Boxes, Shipping

Bridal Wreath, Third

Cover

Brooders

Brooder Heater.

Brome Grass. .

Brussels Sprouts.

Burners.

Buttercups.

Butterfly Bush.

Egg Crates.

Egg Foods and Tonics... 55

Eggplant.........S 32, P 32

$\begin{array}{lll}\text { Egg Preserver. } & \ldots \ldots \ldots \ldots & \mathbf{5 6} \\ \text { Egg Teesters........... } & \mathbf{5 2}\end{array}$

Endive.

Equipment Cage.

Evergreen Seeds.

\section{Feeders}

Ferns, Hardy

.....

52
32
62

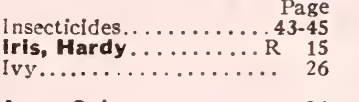

Japan Quince

Justrite Line.

Kaempfer's Bird Foods.

Kaffir Corn.

Kohl-Rabi .

Knives

Kudzu Vine

s $7, p$

Labels, Pot and Garden.

Lamps.

Lawn and Garden Re-

quisites.

Lawn Seeds.

Leek

Leg Bands.

Lettuce......

Lilac.

Lilies, Third Cover........ 16

Lily of the Valley......... B 17

Limber Glass.

Linum.

Loma.

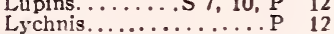

s $7,10, \stackrel{p}{p}$

$\begin{array}{ll}P & 12\end{array}$

Madeira Vine...... B 17, 27

Markers, Chicken

Matrimony Vine.

Millet.

Field Seeds.

Fish Supplies.

Milo.

Mock Orange.

Flowering Crab

Moe's Galvanized Poul-

\section{try Goods.}

$\begin{array}{lr}\text { Fiower Seeds, Annuals... } & 2-9 \\ \text { Flower Seeds, Perennials. } & 10\end{array}$

Foods, Bird...........61, 62

Dog.

Fish.

58,59

Montbretias.

Morning Glory

Moss.

Mulch Paper

Forget-Me-Not..........S 10

Forsythia.

Fountains

Fox Supplies

Mushroom Spawn

Muskmelon.

Mustard

iyrtle.

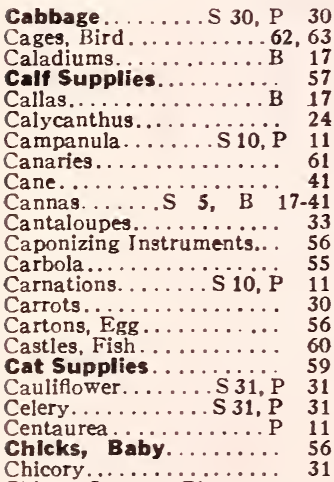

Chinese Lantern Plant.

...S 6, P 11

Chrysanthemums............ 6,11

Citron Melon.........

Cinnamon Vine.... B 17, R 27

Clover ............. 40, 41

Cod Liver Oil ..........

Colorado Blue Spruce..... 23

Columbines. . S 4, 10; $\mathrm{P}_{4}, 1$

Coop Cups.

Coops, Exhibition

Coops, Little Chic

Coops, Shipping. ....... 5

Coreopsis....... S 10, P 11

Corn, Pop.
Good Books (Misc.)..... 64

Garden Elfins.

\section{Garden Seeds.}

Garden Seeds in Bulk.

Garlic.

Gazing Globes.

Netting, Poult

Nitrogen.

Nozzles.

Oats.

Okra.

Onion Sets and Plants...33, 35

Orchard Grass.

Gladiolus, Second Cover

Globes, Fish...

Golden Elder.

Golden Glow

solden Rod.

Gooseberries.

Grafting Wax.

Grapes.

Grass and Field Seeds . 40, 4

Grasshopper Polson... 45

Grist Mill........... $\ddot{7}, \ddot{10},{ }_{12}^{50}$

Harris Protectors.

Hedge Shears...

Helenium. . . .

Heliopsis

Hemerocallis.

Oxalis, Summer.

B 17

Pans, Bulb

Pansies.

Pansy Violet

Parsley.

Peas, Fieid

Peas, Garden.

Peanuts.....

Peatigree Blank......42, 55

Pentstemon........ $10, \dot{\mathrm{p}} 12$

Peonies...............R 15

$\begin{array}{ll}\text { Peonies................ } 35, \mathrm{P} & 15 \\ \text { Peppers.... } & 35 \\ \text { Perennial Flower Seeds. } & 10 \\ \text { Perennial Plants, Third } & \end{array}$

Cover..............11-15

Pest Exterminators.... 44, 45

Phlox......... 8 8, 10, R 13

Pigeon Supplies. . . . . . . 56, 57

Pinks, Hardy....... $10, \mathrm{P}$

Planet Jr. Toois........ 50

Planet Jr. Tools........

Plant Bands.

Plant Fibre.

Plants, Perennial.

Plant Protectors.

Plant Supports.

Hop Vine............ 27

Horseradish 32

Hotkap Protectors....... 49

Hotbed Covering.

Houses, Bird

Planters and Sowers.

Platycodon...

Platycodon........... $8,10, \mathrm{P}$

Pots, Fibre.

Pots, Flower.

Poultry Books.
Geum........... S, 10, P 1

Glazing Materiai.

\section{EXPRESS RATES}

Poultry Supplies Pag

Powder Hlowers. ......44,45

Preserver, Egg........... 56

Privet

Pruning Shears.

Pumpkins.

Pyrethrum........s io, $\dot{p}$

Q.-W. Dog Remedies.... . 58

Rabbit Supplles... . . . . 54, 57

Radishes.

Raffia

Rakes, Garden

Rape, Essex.

Raspberries.

Ribbon Grass.

S $37, \dot{R} 28$

Rock Garden Plant....R 13

... 14

Roofing............. 54

Rubber Toy. ............

Rudbeckia............. P 13

Rutabagas............. 37, 38

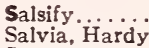

Saws.

Screen Glass

Seed, Bird.

61,62

Shears and Prune...... 50

Shells and Chips......47, 60

Shipping Boxes........... 56

Shrubs, Third Cover...24, 25

Snowball...

Snowberry.

vers, Seed.

Spades and Shovels.... 48

Speltz

Spinach

Spireas. Third Cover

Spratt's Line. . .... 58, 59, 62

Sprayers and Spray

Pumps.

Sprinklers.

Stakes.

Statice.

Stands, Cage

Stoves, Brooder.

Strawberries.

Sumac.. .

Summer Bedding Plants 17

Summer Flowerlng 


\section{Special Quantity Prices Lawn and Field Seeds}

These prices are present values, subject to market change, net for cash $f$. o. b. Denver.

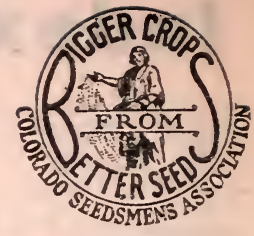

\section{SEEDS FOR THE LAWN}

10 lbs. $25 \mathrm{lbs}$ per lb. per lb.

Champion Lawn Grass Mixture. .

Shady Nook Lawn Grass. .

Special Mixture to Crowd Dandelions.

Sunnyside Lawn Grass Mixture. .

Polo Grounds Mixture....

Ky. Bluegrass, Fancy

Ky. Bluegrass, Extra Clean.

Bluegrass and White Clover Mixture.

White Clover, Fancy, Clean

White Clover, Choice. .

Poa Trivalis, for Shade

Red Top, Fancy, Hulled.

English Bluegrass, Meadow Fescue.

Pcrennial Rye Grass, Imported, Pacey's.

Rye Grass, American Grown

Red Fescue, Creeping.

Creeping Bent, Imported German.... . ...

Seaside or Coos Bent, from Washington... .....

Astoria Bent, from Washington. Sealed pkgs. .

Colonial Bent.

Chewing Fescue, Australian

Bermuda Grass. .

\section{GRASS SEEDS}

Timothy: Standard Grade.

Orchard Grass, Imported.

Brome Grass, Awnless, Dakota Grown, Recleaned.

Sudan Grass, Northern Grown

Morton's Pasture Mixture.

\begin{tabular}{rrr}
$\$ .45$ & $\$ .42$ & $\$ 40.00$ \\
.55 & .50 & 45.00 \\
.75 & .65 & 60.00 \\
.42 & .40 & 38.00 \\
.30 & .28 & 25.00 \\
.50 & .45 & 42.00 \\
.60 & .55 & 50.00 \\
.55 & .50 & 45.00 \\
.60 & .55 & 50.00 \\
.55 & .50 & 45.00 \\
.65 & .60 & 50.00 \\
$.321 / 2$ & .30 & 28.00 \\
.25 & .22 & 20.00 \\
$.221 / 2$ & .20 & 17.00 \\
$.171 / 2$ & .14 & 12.00 \\
.55 & .50 & 45.00 \\
1.20 & 1.15 & 110.00 \\
\hline 1.65 & 1.60 & 150.00 \\
1.85 & 1.75 & 160.00 \\
1.30 & 1.25 & 120.00 \\
.55 & .50 & 45.00 \\
.45 & .42 & 40.00
\end{tabular}

$.131 / 2$

$.13 \quad 12.00$

.25

$.321 / 2 \quad .30$

$.121 / 2$

40.00
Per

100 lbs.

Alfalfa Northern Grown. .

Alfalfa, Domestic, Fancy..

Alsike Clover, Fancy.

Sweet Clover, White Blossom, Hulled.

Sweet Clover, Yellow Blossom, Hulled. .

\section{ALFALFA AND CLOVER}

10 lbs. 25 lbs.

per lb. per lb. $100 \mathrm{lbs}$

$\$ .40 \quad \$ .37 \quad \$ 36.00$

$\begin{array}{lll}.28 & .25 & 24.00\end{array}$

$\begin{array}{lll}.25 & .23 & 22.00\end{array}$

$\begin{array}{lll}.32 \frac{1}{2} & .30 \quad 28.00\end{array}$

$.12 \frac{1}{2} \quad .10$

9.25

$.12 \frac{1}{2} \quad .10$

9.25

\section{GRAIN SEEDS}

Wheat, Marquis ....... .06

Barley, Colsess ........... . .06

Oats, Swedish, Select. :

Oats, Victory...

Spring Rye, Colorado

Grown...

Speltz.

Flax Seed.

$061 \%$

$.06 \quad .05$

$.06 \quad .05$

3.00

3.50

4.25

3.25

3.50

$\begin{array}{lll}.06 & .05 & 3.50 \\ .06 & .05 & 3.00\end{array}$

$\begin{array}{lll}.10 & .08 & 6.50\end{array}$

\section{FORAGE AND FODDER}

Early Amber Cane....... . . .071/2 $\quad .06$

Kaffir Corn, White........ .05 $\quad .04$

Milo, Yellow............ .05 $\quad .04$

4.25

3.00

3.00

Essex, Rape, Imported. . . $\quad .15 \quad .12$

10.00

\section{MILLETS}

$\begin{array}{llll}\text { White Wonder Very Hardy } & .06 & .05 & 4.00 \\ \text { Siberian, Red.......... } & .06 & .05 & 3.25 \\ \text { Manitoba, or Hog........ } & .06 & .05 & 2.75\end{array}$

\section{SEED CORN}

Minnesota No. 13........ . .081/2 $\quad .06$

4.00

Colorado. Yellow Dent.... . .081/2 .06

4.25

Colorado White Dent

White Australian.
$.081 / 2$

$.081 / 2$
.06

.25

\section{Poultry Foods}

Mixed Feeds for Hens and Growing Chicks-Standard Formula Mixtures are described and priced on page 54. Special Feeds for Baby Chicks are enumerated on page 55.

\section{POPULAR GRAINS FOR FEEDING}

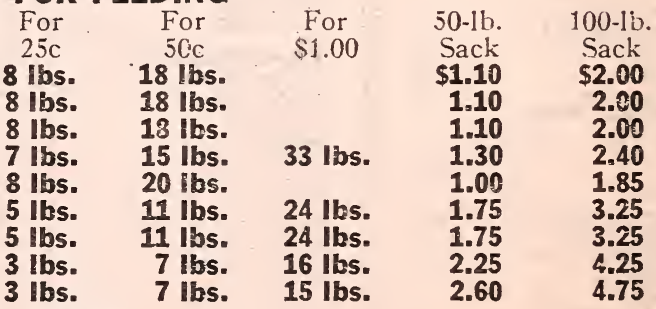

Wheat, average grade, clean.

$$
25 \mathrm{c}
$$

Corn, average.

8 ibs.

Rolled Barley .

8 lbs.

Cracked Corn, yellow, screened, extra nice.

Bran, Wheat, clean, white...

Green Cut Bone, dried, coarse and fine

Fine Bone for chicks and mash, odorless, clean.

Meat Scraps, Colorado; high protein.

Blood Meal, Colorado. Per pound, 10c.... 3 lbs.
$\quad$ For Oyster Shell, Grit and Charcoal, see prices on page 54.

$7 \mathrm{lbs}$.

15 Ibs.

Should you not find in this catalog what you want, please write us.

WE SOLICIT YOUR ORDERS

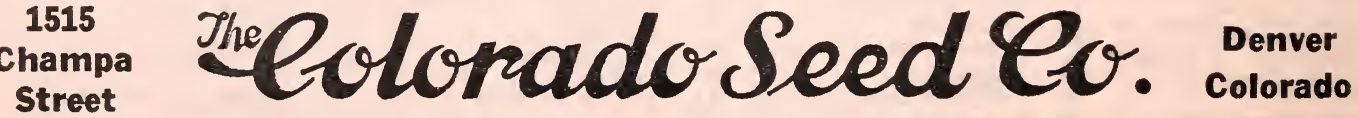




\section{Holes of Garden Golf Every Day All Summer}

GURE, why not? Most home grounds afford sufficient ground space for an abundance of distinctive plantings; and the Garden Golf

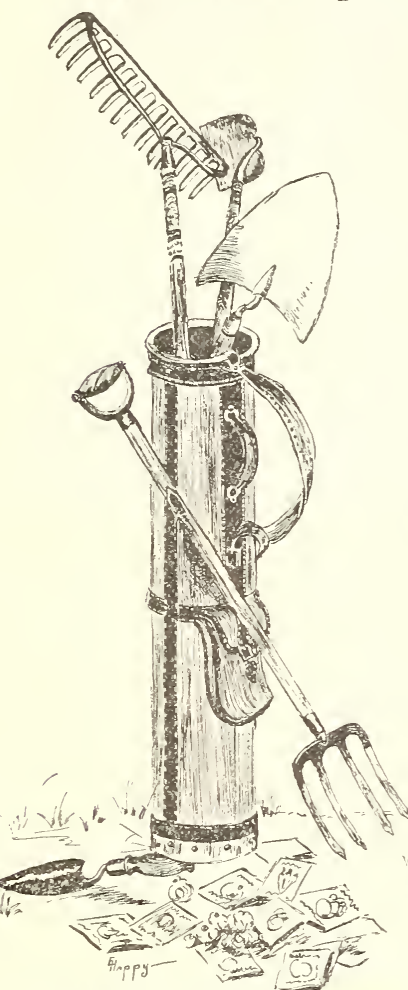

HOW TO ORDER. We ask our customers to follow these instructions and fill out order sheets carefully.

ORDER EARLY. Kindly send in your order early; in the rush season of March and April there are unavoidable delays. Late buying is trying to you and more difficult to our over-busy

staff. Perishable goods are sent at a suitable planting time.
POSTAGE PREPAID, On all Vegetahle and Flower Seeds, Bulbs Plants, etc., unless otherwise stated. The U. S. Mail delivers our seeds direct to your door. For Grass, Grain and Field Seeds, also other goods that are not priced "prepaid," see Parcel Post Schedule on back of printed order blank, and on page 64 .

PRICES. Our prices are made on a very conservative basis. We hope you will look over our catalog carefully, comparing quality above all. ("There is hardly anything in the world that someone cannot make a little worse and sell a little cheaper, and the people who consider price only a re this man's lawful prey."-John Ruskin.) TERMS: Cash with order. Post Office Money Order, Express Order or Exchange on Denver; small amounts may be sent in clean postage stamps. Please do not ask us to ship C. O. D. unless you remit one-third of the order.

ERRORS. Yes, we make them, in spite of all care. Write us at once in full that we may make the adjustment to your entire satisfaction. Keep a copy of your order and use our printed order blank. Additional order sheets sent on request.

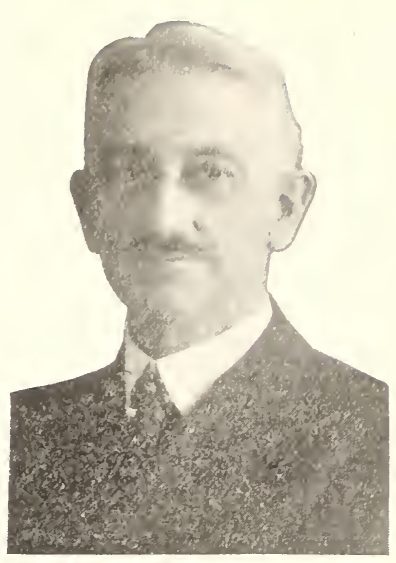

C. R. ROOT

President and General Manager

Thirty-nine years of experience in the Seed and Nursery business in Colorado.

\section{Depom lablo}

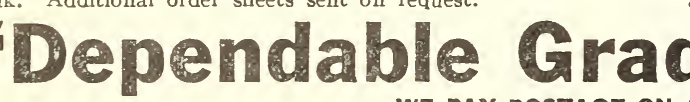

The flower seeds listed in our catalog are especially selected for hardiness and durability in the territory where this book is sent. There are none of the undesirable varieties. When you order seeds from this book you can rely on getting only dependable seeds of merit.

For your further guidance and to make the results of your efforts more certain you will find cultural directions on the packet. Flowers are usually known as Annuals, Biennials and Perennials.

Annuals bloom and ripen seed the first year and then perish. Biennials do not generally bloom the first year and are in perfection the second year only.

Perennials flower several years in succession. many blooming the first year from seed sown early and are used for permanent plantings.
TESTED SEEDS. We test all our seeds for purity and germination and have a large electrically-heated tester approved by our State Seed Laboratory.

GARDENERS. We usually have names of dependable experienced gardeners that we will gladly give to customers.

NON-WARRANTY. While we take all the care possible in selecting our seeds, shrubs, bulbs and plants, and we believe they will give satisfaction, we cannot guarantee them. All gardeners of experience know that success even with seeds of the quality of our DEPENDABLE GRADE depends largely on the weather conditions and proper cultivation, thus in common with all of the American Seed Trade Association, we. therefore, cannot guarantee the crop nor give any warranty, express or implied, as to their growth, description, quality or productiveness; and we will not be in any way responsible for the crop. If the purchaser does not accept the way responsible for the crop. If the purchaser does not accept the unbroken package and the purchase price will be refunded. It the unbroken package and the purchase price will be refunded. It the other seeds to same value.

If you have friends that would be interested in receiving a copy of our catalog, we will consider it a favor if you give us their names and addresses.

\section{"I

FLOWER SEEDS

For price list Perennial seeds, see page 10.

Hardy Perennials and Biennials may be sown either in early fall or spring and require no protection through the winter. Hardy Annuals may be sown either in late fall or spring. They often self-sow in the fall.

Half Hardy Annuals, Biennials and Perennials cannot be sown in open ground until warm weather; they may, if desired, be started early inside and transplanted afterwards. 'The latter two need protection in winter or may be carried through in cold frames or greenhouses.

Cultural Leaflet on Annuals Free When Asked For.

In this list we include both annuals that blocm, then die, and several tender perennials that bloom freely the first year. 


\section{SWEET PEAS Selected Tested Seed}

Sweet Peas, with their beautiful raried colored flowers, take the lead among the many different kinds of annual and perennial plants. Your flower garden will not be complete without them. There are many varieties which are identical and others which lack size, color or some other characteristic, which all first-class sorts should have. We offer herewith a list of varieties, which have been carefully selected for their large size and marvelous colors, and every variety is entitled to a place in the front rank of Sweet Peas.

\section{Choicest and Finest}

\section{Orchid Flowering Butterfly}

\section{Spencer Sweet Peas}

The Spencer or Butterfly varieties are the latest and best in Sweet Pea culture. Most of them have frilled edge and many are hooded shape. All are very large and usually four blossoms on a long stem, making them excellent for bouquets.

We are leaders in this market for quality seed and dependable varieties.

This season we have procured direct from The $W$. Atlee Burpee Co. Seed Farms an assortment of Spencer Sweet Pea seed in bulk. This stock is strictly dependable.

Nitragin Bacteria for Sweet Peas, 25c. Postpaît.

\section{NAMED SPENCER VARIETIES}

This list includes the very choicest of the popular varieties. There are many similar kinds in Sweet Peas with attractive names, but you cannot go amiss in planting any of the following. Our prices are very reasonable for the grades we supply. Any following separate varieties:

PRICES-Large packets 10c; 1/2-oz. pkg. 15c; oz. pkg. 30c; 1/4-lb. pkg. $90 \mathrm{c}$; unless priced otherwise. All postpaid.

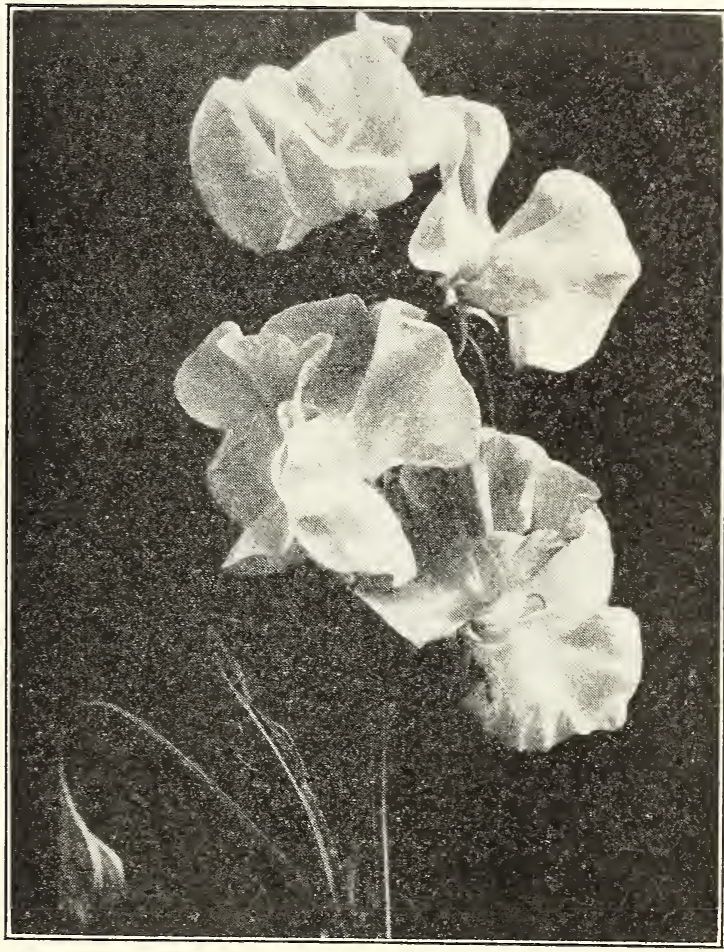

Mary Pickford-A Splendid Orchid Flowering
Austin Frederick Improved. A new large lavender. Believed to be best of the lavenders, being bright and pleasing. Very large.

Commander Goodsall. Dark blue; a violet-blue.

Constance Hinton. Large true Spencer, white blossom. Being black-seeded, it germinates more readily than whiteseeded. Extra vigorous grower.

Crimson King. A rich deep crimson that does not burn. Especially long stem. Is really better than King Edward.

Defiance. A beautiful large orange-scarlet. Much admired.

Elfrida Pearson. This old favorite is a lovely pink throughout, the buds and flowers being tinted with salmon-pink with the margins a darker pink.

Fluffy Ruffles. Burpee's product of an exquisite light cream-pink. Pkt. 15c; $1 / 2$ oz. 35c; 1 oz. 65c; $1 / 4$ Ib. $\$ 2.00$. Hawlmark Cerise. A bright salmon-cerise, making it a wonderfully attractive shade. It is an excellent flower.

Hebe. This giant rosy-pink supersedes the several pinks that were formerly so popular. Large and well proportioned.

Heavenly Blue. A new Delphinium blue of great merit.

King White (Improved IVhite Spencer). Undoubtedly the best white now in cultivation. Is remarkable for its immaculate purity of whiteness and the perfect finish of the flowers. Almost invariably four blossoms on a long, stout stem.

Majestic Cream. Rich deep cream. Superior to Primrose. Mary Pickford. A fine light and dainty cream-pink, suffused with salmon. A color hard to describe, and harder to surpass.

Miss California. Orange-salmon with cream-pink. Very popular.

Royal Purple. The best purple. A very true color, on long stems.

Senator Spencer. A deep claret or chocolate, striped and flaked on a ground of light heliotrope, makes a very charming combination. Blossoms are extra large, wavy and drooping, usually four on a stem.

Snowball. Produces flowers of dazzling whiteness. Very fragrant.

Warrior. A giant flower of rich chocolate-maroon.

Youth. A large flower. Is pink to almost white; a very attractive picotee edge.

Our Spencer Sweet Pea Collection

Five 10c packets and one 1-0z. 20c package. 6 packets in all for 50c.

1 Pkt. Crimson King

1 Pkt. Majestic Cream

1 Pkt. Elfrida Pearson.

1 Pkt. Commander Goodsall
1 Pkt. King White

10c 1-oz. Pkg. Spencer Varieties, Mixed

$10 \mathrm{c}$

Regular Value

ALL TO YOU, POSTPAID, FOR -
From above list $20 \mathrm{c}$

$\overline{70 c}$ 


\section{Early Flowering Varieties and Special Mixtures}

If you wish extraordinary and distinctive Sueet Peas select from page 2 EARLY FLOWERING OR WINTER FLOWERING ORCHID SPENCER SWEET PEAS

These are a distinct strain of Spencer type flowers that bloom fully three weeks earlier than other Spencers. The original purpose in breeding up these varieties was for winter blooms in greenhouses, which has made wonderful
change in Sweet Pea culture indoors. It was soon discovered that these same change in Sweet Pea culture indoors. It was soon discovered that these same
varieties would do equally as well in our gardens by producing fine, large blossoms considerably in advance of other strains. We recommend them for garden culture as well as for florists indoors.

Prices: Per pkt. $10 \mathrm{c} ; 1 / 4$ oz. 20c; $1 / 2$ oz. 35c; oz. $60 \mathrm{c}$; unless otherwise priced.

Ball Orange. Rich orange. $1 / 4$ oz. $25 \mathrm{c}$; $1 / 2$ oz. $45 \mathrm{c}$; oz. $75 \mathrm{c}$.

Ball Rose. Rose-pink.

Burpee's Orange, Early. A clear beautiful orange color. $1 / 4$ oz. 25c; 1/2 oz. $45 \mathrm{c}$; oz. $75 \mathrm{c}$.

Columbia, Early. Bi-color of pink and white. Heavy producer.

Flamingo, Early. A beautiful orange-red that is especially admired.

Glitters, Early. Bright fiery orange, wings deep orange.

Grenadier, Early. Brilliant poppy-scarlet. 1/4 oz. 25c; 1/2 oz. 45c; oz. 75c.

Harmony, Early. A fine new clear lavender.

Lavender King, Early. A beautiful large lavender.

Mrs. Calvin Coolidge, Early Large, magnificent flower of rich salmonpink. Usually four on a long stem.

Mrs. Herbert Hoover. Clear blue. Pkt. 15c; $1 / 4$ oz. $40 \mathrm{c} ; 1 / 2$ oz. $75 \mathrm{c} ; 1 \mathrm{oz}$. $\$ 1.25$.

New Blue, Early. Beautiful deep blue. 1/4 oz. 25c; 1/2 oz. 45c; oz. 75c.

Rose Queen, Early. One of the best pinks and a leader in the flower shops.

Silver Blue, Early. A delicate shade of lavender-blue.

Snowstorm, Early (Improved). Pure white, large waved and extra long stems.

Spring Song, Early. Rich, bright rose-pink, flushed salmon. In sunlight as well as artificial light, it is especially beautiful.

Superior Pink, Early. Morse's new rose-pink. Better than Mrs. Skaach.

Venus, Early. White with blush-pink wings.

Vulcan, Early. A grand sun-proof, vivid scarlet.

White Harmony, Early. An excellent large, beautiful white, exquisitely

waved and frilled. Pkt. 15c; $1 / 4$ oz. 35c; oz. $\$ 1.00$.

Zvalaneck's Rose, Early. Deep rose. Giant blossom. Large. One of the best.

Early Flowering Orchids, Mixed. Mixed by us. Gives you a beautiful

assortment. Pkt. 10c; $1 / 2$ oz. $30 \mathrm{c} ;$ oz. 50c; $1 / 4$ Ib. $\$ 1.50$.

\section{SWEET PEA LITERATURE}

64-page book, "Better Sweet Peas," by Geo. H. Ball. Is valuable to a commercial grower. Price, $75 \mathrm{c}$, postpaid. for. Cultural Leaflet by C. $R$. Root free with orders, if asked

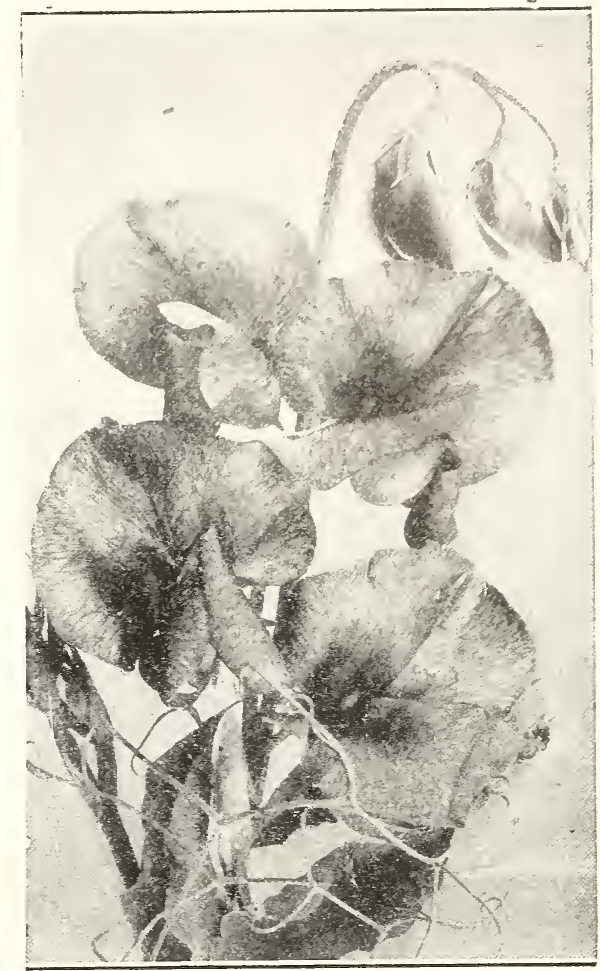

\section{OUR “DEPENDABLE” CHAMPION MIXTURE}

Consists of the best named Grandiflora varieties, also many Spencers, all mixed by us. This mixture is decided!y different from others. we buy separately many named varieties and trial-ground sorts to mix into this stock. There is positively nothing better in mixtures at the price.

Large packet 5c; oz. pkg. 15c; 2-oz. pkg. 25c; 1/4 Ib. pkg. 40c; 1/2 Ib. pkg. 65c; lb. pkg. \$1.25. AII postpaid.

\section{SPENCER VARIETIES MIXED SWEET PEAS-SILVER MEDAL STRAIN}

Too much cannot be said in praise of the merit of this mixture. We arranged with Mr. Waller, a very extensive seed grower in California, to supply us stock from his Silver Medal strain, which consists of many standard varieties of Spencers. To this we added some separate varieties that there may be a well-balanced assortment of colors. All these make it far superior to these so-called mixed which are grown-mixed and only a few colors prevail. Our mixture is a very distinct class.

Liberal packet 10c; oz. 20c; 2-0z. 35c; 1/4 Ib. pkg. 60c; 1/2 Ib. pkg. \$1.10; Ib. pkg. \$2.00. All postpaid.

CULTURE. The seed should be sown as soon as the ground can be worked, in trenches 8 to 10 inches deep in a position fully exposed to the sunlight and air on both sides of the row. Cover with about one inch of soil, pressing it down firmly. As the plants grow, draw the soil to the plants until the trench is full. This method will give a long vine in the soil, which will make innumerable roots and gather nourishment and moisture through a dry spell. As soon as they are above ground, thin out to 2 to 4 inches apart to enable the plants to fully develop if you desire large flowers. They should be staked up either with branches of brush or stout stakes on which wire netting has been fastened. These should be at least 4 feet high. During dry weather water thoroughly and frequently. The flowers should be cut as of ten as possible to prevent the plants from running to seed which stops them from continuing to bloom.

Our prices are postpaid.

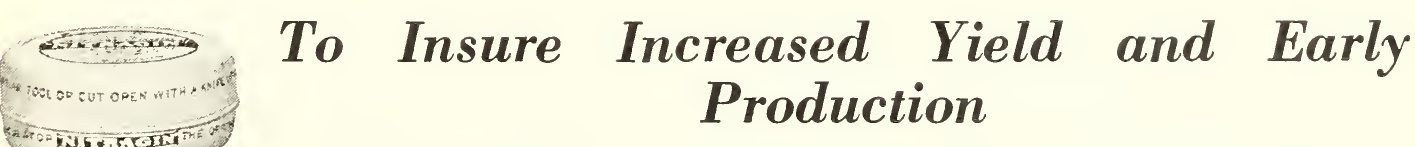

NITRAGIN BACTERIA is very beneficial. Be sure to inoculate your seed with it. Does wonders in producing growth and bloom. Small-size package, enough for 5 pounds of seed, only 25c, postpaid.

SCOTCH SOOT scattered around on soil near Sweet Peas will do much toward bringing out color in the blooms.

1-Ib. pkg. 10c. Postpaid 20c. 10-Ib. pkg. 90c; postage extra.

FINE BONE MEAL applied on surface of ground and worked in, is very beneficial to Sweet Peas. Lb. pkg. 10c; 5-Ib. pkg. 30c; 10-Ib. pkg. $50 \mathrm{c}$; not postpaid.

TRELLIS WIRE FOR SWEET PEAS (Not postpaid)

36 inches wide. Per foot........5c

48 inches wide. Per foot........6.6

60 inches wide. Perfoot.........8c 


\section{Three Flower Specials for Everyone}

\section{Asters-New Types}

The queen of the summer-blooming plants. The Aster has progressed and improved by cultivation until many of the new varieties in their improved form bear a striking resemblance to the Chrysanthemum. The long stem makes them desirable for cut flowers as the blooms last long in water. The popularity of the Aster is not due entirely to the flower, but to the ease with which they are raised. Asters thrive in any good soil, prepared the same as for a crop of vegetables. Any extra care taken in the preparation of the soil and cultivation is repaid by larger and more beautiful flowers. They require a sunny exposure and a well enriched soil. Sow in hotbeds, pots or boxes in the house in March and April, transplant 18 inches a part after danger of frost is past. The seed can be sown in open ground in May. Cultural leaflet on requestAsters. When and how to start the seed.

If Aster seed is treated with SEMESAN POWDER it will do much toward preventing wilt and plants dying just at blooming time.

Early Royal. An early, large-blooming type with elegant rounded double flowers carried on very long

Deep Rose Lavender Purple

Shell-Pink White $10 \mathrm{c} ; 1-8$ oz, 30c.

Mixed, all colors, pkt. $10 \mathrm{c}$

Sunshine. A beautiful new type of Aster, anemoneflowered particularly fine for cutting.

flowered; particularly fine for cutt

Giant Branching (Improved Crego). Our stock is grown and carefully selected at the Bodger Farm where "Asters are King." They are improved to be very large, well branched, and on long stems. For home gardens they are next in quality to the New American Beauty type. Supplied in seven distinct

Crimson Light Blue White Lavender Purple Deep Rose Pink Each of the above, pkt. $10 \mathrm{c} ; 1-8 \mathrm{oz} .25 \mathrm{c}$.
All colors, mixed. Pkt. $10 \mathrm{c} ; 1-8 \mathrm{oz} .20 \mathrm{c} ; 1 / 4 \mathrm{oz}$.

American Beauty Aster. This is the latest and grandest of Bodger's productions. The blooms crimson. Fire-red. Purple. Lavender. Rose. Light rose. White Beauty. Pure white. Each of the above, pkt $15 \mathrm{c}$

All colors, mixed. Pkt. $10 \mathrm{c} ; 1-8$ oz. $50 \mathrm{c}$.

Good Mixed Asters. Many types and colors. Pkt. $10 \mathrm{c} ; 1 / 4$ oz. $30 \mathrm{c}$.

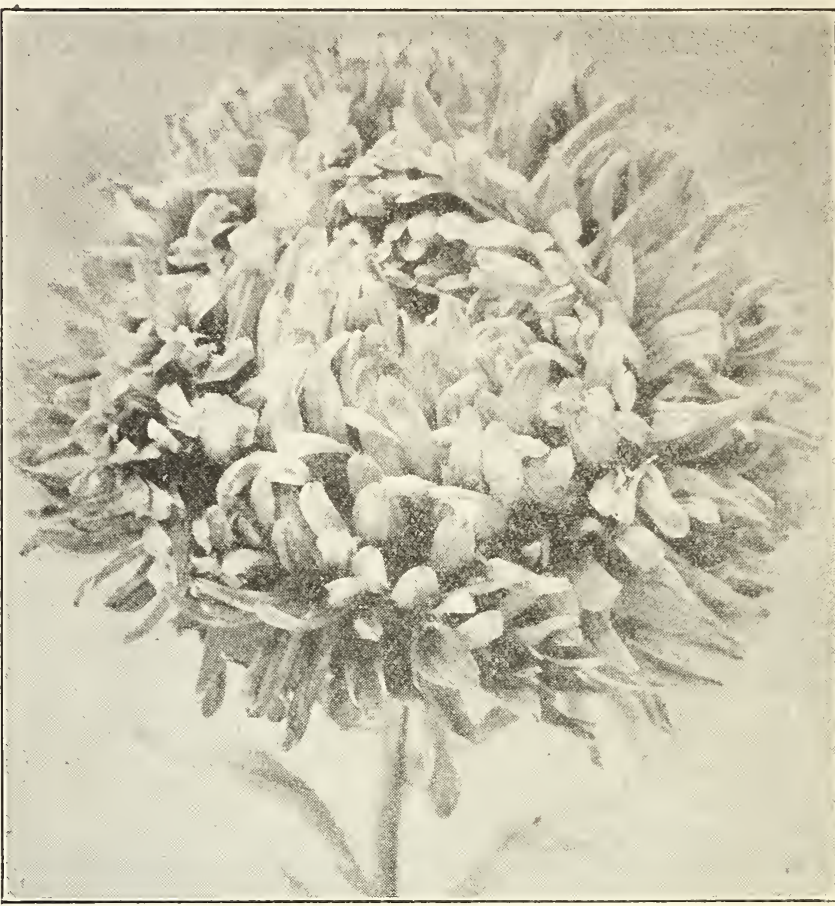

New Early Royal Aster. (Five separate cclors and mixed in 10c pkis.)

\section{OUR ASTER COLLECTION}

Consists of five $10 \mathrm{c}$ packets, separate colors, and one Giant-Branching Mixed, put up in one large illustrated envelope, for $50 \mathrm{c}$, postpaid.

\section{Rocky Mountain Columbine $\left(\begin{array}{c}\text { Aquilegia } \\ \text { Coorulaa }\end{array}\right)$}

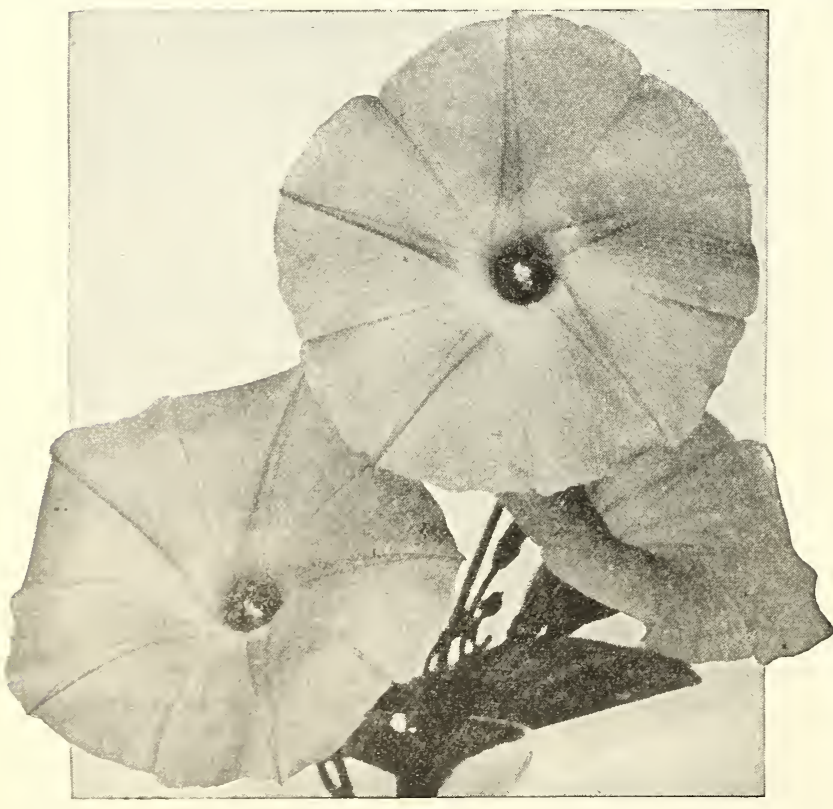

The true blue native Colorado-grown; so much admired by all and rapidly becoming very popular. For airy grace and prolific bloom they are unsurpassed. Both seeds and plants are mountain-gathered, assuring you the Real Colorado State Flower. Seeds, pkt. $15 \mathrm{c}$ $1-8$ oz. 35c; oz. $\$ 1.75$. Plants, 3-yr.-old native roots, each $20 \mathrm{c}$; $\$ 2.00$ per doz.

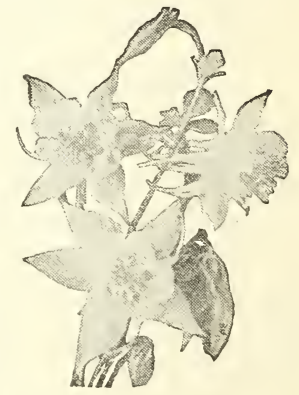

\section{Clarke's Mammoth Blue Morning Glory}

Developed originally by Mr. Clarke, of Denver, who worked for years to perfect this gorgeous and exquisite strain. The flowers are enormous, blooms averaging 4 inches across. The color is a fixed sky-blue, most unusual and distinctive; almost baffling descriotion, and the abundance of blooms, open from sunrise till afternoon, is most beautiful. It will grow upwards of 15 feet in a season and is most effective for backgrounds, behind Dahlias, Hollyhocks and other tall flowers; also for trellises, fences, porches and covering walls. If seed is punctured with a 2 for 25 c; postpaid.

Clarke's Mammoth Blue Morning Glory. (Pkt. 15c; 2 for 25c.)

BETTER SEEDS MAKE BETTER GARDENS 


\section{ANNUAL FLOWER SEEDS}

\section{A Garden of Annual Flowers is a Pleasure lhat Lasts All Summer}

10.

PERENNIAL FLOWER SEED Listed separately on page

PERENNIAL PLANTS for year in aud year out permanent lantings. See fourth cover page; also pages 11 to 15 , inclusive. T An GARDEN FLOWER SEED MIXTURE gardens, waste places, etc. Pkt. 5c; oz. 15c; 1 ib. 50c.

\section{ACROCLINIUM}

Produces daisy-like flowers, when cut in bud, can be dried and used for winter bouquets. Pkt. 10c; $1 / 4$ oz. 20c.

\section{AGERATUM}

Annual Mexicanum. Light blue, 18-inch. Pkt. 10c; $1 / 1$ ox. 25c. ALYSSUM, SWEET

Maritimum. Purc white, very fragrant. Pkt. 5c; 1/2 oz. 15c oz. 25 c.

Little Gem. Very dwarf and compact. Pkt. 10c; $1 / 4$ oz. 25c oz. 75c.

\section{AMARANTHUS}

Brilliant foliaged annuals, some of the varieties bearing curious racemes of flowers. All are useful in borders of tall plants among shrubs, or for the centers of large beds. Do not grow them too closely together, but give them sufficient room to develop their full beauty. When flowered in small pots under glass they are very charming.

Tricolor (Joseph's Coat). 30-inch. Pkt. 10c; 1/4 oz. 15c. Caudatus (Love Lies Bleeding). Drooping red spikes, 3 feet. Pkt. 10c.

Mixed. Many kinds. Pkt. 10c; $1 / 4$ oz. 15c; $1 / 2$ oz. 25c. ANTIRRHINUM (Snapdragon)

For gorgeous coloring and showy flowers the Snapdragons ar especially desirable. Are easily raised from seed planted early. We have the popular colors, 18 to 20 inches tall varieties.

Fawn. Carmine-yellow.

Golden Queen. Clear yellow.

Rose Dore. Dark rose.

Fire Brand. A true bright scarlet.

Defiance. Arange-red.

Defiance. Orange-red.

Any of the above: Pkt. 10c; 1-8 oz. 25c

Semi-Dwarf. Mixed. Pkt. 10c; $1 / 4$ oz. 35c.

Tall Large Flowering. Especially for Greenhouse Culture-fine for outdoor planting.

Jennie Schneider. Salmon pink. Pkt. 25c.

Cheviot Maid. Clear pink. Pkt. 56c.

Silver Pink. Pearl pink. Pkt. 15c.

Rock's White. Pure white. Pkt. 25c.

For Snapdragon Plants, write for prices.

BACHELOR'S BUTTON (See Centaurea) BALSAM, LADY'S SLIPPER

Double-flowered, Mixed. Pkt. 10c; $1 / 4$ oz. 25c; oz. 60c BEANS, SCARLET'RUNNER

Climber. Pkt. 5c; 2 ozs. 10c; $1 / 4$ Ib. 25c; $1 / 2$ Ib. 25c; Ib. $45 c$ BLUE BONNET (See Lupins)

\section{CACALIA}

Tassel Flower (Flora's Paint Brush). Each blossom is a miniature paint brush, usually scarlet, a few come orange color; they make an excellent cut flower. Pkt. 10c; $1 / 4$ oz. 25c.

CALENDULA (Pot Marigold)

Double, Mixed. Shades of yellow and orange. Pkt. 5c; $1 / 2 \mathbf{o z}$ $15 \mathrm{c} ; \mathrm{oz} .25 \mathrm{c}$

Orange King. Glowing orange color. Pkt. 10c; 1/4 oz. 15c. Lemon Queen. Sulphur-yellow color. Pkt. 10c; $1 / 4$ oz. 15c.

Ball's Supreme. Orange with dark center. Pkt. 25c.

The Ball. Orange with light center. Pkt. 25c.

Sensation. Pure orange. Pkt. 50c.

Ball's Golden Improved. Golden-yellow. Pkt. 25c.

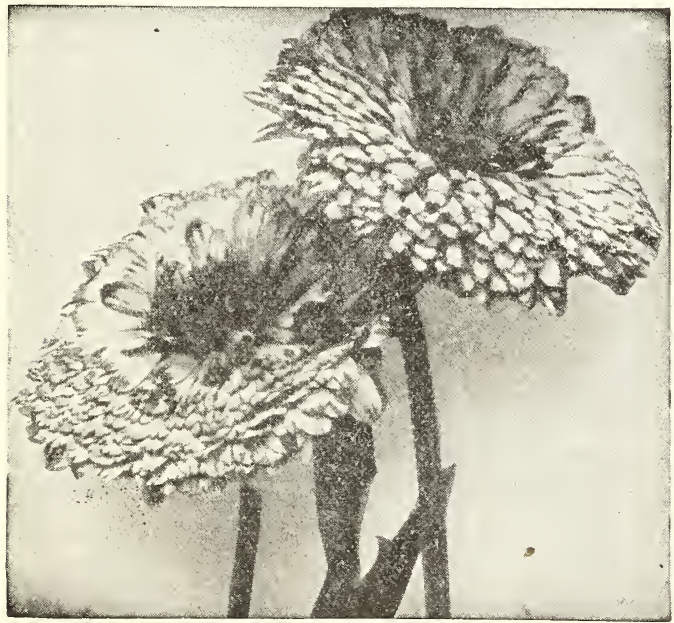

Calendula (Double Mixed)

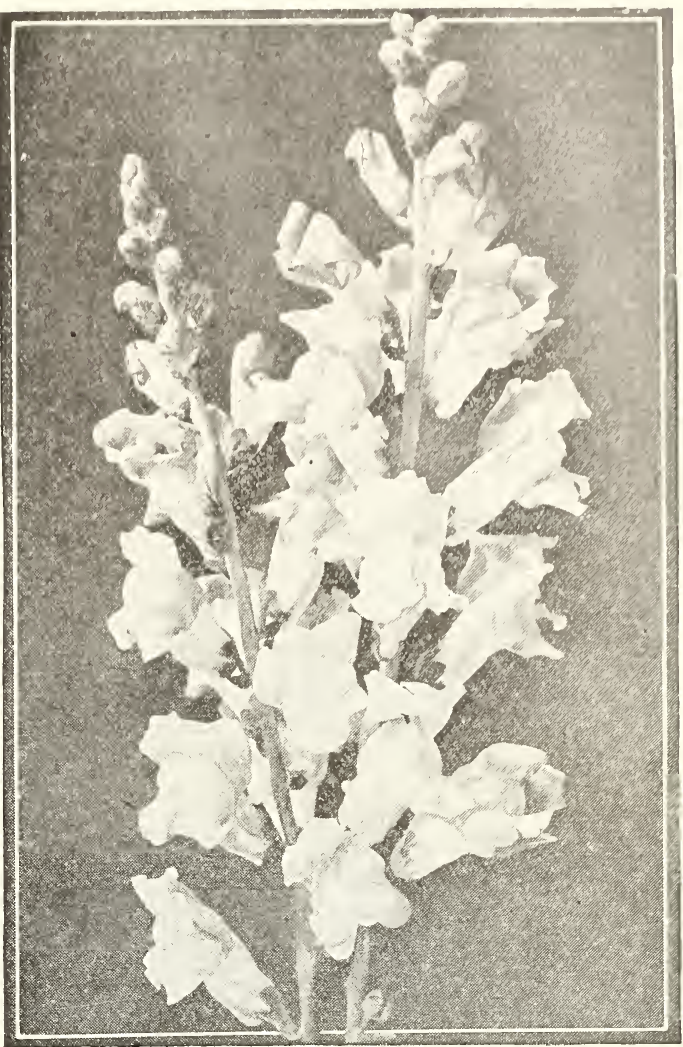

Antirrhinum (Snapdragon)

CALIFORNIA POPPY (Eschscholtzia)

Mixed. Orange, yellow, white. Pkt. 5c; oz. 25c;1/4 Ib. 75c.

Crimson. Pkt. 10c; $1 / 4$ oz. 25c.

The True California Poppy. A beautiful orange color. One foot high. Pkt. 10c; $1 / 2$ oz. 25c; oz. $40 \mathrm{c}$.

The Geisha. Brilliant gold inside, orange-crimson outside. Fluted petals. Pkt. 15c.

Fringed Yellow. Buttercup-yellow with fringed petals. Pkt. $10 \mathrm{c}$.

Annual. Mixed of bright colors. Pkt. 10c; $1 / 4$ oz, 15c; oz. 40c. CANARY BIRD VINE.

Annual. 15 to 20 feet. Clean, handsome foliage, with an Annual. 15 to 20 feet. Clean, handsome foliage, with an
abundance of bright canary-yellow blossoms; resembling canaries. Pkt. 10c; $1 / 4$ ox. 20c.

\section{CANDYTUFT}

Among the best for edging and bedding and for cutting. Use rich soil and water freely. Hardy and easy to grow. Good for cut flowers and borders.

Giant Empress. Hyacinth-flowered, large, pure white; a very select strain. Pkt. 10c; $1 / 4$ oz. $20 \mathrm{c} ;$ oz. $60 \mathrm{c}$.

Dwarf Hybrids. Mixed. Pkt. $10 \mathrm{c} ; 1 / 4$ oz. $20 \mathrm{c} ;$ oz. $60 \mathrm{c}$.

All colors mixed. Pkt. $10 \mathrm{c} ; 1 / 20 \mathrm{oz}, 15 \mathrm{c} ; 0 \mathrm{z} .25 \mathrm{c}$. CANNA

Crozy Hybrids. Start seed very early. Pkt. 10c; 1/1 oz. 15c For Camna Bulbs, see page 17.

CARDINAL CLIMBER child's Jewel Vine)

Attractive rapid climber, fern-like foliage, red morning glory like flowers. Pkt. 15c; 1-8 oz. 50 c.

\section{CASTOR BEANS}

Sanguineus, Green leaves, red stem. 6 feet. Pkt. 10c; oz. 20c. $1 / 4$ Ib. $50 \mathrm{c}$.

Zanzibariensis. Very ornamental. 10 feet. Pkt. 10c; oz. 25c ; $1 / 4$ Ib. 60 c.

CATCHFLY

Sillene Armeria. A showy annual producing head

and red flowers. Pkt. $10 \mathrm{c} ; 1 / 2$ oz. $20 \mathrm{c} ;$ oz. $35 \mathrm{c}$

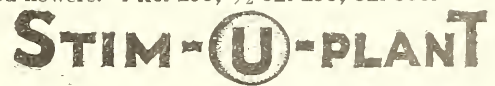

MAKES FLOWERS GROW

15c; 25c and 75c Packages, Postpaid 
Ponular annuals, easy culture, producing large ornamental comb-like heads, like ruffled chenille. Good for pots or flower beds.

Chrysantheflora. Compact, round heads of flowers in many colors. Pkt. 10c.

Cristata. Tall mixed. 18 inches. Pkt. 10c; $1 / 4$ oz. 25c.

Plumosa. $21 \%$ feet. Feathered or plumed varieties. Mixed. Pkt. 10c $1 / 4$ oz. 25c.

\section{Under this name is included CENTAUREA} Sweet Sultans, etc. They are favorites in all sections of the country, are demand as cut flowers.

Centaurea Cyanus (Bachelor's Button) Single and double mixed. Pkt. 10c; $1 / 1$ oz. 15c; oz. 40c.

Cornflower (Emperor William). Double blue. Pkt. 10c; $1 / 4$ oz. 20c oz. $60 \mathrm{c}$.

Candidissima. Silver-white leaves. Pkt. 10c.

Gymnocarpa (Dusty Miller). Foliage finely cut of silver gray. Pkt.10c. Imperialis (Giant Sweet Sultan)

Lavender (deep). White. Yellow. Rose.

Each of the above: Pkt. 10c; $1 / 4$ oz. 25c. All colors, mixed: Pkt. $10 \mathrm{c} ; 1 / \mathrm{oz}, 20 \mathrm{c} ; 0 \mathrm{z}, 65 \mathrm{c}$.

Sweet Sultan. Irixed colors. Pkt. 10c; 1-8 oz. 20c; 1/4 oz. 35c. CHINESE FORGET-ME-NOT

A lovely plant, 18 to 24 inches tall with flowers of a true Forget-MeNot blue. Makes good cut flowers. Tender perennial. Pkt. 25c. CHINESE LANTERN PLANT (Physalis)

Balloon, orange-scarlet color seed pods. Is a perennial blooming first season. Pkt. 15c. Plants are listed on page 11. CHINESE WOOLFLOWER

Produces numerous balls resembling red and pink balls of wool; wonerfully showy flower. Pkt. 10c.

\section{CHRYSANTHEMUMS}

Annual, single and semi-double, mixed. Pkt. 5c; $1 / 1$ oz. 15c; oz. 50c. CINERARIA MARITIMA

Mis-called by some as Dusty Miller. White-leaved. Pkt. 10c.

CLARKIA
Elegans. Rose, white, pink, all mixed. Pkt. 10c; $1 / 4$ oz. 20c.

CLIMBERS (Surprise Collection)

Mixed Annuals, many kinds. Pkt. 5c; $1 / 2$ oz. 15c; oz. 25c. CLEOME (Spider Plant)

Rocky Mountain Bee Plant. Cultivated extensively for bees. Pkt. 5c;0z. 20c; $1 / 4$ Ib. 60 c.

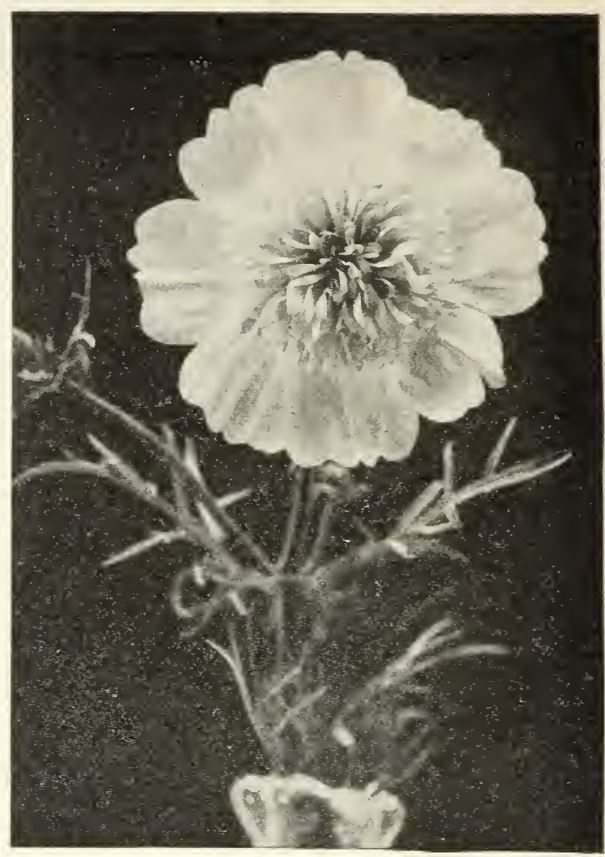

Cosmos (Double-Crested)

\section{COBAEA SCANDENS}

A tender perennial climber, purple, bell-shaped flower. Pkt. 10c $1 / 4$ oz. 25c.

\section{соскSсомв (See Celosia)}

\section{Cosmos}

A gorgeous, tall-growing annual, bearing its thousands of graceful flowers during the latter part of the summer and fall till frost. Its large single, pink, crimson or white flowers waving on their long stems amidst single, pink, crimson or white fowers waving on their long stems amidst the finely cut foliage are a lovely sight, and few plants are equally valuable admirable for hiding unsightly fences. Seed should be sown in open ground in early May or may be started in coldframes and transplanted to the open. We recommend for Denver the Early Flowering, in separate colors, which bloom from seed in 60 to 70 days, averaging 3 to $31 / 2$ inche in diameter.

Early Flowering, White

\section{Early Flowering, Crimson}

Any of the Above: Separate. Pkt. 10c; $1 / 1$ oz. 20c; oz. 60c.

Early Flowering. Mixed. Large varieties, 5c; $1 / 4$ oz. 15c; oz. 50c; $1 / 4$ lb. $\$ 1.25$.

Cosmos (Giant Late Flowering). Mixed. Pkt. 5c; oz. 30c; $1 / 4$ Ib. 75c Cosmos (Double-Crested). This is wonderfully beautiful, being sort of semi-double. Mixed. Pkt. 15c; $1 / 4$ oz. 50c.

\section{CYPRESS VINE}

Graceful climber fernlike foliage and a profusion of star-shaped flowers. Pkt. 10c; $1 / 4$ oz. 20c; oz. 60c.

But few people know Dahlias can be raised from seed and will bloom the first year. New varieties are obtained from seed.

All kinds, mixed. Pkt. $10 \mathrm{c} ; 1-8$ oz. $50 \mathrm{c}$.

For Dahlia Roots, see pages 19,20 and 21.

African Daisy (Dimorphotheca). 1 foot. Orange color, with brown eye single. Pkt. 10c; $1 / 4$ cz. 35c.

Arctotis Grandis. A type of African daisy, producing pure white blossoms, the reverse side being pale blue. Good cut flower. Pkt. 10c; $1 / 1$ oz. 25c.

Bellis Perennis, or English Daisy. See page 10

Painted Daisy (Pyrethrum Roseum). See page 10.

Paris (Marguerite). Large, single white. Pkt. 10c; 1-8 oz. 20c. DIDISCUS (Blue Lace Flower)

Has pale lavender blossoms; excellent cut flower. Pkt. 15c; 1-8 oz. $50 \mathrm{c}$

\section{See California Poppy}

\section{EÜPHORBIA VARIEGATA}

Snow on the Mountain. Very showy foliage, being white and green. Pkt. 10c; 1-8 oz. 20c

\section{EVERLASTING FLOWERS}

Many kinds, mixed. Pkt. 10c; 1//4oz. 25c.

FEVERFEW (Matricaria)

Half-hardy Perenial, white, double. Pkt. 10c; 1/4 oz. 20c; 0z, 60c FOUR O'CLOCK (Marvel of Peru)

Mixed, all colors. Pkt. 5c; $1 / 2$ oz. 15c; oz. 25c. OZ. $15 \mathrm{C}$

One foot; mixed colors; good for cutting; prolific bloomer. Pkt. 5c; $1 / 2$ oz. 15c; oz. 25c.

\section{GODETIA}

Attractive annuals growing 18 inches high. Particularly useful because they thrive in shady places where so few really fine flowers can be grown.

Mixed colors. Pkt. 10c; $1 / 4$ oz. 20c. 
Dipper (Calabash). Makes excellent dipper. Pkt. 5c; oz. 25c. Nest Egg (Japanese). Can use as nest eggs. Pkt. 5c; oz. 25c.

Hercules, Club (Guinca Bean). 3 to 4 feet long. Pkt. 5c; oz. 25c

Hercules'club (crer

Migar. Arough. $1 / 1 / \mathrm{Ib}$. $75 \mathrm{c}$.

Elegans (Angel's Breath). Annual, for bouquets. Pkt. 5c; 1.1 oz. 15c; oz. $50 \mathrm{c}$.

\section{HELICHRYSUM (Strawflower)}

One of the most popular everlasting.flowers. Used so much for permanen decorations. Easily grown. Our seed is from grower in California.

Silver Ball. A glossy white. Rose Carmine. Rose shades.

Fireball. Bright red. $\quad$ Canary-Yellow.

Each of the above: Pkt. 10c; $1 / 1$ oz. $30 \mathrm{c}$

Each of the above: Pkt. 10c; $1 / 20 z$. 30c. $10 \mathrm{c} ; 1 /$ oz. 25c.

Grown Mixed. Includes many colors. Pkt.

A universal favorite on account of its delightful fragrance and duration of bloom, flowering equally well as bedding plants in summer or as pot plants in the house during the winter. Tender perennial, blooming first year; mixed colors. Pkt. 10c; 1-8 oz. 60c.

\section{HYACINTH BEAN}

Tender, ornamental climber, mixed. Pkt. 5c; oz, 20c.

$$
\text { ICE PLANT }
$$

Foliage very ornamental, being covered with ice-like globules, and prized for garnishing; a valuable plant for dry, sunny situations on banks rockwork, old walls and ruins, etc., also for sunny borders. Very dwarf. Pkt. $10 \mathrm{c} ; 1 / 4$ oz. $20 \mathrm{c}$.

\section{JAPANESE HOPS}

Variegated foliage, vigorous climber, self-sows. Pkt. 10c; $1 / 4 \mathbf{~ o z . ~ 2 0 c ; ~}$ oz. 60c.

\section{JOB'S TEARS}

An ornamental grass. Pkt. 5c; oz. 15c; $1 / 4$ lb. 45c. KOCHIA (Childsii)

Also known as Mexican Burning Bush, or Giant Summer Cypress. Pkt. 5c; $1 / 2$ oz. 15c;0z. 25c

\section{KUDZU VINE}

This popular climber is easily propagated from seed. It is also cultivated as a forage crop. Especially to feed rabbits. Our seed is true Japanese. Pkt. 10c; oz. 40c; $1 / 4$ Ib. $\$ 1.25$; Ib. $\$ 4.00$.

\section{LANTANA}

Hybrida, Mixed. 2 feet. Shrubbery plant with Verbena-like flowers in shades of white, red and yellow. May be grown in pots or set out in summer. Pkt. 10c; 1-8 oz. 25c

\section{LARKSPUR}

Annual, double tall branching, mixed. Pkt. 10c; $1 / 4$ oz. 20 c; oz. $60 \mathrm{c}$.

Exquisite Pink Improved. A beautiful soft pink. Pkt. 15c.

Dark Blue. Pkt. 10c. Rose. Pkt. 15c

Lilac. Pkt. 10c. Sky Blue. Pkt. 10c.

Scarlet Flax. Brilliant colors, 20 to 24 inches. Pkt. 5c; $1 / 4$ oz. 15c.

\section{LOBELIA}

Crystal Palace. Dwarf, compact, dark blue. For baskets, porch boxes and borders, dark foliage. Pkt. 10c; 1-8 oz. 50c.

Emperor William. Light blue, green foliage, very compact, Emperor William, Light blue,

Gracilis. Trailing, dark blue, for hanging baskets. Pkt. 10c; $1-8$ oz. $40 \mathrm{c}$.

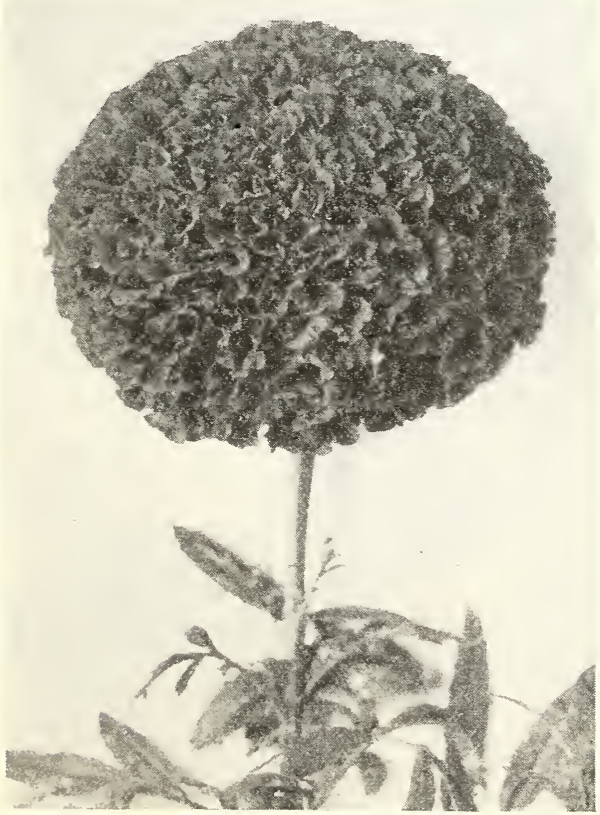

Marigold, Double Tall African

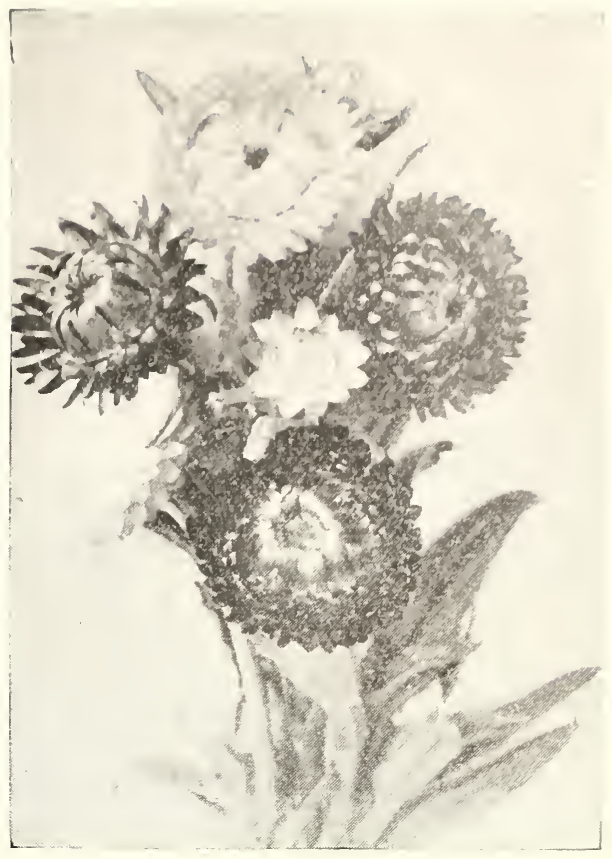

Helichrysum (Strawflower)

\section{LUPINS}

Annual Mixed. Stately Lupins give a rich and gorgeous effect graceful, long spikes, flowering from June until August. Pkt. $10 \mathrm{c}$; oz. $30 \mathrm{c}$.

Texas Blue Bonnet (Lupinus Texensis). Texas State flower, 12 inches. Dark blue flower tinged with white. Seeds are very hard; is best to soak over night before planting. Pkt. 10c. MARIGOLDS (Tagetes)

Double, Tall African. Splendid, mixed. Pkt. 10c; $1 / 4$ oz. 20c; $1 / 2$ oz. 35c.

Dwarf French. Double, mixed; strong colors. Pkt. 10c; $1 / 4 \mathbf{~ o z}$. 20c; $1 / 2$ oz. $35 c$.

(Musk Plant)

Tender perennial; tiny yellow flowers. Pkt. 20c

Tender climber for window boxes, mixed colors.

Pkt. 10c ; 1-8 oz. $40 \mathrm{c}$.

\section{MIGNONETTE}

Machet. Ever-blooming, best variety. Pkt. 10c; $1 / 1$ oz. 20 c; 1 oz. 60c. Dobbies' Red (Improved Golden Queen) A giant red. Pkt. 5c; $1 / 1 / 1$ oz. $15 c ; 0 z .40 c$

Grandiflora, Sweet (Reseda Odorata). Pkt. 5c; 0z. 20c; $1 / 4$ Ib. 60c. MOMORDICA (Balsam Apple)

Round a pple-shaped fruit, fine climber for trellis, stumps, etc. Pkt. 10c. MOONFLOWER

Tender climber, white. Pkt. 10c; $1 / 4$ oz. 30c; oz. 50c. MORNING GLORY

Tall. Mixed. Pkt. 5c; ox, 15c; $1 / 1$ lb. 50c; Ib. $\$ 1.35$.

Dwarf. Mixed colors. Pkt. 5c; oz. 20c; $1 / 4$ lb. $60 \mathrm{c}$.

Imperialis (True Japanese). Fringed, large, mixed. Pkt. 10c; $1 / 2$ oz. $25 \mathrm{c} ; 0 \mathrm{z} .40 \mathrm{c}$.

Ipomoea (Heavenly Blue). Immense flower of bright sky-blue in early morning. Blooms in August. A companion to moonflower, which is evening bloomer. Pkt. 15c; $1 / 4$ oz. $35 \mathrm{c} ; \mathbf{c z}$. $\$ 1.00$.

Clarke's Mammoth Blue. Described and illustrated on page 4. Pkt. 15c; 2 pkts. for $25 \mathrm{c}$

\section{NASTURTIUMS}

The varieties offered below have been selected with great care from very large variety of sorts as being the best and most distinct. DWARF OR TOM THUMB

Are especially suited for bedding, and when planted in rows will make beautiful sight when in bloom.

Dwarf Varieties, Mixed. "Dependable Grade." Pkt. 5c; $1 / 2$ ox. 10c; oz. 15c; 2 oz. pkg. 25c; $1 / 4$ Ib. $45 \mathrm{c} ; 1 / 2$ Ib. $75 \mathrm{c} ;$ lb. $\$ 1.40$. NASTURTIUMS-TALL-Giant-Flowered

Tall varieties should be trained to climb fence, strings or trellis, growing 6 to 10 feet. Our stock is superb and includes some Madam Gunter

varieties.

Tall Varieties, Mixed. "Dependable Grade." Pkt. 5c;
ox. 15c; 2 oz. pkg. 25c; $1 / 4$ Ib. 45c; $1 / 2$ Ib. 70c; Ib. $\$ 1.25$.

Sander's Hybridia. Mixed colors. Deliciously fragrant. Pkt. 10c

NIGELIA (Love-in-the-Mist)
Mixture of blue and white. PKt. $5 \mathrm{c}$; $1 / 2$ oz. 15c.
ORNAMENTAL GRASSES

Eulalia Japonica Variegata. Narrow striped leaves, feathery plumes. Pkt. 10c; $1 / 4$ oz. 25c.

Special Mixture. Many kinds mixed by us. Pkt. 10c; 1/ oz. 20c. PASSION FLOWER

A beautiful tender climber, sky-blue. Pkt. 10c; 1-8 oz. 40c. 


\section{PANSIES}

Favorites with all. For best results you must start with a good strain. The finest Pansies are, as a rule, shy seeders, which accounts for the difference in the price of the various mixtures offered.

Spring Planting. Seed should be sown in hotbeds or boxes, then transplanted to open ground after freezing is over.

As soon as the plants are up and large enough to handle, they should be thinned out or transplanted to stand 9 inches apart in the rows. Thorough cultivation should be given from the start, as Pansies will not thrive when obliged to share the beds with a mass of weeds. It is a mistake to plant Pansies in the shade of a tree or building. During dry weather the bed should be watered daily, and in extreme cases twice a day for the best results. Leaflet free upon request, Pansy Culture.

Fall Planting. Many gardeners prefer August sowing in hotbeds and besides the sash, covering well with straw, mulching with manure when winter sets in. Gradually uncovering on warm days in early spring. These will produce the early April blossoms.

Pansies are successfully grown from seed even by the novice; however, wecommend our full-blooming plants. Ready in April.

Pansy Plants, see page 17.

Giant Trimardeau. The Giant-Flowering varieties are best for genera bedding, are most hardy and bloom early and late. English-grown seed, separate colors.

King of Blacks. Jet black.

Snow Bird. Pure white.

Giant Purple. Purple.

Prince Bismarck. Bronze.

Emperor william. Blue.

Golden-Yellow.

Any of the Above: Pkt. 10c; $1-8$ oz. $50 \mathrm{c}$; oz. $\$ 2.25$.

\section{PANSY COLLECTION}

One packet each of the above six separate colors. $50 \mathrm{c}$.

Giant Trimardeau. Mixed. Pkt. $10 \mathrm{c} ; 1-8$ oz. $40 \mathrm{c} ;$ oz. $\$ 1.50$

Good Mixed. Pkt. $10 \mathrm{c} ; 1-8$ oz. $30 \mathrm{c} ; 1 / 4$ oz. $5 \mathrm{Cc}$; $0 \mathrm{z}$. $\$ 1.25$.

Denver Giants. A grand assortment of colors, many with remarkable

markings all of which are truly giants, some being three inches in di-

ameter. This is the best strain that we have ever seen. Pkt. 25c; 1-8 oz. $\$ 1.35 ; 1 / 4$ oz. $\$ 2.50$.

"Dependable Grade" "Mixture. A good second grade of Denver Giants. Pkt. 20c.

Tufted Parsies (English Viola Cornuta). See sage 12.

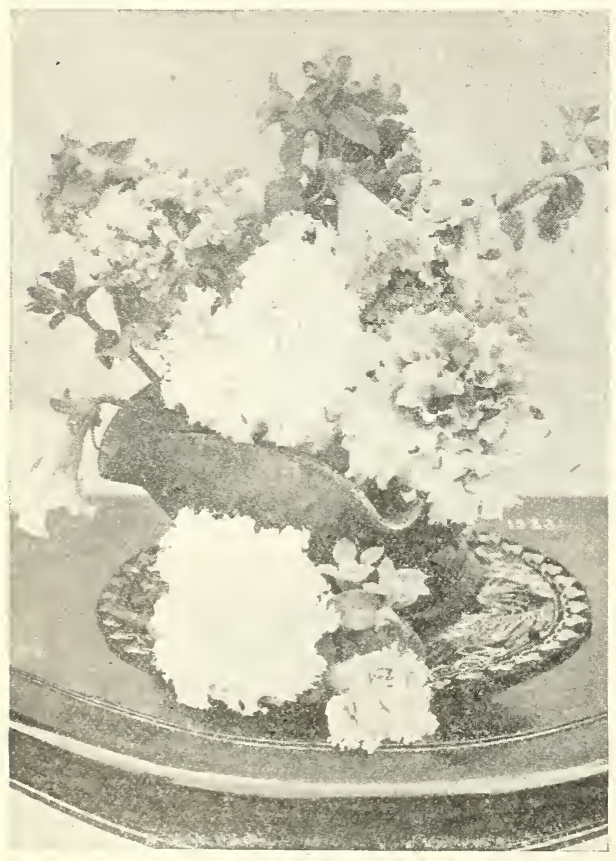

Double Fringed Petunia (The all-purpose Favorites)

\section{PHLOX DRUMMONDII}

Grandiflora. Mixed. Pkt. 10 c; 1-8 oz. 25c; oz. \$1.25.

Star of Quedlinburg. Fringed, mixed. Pkt. 10c; 1-8 oz. 25c; oz. \$1.25. For Hardy Phlox Roots, see page 13.

\section{POPPIES}

The popularity of the Poppy is greater every year, and when one has seen them blooming in masses, with their large, brilliantly colored flowers wide open in the glaring sun, one cannot help but admire them.

Single Mixed. Many varieties. Pkt. 5c; oz. 20c; 1/4 Ib. 50c.

Double Mixed. Includes many popular varieties. Pkt. 5c; oz, 20c; 1/4 Ib. 65c; Ib. $\$ 2.00$

Shirley. Single, large, many shades of rose and red. Pkt. 10c; oz. 30c.

Tulip Poppy. In size like a large red tulip, glowing scarlet. Pkt. 10c; $1 / \mathbf{4}$ oz. $20 \mathrm{c} ; 0 \mathrm{z} .60 \mathrm{c}$.

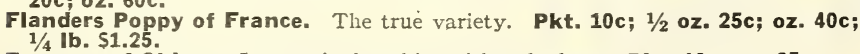

Empress of China. Large, single, white with red edges. Pkt. 10c; oz. 25c. For Hardy Poppy Seed, see page 10. Plants, page 13. the weather has settled. season.

eddewigii. Sin-

gle and double.

mixed by us.

25c; oz. $80 \mathrm{c}$

aciniatus. Large

single-fringed

10c; $1 / 4$ oz. 20c

oz. $60 \mathrm{c}$.

For Hardy Garden Pink Seed, ennials, page 10

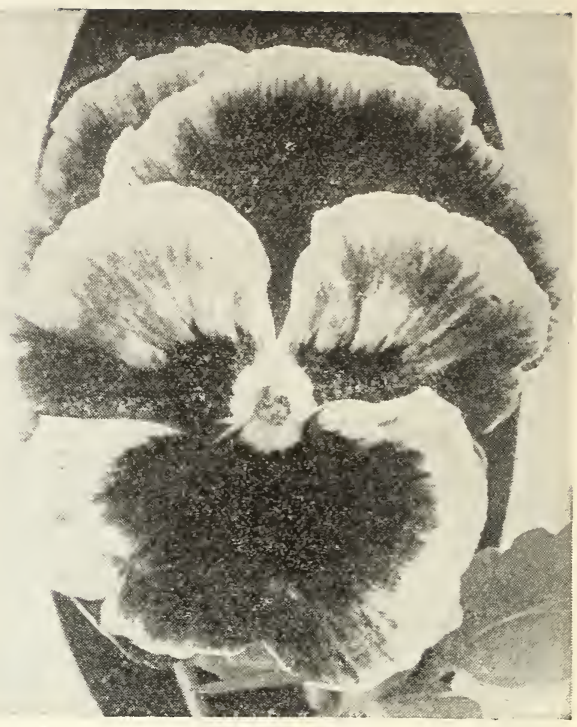

Denver Giant Pansy

\section{PETUNIAS}

arden without these favorites could hardly be called complete destroyed by frost. Their culture is the most simple; any soil seems to suit them, while, of course, a good rich earth adds greatly to the richness of ists, and we are confident that they will give satisfactory results. For early blooming sow early in the house and cultivate in small pots or flats Giants of California. Large, single, many colors, mixed. Pkt. $35 \mathrm{c}$ (Fingle "Fluffy Ruffle." Imported English seed. Pkt. 50c.

iant Double Fringed. producing a very high percentage of large full double flowers. Pkt. \$1.00.

\section{DWARF PETUNIAS}

Blue blossom with white center. Pkt. 15c; 1-8 oz. 50c.

Silver Blue. Light Blue. Pkt. 25c

Snowball. Pure white, very compact Pkt, 15c;1-8 oz. 50c.

With some straw or leaf protection many Pinks live over to bloom the Usually lives over. Pkt, 15c 
PORTUlacA, ROSE MOSS (Sun Plant)

Double Mixed. Pkt. 10c; 1-8 oz. 50c; oz. \$2.25.

Single Mixed. Pkt. $10 \mathrm{c} ; 1 / 4$ oz. $25 \mathrm{c} ; 0 \mathrm{z} .75 \mathrm{c}$.

SALPIGLOSSIS, VELVET FLOWER
SAR

One of the very charming, quick-growing garden flower.

One of the very charming, quick-growing garden flowery.

fully veined varieties. Pkt. 10c; 1-8 oz. 35c; 1/4 oz. 60c.

Splendens. Scarlet. $2 \frac{1}{2}$ feet. Pkt. 15c; $1-8$ oz. 60c; $1 / 4$ oz. $\$ 1.00$.

Clara Bedman or Bonfire. New early dwarf 18 to 20 inches. Pkt. 15c; 1-8 oz. 75c.

Farinacea (Mealy Sage). Light blue or silvery-lavender

Pkt. 15c.

SCABIOSA (Pincushion Plant, also Mourning Bride)

Azure Fairy. A beautiful lavender-blue. Double. Pkt. 10c.

Crimson. A strong color.

Peach Blossom. Pink.

Shasta. Pure white, enormous size

Each of the above: Pkt. 10c; $1 / 8$ oz. 20c.

Double Mixed. Pkt. 10c; $1 / 4$ oz. 15c; oz. 50c. SCHIZANTHUS (The Poor Man's Orchid)

Small butterfly-like flowers of very brilliant colors, mixed,

1 foot. Pkt. 10c; 1/4 oz. 25c.

Tender; leaves tremble when touched. Pkt. ;10c; 1/4 oz. 20c.

SHAMROCK
Grows plants quickly. Pkt. 10c.

A tender perennial climber, especially for conservatory. Pkt. 10c; $1 / 4$ oz. 25c.

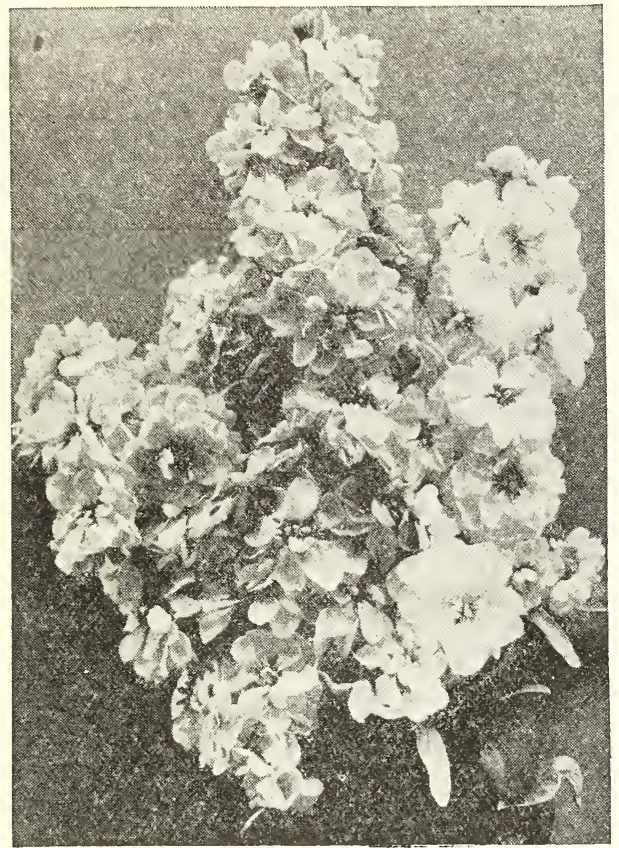

Stocks (Giant Perfection)

\section{SUNFLOWER}

Annual. Should be planted with discrimination in every garden

Fancy Double California. Dwarf; a beautiful yellow. Pkt. 5c; oz.

"Unique." 25 ;rown and red (Colorado origin). Pkt. 10c; 1/2 oz. 25c; oz. 40c.

Mammoth Russian. Oz. 5c; 1/4 lb, 10c; Ib. 25c.

SWEET SULTAN (Centaurea Maschata) (See Centaurea) THUNBERGIA (Climbing Black-Eyed Susan)

Beautiful, rapid-growing annual climbers, prefer a warm sunny situation; used extensively in hanging baskets, vases, low fences, etc.; very pretty flowers in buff, white, orange, etc., with dark eyes. Pkt. 10c; 1-8 oz. 30c.

Our Mammoths are truly large and beautiful. The following named varieties are furnished separate:

Purple. Dark purple.

Pink. Mammoth.

Blue, Dark.

Any of the above separate colors: Pkt. $10 \mathrm{c} ; 1-8 \mathrm{oz} .25 \mathrm{c}$.

Mixture of Mammoth Varieties. Mixed by grower. Pkt. 10c; 1/4 oz. 40c; oz. \$1.25. For Verbena Plants, write for prices. WALLFLOWER

Double. Very fragrant. Mixed. English seed. Pkt. 15c.

Single. Mixed colors. Pkt. 10c; $1 / 4$ oz. 25c.

WILD CUCUMBER

Vigorous climber; self-sows. Pkt. 10c; oz. 25c; 1/4 lb. 75c

$$
\text { ZEA JAPONICA }
$$

Rainbow Corn. Grows about 4 feet tall, like grass, with leaves striped in yellow, green and rose. Pkt. 10c.

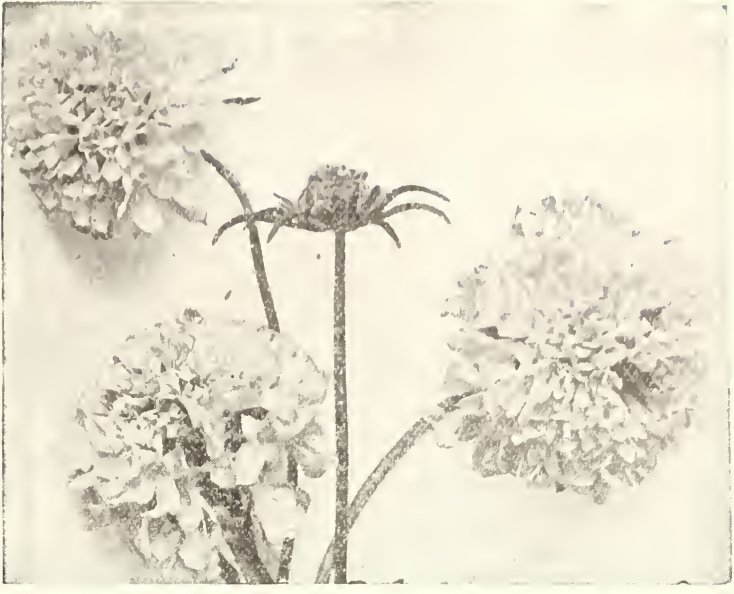

Scabiosa (Pincushion Plant, also Mourning Brida,

STATICE

Especially desirable for use in bouquets.

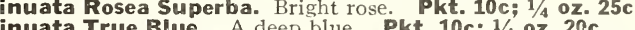

\section{STEVIA SERRATA}

Bearing numerous pure white flowers, very suitable to use in bouquets.

STOCKS (Ten Weeks) (Gilliflower) of bloom, it is unsurpassed. Pkt. 15c; $1 / 4$ oz. 65c.

Brillant-Come-Again."

Creole. Canary-yellow. Pkt. 25

(White. Pkt. 25c.

STRAWFLOWERS

akes attractive background in a garden. Pkt. 10 c; 1/4 oz. 25c.

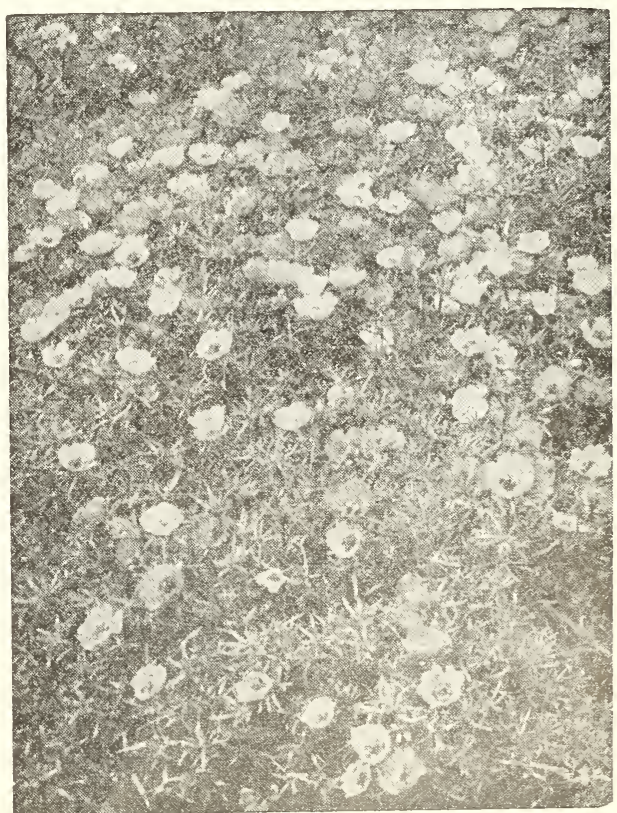

Portulaca (Rose Moss) Single 


\section{Perenniai Flower Seeds}

All Postpaid

\section{Perennial Plants on pages 11 to 16, inclusive}

We advise planting liberally of this class of flowers. They practically take care of themselves. All are hardy in Colorado except where sn stated. A very few are Biennials-bloom in the second season and then die. Several tender Perennials that bloom the first year by starting indoors are listed with Annuals. Campanulas and Digitalis are in this list; however they are classed as Biennials.

SEED NOTES * Indicates varieties that planted in summer of one scason will usually

bloom the following summer.
†Requires the third season for blooming. Cultural leaflet, Perennlals, free upon request.

Ampelopsis Quinquifolia (IVoodbine Climber). Easily propagated. Pkt. 10c; oz. 25c.

Campanula (Canterbury Bell). Make beautiful cut flowers and very decorative. We have

a splendid assortment. In some localities biennial.

*Media. Single, separate colors, white, blue and rose. Pkt. 10c.

6. Niedia. Single mixed colors. Pkt. 10c; 1-8 oz. 20c.

* Media. Double mixed, English-grown seed. Pkt. 10c; 1-8 oz. 35c.

Campanula, Calycanthema (Cup and Saucer). Separate colors. White, rose and blue. Fkt. 10c. Mixed. Pkt. 10c.

Carnation.

Double Aixed. Semi-tender. Pkt. 15c; 1-8 oz. 50c.

Burbank's Marguerite. Mixed, blooms first year, tender. Pkt. 15c; 1-8 oz. 40c.

†Columbine, Aquilegia Coerulea (Queen of Wild Flowers). The true grey-blue color,

mountain grown seed. Pkt. 15c; $1-8 \mathrm{oz}$. 35c; oz. $\$ 1.75 ; 1 / 4$ ib. $\$ 5.00$.

Columbine, California Hybrids. Mixed of grey, blue, yellow, etc. Pkt. 10c; 1-8 0z. 30c;

* Columbine, Long Spurred Hybrids. Very choice strain. Pkt. 15c.

*Coreopsis, Lanceolata, Grandifiora. Beautiful golden-yellow flowers; 2 feet. Pkt. 10c; $1 / 4$ oz. $20 \mathrm{c}$.

Daisy (Bellis Perennis). Double English.

Pink. Pkt. 10c; 1-8 oz. 50c. White. Pkt. 10c; 1-8 oz. 50c.

Mixed. Pkt. 10c; 1-8 oz. 40c.

*Daisy, Shasta. Alaska; very large white; blooms all summer. Pkt. 15c; 1-8 oz. 50c; oz. \$2.50.

Delphinium (Perennial Larkspur). This stately flower is the admiration of the flower garden. They are easily grown and sure to please.

*Belladonna. Light turquoise-blue, free bloomer. 2 feet. Pkt. $25 \mathrm{c} ; 1-8 \mathrm{oz}, 60 \mathrm{c}$.

*Bellamosum. Dark blue with white center. 3 to 4 feet. Pkt. 25c; 1-8 oz. 60c.

*Hybrids. Produces a grand assortment; some very beautiful combinations of colors of blues, whites, pinks, etc. Very desirable. Pkt. 25c: 1-8 oz. 60c.

*New Wrexham Hybrids (Hollyhock strain). A wonderfully beautiful strain; some double; some semi-double in different shades. Very fine. Pkt. 35c.

* Digitalis (Foxglove). Gloxiniaflora; pink, white and purple. 3 feet. Biennial. Seeds mixed. Pkt. $10 \mathrm{c} ; 1 / 4$ 0z. 30c; oz. $90 \mathrm{c}$. Forget-me-not. Myosotis. Dwarf, blue, tender. Pkt. 10c;1-8 oz. 25c.

Forget-me-not. New Rose. A very marked contrast to the blue. Pkt. 10c; 1-8 oz. $25 \mathrm{c}$.

* Gaillardia (Blanket Flower). Grandiflora, mixed colors. Pkt. $10 \mathrm{c} ; 1 / 4$ 0z. 25c; 0z. $75 \mathrm{c}$.

Geum. Free-flowering and attractive for the perennial border. Variety, Mrs. Bradshaw, double orange-scarlet flowers. Pkt. 25c.

* Gypsophila (Baby's Breath). Paniculata, everlasting. Pkt. $10 \mathrm{c} ; 1 / 402.30 \mathrm{c} ; 0 \mathrm{z}$. 90c.

*Double Blossom Baby Breath. White, Dreer's stock. Pkt. 25 c.

*Hollyhocks. Old-time favnrite that should have a place in every hardy border. We offer the celebrated Chater's English Double Hollyhocks; prize strain saved from the finest collection of magnificent double flowers. Blooms July and August. Height 5 to 7 feet.

Double White. Double Pink. Double Crimson. Double Maroon. Double Yellow.

Separate colors: Pkt. 10c; $1 / 4$ oz. 40c; 0z. \$1.25.

Double Mixed: Pkt. 10c; 1/4 oz. 35c; oz. \$1.00.

*Hollyhock (New Double Newport Pink). The grandest of pure pinks. A very exquisite shade. Pkt. 15c.

Lathyrus Latifolius. Hardy-flowering peas, growing on trellis, fence, etc. Mixed. Pkt. 10c; 1/4 oz. 25c; oz. 75c.

Lupinus (Polyphyllus). Easy growing border plant, producing stately spikes of bloom. Pkt. 10c.

* Pansy Violet (Viola Cornuta). English-tufted pansy. Very hardy and suitable for borders and bedding, blooming all summer. Fragrant. English seed; mixed. Pkt. 15c; 1-8 oz. 75c; oz. $\$ 3.00$

Pentstemon (Beard's Tongue). Bloom profusely during the summer; grand for color masses in hardy beds. Mixture of Gloxinia-shaped flowers, about 2 feet tall. Our new Hybrids produce many, shades. Pkt. 20c; 1-8 oz. 60c.

"Sensation." If seed is sown in heat in February or March, will blossom first year, producing large spikes of Gloxinia-like flowers in a wide range of bright colors. Pkt. 25c.

Phlox (Perennial Variety). Decussata, Mixed. Pkt. 20c.

Pinks, Hardy Garden. Grass pinks, also called June pinks, a special mixture. Pkt. 15c; $1 / 4$ oz. 50c; oz. $\$ 1.50$.

Crimson Bedder. Beautiful crimson. almost a carnation. Pkt. 15c.

Poppies. Large brilliant flowers, wide open in the glaring sun. Gorgeous.

*Orientale. Immense, large flaming scarlet. Very striking. Pkt. $10 \mathrm{c} ; 1 / 4$ 0z. 35c; 0z. $\$ 1.00$.

*Orlentale Hybrids. Single mixed. Pkt. 15c; 1-8 oz. 40c; oz. \$1.25.

izeland. Single, mixed of yellow, white, orange and scarlet. Iceland. Single, mixed of yellow,
Pkt. 15c; 1-8 oz. 35c: 0z. \$1.00.

Pyrethrum Roseum (Painted Daisy). Great value as cut flowers. lasting for days. Perfectly hardy. Easily grown, blooming early in summer.

Separate colors: pink, white and crimson. Each, pkt. 25c.

tStatice Latifolia (Sea Lavender). Dense panicles of lavenderblue flowers. Pkt. 10c; $1 / 4$ 0z. 50 ; oz. $\$ 1.50$.

* Sweet William. One of the showiest of all perennials.

Single and Double Mixed. A grand assortment. Pkt. 10c; $1 / 4$ oz. 25c; oz. 75c.

Newport Pink. A pink beauty. Pkt. 10c.

Verbena, Hardy Garden. Venosa. Grows about one foot high and blooms from early summer until late fall. Flowers a bright purplish-heliotrope. Pkt. 15c.

Violets. Sweet-scented. Easily grown from seed. Pkt. 15c; $1-8$ oz. $60 \mathrm{c}$; oz. $\$ 2.50$.

Cultural leaflet free upon request, Violet Culture, Indoors and Outdoors.

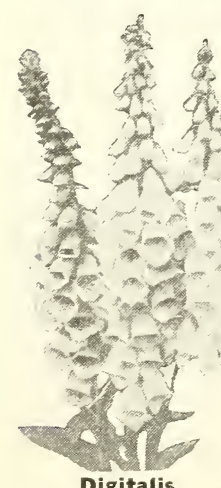

Digitalis

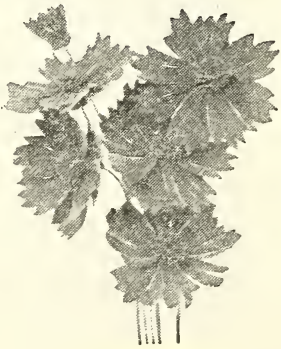

Coreopsis BETTER SEEDS MAKE BETTER GARDENS
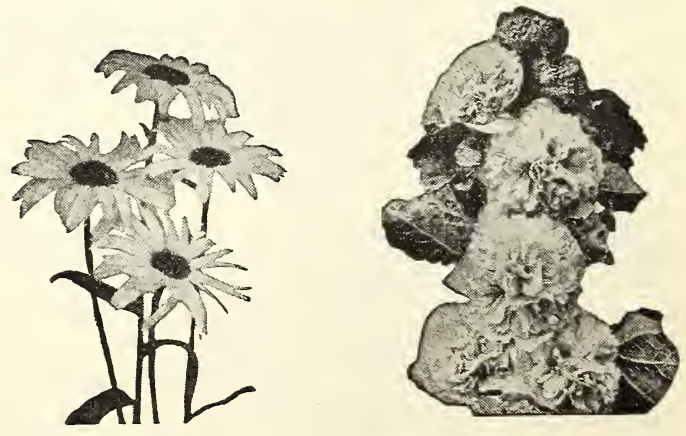

Double Hollyhock 


\section{Hardy Perennial Plants posTPAID}

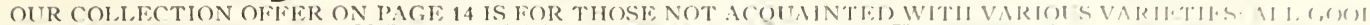

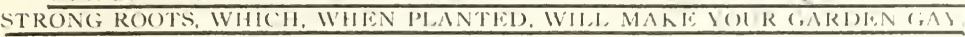

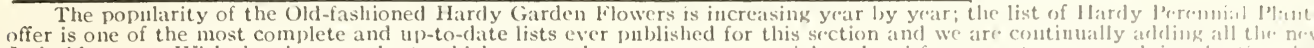

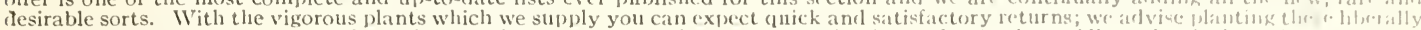

as they practically take care of themselves, and once established will increase in size and sulendor.

where so stated. A very few are Biennials-bloom in the second season, then die.

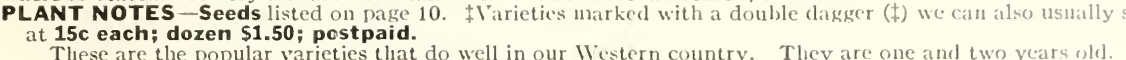

Cultural leatlet free on request, Perennials - Culture from seed and garden are one and two ycars ol

\section{ACHILLEA (The Peari)}

A hardy and vigorous grower, 18 to 24 inches tall, with numerous

small double-white flowers like rosettes, in clusters, blooming in July and

August. Good bouquet flower. $20 \mathrm{c}$ each; $\$ 2.00$ per doz. ACONITUM (Monkshood)

Fischeri. Large spikes of hood-shaped porcelain-blue flowers; a dwarf

variety, September; 2 feet tall. Each 35c; $\$ 3.50$ per doz. AMPELOPSIS

Quinquifolia (Woodbine Climber). Each 25c; 3 for 60c.

\section{ANCHUSA ITALICA}

Dropmore. A beautiful gentian-blue. Especially suitable for center of bed or back border. June to September. Each 20c; $\$ 2.00$ per doz. ASTERS (Michaelmas Daisies)

Called Fall Asters. Profuse, late bloomers.

Climax. Blue.

Miss Raynor. Crimson.

Lakeview. Pink.

Climax. IVhite.

20c each; $\$ 2.00$ per doz.

ARTEMISIA

Lactiflora. White flowers on strong stems; fragrant; good for cutting. 4 feet. September. Each 20c; $\$ 2.00$ per doz.

\section{BLEEDING HEARTS}

Dicentra Spectabilis. Drooping, heart-shaped flowers; especially useful for planting in the shade; come early in spring. Good roots, 60c each. BOLTONIA

Daisy-like flowers in great profusion. 6 feet tall. August and September. White and pink. Each 20c; $\$ 2.00$ per doz.

Small double-yellow flower. Each 15c; $\$ 1.50$ per doz.

\section{CAMPANULA (Canterbury Bell)}

Make beautiful cut flowers and very decorative. We have a splendid assortment. In some localities biennial. July.

Media Single. Large blue, pink and white, separate.

Media Double. Blue, pink and white, separate.

Cup and Saucer (Calycanthema). Blue, pink and white, separate. Each 20c; $\$ 2.00$ per doz.

\section{HARDY CARNATIONS}

A strain of medium size blossom; very suitable for outdoor culture. Each 20c; $\$ 2.00$ per doz.

\section{CENTAUREA MONTANA}

Perennial Cornflower. Blue. 2 feet. June to September. Price each 20c; $\$ 2.00$ per doz.

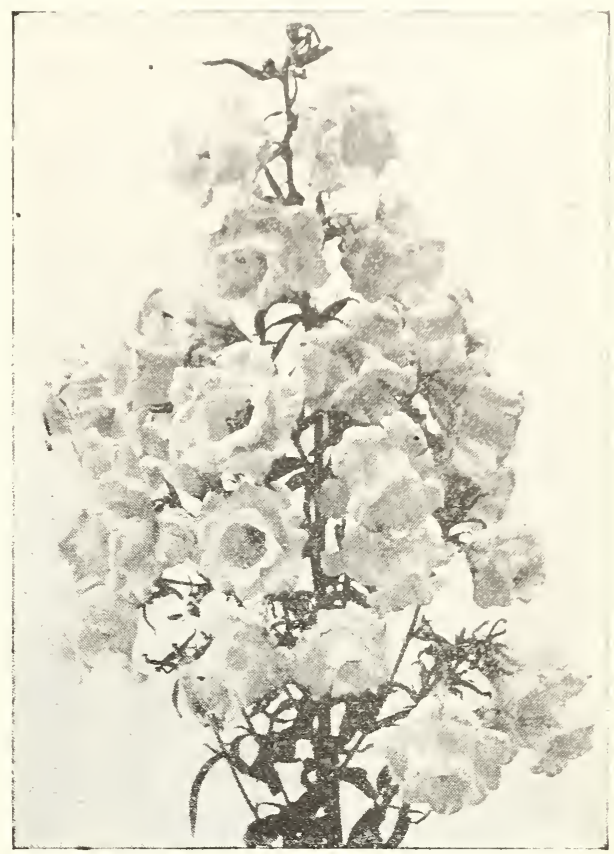

Campanula Calycanthema

CHINESE LANTERN PLANT Balloon, orange-colored seed pods; very handsome for winter bouquets. Each 20c; $\$ 2.00$ per doz. (For seeds see page per doz. (For seeds see page

\section{CHRYSANTHEMUMS}

†Old-fashioned, hardy, small,
double, white, pink, orange and yellow. Each 20c; \$2.00 per doz.

\section{COLUMBINE}

Aquilegia Coerulea (Queen of Wild Flowers). The true grey-blue color, mountaingrey-blue color, mountainroots, each 20c; $\$ 2.00$ per doz.

California Hybrids. Mixed of grey, blue, yellow, etc. Each $20 \mathrm{c} ; \$ 2.00$ per doz.

\section{COREOPSIS}

- Lanceolata Grandiflora. Beautiful golden-yellow flowers all summer; 2 feet. Each $20 \mathrm{c} ; \$ 2.00$ per doz.

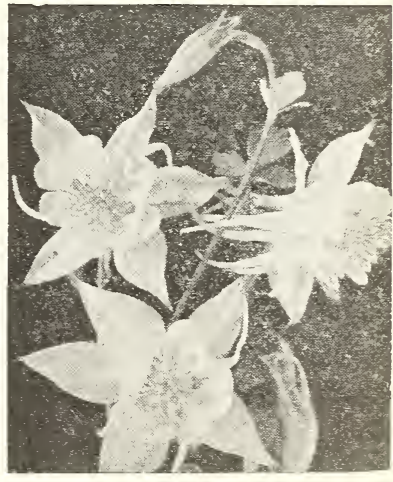

Columbine

DAISY (Shasta)

Alaska. Very large, white, blooms all summer. Each 20c; $\$ 2.00$ per doz.

\section{DAY LILY, FUNKIA}

Alba. The old-fashioned garden lily, Very large, pure white, fragrant flowers. Each 30 ; $\$ 3.00$ per doz.

\section{DELPHINIUM (Perennial Larkspur)}

This stately flower is the admiration of the flower garden. Belladonna. Light, turquoise-blue; free bloomer. 2 feet. $\$ 2.00$ per doz

Bellamosum. Dark blue with white center. 3 to 4 feet. $\$ 2.00$ per doz.

Chinese Album. White flower, more dwarf than above. $\$ 2.00$ per doz. 
GAILLARDIA (Blanket Flower)

† Grandiflora. Mixed of orange, red, brown and crimson. Masses of daisy-like flowers all summer. Each 20c; $\$ 2.00$ per doz.

\section{GEUM}

Double orange-scarlet flowers in abundance. Each 25c; $\$ 2.50$ per doz. GOLDENROD

Popular for background; grows 5 feet. Each 20c; $\$ 2.00$ per doz. HARDY FERNS

Everybody can have beautiful Ferns growing in their own yard in half-shady places and where other flowers have not done well.

We furnish from Minnesota by having mailed direct from grower to you, postpaid.

\section{HARDY FERNS FOR ONLY $\$ 5.00$, PREPAID}

8 Ostrich Plume, 8 Lady Ferns, 4 Sensitive

One-half assortment, 10 Ferns, for $\$ 3.00$; one-fourth assortment, 5 Ferns, for \$1.75. Any one Fern for $50 \mathrm{c}$

Special cultural leaflet mailed with Ferns.

\section{HARDY COLORADO NATIVE FERNS}

We supply from Denver, postpaid.

Aspidum Felix Mas. Gathered in mountains in Boulder county. Should be in every garden. Each $40 \mathrm{c} ; \$ 4.00$ per doz.

GYPSOPHILA (Baby Breath)

Paniculata. Everlasting. Each $20 \mathrm{c} ; \$ 2.00$ per doz.

Double Blossom Baby Breath. White. Dreer's stock. Grafted roots. Each $50 \mathrm{c} ; \$ 5.00$ per doz.

New Bristol Fairy. Early, large double, pure white. Produces second crop of spikes after the first have been cut. Strong roots. Each 60c; $\$ 6.00$ per doz.

\section{HELENIUM . (Sneezewort)}

Grows 6 to 7 feet. Very strong growth, with flower of golden-yellow, velvety-brown center. In August and September. Each 25c; $\mathbf{\$ 2 . 5 0}$ per d $\urcorner$ z.

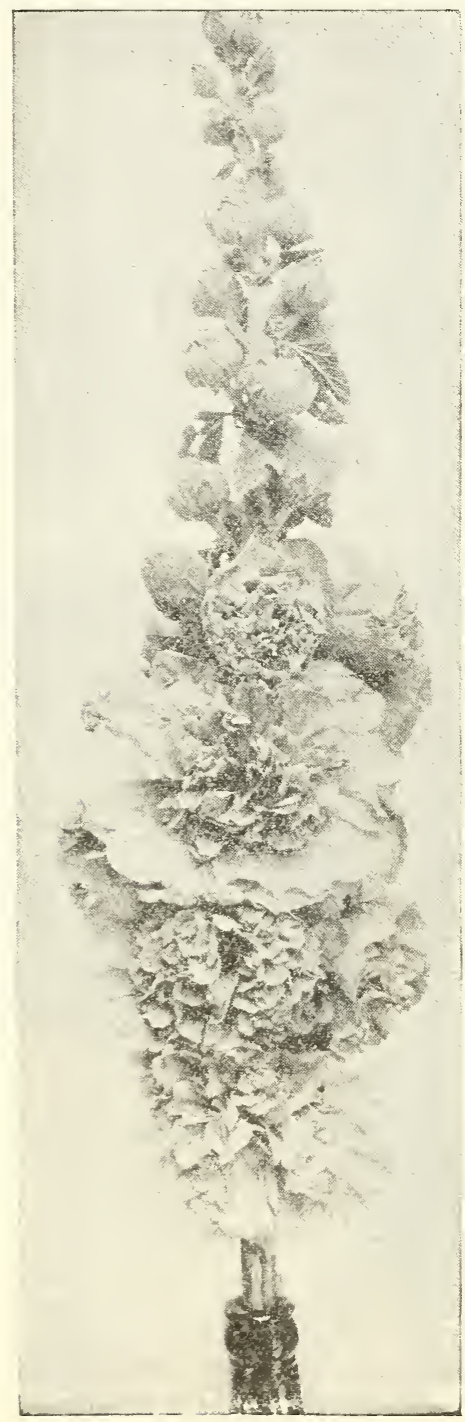

Hollyhock, Double Newport Pink
"Little Book of Perennials" by Hottes. Postpaid for $\$ \mathbf{1 . 5 0}$.

\section{HELIOPSIS}

Orange Sunflower. Flowers are a beautiful deep golden-yellow, 2 inches in diameter; grows 3 to 4 feet; blooms all summer. Each 20c; $\$ 2.00$ per doz.

HEMEROCALLIS

Fuiva (Orange Day Lily). Late. Each 15c; $\$ 1.50$ per doz.

Flava (Lemon or Yellow Day Lily). Early. Each 15c; $\$ 1.50$ per doz.

HIBISCUS (Rose Mallow)

Crimson eye, immense size flowers of pink, red and white with crimson in center; beautiful. Each 25c; $\$ 2.50$ per doz.

\section{HOLLYHOCKS}

Old-time favorites that should have a place in every hardy border. We offer the celebrated Chater's English Double Hollyhocks, prize strain saved from the finest collection of magnificent double flowers. Blooms July and August. Height 5 to 7 feet. Good one-year-old Roots, in separate Colors.

White Red Blush Yellow Black

Any of the Above: Each 20c; $\$ 2.00$ per doz.

\section{HOLLYHOCK, NEW}

Double Newport Pink. The grandest of pure pinks. A very exquisite shade. Each 25c; $\$ 2.50$ per doz.

LATHYRUS LATIFOLIA

Hardy flowering peas, mixed colors. Climbing, with dense foliage. Roots 25c $\$ 2.50$ per doz.

\section{LINUM}

Linum (Blue Flax). Pale blue flowers com pletely covering the plant: very attractive. 2 to 3 feet. Each 25c; $\$ 2.50$ per doz. LUPINUS

A good border plant. In blue, pink an white. Each 25c; $\$ 2.50$ per doz.

\section{LYCHNIS}

Rose Campion (Chalcedonica). Scarlet; feet. Each 20c; $\$ 2.00$ per doz. MONARDA DIDYMA

Bergamot (Horsemint). Scarlet; flowers all summer. Each 25c; $\$ 2.50$ per doz. MYRTLE

The old-fashioned garden variety. In clumps $25 \mathrm{c} ; \$ 2.50$ per doz.

\section{PANSY VIOLET (Viola Cornuta)}

English Tufted Pansy. Very hardy and suitable for borders and bedding, blooming all summer. Fragrant.

Light Blue Golden-Yellow Purple Sulphur-Yellow Glowing Violet-Purple Each 15c; $\$ 1.50$ per doz.

\section{PENTSTEMON}

Sonsation. Blooms profusely through the Sensation. Blooms profusely through the summer; grand for color masses in hardy beds. Mixture of Gloxinia-shaped flowers; duce many shades. Small Plants, Each 20c: \$2.00 per doz.

Barbatus. Spikes of brilliant coral-red; small flowers. Each 20c; $\$ 2.00$ per doz.

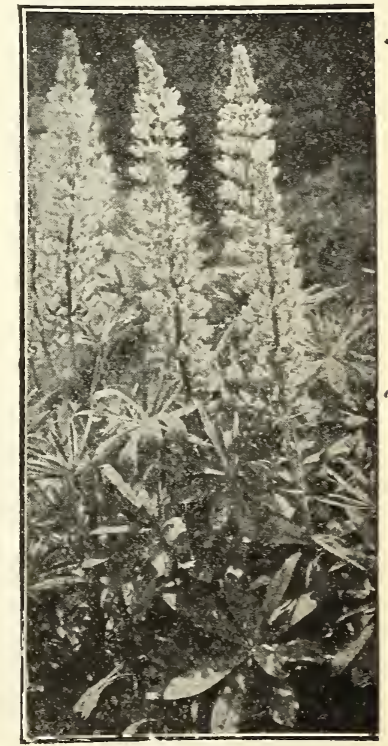

Lupinus 
This class of Hardy Perennials is of special importauce in every flower garden. Succeeds in almost any soil and blooms through a long seasout. ()ur list covers a range of colors which is certain to please.

The best effects to be had with phlox are produced by planting masses of each color, not less than six and even as many as two dozen or more plants of one color together. For example, a border of Phlox nay be planted, beginning with palest pink and slating up to dark cherry, then pure white, and white with a red eye, and more white, then a quantity of red and again white at the end. If in another border the shades of purple are plauterl witls occasional bunches of white, the Plilox will be the pride of the garden. Our ruots are extra large, 2 years old, field-growy.

Price: 20c each; 12 for $\$ 2.00$; except when priced otherwise, als postpaid.

Bridesmaid. IVhite with crimson eye 2 to 3 feet.

Couquelicot. A beautiful pure scarlet with deep scarlet eye. Best of the scarlets and much admired. Each $30 \mathrm{c} ; \$ 3.00$ per doz.

Elizabeth Campbell. Very bright, s:lmon-pink, with dark, crimson eye. Wonderfully attractive. 2 to $2 \frac{1}{2}$ feet. Each 35 c; $\$ 3.50$ per dozen.

Fraulein G. von Lassburg. Largest and purest white. Blossolns are larger than a halfdollar coin. $3 \frac{1}{2}$ to 4 feet.

La Vague. Pure mauve with aniline-red eye, often used for Elizabeth Campbell.

Miss Lingard. White with pale pink eye, considered almost all white, only about 2 feet high and blooms from early July till fall.

Pantheon. Salme 3 to $31 / 3$ feet.

Thebaide. A strong, bright pink, very full blooms of large florets. 2 to $2 \frac{1}{2} \mathrm{feet}$

R. P. Struthers. Cherry-red, suffused with salmon; very graceful shape. $31 / 2$ to 4 feet. Mme. Bezanson. Fiery crimson with velvety-purple eye.

B. Compte. A beautiful purple. 3 feet. Each $35 \mathrm{c}$; 3 for $\$ 1.00 ; \$ 3.50$ per doz.

Iris. Deep violet-blue with large blue center; late. Each $\mathbf{2 5} \mathbf{c}$; $\$ \mathbf{2 . 5 0}$ per doz.

Mirs. Charles Door. A beautiful shade of lavender.

Phlox, Not Named. Contains several popular colors. Each 15c; $\$ 1.50$ per doz.

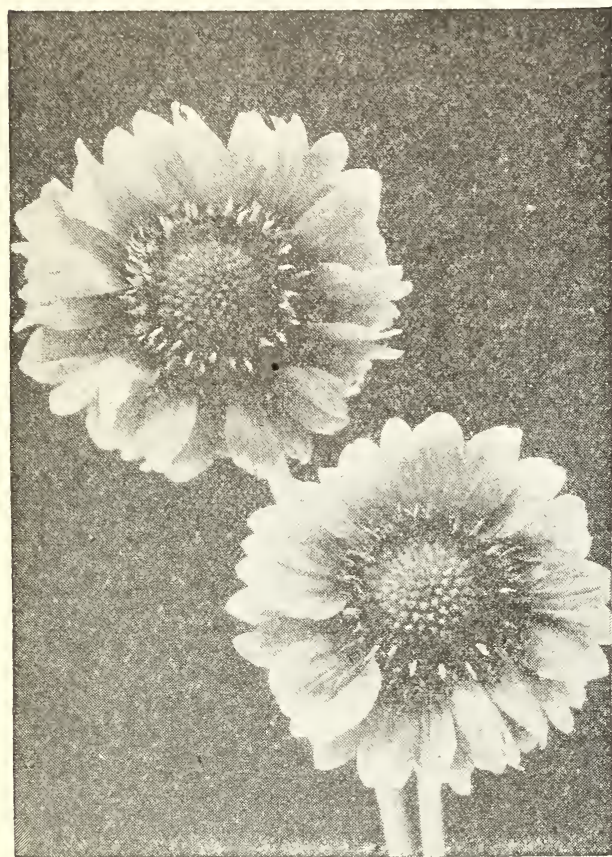

Gaillardia (Blanke: Flower)
PHYSOSTEGIA

\section{(False Dragon-Head)}

Virginica. Forms large plants. 3 to 4 feet high, bearing long spikes of delicate pink flowers tubular in form. Each 20c; $\$ 2.00$ per doz.

Virginica Alba. Pure per doz.

\section{PINKS (Mardy Garden)}

Grass Pinks (June Pinks) A special mixture. Assorted colors. Each $20 \mathrm{c} \$ \mathbf{2 . 0 0}$ per doz.

Crimson Bedder. A beautiful crimson, almost a carnation. Each $35 \mathrm{c} ; 3$ for $\$ 1.00$.

\section{PLANTAIN LILY}

Variegated leaf with Lilac flowers. Each 25c; \$2.50 per doz.

\section{PLATYCODON}

Chinese Balloon Flower

One of the best hardy perennials, producing very showy flowers during the whole season. They form large clumps and are excellent for planting in permanent borders or among shrubbery.

White, also Blue. Each $25 \mathrm{c}$; $\$ 2.50$ per doz.

\section{POPPIES}

Orientale. Immense, large flaming scarlet; very striking. Each 20c; $\$ 2.00$ per doz.

Oriflamme. Large orange-scarlet. Each 25c; $\$ 2.50$ per doz. Princess Victoria. Salmon-nink. Each 25c; $\$ 2.50$ per doz.

\section{PYRETHRUM ROSEUM (Painted Daisy)}

Great value as cut flowers, lasting for days. Perfectly hardy. Easily grown, blooming early summer. Much like Shasta Daisies, excent in color.

Pink, White and Crimson. Separate. Each $20 \mathrm{c} ; \mathbf{\$ 2 . 0 0}$ per doz.

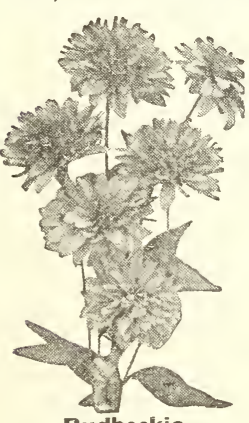

Rudbeckia

(Golden Glow) Mixed Plants: Each $15 \mathrm{c}$; $\$ 1.50$ per doz

\section{RIBBON GRASS}

For background, center of beds, etc. In clumps. Each $15 \mathrm{c} ; \$ 1.50$ per doz.

\section{RUDBECKIA (Coneflower)}

Golden Glow. A popular rich garden yellow flower, double. Each 15c; $\$ 1.50$ per doz.

Purpurea. 4 feet. Border plant having large heads of rosypurple flowers with dark cone-shaped center. Each 20 c; $\$ 2.00$ per doz.

\section{SALVIA}

Azurea Grandiflora (Blue Sage). A Rocky Mountain specie, 2 to 3 feet high, producing during August and September pretty sky-blue flowers in the greatest profusion. Each $\mathbf{2 0}$ c $\$ 2.00$ per doz.

\section{STATICE (Sea Lavender)}

Latifolia. Dense panicles of beautiful lavender-blue flowers. Some call this plant "Lavender Baby Breath:" can be dried for winter bouquets. Each 25c; $\$ 2.50$ per doz.

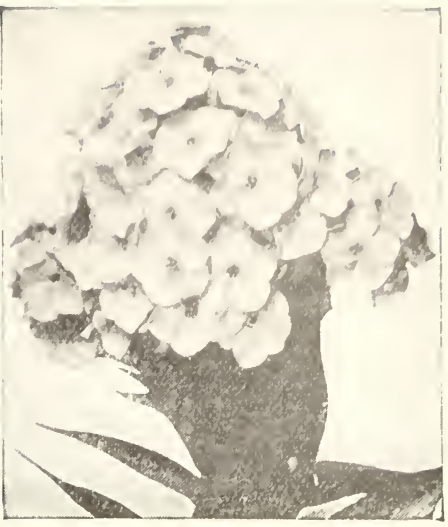

Mardy Perennial Phlox

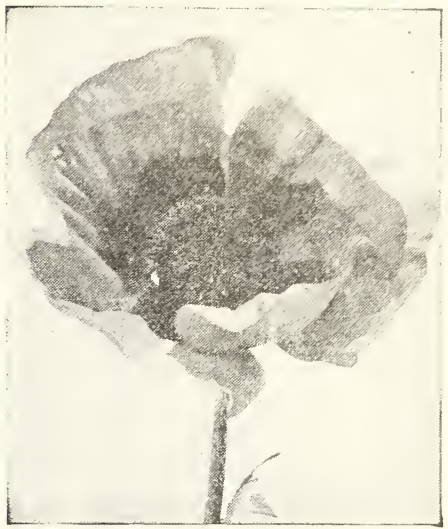

Poppy (Oriertalo

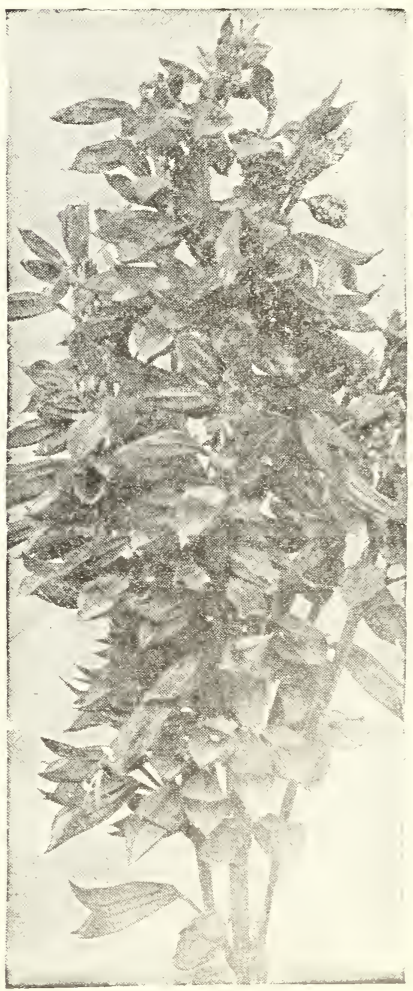

Salvia (Blue Sage) 
Single and Double, Mixed. A grand assortment is in our mixture. Each 20c; $\$ 2.00$ per doz.

Everblooming Hybrid. Brilliant crimson-scarlet. We urge you to buy it. Each 25c; $\$ 2.50$ per doz.

TRITOMA (Red-Hot-Poker)

Pfitzerii Everblooming. Usually hardy. Extremely handsome and showy plants, the flowers borne in compact form on stout 3 -foot stems and having the appearance at a distance of a red hot poker. Each $35 \mathrm{c} ; 3$ for $\$ 1.00$.

VALERIANA (Hardy Garden Heliotrope)

Alba-Rosa. Rose-tinted flowers in trusses. Each 15c; $\$ 1.50$ per doz.

Valeriana Rubra. Very sweet-scented red flowers. Each 20c; $\$ 2.00$ per doz.

\section{VERONICA (Speedwell)}

Spicata. An elegant border plant, 15 to 20 inches tall, with spikes of bright blue flowers in June and July. Very lasting cut flowers for bouquets. Each 20c; $\$ 2.00$ per doz.

\section{VIOLETS}

Garden. Hardy, blue, in clumps. Per clump 20c; $\$ 2.00$ per doz.

Clumps.
Cultural leaflet free upon request, Violet Culture. Indoors and outdoors.

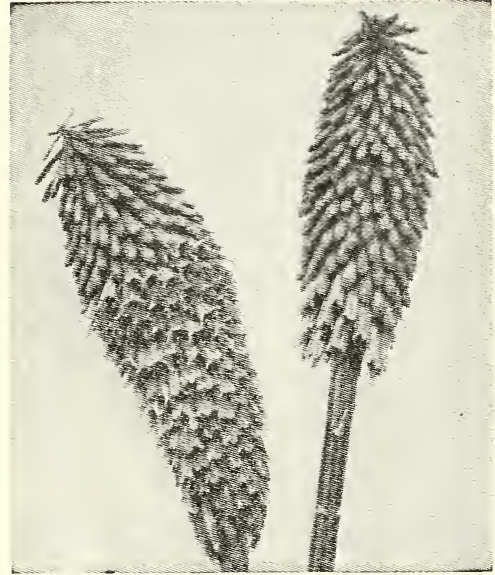

\section{A Perennial Garden, from plants, for immediate effect}

Special Collection 12 Hardy Perennials, one each of the following, Special Collection each one labeled, delivered to you for

\begin{tabular}{|c|c|}
\hline $\begin{array}{l}\text { Delphinium } \\
\text { Shasta Daisies } \\
\text { Pinks } \\
\text { Anchusa (Dropmore) } \\
\text { Coreopsis } \\
\text { Sweet William }\end{array}$ & $\begin{array}{l}\text { Hollyhocks } \\
\text { Canterbury Bells } \\
\text { Gaillardia } \\
\text { Oriental Poppy } \\
\text { Achillea } \\
\text { Gypsophila }\end{array}$ \\
\hline
\end{tabular}

\section{$\$ 2.00$}

SCREEN-GLASS. A patent Hotbed Glass that is excellent covering where forcing plants in early spring. Comes in rolls 36 inches wide, at $42 \mathrm{c}$ per lineal foot. Postage extra. Circular free.

GLASS CLOTH is a prepared cloth that is suitable as a covering over cold frames. etc. 36 inches wide. $\mathbf{4 0 c}$ per lineal yard.

For more details about these protectors, see page 54.

\section{Rock Garden Plants}

25c EACH; \$2.50 PER DOZ. (Unless otherwise noted).

AJUGA, Genevensis (Bugleweed). Creeping habit. Fine for Rock Garden or ground cover. Does well in shady places. Six to eight inches high, abundant foliage and blue blossoms.

Reptans. Similar to above with shiny foliage and violet-blue flowers. Likes sun.

ASTER SPECIES. Very dwarf plants, covered with daisy-like flowers. Any sunny place.

Alpinus. Six to ten inches. Bluish-purple. Subcoeruleus. Many lavender flowers on twelve-inch stems, thru June and July. Both of these small Asters are very good in Rock Gardens.

CERASTIUM, Tomentosum (Snow-in-Summer) 6 inches. Silver foliaged ground cover.

EVENING PRIMROSE, Oenothera Missouriensis. A low growing Rock Garden or border plant with an abundance of immense yellow flowers thru a long blooming season. Good foliage.

GEUM, Mrs. Bradshaw. A very choice low-growing plant that gives a long succession of scarlet flowers. Adapted to either the perennial border or Rock Garden. Especially valuable for the foliage. One foot in height.

HEUCHERA Sanguinea. (Coralbells), Splendid low-growing plants for the front of the border with an abundance of graceful bright crimson blossoms. Fine for cutting. An excellent subject for the Rock Garden. 35c each; $\$ 3.50$ per doz.

IBERIS. Little Gem (Hardy Candytuft). Evergreen prostrate plants that in the Spring are covered with clusters of small white flowers.

\section{Write us about plants which are not listed}




\section{PEONIES (All Postpaid)}

The Peony ranks among the most popular flowers. The blooms come out very early and are seldom attacked by disease. Our roots are extra large. The most popular perennial for our home flower garden. Being perfectly hardy, one planting will do for a lifetime with suitable cultivation. Is strictly. hardy and does well in most anv location; however, suitable cultivion. responds rcadily to good rich, deep soil in an open, sunny position. too deep; the best is for crown to be about 2 inches below the surface. Peonies seldom Ground should be spaded deep and well enriched, as suggested in our free leaflet.

Don't worry about the black ants that of ten gather on the buds, they are seeking the honey which exudes from the bud, and do no harm. If the stalk wilts, remove it to check the fungus from spreading.

Our Special Cultural Leaflet, "Peony Pointers," free with orders if asked for.

Our list contains varieties all distinct, suitable for Colorado culture.

\section{WHITE VARIETIES}

Festiva Maxima. Beautiful large double white with frilled petals and a bright cherry-red spot in center; strong growth with stiff stem. Queen of the whites. Each 50c.

\section{PINK VARIETIES}

Edulis Superba. An attractive bright pink, on a strong stem. Fragrant and freeblooming, often ready for Decoration Day. Each $\mathbf{5 0 c}$.

Golden Harvest. Soft pink outer petals with a creamy gold center, medium size. A much admired variety. Each 50 c.

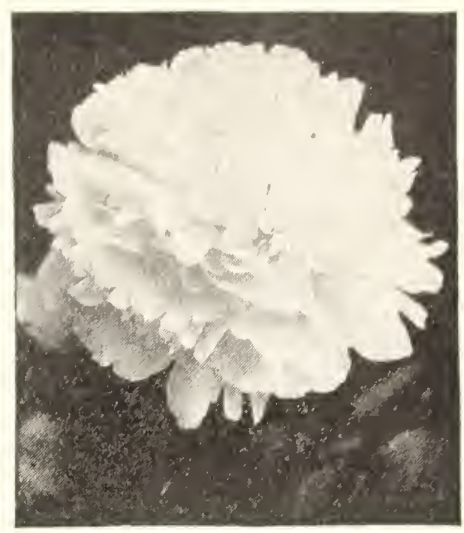

Festiva Maxima Peony

La Tullpe. Large, late delicate rose, fading to creamy-white. This is an extra fine Peony. Each 50c.

Baroness Schroeder. Mid-season to late. Color flesh-pink, changing to white creamy center. Strong grower, free bloomer; a beauty. Each $\$ 1.00$.

Mons. Jules Elie. Very large, globular, double pink blooms on erect stems. Beautiful silvery-pink shading deeper towards the center. A vigorous grower, free-bloomer and very fragrant. One of the best pink varieties. Each \$1.00.

\section{RED VARIETIES}

Delachel. Violet-crimson, good medium size bloom for cut flower, stiff stem. Each $60 \mathrm{c}$.

Francois Ortegat. Large deep crimson with golden center, not a full double but very free bloomer. Each 60c.

Felix Crousse. One of the grandest brilliant ruby-red. Rich, solid color, strong grower, medium late. The best of its class. Each 60c. Karl Rosenfleid. Very large. Early, beautiful blood-red, of globular shape. Tall. Free bloomer. Each \$1.00.

Rubra Officinalis. The earliest of all peonies and very brilliant red, though sort of semi-double. Very sure to bloom by Memorial Day. Each $\$ 1.00$.

\section{UNNAMED PEONIES, BUT SELECTED TO COLOR}

Whites. Many good varieties. Each 35c.

Pinks. Include several shades. Each 35c.

Reds. Light and dark mixed. Each 40c.

One each, Red, White and Pink, $\$ 1.00$.

Peony Shows In addition to the Annual Peony Show held In Denver in June of each year, prepare for the big Natlona Peony Show to be held in Denver this year. Plan your stock for it. Denver City Parks are to have extra plantings for this special occasion.

\section{Iris, Hardy or Germanica $\underset{\text { Postpaid }}{\text { All }})$}

A flower that is at home in any garden, shady or sunshine. Is easily cared for and gives big returns in beautiful flowers, some of which are quite equal to Orchids. If soil is soggy or apt to be watered heavily, then plant on slightly raised hills or ridges.

They are strictly hardy and sure to please. Try some of the new varieties. Our list gives a wide range of colors. All are postpaid. Cultural leaflet on request, Iris. Both bulbous and roots.

The following varieties are each $35 \mathrm{c}$.

Ambassadeur. Standards a fascinating smoky velvet-purple color, falls velvety purplemaroon, beards yellow. A magnificent and regal flower of real substance. One of the very best of all Irises.

Black Prince. Standards are intense purple-lilac, falls rich velvety-black. A remarkable novel combination of colors. Very scarce and rare.

Mother of Pearl. Light lavender-blue, glossy, falls are slightly deeper than standards and the whole with a faint creamy undertone. Flowers are perfect and exceptionally beautiful. Tall grower, profuse bloomer, a real gem among Iris.

The following varieties are each $20 \mathrm{c}$; per dozen $\$ 2.00$.

Eldorado. Standards yellow-bronze and heliotrope; falls a bright violet-purple. Very beautiful and effective.

Lent A. Williamson. Standards erect lavender-violet, blended with yellow toward base; falls rich royal purple, beard yellow. Tall and large. Considered by many the finest variety ever raised in America.

Monsignor. Rich satiny-violet and purple-crimson.

Sherwin Wright. Perfect, clear, deep golden-yellow.

White Knight. Absolutely cool snow-white. Sweet-scented.

The following varieties are each 15c; dozen for \$1.35.

Aurea. A beautiful clear chrome-yellow.

Her Majesty. Rose-pink standards, falls veined darker.

Isoline. This French variety has become very popular on account of its immense blooms, which give a rose color effect. The standards are a lovely rose-pink while the falls are an old rose with a golden throat.

La Nelge. Pure glistening waxy-white. Truly exquisite.

Oriaflamme. Standards lavender-blue; falls rich violet-purple. Immense size and very sweet-scented. Edges waved and crimped. You should include this.

Lohengrin. Large silver-mauve. Very large flower.

Pallida Dalmatlca. Standards lavender, falls of deeper lavender. Flowers extra large and very fine.

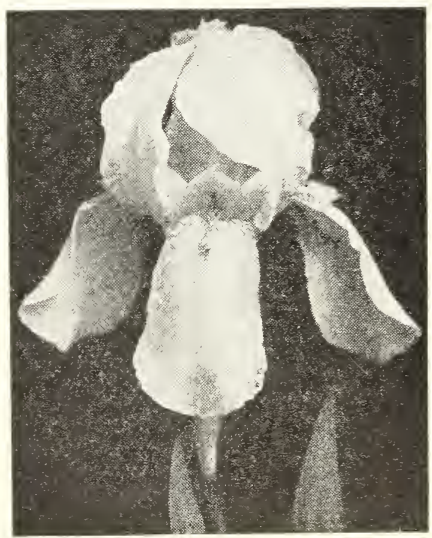

White Knight Iris
The following varieties are each 10c; dozen for $\$ 1.00$.

Flavescens. Cream color, popular in every garden.

Florentina Alba. The popular pure white variety.

Florentina Purple. Similar to Alba, except in color.

Iris KIng. Standards coppery-yellow; falls crimson, bordered yellow, large striking flower.

Sans Soucl. Standards are golden color. Falls are mahogany-red. Late bloomer. Very effective.

Queen of May. Lavender pink; the nearest pink in Iris.

\section{MIXED IRIS AT 75C PER DOZEN}

Good ordinary varieties of many colors and combinations, grown mixed. Splendid for mass plantings. 


\section{HARDY GARDEN LILIES $\stackrel{\substack{\text { ALL } \\ \text { Postrald }}}{\text { HAR }}$}

Stately Lilies are of the easiest culture, and the varieties listed below are all perfectly hardy. After once being planted, they will increase in beauty and size with each succeeding year. they will increase in beauty and size with each succeeding year. rich, and the plants should be given plenty of water during periods of drought. In order to grow Lilies to large size, the bulbs should be planted deeply; approximately covered 3 times the thickness of the bulb. Our stock of Japanese Lilies, imported direct, is ready in March. Order liberally while they are available. Cultural leaflet free upon request, Lily Culture. In greenhouse and hardy varieties outdoors.

Album. Pure white, of medium-sized flower. Each 40c; per doz. $\$ 4.20$.

Auratum (Golden Banded Lily of Japan). Goldenbanded, white, with red spots and stripes; very beautiiul. Usually received from Japan in November and December. Cover 9 to 12 inches; height 3
Blooms July, August. Each 40 c; per doz. $\$ 4.20$.

Bulbiferum (Bulb-bearing Lily). The prevailing shade is yellow-orange; the tips of each petal being slightly flushed flame-red. Cover 3 times thickness of bulb. Blooms June, July. Each 40c; per doz. \$4.20.

Croceum (Orange Lily). Thrives in ordinary garden soil and is most suitable for town gardens. A robust grower with beautiful orange-colored upright blooms. Cover 3 times thickdoz. $\$ 4.80$.

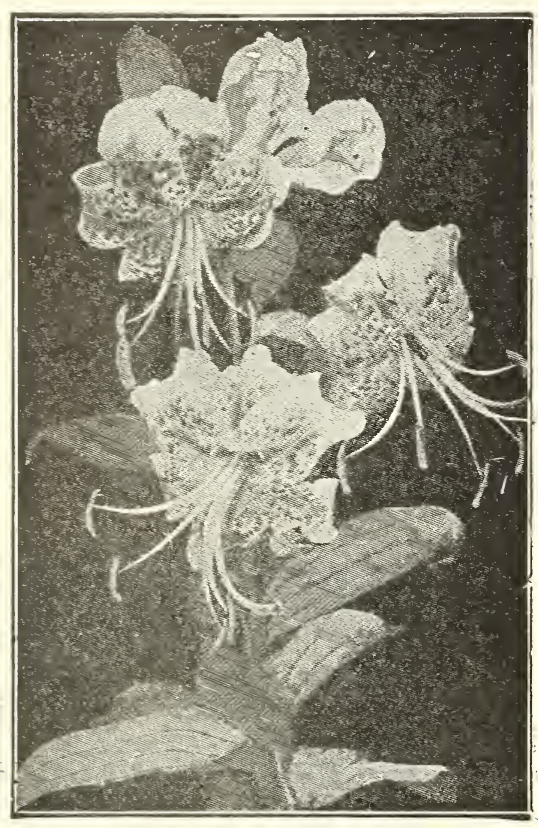

Tigrinum Splendens

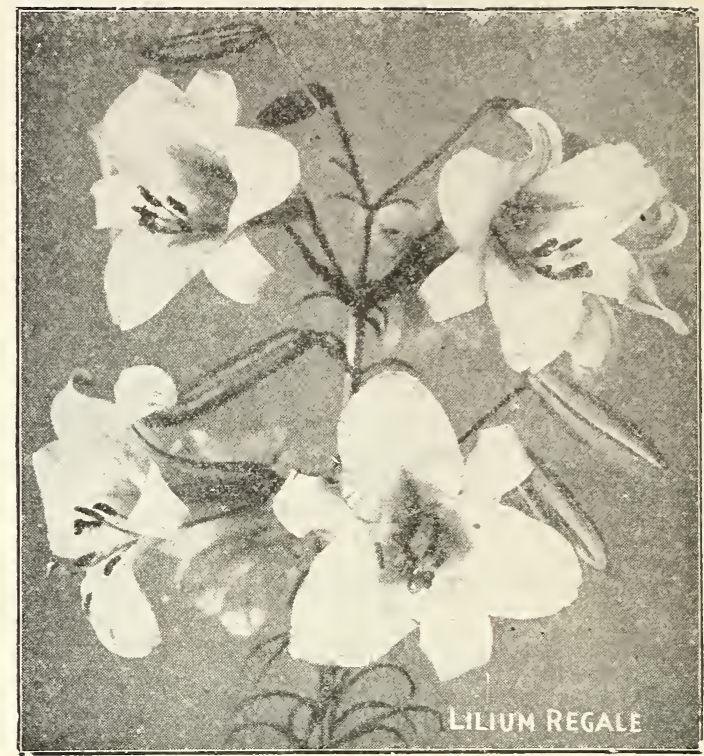

Elegans.

Best of its class, being bright red.

Amer-

grown.

Each 35c;

per doz.

$\$ 3.60$.

Hansoni. Blooms in early July. A deep orange-yellow spotted brown reflexed. doz. 55,00

Henryi (Orange Speciosum Lily). Of vigorous growth and will thrive in any soil. If planted in partial shade the rich orange coloring of the flowers will be highly If planted in partial shade the rich orange coloring of the flowers will be highly plants will go higher. Blooms July, August. Very prolific bloomer. Each 60c; per doz. $\$ 5.50$.

Krameri. The funnel-shaped blossoms are 4 to 6 inches long, of a beautiful clear pink color, shaded blush. Very unique. Each $40 \mathrm{c}$; per doz. $\$ 4.20$.

Rubrum (Roseum.) Deep rose to red with white streaks; very beautiful and much admired. Each 40 c; per doz. \$4.20.

Regale (Illustrated on third cover in full natural colors). A

magnificent Lily; the pure white flowers. heavy with fragrance height 3 to 5 feet; blooms July, August. Large bulbs, each $\mathbf{4 5 c}$; per doz. $\$ 4.80$; regular size, each $35 \mathrm{c}$; per doz. $\$ 3.60$.

Tenuifolium (Coral Lily). Narrow-leaved, slender-growing, attractive little Lily from Siberia, growing average 18 inches, never more than 24 inches, with numerous deep scarlet, recurved flowers on Each 30 c; per doz. $\$ 3,00$

Tigrinum (Tiger Lily). The old popular that should be in every garden. Orangered, black spots. Ready in September. Cover 9 inches. Height 4 to 5 feet. Blooms August, September.

T. Splendens (Single). Each $20 \mathrm{c}$; per doz. $\$ 2.00$.

T. flore pleno (Double). Each 25c; per doz. \$2.50.

Umbellatum Erectum (Candlestick Lily). 1 he bulbs of this species are usually large, early-flowering and robust. Large red flowers. Cover 3 times thickness of bulb. Height 2 to $21 / 4$ feet. Blooms June, July. Each $35 \mathrm{c}$; per doz. $\$ 3.60$.

Lily-of-the-Valley Pips. See under Summer-Flowering Bulbs, page 17. BOOK, "Consider the Lilies," by Marshall, 92 pp., handsomely bound, replete with colored illustrations. All about Hardy Lilies. Each $\$ 1.00$.

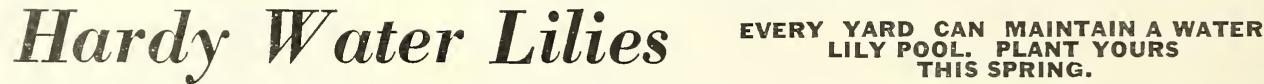

Hardy Lilies are perfectly hardy anywhere in the United States, growing wild as far north as Canada. They commence flowering early in the spring and remain in flower until late summer. The flowers mostly float on the water and are in shades of Pink, Yellow and White.

\section{AN INEXPENSIVE WATER GARDEN}

You can enjoy a water garden without the permanent investment of a concrete pool. Discarded water tanks, sawed off to the proper depth; old vats, tubs, bathtubs, barrels, trays, and other containers may be had for very nearly the hauling away. Visit the yards of a wrecking company. Patch leaks with hot asphaltum. which can be secured from any roofing company, applying when container is thoroughly dry.

Sink about 2 feet in the ground, in a sunny spot, filling one-third full of soil; plant, 2llowing one Lily for an ordinary tub, other containers in proportion. Cover soil, which should be good garden loam, with sand or small pebbles to help keep the water clean. Pools 2 feet deep are standard, which allows for at least a foot or more of water over the plants. It is well to remember that the roots spread out laterally, not growing down very deep. Keep the water level fairly constant and the pool clean. Do not drain very often, but allow hose to flow in and overflow for an hour or so if pool becomes murky.

In May and June we can supply direct from a Colorado grower, assuring you fine clumps of white, pink and yellow-flowered varieties. The fact that these are Colorado-grown will more than offset any doubt as to your success.

Thite (Nvmphaea Odorata). Each \$1.00. Shell Pink (Marliacea Pink). Each 16

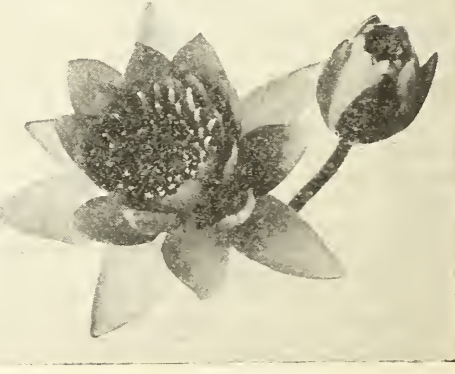

Hardy Water Lily 


\section{Summer Flowering Plants and Bulbs}

ALL UNDER THIS HEADING ARE PREPAID UNLESS STATED OTHERWISE SUMMER BEDDING PLANTS

We supply from our store nearly all the popular and easily grown plants for bedding. ()n account of cost of ()rofinctin pace, fuel and labor-we do not give prices here except for our specialties. Ask for new list to be ready alout A pril 1 , that will include Antırrhinum, Coleus, Daisies, Dracenas, Geraniums, Heliotrope, Lobelia, Marguerites, Petunias, Sálvi

Asters These plants are grown expressly for our trade from Bodger's strain of Giant-Branching Comet Aster secels that is highly Asters esteemed by many gardeners. We supply plants separately in colors.

White, Pink, Lavender, Crimson, Purple, Light Blue. Ready in May and June. Per dozen 50c; per 100 $\$ 3.50$; postage extra.

Average Mixed Colors. Grown mixed. Per dozen 40c; per 100 \$2.50. If by mail, add 10c per dozen.

Pansy Plants The seed is selected from choice plants and saved expressly for our use, which were started last fall and now are in that are prize-winners. Best ever-none better. Each plant is wrapped so that bloom shows; will keep nicely for days. Per dozen 50 ; per $100 \$ 3.50$. If by mail, add $15 \mathrm{c}$ per dozen. However, ship by express when possible. Illustrated on page

\section{SUMMER FLOWERING BULBS--.Postmaid}

\section{Amaryllis Bulbs are ready in winter to May 1. Do well in pots or open} Equestre. Beautiful orange-scarlet. Each 25c; doz. \$2.50.

Johnsonii. A beautiful large red. Each 45c.

Giant American Hybrids. The new type of large-flowered, in many mixed shades. Each $60 \mathrm{c}$.

Anemones Called Windflowers. Semi-hardy. That should be planted in flowers. Our gtock is a special mixture from California. Each 10c; doz \$1.00; 100 for $\$ 6.00$; postpaid.

Caladiums (Elephant Ears). Very effective as foliage plants in center For best results of beds. Require plenty of moisture and heat. No blooms. Medium size. 7-9-inch circumference. Each 15c; doz. $\$ \mathbf{1 . 5 0}$

Callas Yellow. Spotted foliage; a beautiful yellow; does well in pots; needs Average bulbs $25 \mathrm{c}: 3$ for $70 \mathrm{c}$

White Calla Bulbs are available only in the fall. See Fall Bulb Catalog.

Cinnamon Vine Sweet-scented, with glossy foliage. Usually perennial.

Lily of the Valley Pips For outdoor use. Cover one inch only. too thick. Everyone knows these fragrant flowers. Imported stock. Per
doz. $\mathbf{7 5 c ;} \mathbf{1 0 0}$ for $\$ 5.00$.

Madeira Vine A tender climber much admired for the waxy-green leaves must be taken up each fall. Average size tubers, each $10 \mathrm{c} ; 3$ for $25 \mathrm{c} ; 12$ for $90 \mathrm{c}$. Small, but good tubers, 3 for $15 \mathrm{c} ; 12$ for $50 \mathrm{c}$.

Montbretias Mixed. Fasily grown, gayly colored flowers in shades of Montbretias yellow, salmon, orange and scarlet. Hardy if protected with covering of leaves. Each $10 \mathrm{c} ;$ per doz. $\$ 1.00 ; 100$ for $\$ 7.00$.

Oxalis (Summer Flowering).

borders. For masses in beds and White, Pink. Separate, large bulbs. Per doz. 30c; 100 for $\$ 1.75$.

Tigridia (Tiger or Shell bous plants suitable for the mixed border, which can be handled same as Gladiolus, growing average 12 inches high, producing their fine flowers in late summer. Bulbs harvested like Gladiolus. Gorgeous flowers, scarlet, creamy-yellow and rose-carmine, with unique center blotch; the tiger-like colors are handsome. Each 25c: colors are han
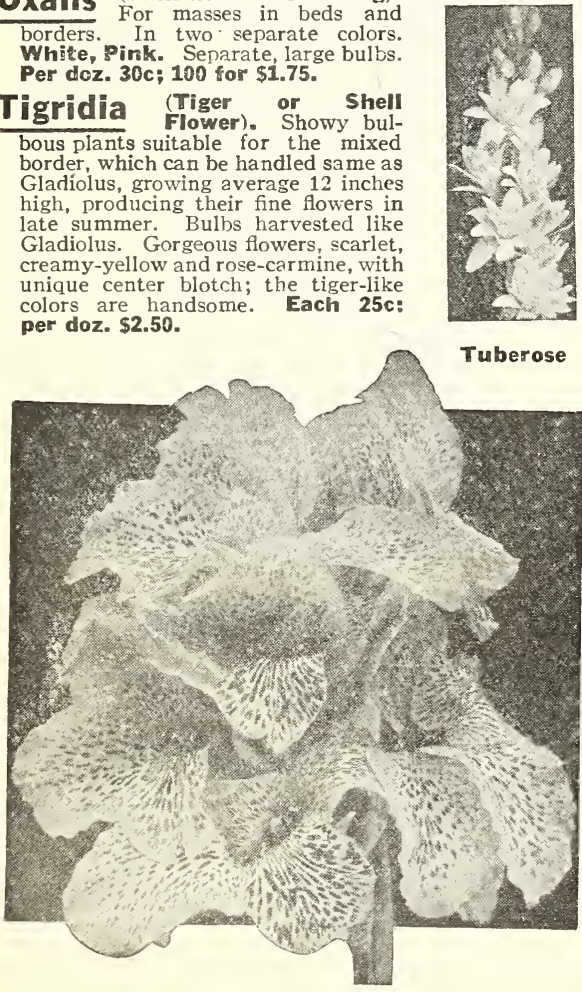

Yellow Humbert

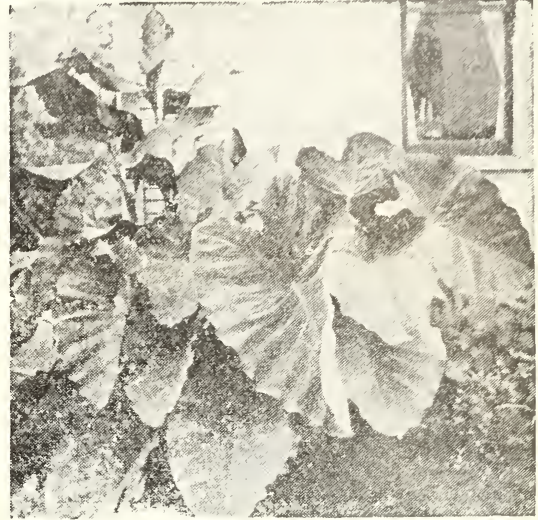

Caladium-Elephant Ears

SEEDS, BULBS, ROOTS, TUBERS Entitled to Second Claas Express Rates. Tuberose Bulbs $\begin{gathered}\text { Much liked for the very exquisite fragrance and } \\ \text { beautiful flower. You get more blooms when }\end{gathered}$
you start them indoors in March and April, then set out in open ground in Tuberose Bulbs
you start them indoors in March and April, then set out in open ground in
beautiful flower. You get more blooms when May.

Dwarf Pearl. Come usially double, very abundant bloomers, Each $10 \mathrm{c}$; doz. $\$ 1.00 ; 25$ for $\$ 1.75$.

We have discontinued the Mexican. They are not desirable, compared with the double.

\section{CANNAS Very Choice}

Our stock includes the very choice and desirable varieties grown by a specialist. Procure your bulbs early, start them indoors, then you are sure of success. Bulbs ready in March.

\section{DORMANT BULBS}

The following six varieties include the very cream of all Cannas. You get strictly distinct and desirable varieties. Why plant the old unpopular varieties?

PRICE, unless otherwise stated: Each 15 c; 2 for 25 c; 12 for $\$ 1.25$ King Humbert, True. Fiery-red with bronze foliage. Most popular Canna grown. 4 feet.

Pennsylvania. Scarlet with glossy green foliage. 4 to 5 feet.

Yellow Humbert. Lemon-yellow with red stripe; green foliage, with occasional bronze leaf. 4 feet.

Richard Wallace. Canary-yellow, light green foliage. An excellent bedder. 4 feet.

Orange Bedder. Blood-orange with deep green foliage; a very free bloomer. 4 feet.

Hungaria. Rose-pink, large flowers. Best of the pinks. 4 feet. Each $15 \mathrm{c}$; dozen $\$ 1.50$.

Mixed Cannas. A good assortment, though not named, 6 for $50 \mathrm{c} ; 12$ for $90 \mathrm{c}$.

\section{CANNA COLLECTION}

\section{A Wonderful Bed or Border}

2 King Humbert 2 Yellow Humbert

8 bulbs of four named $75^{c}$ varieties, all for 
The Dahlia is one of the very satisfactory flowers for the home flower garden. The bulbs are inexpensive, almost sure to grow and produce most attractive flowers, lasting up to frost time. Many of the newer varieties are wonderful in size and colorings, while everyone in our list is of merit. We urge customers to add a few of the newer varieties.

There are several classes of Dahlias, such as Show Dahilas, Peony-Flowered, Decorative, Cactus, Single ard Pompon. We have included in our assortment some of each. You can get a very complete Dahlia garden planting from us.

Cultural Leaflet on Dahlias free for the asking.

\section{Dahlias of Special Merit}

In this list you get the very cream of choice varieties. The tubers are all properly labeled. Please do not judge the merit of the flower by the size of the bulb, since some of the very best are extremely small bulbs.

\section{SUPERB EXHIBITION DAHLIAS}

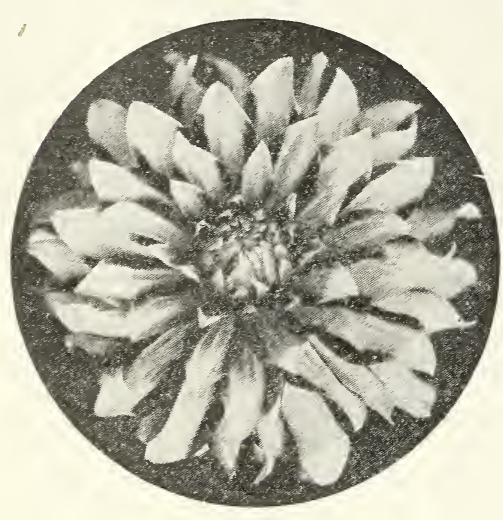

Chas. Stratton

CHAS. STRATTON (Decorative). A hlue ribbon winner in the largest bloom class. Flowers massive, keeping well when cut. Blooms early and profusely on strong stems. Color, pale gold shaded and tipped rose-red. \$2.50 each.

CHEMAR'S PURITY (Decorative). The best pure white. Flowers 8 to 10 inches,

EAGLE ROCK BEAUTY (Hybrid Cactus). A large, free-flowering, soft pink, tinting to ivory at tips of petals. \$2.50 each.

EDNA FERBER (Hybrid Cactus). Glistening coral, shading to old rose. A splendid Dahlia with good stems and foliage. \$2.50 each.

ELITE GLORY (Decorative). One of the best giant reds. A truly spectacular Dahlia. Good stems and foliage. \$2.00 each.

ELIZA CLARK BULL (Decorative). One of the best white, of splendid form on long, strong stems. \$2.00 each.

FORT MONMOUTH (Hybrid Cactus). A glorious Dahlia of a rich handsome maroon color, shaded bluish-violet at the tips of the petals. Long stems, very large, and a splendid keeper. \$2.50 each.

JANE COWL (Decorative). A large flower of a warm buff and old gold, blending to a bright salmon at the center. The giant flowers are held aloft on rigid stems. A superb Dahlia in every

way. $\$ 3.00$ each.

\section{JERSEY BEACON (Decora-}

tive). A decided novelty of Chinese-scarlet with a paler reverse, giving a twotoned effect. An exhibition flower of vigorous growth, excellent stem. \$1.50 each. MARGARET WOODROW WILSON (Decorative). Large flowers of opalescent Dink, reverse phlox-pink. Fine stems and foliage. \$1.50 each.

MARIAN BROOMALL (Hybrid Cactus). A truly beautiful Dahlia. Color, clear light lilac, shading lighter at tips with white center. Bush growth and

stems very good. A Dahlia you will like. $\mathbf{\$ 1 . 5 0} \mathbf{e a c h}$.
MAY TROWER (Hybrid Cactus). This is a splendid variety that is always admired. It is an old gold tinted with mauve. The flowers are large on splendid

ROSE FALLON (Decorative). An immense flower of fine, perfect form. Stems
stems. 2.50 each. long and erect. Plant robust and vigorous. Color, dark amber or brownish old gold. A variety we can highly recommend. \$1.50 each.

SANHICAN'S PEACH (Decorative). Charming, fluffy. In color it is a reddishsalmon with buttercup shadings, reminding one of a ripe California peach. Its attractiveness is further enhanced by the oddly twisted petals. Rich dark green foliage, upright stems and good habit of growth. \$2.50 each.

SILVERADO (Hybrid Cactus). White, shading to delicate silvery-lavender. $\$ 2.00$ each.

THE LEMONADE (Decorative). Although we have a number of yellows, this

Dahlia is becoming very popular because of its beauty, size, erect stems, good
habit of growth and wonderful keeping qualities. Color, clear yellow. $\mathbf{\$ 2 . 5 0}$ each.

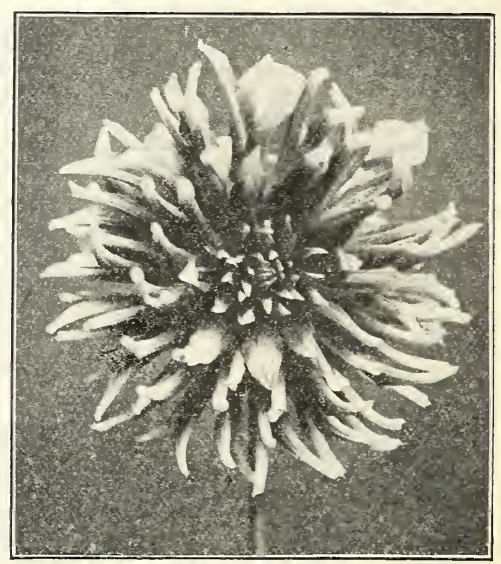

Edina Ferber

\section{Extra Fancy Dahlias at $\$ 1.00$ Each 6 FOR $\$ 5.00 ; 12$ FOR $\$ 9.50$; YOUR SELECTION}

Bonnie Brae. Decorative. Cream, shaded blush-pink; the flowers are of true decorative form and immense in size. One of the best. suffused primrose and gold; reflexed carmine-pink. Daddy Butler. Hybrid Cactus. A large, fine variety, on good stems. Color rose-carmine. A very attractive flower.

leanor Martin. Decorative. This is a California variety of exceptional merit. The coloring is unique; different from all others - a beautiful mulberry with golden suffusion. The form is of best exhibition type. Very large flowers can be grown to ten inches in diameter on stiff, long stems.

aith Garibaldi. Decorative. The color is a charming silverypink' Blossoms are ideal for cutting.

deal. Decorative. Color lavender-pink to phlox-pink; Kenneth Gilbert. Decorative. Color light pink, shading to cream-pink, on rigid stem. Fine large flower.
Kittie Dunlap. Decorative. A large flower carried on excellent stems; an early and constant bloomer. Color carmine-rose,

Lewis, Jr. H. C. Large, gorgeous, velvet-red, shading deeper to center. On exceptionally long, stout stems. Keeps easily five days to a week after being cut. One of the very best.

Maid Marian. Hybrid Cactus. Flowers large and produce freely on good stems. Petals curve and twist, giving the flower a shaggy appearance. This variety is highly recommended. Color rose-pink. A very handsome variety.

Mariposa. H. C. Beautiful shade of true pink; center intensified and suffused with a faint violet, which adds to the beauty of this variety.

Marmion. H. C. A giant Dahlia of lovely coloring. Pure goldenyellow with a bronze center, and reverse of petals reveals a bronze suffusion. The blooms are held on good stems well above the foliage of the sturdy, strong-growing plant. Good exhibition variety. 


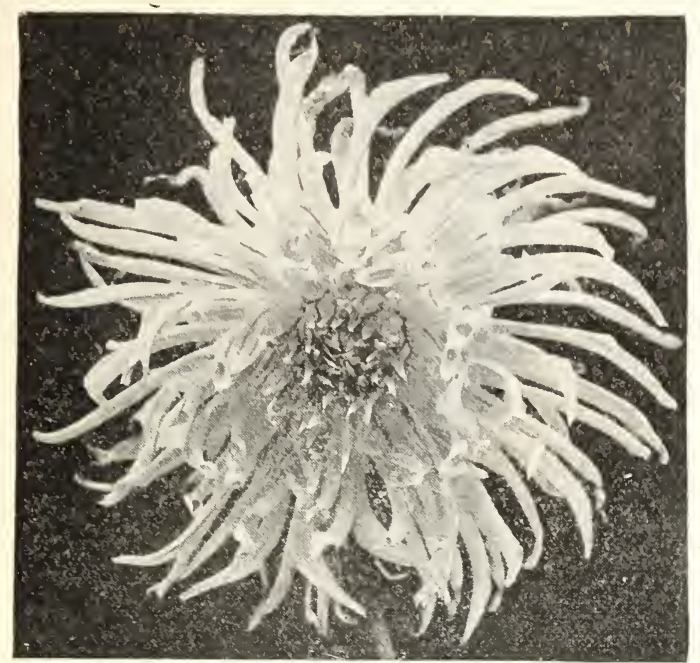

Maid Marian (Listed on page 18)

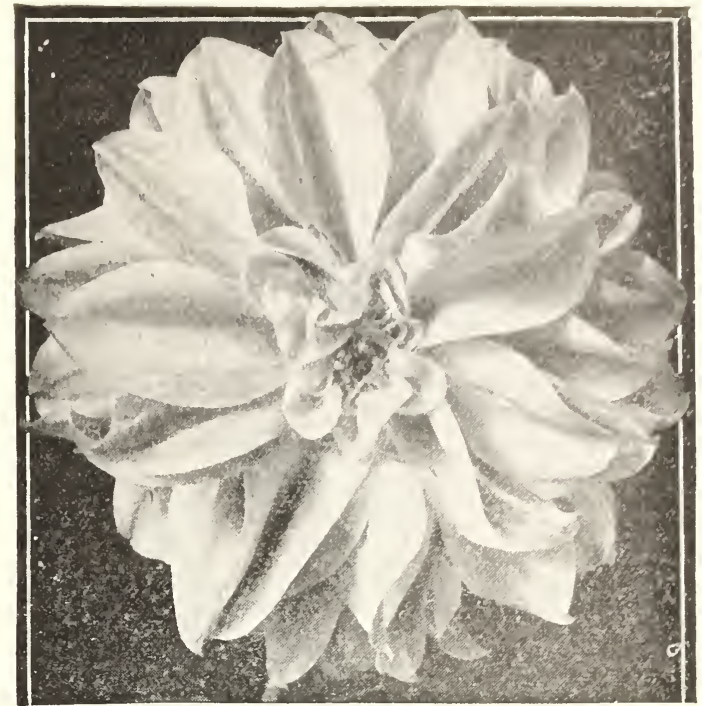

Pattisumma

\section{Extra Fancy Dahlias at \$1.00-Continued-All Postpaid}

Miss Colorado. Peony. Pastel-pink, shading to silver at outer edge of the petals.

Nobilis. Decorative. Combination of white and red. It differs from Earl Williams in that the white predominates.

Pahaska. Decorative. Color apricot-fawn. Immense size; one of the best.

Pattisumma. Decorative. Large flowers with broad petals on long stem. Color rich purple.

Pride of Fort Morgan. Decorative. A wonderful intense red. Flower measures 10 inches.

Radio. Decorative. Without a doubt one of the greatest Dahlias ever originated. Can be grown 11 to 12 inches in diameter Color blood-red, edged and tipped with yellow.

Robert Scott. Decorative. This fine new Dahlia is of a bright apricot-yellow with shades of rose. Flowers are large and deep, of good form, on excellent stems. The bush is of stocky growtl.

Robert Treat. Decorative. A bri'liant American Beauty-rose shade, stiff, upright stems; winner of many medals.
Roman Eagle. Decorative. Flaming-copper colored flowers on

Salbach White. Decorative, Large flovers, pure white, nice stems. Siskiyou. H. C. Here we have the Dahlia that has won in the largest bloom class repeatedly, but on diameter, not considering depth. Flowers held erect on long, strong stems. Color, pink tinted mauve. Petals rather blunt and flat.

Trentonian. Decorative. A giant decorative of a shade that appeals and captivates at one glance; the color is that of an Indian's skin, a Wonderful blending of old gold, amber anc rarden -

Uncle Sam. This is one of those monster Peony-flowered Dahlias. Color orange-buff, shading bitter-sweet pink at tips. Stems william G. Plant of sturdy, well-branched habit. Stems ample, long and wiry, holding the immense flowers erect. Flowers of excellent keeping qualities. Color light or scarlet-red. A wonderful flower.

\section{Exhibition Dahlias at 75c Each}

SIX BULBS (ALIKE OR ASSORTED) YOUR SELECTION FOR \$4.00. Atlantic Ocean. Hybrid Cactus. A fine large flower borne on strong stems. Blooms well above the foliage. Color bright lemon. Fine in every way.

Ballet Girl. Cactus. A beautiful large flower of perfect form. Color soft orangescarlet marked with pure white. One of the best of the cactus varieties.

Jersey's Beauty. Decorative. A fine true pink decorative Dallia of perfect form on long stiff stems that hold the flowers high above a strong, vigorous plant. 5 feet.

Jessie Seail. Peony-Flowered. A unique color in the Dahlia family, clear old rose, a pleasing and popular shade; flower very large and of ideal Peony form; stems often 2 feet in length; yet strong and erect; no better general-purpose Dahlia grown.

Judge Marean. Decorative. Glowing salmon-pink, red iridescent orange, yellow and pure gold. Profuse bloomer.

Kiwanian. Peony. American Beauty-red, shading to purple-red. Stems 18 to 24 inches long. Flowers 9 to 10 inches.

Ninfea. H. C. A lavender-pink shading to creamy-white, with broad petals incurved, greatly tesembling a water lily, from which it derives its name. A rery profuse bloomer.

Ophir. A superb decorative, borne on long fine stems, holding the flower to view: Flowers medium size with full center. Color rich old gold with amber shading, reminding one of the popular Lucy Davis. Fine exhibition flower.

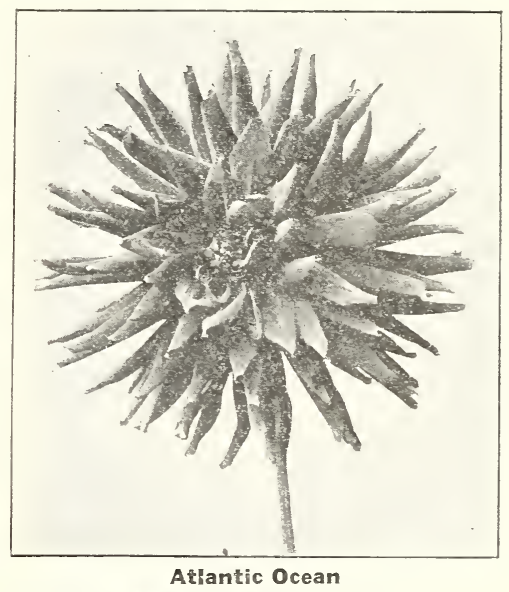

\section{EXTRA SELECT DAHLIAS AT 50c EACH (ALL ARE LABELED)} 6 YOUR SELECTION FOR $\$ 2.75 ; 12$ FOR $\$ 5.00$. (CAN BE ALL ALIKE OR ASSORTED.)

Alpine Wonder Hybrid Cactus. Flowers snowy white, large and full, produced in groups of three, each on fine long stem. An

early and constant bloomer.
Amun Ra. Decorative. Color copper-orange to golden-bronze. Andy Gump. Decorative. Color bright red. Stem 18 to 36

Augusta Johnson. Decorative. A large fine flower on excellent Augusta Johnson. Decorative. A large fine fower on excelle

Avalon. Decorative. One of the largest of Dahlias, with fine stem, and a good keeper. Clear, rich yellow. Highly recommended.

Bashful Giant. Decorative. One of the largest Dahlias introduced. The immense blooms are excellent for exhibition; the color is apricot with golden shadings.

Bob. Pleuse. H. C. Dark maroon, heavily

Dend

A Decorative. A finwer of medium

A pretty shading

Charm. Decorative.

burnt

chicota. Peony-flowered An ideal

and exceptionally long stems often 18 inches

form and clear in its ri

chipeta. H. C. Mammoth flower borne on long stems which hold

the flower erect. Rich purple in color.
Desert Gold. Decorative. Pure golden-yeliow. Large, superb

flowers. 
Extra Select Dahlias at 50 cents each-Contd. Doris Wilmore. Peony-flowered. Rich apricot-bronze. Good stem, holding Elinor Vanderveer. Decorative. 'Similar in type to I. De ver Warner. This new variety is even larger, and a beautiful shade of true light pink. Clean, vigorous plants of erect habit, holding flowers high on perfect stems. A sensation wherever grown.

mina slocum. Decorative. Pure white flower on extra long stems. Flowers the showiest of the white decorative varieties.

Strong plant, height 6-7 ft. Flowers large, delicate pink,

E. P. Miller. A red Decorative hard to describe, rather a glossy light red. Its large, broad flat petals curving slightly outwards. These large flowers averaging 10 inches across, are held well above the foliage on long wiry stems. A fine Dahlia. Ethel T. Smith. It is certainly a monster in size and growth of plant. Color
creamy-white with a slight lemon tint. In type it would be classed a hybrid

Glory of New Haven. Decorative. A fine large flower of perfect form, borne on long stems. Color lavender or orchid-pink. A fine Dahlia.

Golden West. Cactus. Superb flower of exceptional size, of ten 7 inches across stems long and rigid, holding the flower to full view; color golden-yellow, shaded to pure yellow in center; has no superior.

Happy Dream. Peony flowered. Plant ideal in growth. Stems long and wiry, holding the flower to full view. Flowers large and of good substance. Color bright pink, shaded lavender-pink. Fine in all points, 5 feet.

J. D. Long. Peony-flowered. A blending of autumn tints of salmon, pink, amber and bronze. Long stems and large flowers.

Justice Bailey. Cactus. Color rich glowing pink, shading a ittle lighter toward center.

Halveila. Decorative. Old rose-pink with a golden sheen is one of the finest for exhibiting and cutting. These irresistible blossoms of great size, substance and unusual keeping qualities are held erect on long, stiff stems and hold their centers throughout the seas

Kalif. Cactus. Truly majestic flower, frequently measuring over 9 inches in diameter, of perfect Cactus form; in color a pure scarlet; the habit of the plant is all that can be desired; the gigantic flowers, which are produced very freely, are held erect on strong, stiff stems, making it a most effective and usefu variety for cutting as well as for garden decoration.

Le Grosse Bete. Decorative. A glorious enormous flower held straight upon strong stems and of a cerise self-color.

Laura Barnes. Beyond question one of the grandest Peony Dahlias ever introduced. Only words of praise have come from those who grew the variety last season. The immense orange-red flowers are pleasing to all. It is today one of the most popular Dablias of recent introduction.

Laurence Ruppel. A new peony-flowered variety of surprising beauty. A large fluffy flower, produced on long stems. Petals broad and slightly incurved toward the center. Color rich copper-red, shading apricot. A profuse and constant bloomer. Strong tubers.

Laurine. An immense Cactus Dahlia. It has fine stems and good habit throughout. Flowers are very large and perfect in their formation. Deep rich pink; a fine variety.

Liberky Eond. A fine large flower, decorative in form. Extra strong, erect stems and flowers of great substance. By disbudding, this variety will produce flowers of immense size. Color clear buff or rich anricot. A noble flower.

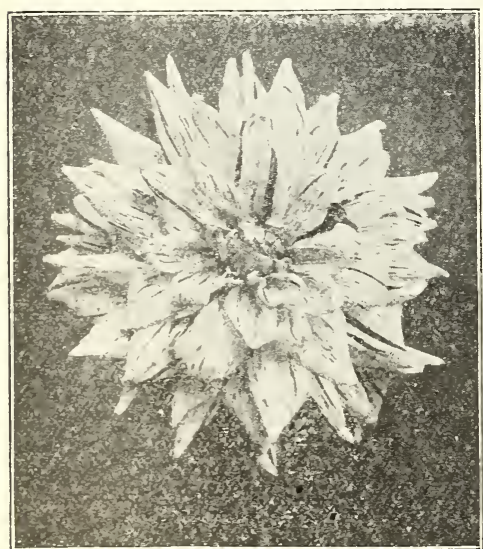

Mons. Le Normand (Decorative)
Líuvia D'Oro. Peony. Shower of Gold. Soft orange, red shaded to golden-yellow. A seedling of the popular Geisha, which it resembles in color. Flower extra large and fluffy.

Lucy Davis. Decorative. Flowers are large yet not coarse; stems are long and wiry; color rich golden-apricot, without shading. Mabel Thatcher. Decorative. Large flowers of pale yeilow shade; are borne on long, stiff stems.

Millionaire. Decorative. An immense Dahlia and among the most popular of all the extra large Dahlias. Color clear, rich orchid, shading to almost pure white in the center. Attracts instant attention.

Mons. Le Normand. Decorative. Large bold flowers borne on good stems. Color yellow, heavily streaked with red, sometimes solid red or even showing white tip.

Mrs. Carl Salbach. Decorative. Lavender-pink in color. Its immense blooms are held erect on long, stiff stems. A wonderful cut flower.

Mrs. I. De ver Warner. Decorative. Large perfect flower of charming color, a deep mauve-pink on stout stems. Free-bloomer. Naiad. Peony-flowered. A beautiful flower resembling an immense water lily. A vigorous grower; color a tinted cream-pink. Beautiful by day, and simply grand under artificial light. Stems long.

Opalescent. Peony. Flower medium to large in size, borne on excellent stems, holding the flower above the foliage. Color, varying tints of the opal shading to cream-pink. A pleasing cclor and form.

Oregon. Cactus. A large, well-formed flower with long stems. Plant sturdy in growth. Color, American Beauty-red. Very good.

Oska Geisha. Peony-flowered. Color orange to yellow. Large

Patrick O'Mara. Hybrid Cactus. One of the best autumn shades in existence, orange-buff and rose.

Paul Michaels. Decorative. Very large. A popular variety on the Pacific coast. Color old gold or orange buff. Stems slight!y pendant.

Pride of California. Decorative. An extra large fine flower of vivid red.

Rollo Boy. Cactus. Blooms are of great size carried erect on strong stems and are of a delicate shade of amber, shading to old gold. For exhibition purposes it

of the best.

Rosa Nell. Decorative. Mr. Broomall did the world a great service when he originated this hundred per cent Dahlia. The flower is immense; stem very long. Color bright rose and withal a good keeper. Highly recommended.

Ruth Jacqueline. Cactus. A strong, robust plant throwing numerous side branches. Flowers large and perfect in form. Stems exceptionally long and strong. Color clear canary-yellow. One of the very best of the yellows.

Ruth Nichols. Hybrid Cactus. Flowers are large. Color Indian-red. One of the best.

Shepherdess. Peony-flowered. Large scarlet flowers on long stems. A fine Dahlia.

Shudow's Lavender. Decorative. Huge blooms of a beautiful silvery lavender, slightly shaded white. Long, stiff stems hold flowers erect. Free and constant. sweetheart's Bouquet. Peony-flowered. In color a unique shading of salmonrose shaded with fawn.

The Grizzly. Decorative. A great dark velvety-maroon flower. Very good.

The Screamer. Decorative. Flowers very large, borne on long, rigid stems. A unique coloring, quite distinct from any other Dahlia. Color dark mulberry-red shaded to a violet purple.

Tom Lundy. Decorative. Flowers of immense size, gracefully arranged, of a brilliant carmine-red, with deeper suffusion.

Washington City. Hybrid Cactus. An immense white flower that has few, if any equals. Flowers of from 8 to 9 inches and of purest white. Stems long and equals. Flowers of from 8 to 9 inch
erect. One of the best of varieties.

william Hayden. A hybrid Cactus of immense size, 8 to 9 inches, and of shaggy formation. Stems long and wiry. Color dark velvety-red. A prolific
root maker. Among the best of the very dark colors.

\section{THE FOLLOWING POPULAR DAHLIAS ARE 25c EACH (EACH ONE LABELED)}

The assortment listed below includes the popular and standard varieties that are suitable for any garden. All
PRICES: Each 25c; $\mathbf{1 2}$ or more, all labeled, at $\mathbf{2 . 4 0}$ per dozen; postpaid, unless priced otherwise.

A. D. Livoni. Show. A beautiful, soft, lovely pink, quilled; a Charles Clayton. Cactus. Stems are long, holding the flowers

Berch von Heemstede. Decorative. Large pure yellow, long well above the foliage. Color a most intense red, so vivid as to dazzle the eye. Flowers are large in size and are produced freely. Countess of Lonsdale. Cactus. An exquisite shade of rich
salmon with a tinge of apricot at the base of the petals; freeflowering.

Black Bird. Single A distinct variety with dark purple foliage, Bon Trodung a wealth of vivid red flowers; a fine variety.

Delice. Decorative. A glowing rose-pink, long stem; one of the most popular pinks. Keeps a long time; a good cut flower. 
Popular Dahlias at 25c each-Cont’ $d$. Postpaid

D. M. Moore. Decorative. $\Lambda$ flower of mammoth size, produced in rofusion on long, stiff stems. Its color is a deep velvety-maroon. It has no equal in its color.

Eleanor Stisser. Decorative. Flowers are very large and full. A sturdy growri with long stems. Color buff, shading to pink and old rose. A pleasing antum shade. 5 feet

Flamingo. De orative. An ideal variety for cutting by reason of its fine stems and clear, rich color. Bright shell-pink.

Genesta. Cactus. Rich orange-bronze. A fine autumn shade, 3 feet.

Glori de Lyon. Decorative. Largest all pure white; a grand flower. 3 fect.

Jack Rose. Show: Brilliant crimson-red, very perfect flowers. 4 feet.

La Grande Manitou. Decorative. Varicgated, ground color, white, spotted, striped and blotched with deep violet; stiff stem; 3 feet.

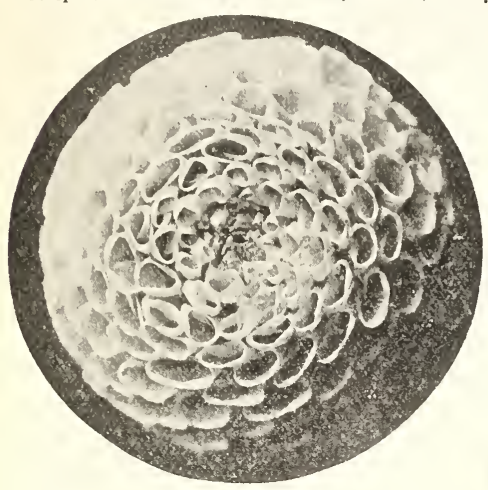

W. W. Rawson
La Jara. Peony. Pure lemon. Flower large and perfect in form. Stems Inng. A very free bloomer.

Mina Burgle. Decorative. Dark vivid red. Very free bloomer.

Mrs. M. J. Jones. Cactus. Large, rich scarlet with cream-colored edge.

Mrs. Thos. Burch. Decorative 作 shaded varieties.

Perle de Lyon. Cactus. A large cactus. Petals cleft at the tip. Pure white flower and borne on good stems. 3 feet.

Princess Juliana. Decorative. "White Delice." A superb white Dahlia, in form ?. much like Delice but longer in stem and freer in bloom.

Purple Gem. Show. A rich royal-purple, on long, stiff stems. 4 feet.

Queen of the Yellows. Decorative. Beautiful, prof use, clear yellow; early. 3 feet.

Robert Broomfield. Decorative. A grand, pure white free-bloomer. 4 feet.

Sylvia. Decorative. Soft mauve-pink, changes to white in center. 4 feet.

W. W. Rawson. Show. Pure white overlaid with delicate lavender, large, on long stems; improved Grand Duke Alexis.

\section{DOUBLE POMPON DAHLIAS}

A distinct class, producing numerous small double blossoms that keep splendidly as cut flowers. Price: $35 \mathrm{c}$ each; 3 for $\$ \mathbf{1 . 0 0}$.

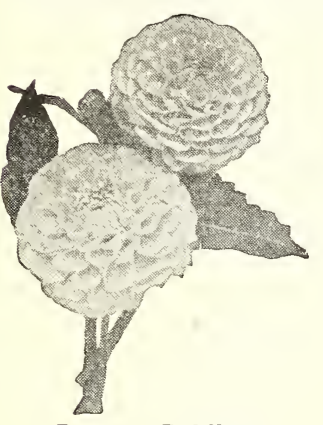

Pompon Dahlias

Achilles. Delicate lavender, tinted lilac. 3 feet

Amber Queen. Rich clear amber.

Catherine. Primrose-yellow. Well formed.

Clara Marsh. Perfect blooms of yellow; tipped with crimson.

Elegante. Quite small nink, densely quilled. 3 feet.

Girlie. Pinkish mauve.

Hedgwig Polwiz. Very free. Color red and

Isabel. Vivid scarlet. 4 feet.

Joe Pettie. Pure white, excellent variety for cutting.

Kleine Meteor. Orange-red. 3 feet.

Nora Reyrolds. Indian-red; fine.

Prince Charming. Cream, tipped with purple.

Purity. Pure white, well rounded and full. A prolific bloomer. 3 feet.

Rose of Wirmoth. Pure rose-pink. Perfect.

Winifred. White, faint purple edge.

Yellow Gem. Pure yellow of excellent form and

habit. The best of the Yellows.
Zoe. Yellow and white. 3 feet.

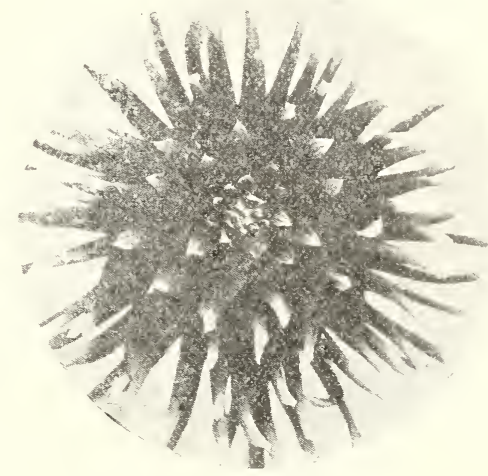

Mrs. H. J. Jones (Cactus)

\section{To Keep Dahlias As Cut Flowers}

Cut the flowers late in evening or early in the morning, not during the heat of the day. Freshly-cut flowers will keep considerably longer, and wilted flowers, if not in too serious condition, will be entirely restored in appearance if the following suggestions are followed: Cut blossoms in early part of the day whenever possible. Fill receptacle with water, as hot as can be borne by one's hand. Plunge the stems, but not the foliage, almost their entire length into the water; let them remain in the water until it cools, then transfer into cold water as in usual manner, with the addition of a quarter teaspoonful of salt to a quart of water. If the stems are particularly hard and wiry, water near boiling point may be used to good advantage.

DAHLIA STAKES See "Plant Supports" on page 49.

\section{Our Special Dollar DAHLIA COLLECTION Eight Assorted Dahlia Bulbs}

No two alike, assorted colors and types of splendid Colorado-grown bulbs. Each bulb is with one or more eyes, all ready to be planted. Our selection. Not labeled.

These will be freshly packed each week, beginning March 18th,

A very complete "Cultural Guide" leaflet with each box. Just think-

\section{Dahlias for only $\$ 1.00$ postpaid}

\section{Superb Dahlia Collection}

Eight Distinctive Tarieties

offered below which we have singled out as worthy of every Dahlia fancier's special attention. The collection contains many important recent introductions and a selection of the very best standard sorts. There are no two alike. Distinctive colors and various types. One each of eight $50 \mathrm{c}$ varieties-Our selection, labeled-

\section{Fine Dahlias for




\section{FIELD-GROWN HARDY ROSES}

Our two-year-old outdoor-grown dormant Roses are all from Western growers.

Stock is ready in March and April, at which time they should be planted. In May and later, we recommend the Hardy Roses, that are Colorado-grown, in pots.

Special leaflet, "All About Hardy Roses in Colorado," by C. R. Root, free when requested.

PRICES: Single Rose, packed and prepaid, for 75c; 5 for $\$ 3.50$; dozen for $\$ 7.50$; postpaid. Not prepaid, one or more, $65 \mathrm{c}$ each; dozen for $\$ 6.50$.

\section{WHITE}

Frau Karl Druschki. Well called the White American Beauty. It is large, beautiful snow-white, superb, very best white for outdoors.

White Killarney. Fragrant. Has long buds. Apt to mildew some; however, is very popular.

\section{YELLOW}

Sunburst. Flowers are of medium size, color is a soft yellow with orange-yellow center: a very attractive rose

Golden Ophelia. Nicely shaped buds with deep golden-apricot center. shading lighter toward edges.

Lady Hillingdon. Rather small blossom of clear light yellow.

\section{PINKS}

La France. A standard variety of silvery-rose color.

Mrs. John Laing. Soft pink of good form, exceedingly fragrant and free-blonmer; always does well.

Ophelia. Delicate tint of salmon-flesh, shaded rose, on long stem. Paul Neyren (Pink Karl Druschki). Dark-rose color of enormous size; considered the largest of outdoor roses; very hardy.

Premier. Brilliant rich deep pink flower on long stiff stems. Fragrant.

\section{REDS}

American Beauty. Bright crimson, the largest and sweetest of all hardy roses. Should be in every garden.

General Jacqueminot. A very free-growing, brilliant crimson, with fine medium large blooms; outlives many other varieties.

Francis Scott Key, Large, rich crimson flower. Free bloomer, especially in fall.

Gruss an Teplitz. Richest scarlet, shading to a velvety crimson, fragrant, strong grower and one of the best for garden culture:

\section{Hardy Climbing Roses}

Climbing American Beauty. A true American Beauty, large crimson-pink flowers on a climber. Remarkably beautiful, hardy, and saldom mildews. Illustrated in colors on front cover.

Crimson Rambler (Excelsa). Small bright crimson flowers in clusters. The most popular of all climbers. Thrives under nearly all conditions.

Dorothy Perkins (Lady Gay). Similar to Crimson Rambler, except is pink blooms.

Paul's Scarlet. Vivid scarlet, unequaled in brilliancy by any other variety; color maintained until the petals fall. Blooms are large, semi-doubleand are produced in clusters on long, strong stems, covering the bush from top to bottom, usually blooming again in the fall.

Silver Moon. White with yellow spots.

Yellow Rambler (Gardinia). Bright yellow buds opening to a creamy white.

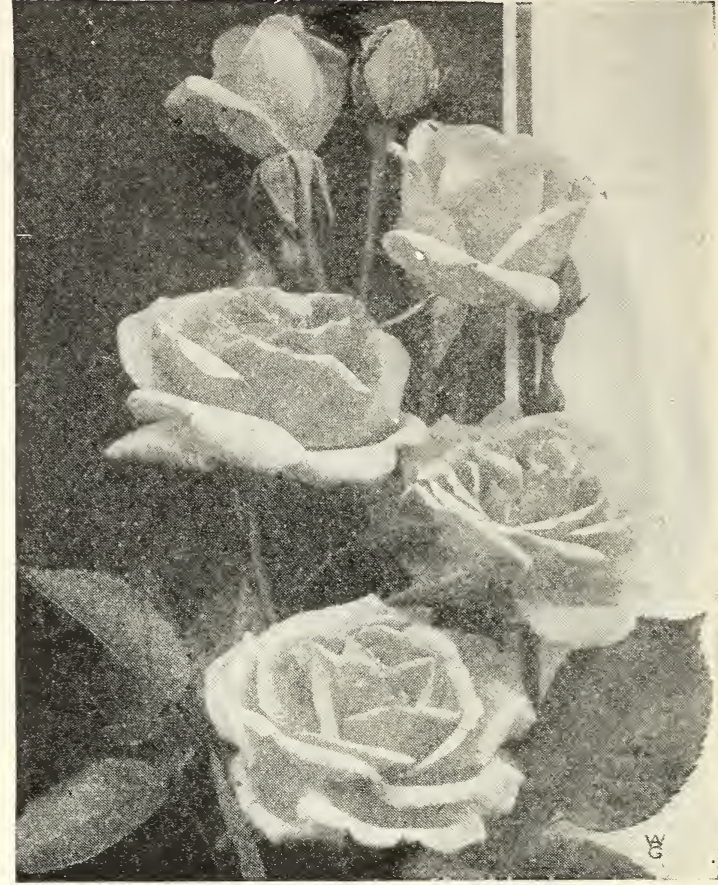

Ophelia Roses

\section{SPECIAL HARDY ROSE BUSH COLLECTION}

\section{Two-Year Field $\$ 6.00 \begin{aligned} & \text { All Deivered } \\ & \text { Grown Bushes for } \\ & \text { May }\end{aligned}$}

Includes
2 Frau Karl Druschki
2 American Beauty
2 La France
2 Sunburst
2 Gruss an Teplit
THIS COLLECTION IS POSTPAID

\section{Hybrid Rugosa Roses-THREE ESKIMO BEAUTIES The kind that grow where no others will-Pink-White-Red}

They are the ideal cold-climate roses. They are free from mildew, disease and pests that attack other classes of Roses. Once planted they are permanent; no pruning, no spraying, no suckering nor anything else is needed-just a little fertilizer and the ground stirred and they will last for years and yield an abundance of large, double, fragrant, colorful blooms - the only really good dependable Roses for very cold climate. That is why they are called Eskimo Beauties.

Belle Paitevine. The blooms are large and full; the petals gracefully incurved. Bright, clear lively pink. Sir Thomas Lipton. Pure white, no tinge of pink or yellow-just pure white. The flowers are very double and borne in graceful clusters.

Hansa. Handsome in bud and bloom. Both are large, very full and double. The color is rich maroon-

Each by Mail

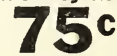

Postage Paid

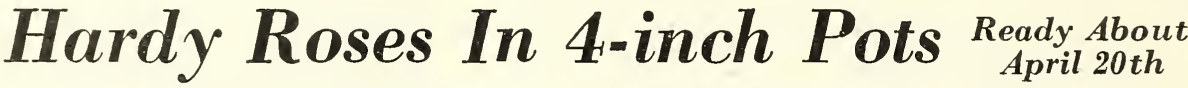

They are one year old, on own roots and are perfectly hardy. WVe do not recommend planting out until May and Tune.

For customers that call at the store we supply in the pots; but for shipping we remove the pots, wrapping paper around each.
PRICES: In 4-inch pots, Single Rose for 65c; dozen or more, one kind or assorted, for \$6.50; NOT POSTPAID. If removed from pots and sent by mail, each $75 \mathrm{c}$; dozen for $\$ 7.50$. These Roses are not ready until about April 20 th.

\section{Select Hybrid Tea Roses WHITE}

White Killarney. Very free bloomer. Fragrant. Kaiserin Augusta Victoria. Very fragrant. Medium size bud. YELLOW AND SALMON TINTS Duchess of Wellington. Yellow Killarney.
Lady Hillingdon. Clear, light yellow. Small. LIGHT PINKS

Mrs. Chas. Bell. Shell-pink Radiance.

Pink Radiance. The best light pink. Very free-blooming. DARK PINKS Briarcliff. A dark sport of Columbia.
Commonwealth. Deep rose-pink. Fragrant

\section{REDS}

Legion. A great grower, fragrant.

\section{BABY RAMBLER ROSES}

Cecil Brunner. A dagrant.

Erma Teschendorf. Best red.

\section{Climbing Roses}

White Dorothy Perkins. A very rapid grower.

Pillar Emily. Large-flowered. Light yellow.

Dr. W. Van Fleet. Delicate flesh-pink; bronze green foliage

Hiawatha. Fine in masses, single, deep rose

Bess Lovett. Resembling Climbing American Beauty, though brighter in color. A clear bright red. 
Colorado Blue Spruce

The most beautiful of all our native trees. Stock grown in this state is shipped to all parts of the U.S. Our stock is originally from the mountain forests removed to a home nursery and there given space to develop into symmetrical young trees This class is far better than where taken direct from their native halitation, beins better shape with more young root growth. All are shipped with a ball of native soil wrapped around the roots. Ready in October, also early April. Place orders in advance. Dozen lots, 10 per cent off. Cannot be mailed. Should travel by express only. Cultural leaflet free upon request, Evergreen Trees. Spruce and Cedars in the North.

Average about 24 inches tall, good shape. Each $\$ 4.00$; not prepaid.

Average about 30 inches tall, good shape. Each $\$ 5.00$; not prepaid.

Average about 36 inches tall, heavy, well shaped. Each $\$ 6.00$; not prepaid.

\section{INSPECTION}

Our Trees and Shrubbery are all properly inspected by the State Entomologist and a proper certificate of inspection accompanies each shipment.

\section{Never an Evergreen Bargain like this! EVERGREEN COLLECTIONS}

Everyone wants Evergreen Trees. Their popularity has increased a hundredfold in recent years. Use them for rockeries, foundation or lawn planting, a whole collection for the usual price of one nursery specimen. These are all twice transplanted, sturdy trees (not seedlings) average age, 5 years. Three collections listed below, delivered by Parcel Post prepaid. Safe arrival guaranteed. Delivery March 15 th to May 1st.

All shipments of these special collections are made direct to you from the Nursery.

$$
\text { Laun Collection-\$5.50 }
$$

5 WHITE SPRUCE

5 AMERICAN ARBORVITAE

5 DOUGLAS FIR

5 MUGHO PINE

Size

$8-10$ inches $10-12$ inches $8-10$ inche 6- 8 inches

Rock Garden Collection-\$4.25
8-10 inches 8-10 inches 6- 8 inches 10-12 inches 10-12 inches 10-12 inches 10-12 inche

10-12 inches

\section{Foundation Collection-\$7.25}

2 PFITZER JUNIPER,

2 MUGHO PINE

2 PYRAMIDAL ARBORVITAE

10-12 inches

10-12 inche 12-18 inche

\section{Evergreen Tree Seeds}

We are collectors of varieties indigenous to the Rocky Mountain district. Special prices for large quantities. ABIES CONCOLOR (Colorado Silver Fir). Oz. 20c; $1 / 4$ Ib. 60c; Ib. $\$ 1.75 ; 5$ Ibs. for 58.00

PSEUDOTSUGA DOUGLASII (Red Fir). Oz. 50c; 1/4 Ib. $\$ 1.50$; Ib. $\$ 4.50 ; 5$ Ibs. for $\$ 20.00$.

PICEA PUNGENS (Colorado Blue $\$$ pruce). Oz. $45 \mathrm{c} ; 1 / 4 \mathrm{lb} . \$ 1.35 ; \mathrm{Ib} . \$ 4.00 ; 5$ Ibs. for $\$ .8 .75$

PICEA ENGELMANII (Purple Spruce). Oz. 65c; 1/4 Ib. $\$ 2.00 ; \mathrm{Ib} . \$ 6.00$.

PINUS PONDEROSA (Yellow or Bull Pine). Oz. 25c; 1/4 Ib. 75c; Ib. \$2.25; 5 Ibs. for $\$ 10.00$

PINUS FLEXILIS (Colorado Limber Pine). Oz. 35c; 1/4 Ib. $\$ 1.00 ; \mathbf{I b} . \$ 3.00$.

JUNIPERUS SCOPULORIUM (Colorado Silver Cedar). Oz. 15c; 1/4 Ib. 50c; Ib. \$1.50; 5 Ibs. for \$6.25.

JUNIPERUS SABINA. Oz. 20c; $1 / 4 \mathrm{lb}$. $65 \mathrm{c}$; Ib. $\$ 2.00$.

JUNIPERUS RECLINING OR TRAILING CEDAR. Oz, 20c; 1/4 lb. 65c; Ib. $\$ 2.00$

If wanting seed of Locust, Mulberry and Osage Orange, please write us.

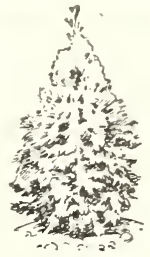

American Arborvitae

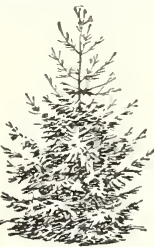

White Spruce

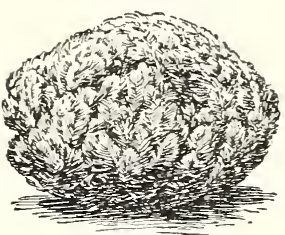

Mugho Pine

\section{Gazing Globes}

Give new charm to your garden and add beauty to the lawn.

Let a Gazing Globe reflect the moving clouds, and birds, you will then be charmed with the small investment. 10 -inch Silver Globe (no pedestal) $\ldots \ldots \ldots \ldots \ldots \ldots \ldots \ldots \ldots \ldots \ldots \ldots, \$ 10.00$

12-inch Silver Globe (no pedestal) .

14-inch Silver Globe (no pedestal)

NET F, O, B. DENVER.

\section{Sun Dials}

Made in bronze, ready to be mounted. Made adjustable to different locations and to the season,

Nurserymen using quanti ty of Evergreen Tree Seeds should contract with us in advance.

No. 11

Plain metal, green, 11-inch

Brass Plated, 11-inch.

4. 5

NET F: O, B: DENYER.

\section{Garden Elfs}

Ask for cir cuear that il lustrates and describes Gazing Globes and Sun Dia's.

Durable weather-proof plaster composition; very interesting and lifelike reproductions in various pcses of the fairy story Elfrs. Highly colored and when used in rock gardens, around lily pools and other garden spots are very interestirg. Height 10 to 18 inches, Price-\$1.25 to $\$ 4.75$ each: not postpaid.

IRON ORNAMENTS. White Rabbit, pink eye; $\$ 1.85$, 


\section{Hardy Flowering Shrubs \\ These play}

planted extensively; they are ornamental even when not in bloom.

Our stock is all field-grown, two years old, well rooted, $21 / 2$ to 4 feet tall, usually too large or mailing; express is always best. If must go by mail they can be trimmed back.

This stock is packed and shipped by our own experienced men. Every article is with life when it leaves us. The task to success is then up to you. We can not guarantee it further. Cultural leaflet free upon request.

Transplanting and Managing Trees, Shrubs and Vines. Suitable information when planting extensively.

ALMONDs. Produce rosette-like flowers early in spring before the leaves appear. Are dwarf, bushy and compact. Double pink. Each \$1.00; by mail \$1.15.

ALTHEA (Rose of Sharon). Bush. The blossoms are double, coming on in August until in September. Can supply red and pink. Each 60 c; by mail 75 c

BEAUTY BUSH. An exceedingly handsome new ornamental shrub from the wilds of China resembling Honeysuckle. Long arching branches combined with hardiness and year-around beauty of foliage and habit, and an amazing profusion of pale pink bell-shaped flowers in June, make this a perfect shrub. Each $\$ 1.25$; by mail $\$ 1.50$.

BERBERIS (Japan Barberry). Suitable for lawn or border. In fall the bright red berries $83 c$; by ma:I $\$ 1.00$.

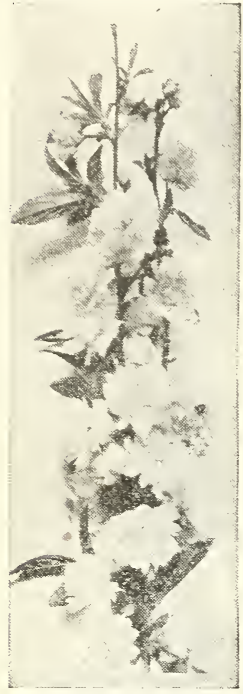

Flowering Almond
BUTTERFLY BUSH (Buddleya or Summer Lilac). The flowers are like spring lilacs, and come on in great profusion in July. Butterflies enjoy sporting among the blooms. Dies down each season. Each 50 ; by mail $60 \mathrm{c}$.

CALYCANTHUS (Strawberry Shrub). An old favorite, producing double chocolate-colored, strawberry-scented flowers in June. Each $\$ 1.00$; by mail $\$ 1.15$.

DOGWOOD (Siberica). Ours is the true, red bark with white flowers, so much desired. Each $50 \mathrm{c}$; by mail $60 \mathrm{c}$.

DOGWOOD (Lutea). The yellow-bark variety. Otherwise similar to the Siberica. Each 50 c; by mail 60c.

FLOWERING CRAB (Bechtel's). The blooms are in a mass of delicate pink, of delicious fragrance. Very much admired; select specimens; 2 to 3 feet. Each $\$ 1.25$; by mail $\$ 1.50$.

FORSYTHIA FORTUNEI (Golden Bell). Bears small yellow flowers, very early, before leaves appear. Each 60 c; by mail $75 \mathrm{c}$.

GOLDEN ELDER. Golden-yellow foliage all the season. Very suitable where color effects are desired. Each 75c; by mail 90c.

HIGH BUSH CRANBERRY. Produces numerous small white flowers in June, followed in fall by bright scarlet berries in clusters. Grows like Snowball. Each $\$ 1.00$; by mail $\$ 1.20$.

HONEYSUCKLE (Bush Tartarian). Very bright flowers leaving quantities of red and orange berries. Can furnish Pink and White. Each 60 c;
by mail 70 c.

HYDRANGEA (Paniculata Grandiflora). Produce massive white flowers, then pink, afterwards are reddish-bronze and green, from August till autumn; 2 to 3 feet. The blossoms may be cut and used for winter dry flowers. Plant in shade. Each $85 \mathrm{c}$; by mail $\$ 1.00$.

JAPAN QUINCE (Fire Bush or Flowering Quince). In early spring, before foliage is out, the cherry-red flowers literally cover the branches. After the blooms fall, a
Each 80 c; by mail $\$ 1.00$

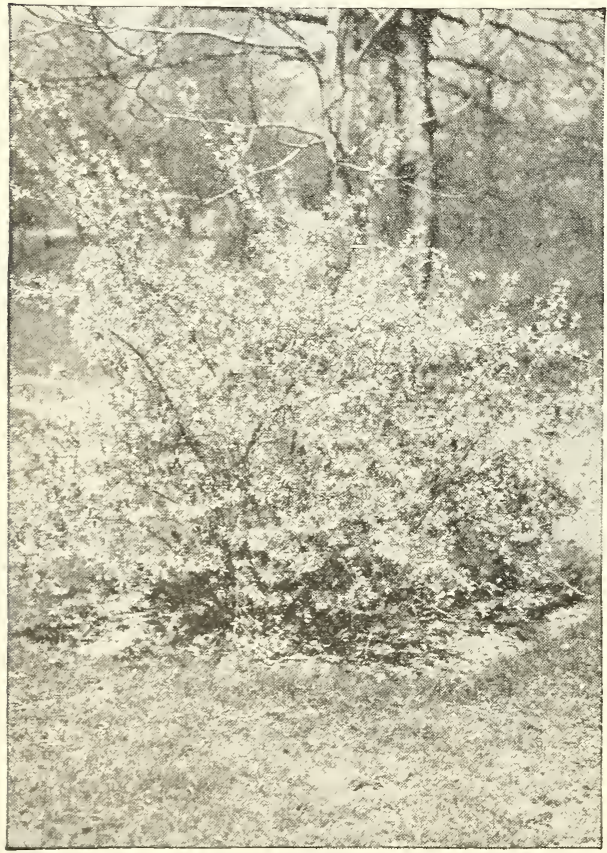

Forsythia Fortunei
Send in your orders early for Shrubs and Hardy Plants. They are then sent out soon as weather is suitable. You get them when they will do best.

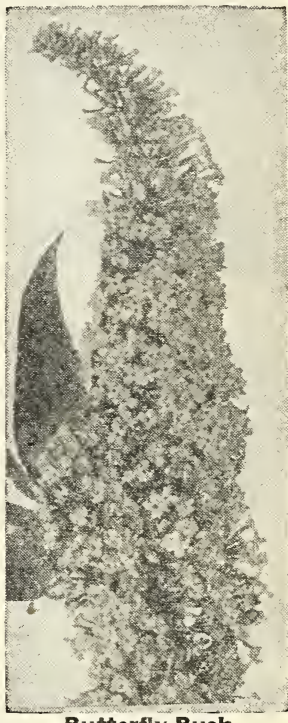

Butterfly Bush

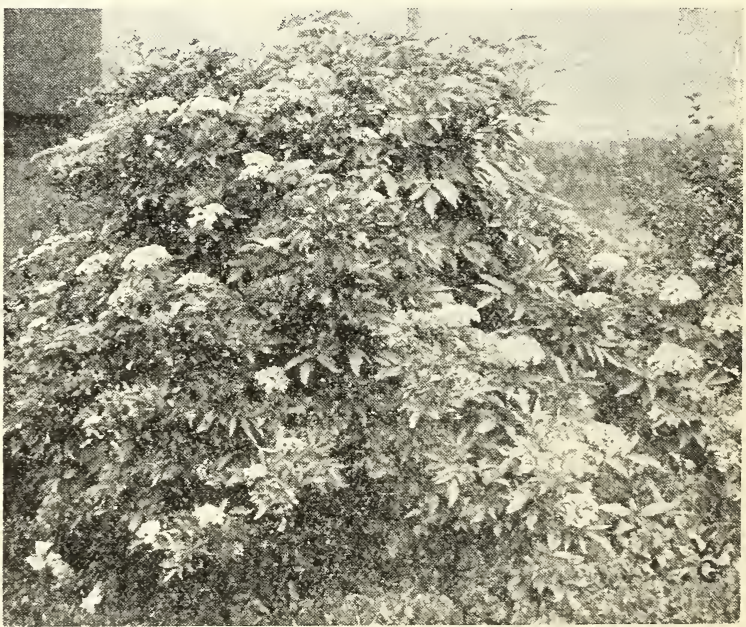

Golden:EIder 


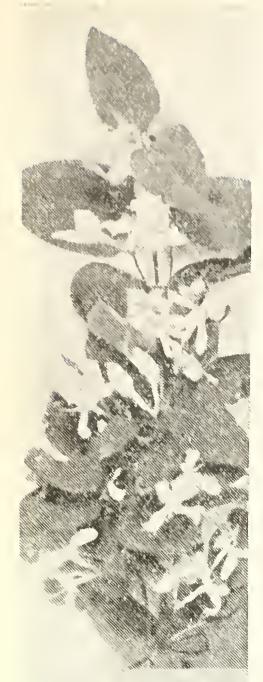

HONEYSUCKL.E

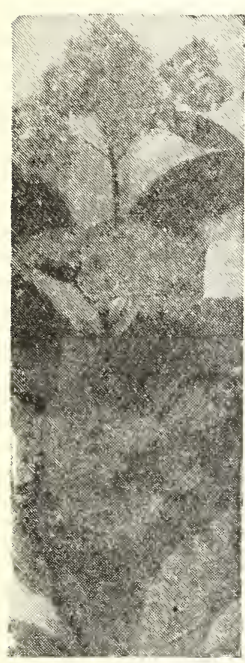

Spirea (Anthony Waterer)

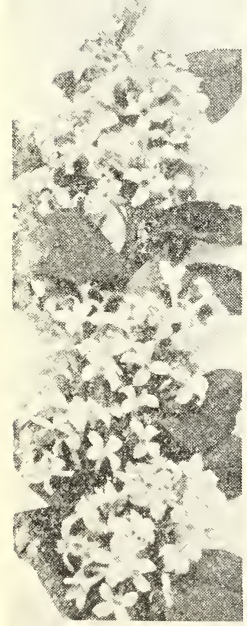

PERSIAN LULAC
LILAC (Common). The posular extra hardy

Purple. Each 50c; by mail 60c.

White. Each $90 \mathrm{c}$; by mail $\$ 1.00$.

LILAC (Persian). The blossoms are a redisli mon. Each $\$ 1.00$; by mail $\$ 1.15$.

LILAC (French). Very hardy, carly, and Alphonse Lavelle. Double violet. Charles Jolly. Double, dark purplish-red. Mme. Lemoine. Double pure white. Each \$2.00; by mail \$2.25.

MOCK ORANGE (Philadelphus, Grandiflora). This variety of the syringea is per fectly hardy, grows tully 8 feet and produce creamy-white sweet-scented flowers in abundance. Splendid for background. Each 60c by mail $75 c$.

BRIDAL WREATH (Spirea Van Houttii). This very popular flowering shrub needs very little description, since it is probably the most popular shrub, and one of the very easy to cultivate. We have it in three sizes to suit all purposes; however all ar the true white flowers.

Small Size. Average 18 to 24 inches. Very suitable where planting as hedge. Each 40c; by mail 50c. Doz. $\$ 4.00$; by mail \$4.50.

Standard Size. 3 to 4 feet, well branched. Each 60c; by mail 75c.

Large Size. As a clump, 4 to 5 feet. Each $\$ 1.00$; prepaid $\$ 1.35$.

SPIREA (Anthony Waterer). A dwarf bush with dense foliage and bright crimson blooms throughout the summer. Each 80c; by mail 90c.

SPIREA FROEBELI. Of the Anthony Waterer type, but more sturdy in habit. The growth is distinctly red with roseSPIREA THUNBERGII. A beautiful feathery foliage and pure white flowers coming
very early, like Bridal Wreath. Each 70c; by mail $80 \mathrm{c}$.

SNOWBALL (Common). Produces numerous white ball-like flowers in May. Usually in time for Decoration Day. Each $80 \mathrm{c}$; by mail $90 \mathrm{c}$.

SNOWBERRY (White). In June produces numerous small rose-colored flowers which are followed with creamy-white berries that remain half the winter. Each 50 c; by mail $60 \mathrm{c}$.

RED SNOWBERRY. Being similar to the white excepting color of berry; often called Indian Currant. Each 50c; by mail 60c. SUMAC (Glabra). A spreading shrub much admired for the beautiful brilliant foliage in fall. Each 60c; by mail 75c.

TAMARIX (Tetrandra P.). Tall-growing with fine feathery foliage and soft pink flowers in July and August. Called Feather Bush. Each 50c; by mail 65c.

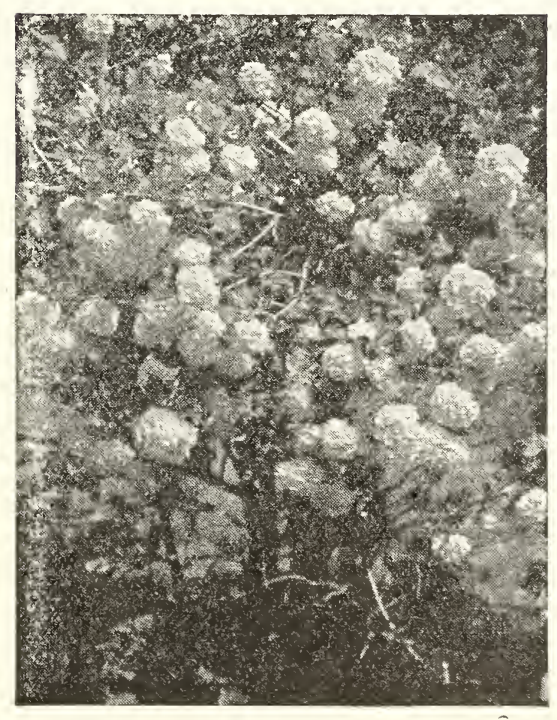

Snowball

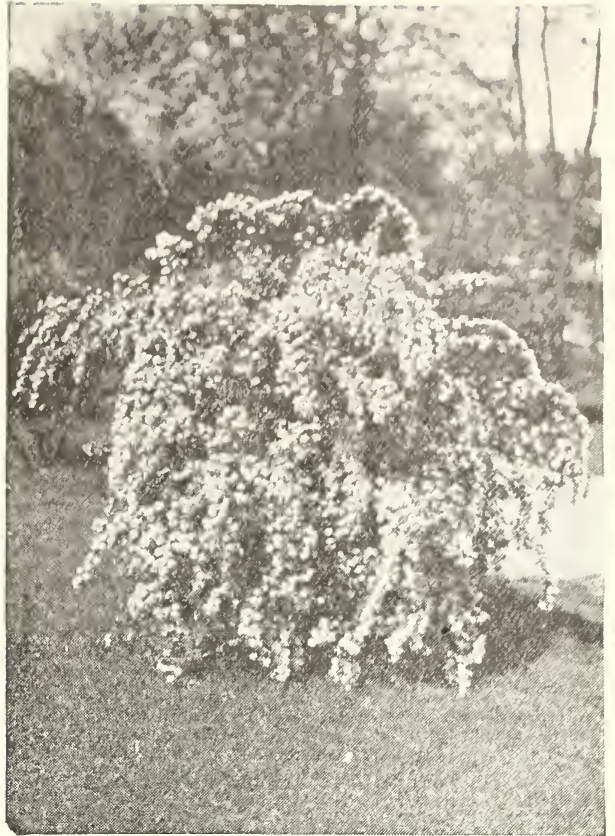

Bridal'Wreath (Spirea Van Houttii)

\section{Special Shrub Offer}

Four Splendid Shrubs of Special Merit-All Delivered, Postpaid,

1 Spirea"Bridal Wreath

1 Forsythia Fortunei (Golden Bell)

1 Mock Orange

for

1:Go!den Elder

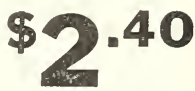

Include in Your Order a Collection for a Friend

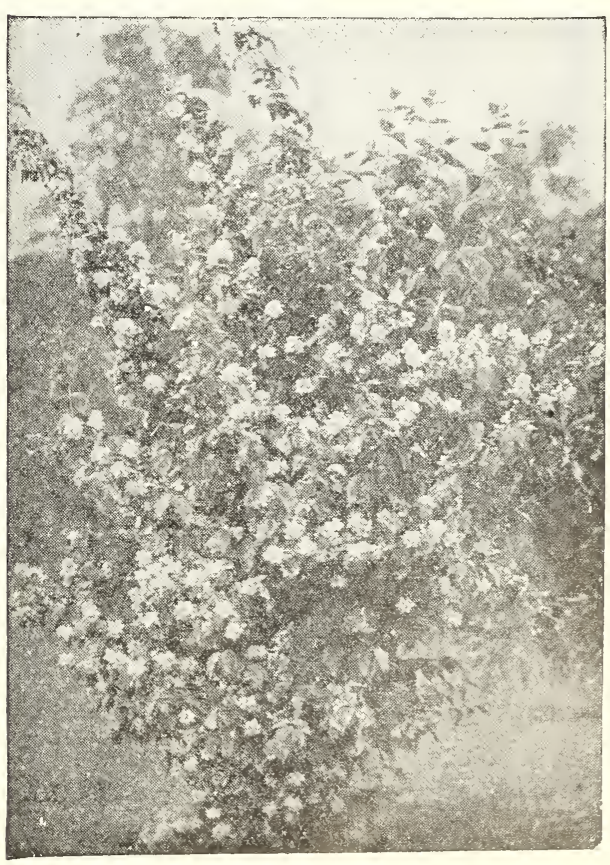

Mock Orange 


\section{Hardy Hedge Plants}

We recommend only varieties that are hardy and thrive in Colorado. There really are but few varieties that are suitable.

\section{HARDY PRIVET}

The true AMOOR RIVER NORTH stock of Siterian variety, acclimated here, thrives and makes handsome hedge. Our stock is 18 to 24 inches. Should be planted 6 in. to 10 in. apart. Doz. $\$ 1.50 ; 100$ for $\$ 10.00$; prepaid for $\$ 12.00$.

The California Privet is not hardy in Colorado.

\section{BARBERRY}

JAPANESE THUNBERGIA. Makes excellent low hedge and very desirable as a shrub; stock is 3-year-old, 15 to 18 inches high. Each 20 c; by mail 30 c. Doz. $\$ 2.00$; prepaid $\$ 2.50$.

NEW RED-LEAVED JAPANESE BARBERRY. Similar in all respects to the green-leaved Japanese Barberry, which is so popular for mixing in the shrubbery border. but the foliage is of a rich, lustrous, bronzy-red, similar to the richest red-leaved Japanese Maples. It becomes more brilliant and gorgeous throughout the summer. and in the fall its foliage changes to vivid orange, scarlet, and red shades. All that is required to develop its brilliant coloring at all seasons is that it be planted in full exposure to the sun. Each $65 \mathrm{c}$; by mail $75 \mathrm{c}$.

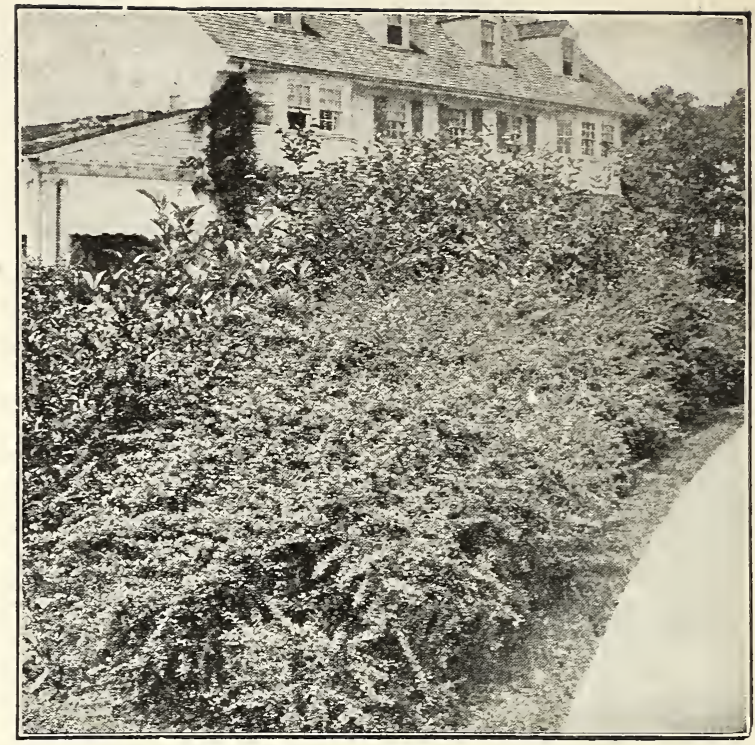

New Red-Leaved Japanese Barberry in foreground

\section{Hardy Climbing Vines}

There are many places around every home where vines can be used with satisfaction-on arbors, trellises, fences, stumps, etc. Do not overlook their importance. Cultural leaflet free upon request. Climbers, Hardy. From roots and tubers for spring planting. AMPELOPSIS ENGELMANNI (Clinging Ivy). Is very quick-growing. Its glossy, light green foliage clings to brick, stone or wood, changing to a beautiful crimson in fall. Usually free from insects. Is far better than Boston Ivy in this climate. The first year it seldom $\$ 4.20$; by mail $\$ 4.50$.

AMPELOPSIS ViaITCHI (Boston Ivy). A very popular climber in the East for coverin brick, walls, trees, etc. Slower than Engelmanni. Each 75 c; by mail 80 c.

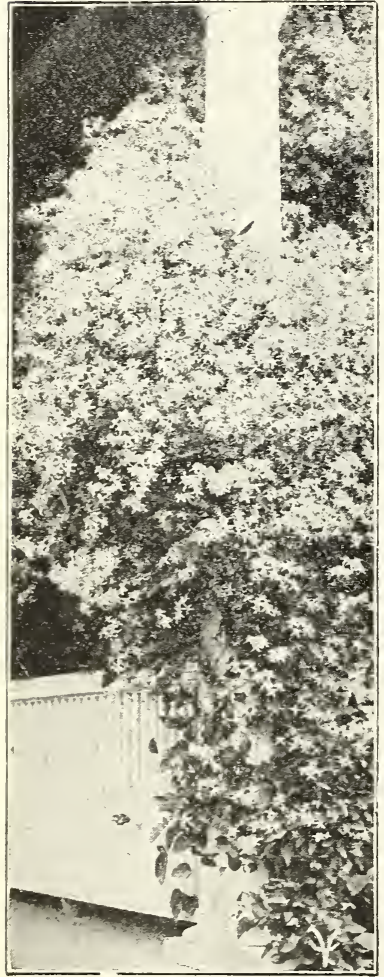

Clematis Paniculata
Try $\star$ VYN-TACH Hooks

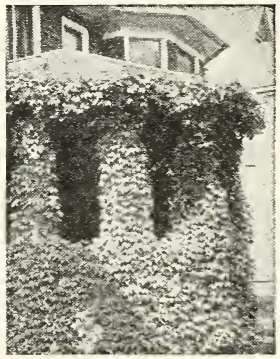

For al! kinds of vines and climbing

Roses, for on wood or on masonry.

See page 49

to

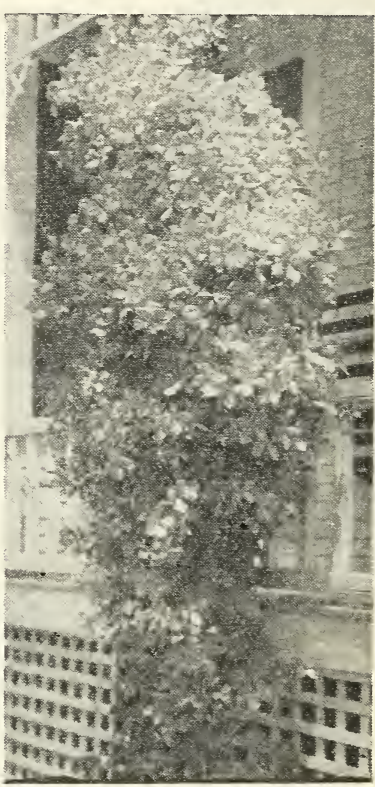

Clematis Jackmanni

AMPELOPSIS QUINQUEFOLIA (Virginia Creeper). This common woodbine is useful on fences and arbors. Thrives anywhere. Each 20c; by mail 25c. Doz. \$2.00; by mail 52.25.

BIGNONIA RADICANS (Trumpet Vine). A vigorous climber with trumpet-shaped crimson-orange flowers. It clings to walls. Each $50 \mathrm{c}$; by mail $60 \mathrm{c}$.

BITTER SWEET. An old popular climber with glossy foliage and large clusters of orangecrimson berries that remain all winter. These berries are much admired for winter indoor decoration. Keeps well. Each 60 c; by mail 70 c.

CLEMATIS (Large Flowering). No other climbing plant equals in attractiveness these beautiful large-flowering Clematis. They need rich deep soil, perfect drainage though abundance of water. Their requirements are peculiar, and even then they will die occasionally. Be sure that the roots are properly spread out and earth comes in contact up under center of crown roots. Special instructions given with each purchase when asked for. Jackmanni. Violet-purple, intensely colored, giant blooms-the grandest of all Clematis. Each $\$ 1.00$; by mail $\$ 1.15$.

Clematis, in 4-inch pots. These are fine looking stock, all growing with 10 to 15 inches of healthy growth. All ready to set out. Each $\mathbf{\$ 1 . 5 0}$, for local trade. Not convenient to ship. CLEMATIS PANICULATA (Japanese Virgin Bower). Quite different from the above varieties. It blooms in fall with numerous small white star-like flowers that are especially by mail $60 \mathrm{c}$.

Cle matis Coccinea. This is the old much admired coral-flower blossom. The blossom is red outside, cream color inside. Very ornamental. Each 60 c; by mail 70 c. 
IIardy Climbing Vines, Continued

CINNAMON VINE. Free-growing, with small white, fragrant flowers, green, glossy, heartshaped leaves. Not a dense foliage but very
attractive. Each 10c; doz. $\$ 1.00$; postpaid.

DUTCHMAN'S PIPE. Has enormous leaves and produces brownish-colored flowers resembling a most satisfactory. Each $\$ 1.00$; by mail $\$ \mathbf{1 . 1 5}$. HOP VINE. The common hop makes a splendid covering for fences, rocks, etc. Bears a profusion of hops. Roots

HONEYSUCKLE, HALLEANA (Hall's Japan). Yellowish-white flowers changing to yellow. Very fragrant and free-bloomer. Each 50c; by mail, $60 \mathrm{c}$.

HONEYSUCKLE (Scarlet Trumpet). Hardy with trumpet-shaped flowers continuing all summer. Each 50c; by mail 60c.
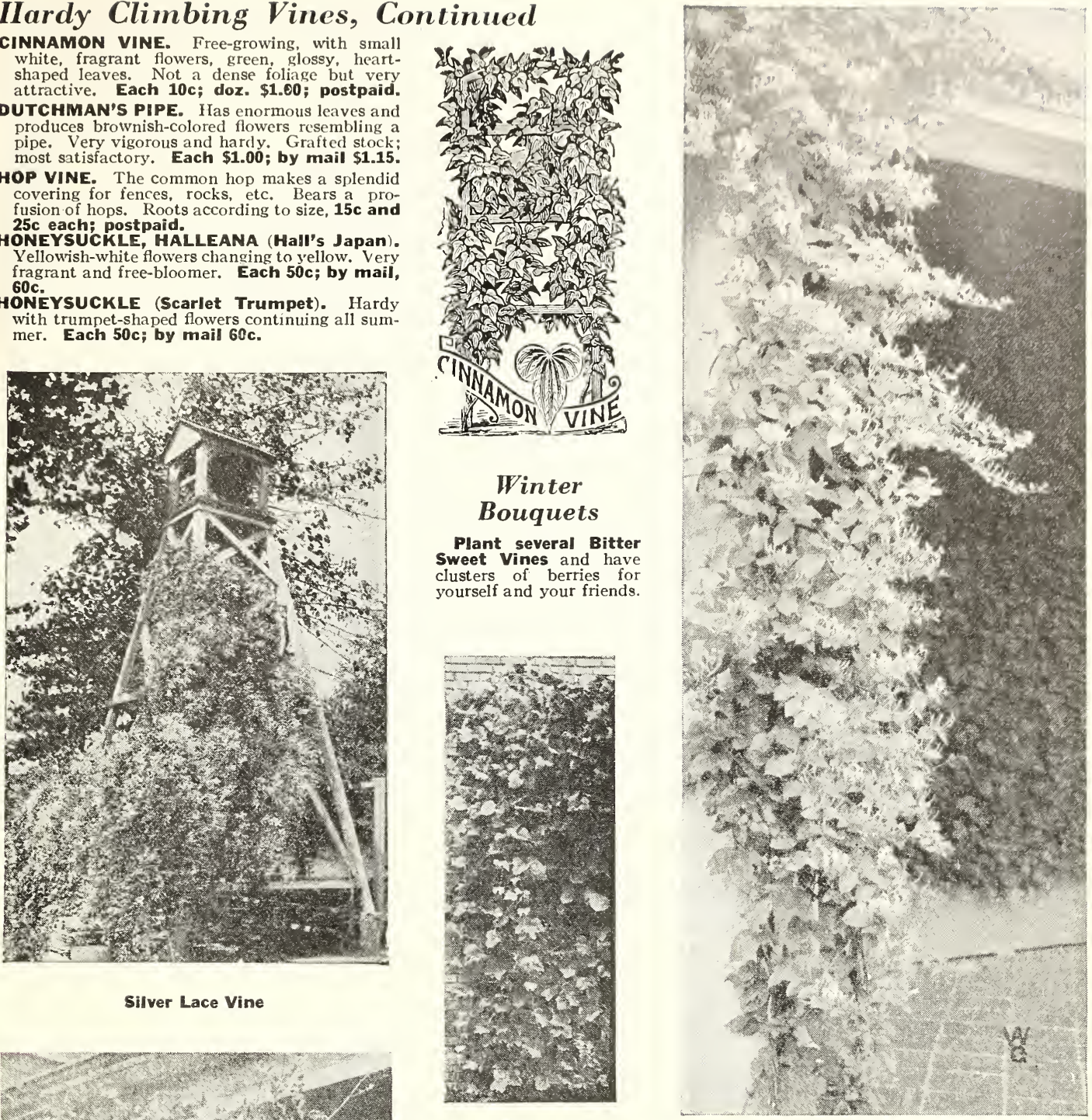

Silver Lace Vine

\section{Winter \\ Bouquets}

Plant several Bitter Sweet Vines and have clusters of berries for yourself and your friends.

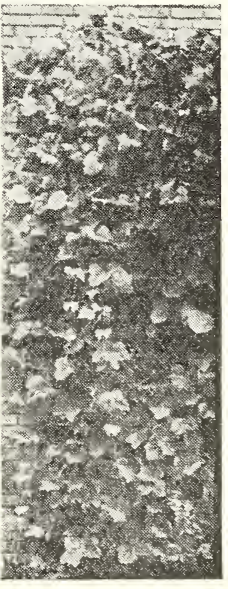

Kudzu Vine
Honeysuckle, Halleana (Hall's Japan)

HONEYSUCKLE (Heckrotti). Has dark rich red and creamy yellow blossnms Blooms continually the whole season. Is especialiy desirable. Each 60c; by mail $70 \mathrm{c}$.

KUDZU VINE. Grows wonderfully fast, producing large thick leaves that make excellent porch shade. Small rosy-purple flowers in late summer. Usually hardy in Colorado. Large roots, $40 \mathrm{c}$ each; by mail 50 c.

LATHYRUS LATIFOLIA (Perennial Flowering Peas). The popular perennial flowering pea, called Hardy Sweet Pea; however, they have no fragrance. Usually supply pink and crimson. Roots $25 \mathrm{c}$; doz. clumps $\$ 2.50$; postpaid. MADEIRA VINE. This old-fashioned popular vine is not hardy, though we place it in this list. Our tubers are Colorado-grown. Average size: Each 10c 3 for 25 ; 12 for $90 \mathrm{c}$. Small-size tubers: 3 for $15 \mathrm{c}$; 12 for $60 \mathrm{c}$; all postpaid. MATRIMONY VINE. A very dense and vigorous climber that overcomes al obstacles. Somewhat shrubby in nature, but will climb fences, trellises, rocks, SILVER OCE VINE nkment. Small white fowers. Each 35 ; by Is a vigorous small creamy-white flowers through summer and fall. Very satisfactory. Each 90c: by mail $\$ 1.00$

WISTARIA. Slow-growing, twisting vine with pea-shaped blossoms.

supply in Purple blossom only. This season we have the grafted stock which is more sure to bloom. Each $93 \mathrm{c}$; by mail $\$ 1.00$.

Plant vines in assortment; they all blend wonderfully and as they. flower at different times the effect is continuous. 


\section{BERRIES- FRUIT}

These varieties are all of established merit and very suitable for our Western planters. Our stock is all examined by State Inspectors.

IVe do not claim to grow this stock. We do, however, claim to have it grown for us by very rester honest in giving us the best they can produce.

Let us book your orders early and ship the stock as wanted. No extra charge for packing.

\section{ABOUT GUARANTEE AND REPLACEMENT}

While we cannot guarantee every plant or root to live, we do guarantee that each is in good condition when packed and shipped. Part of this risk is yours in giving proper care and culture. If ever there is a fault you think is ours, write us frankly; we will do our part. IVe must have our customers satisfied.

So much depends on the care in protecting the roots from exposure, delay in planting, careless planting, unfavorable weather conditions, thus consideration on purchaser's part will show that to replace all losses is injustice to us. Thus when there is an actual loss we replace at Half Price. Cultural leaflet free upon request.

BOOK-"Grow Your Own FruitEat It, Can It, Store It."

84 pages of good information with illustrations. Just what every suburban home owner should know. Free with an order for $\$ 2.00$ worth or more of small-fruit plants. Sells for 15c.

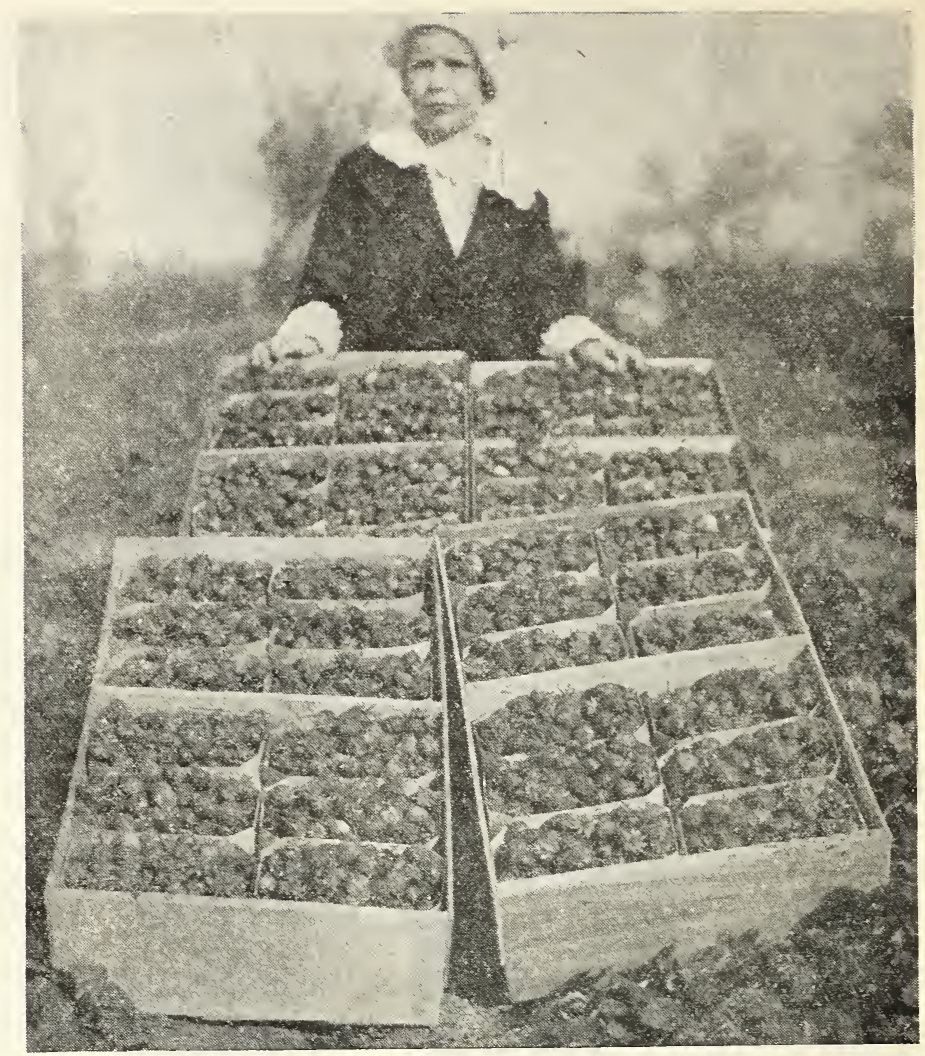

Grow your own-they're better

\section{STRAWBERRIES-Fall Bearing}

\section{We pay postage on Strawberry Plants and Small Fruit at these prices}

Bur one-year-old plants and get them into the ground as soon as you can. Before planting, dip the roots in water. Set the plant with the crown or bud at the surface of the ground. April and early May is the best time to set the plants. If late May or June, the leaves should be trimmed. We do not recommend fall planting.

Everbearing varieties are now the leading kinds-in fact, so much can be said in favor of varieties that produce all through the summer and fall that we are discarding so-called Standard or June varieties and offer Everbearing varieties oniy.

For best results with Strawberries, give all-day sunshine and apply nitrate of soda or fine bone-meal fertilizer in June.

Mastodon. The best Everbearer known. The giant of all Everbearing. Produces heavily in July, then renews its productivenes in August and continues until freezing-up time. In late October last season we enjoyed boxes of these large delicious berries. The berries are very large, firm and uniformly well colored. Tests have been made where 18 berries filled a quart box. Three berries weighed 2 ounces. They have a very fragrant aroma. This is the coming strawberry. 25 plants for $\$ 1.00 ; 100$ plants for Champion. The fruit is of medium size, and blunt or wedge-shaped. Glossy red color, juicy and firm. of good flavor. Is a good postpaid.

Progressive. This desirable variety has been in cultivation in Colorado for several seasons. Is not a large berry but produces conpostpaid,

Superb. An Everbearing variety of introduction after the Progressive. Is larger berry but hardly as rich. A strong grower and produces well. 25 for $60 \mathrm{c} ; 100$ for $\$ 1.50 ; 1,000$ for $\$ 12.00$; postpaid.

\section{CURRANTS}

\section{2-YEAR-OLD PLANTS}

CHERRY. Large, deep red, medium producer. Single plant $25 c ; 10$ for $\$ 2.00$.

PERFECTION. Very large, best red currant on market. Single plant $30 \mathrm{c} ; 10$ for $\$ 2.50$.

WHITE GRAPE. Creamy-white, medium size, mild. Single plant 25c; 10 for $\$ 2.00$.

\section{RASPBERRIES}

ST. REGIS EVERBEARING. Produces beautiful red berries from June into September; a truly eariy and late variety. The "St. Regis" is in Raspberries what "Progressive" is in Strawberries. Single plants $15 \mathrm{c} ; 10$ for $70 \mathrm{c} ; 100$ for $\$ 4.00$

LATHAM. A new large red. Exceedingly hardy and a good shipper. Single plant $15 \mathrm{c}: 10$ for $90 \mathrm{c} ; 100$ for $\$ 5.00$. GREGG. Large black-cap; very productive (tips). Single
plant 15c; 10 for $60 \mathrm{c} ; \mathbf{1 0 0}$ for $\$ 3.50$.

\section{BLACKBERRIES}

SNYDER. Medium size, very hardy and early. Single plant $15 \mathrm{c} ; 10$ for $70 \mathrm{c} ; 100$ for $\$ 4.50$.

RATHBURN, Large, sweet and juicy, jet-black Single plant $15 \mathrm{c} ; 10$ for $70 \mathrm{c} ; 100$ for $\$ 4.50$.

According to the latest classification of the Railway Express Agency, Seeds, Bulbs, Roots and Tubers take 2 nd class rate,

\section{GOOSEBERRIES}

DOWNING. Large, pale green, very sweet, hardy. Seldom mildews. Single plant $25 \mathrm{c} ; 10$ for $\$ 2.00$.

HOUGHTON. Pale red, medium size, very prolific. Single plant 25c; 10 for $\$ 2.00$.

\section{GRAPES}

Grape culture in Colorado invites more attention than has been given. The following hardy varieties do well, especially on the south and east slopes of our hillsides.

CONCORD. Standard black, very hardy; best for Colorado. Each $20 \mathrm{c} ; 10$ for $\$ 1.50$.

MOORE'S EARLY. A popular early black, larger than Concord Each $30 \mathrm{c} ; 10$ for $\$ 2.50$.

BRIGHTON. Fine large berries; the best dark red for the West. Each $30 \mathrm{c} ; 10$ for $\$ 2.50$.

NIAGARA. A popular white; large bunches; tough skin. Each $30 \mathrm{c} ; 10$ for $\$ 2.50$.

\section{GRAPES FOR ARBORS}

Fach 35c 3 for $\$ 1.00$ which averages $25 \%$ less than the regular rates. 


\section{Vegetable Seeds “Dependable Grade"}

$\|$

Our Specialty to Encourage Economical Buying

Six 5c Packets, any kind, for 25c. Three 10c Packets, any kind, for 25c.

Two $15 \mathrm{C}$ packets for 25c. As many packets as you select on this basis;

thus always purchase at least $25 \mathrm{C}$ worth or more of seed in packet.s.

FREE GARDEN BOOK - 80-page book, illustrated and full of information. “MAKE THE GARDEN PAY." This is worth dollars to any home gardener. It is free with orders for $\$ 2.00$ worth or more of Vegetable or Flower Seeds. if asked for when order is sent in. Leaflet free with all orders when requested. Vegetabie Garden Culture. Brief suggestions.

Ill Garden Seeds Postpaid

\section{ARTICHOKES}

One ounce will produce 500 plants

GREEN GLOBE. Large; heads are used; require long season. Pkt. 10c; Oz. $60 \mathrm{c} ; 1 / 4 \mathrm{Ib}$. $\$ 1.80$.

\section{ASPARAGUS}

\section{One ounce for 60 feet of row.}

Asparagus is a slow grower, requiring at least three years to mature from seed, and is therefore not generally recommended to the small gardener. Usually unless you go into asparagus raising on a large scale. that you get the roots in preference to raising from seed. Cultural leaflet on request. Asparagus. How to have your own Asparagus bed.

Mary Washington Rust-Proof. Is green with pinkish tint at bottom. Our seed is direct will eventually supersede all other varieties. Pkt. 5c; oz. 20c; $1 / 4 \mathbf{I b} .60 \mathbf{c} ; \mathbf{I b}$. \$1.75.
EARLY GIANT ARGENTEUIL. True green. Pkt. 5c; oz. 10c; 1/4 Ib. 25c; Ib. 65c.

PALMETTO. Large green, very popular. Pkt. 5c; oz. $10 \mathrm{c} ; 1 / 4 \mathrm{Jb} .25 \mathrm{c} ; \mathbf{I b}$. $60 \mathrm{c}$.

\section{ASPARAGUS ROOTS}

We recommend the Mary Washington Rust-Proof. 1-year-old Roots. 2-year-old Roots.

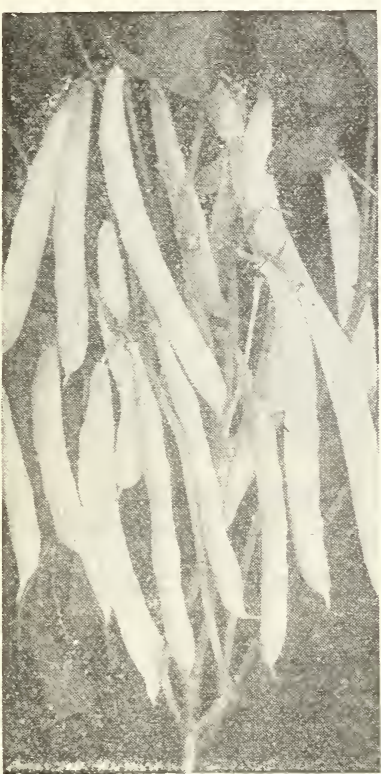

Doz. 35c; per $100 \$ 1.25$; postpaid Doz. 45c; per $100 \$ 1.50$; postpaid

\section{BEANS, GARDEN-DWARF}

One pound will plant 100 feet, 60 pounds an acre

the vines in damp weather. Bean crop very short.
When Bean Beetles trouble, pick off all you see, then use Arsenate of Lead.

NITRAGIN INOCULATING BACTERIA will increase your Bean crop. Trial size 25c; $1 / 4$-acre size $40 \mathrm{c} ; 1 / 2$-acre size $60 \mathrm{c}$; acre size $\$ 1.00$; all postpaid.

SEMESAN. The Premier Disinfectant-will do much toward increasing your crop of Beans and prevent blight. Ask for free

leaflet. 2 ozs, 50c; Ib. $\$ 2.75$. Cannot be mailed.

\section{GREEN PODDED VARIETIES} Pkt. $5 \mathrm{c} ; 1 / \mathrm{Ib} .10 \mathrm{c} ; 1 / 2 \mathrm{lb} .15 \mathrm{c}$; Ib. 30c; 2 Ibs $55 \mathrm{c}$. pods of rich green color. Pkt. 5c; $1 / 4 \mathrm{Ib}$. 15c; $1 / 2 \mathrm{lb}$. 25c; Ib. $40 \mathrm{c} ; 2 \mathrm{lbs}$. $75 \mathrm{c}$. $1 / 2$ Ib. 25c; Ib. 40c; 2 tbs. 75c. $1 / 2$ Jb. 20c; Ib. 35c; 2 Ibs 70 c. 20 ; Ib. 35c; 2 Ibs. $65 \mathrm{c}$.

\section{YELLOW PODDED VARIETIES} Ib. $45 \mathrm{c} ; 2$ Ibs. $85 \mathrm{c}$ Pkt. 5c; $1 / 4$ lb. $15 \mathrm{c} ; 1 / 2 \mathrm{lb} .25 \mathrm{c}$; Ib. $45 \mathrm{c} ; 2$ lbs. $85 \mathrm{c}$.

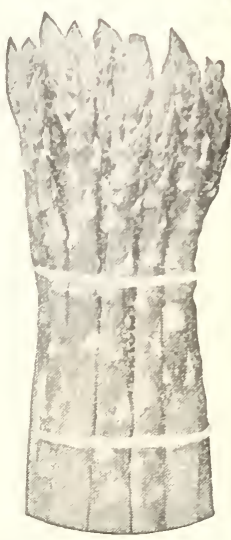

Mary Washington Rust-Proof

Bush Beans should be planted about the last of May. The furrows should be at least two feet apart. A pound of wood ashes should be hoed into every ten feet of furrow, leaving the furrow not more than an inch deep. Plant the Beans four inches apart in the furrow and cover them with an inch of soil. They come up in from 8 to 10 days, and the plants mature in from six to nine weeks. Thorough tilling is essential; the ground must be kept soft. Avoid handling or touching

Stringless Green Pod Early, round pod, tender and productive. Best variety IMPROVED RED VALENTINE or SHIPPER'S GREEN-POD. Round curved pod, prolific.

FULL MEASURE. A dependable early stringless green pod, especially suitable for Colorado.

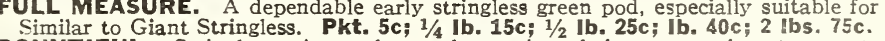

BOUNTIFUL. Stringless. A popular market variety, being very resistant to rust. Immense

BROAD WINDSOR. Pods grow upright; hardy; popular shell bean. Pkt. 5c; 1/4 lb. 15c;

BURPEE'S IMPROVED BUSH LIMA. Very large seed, 4 to each pod. Pkt. 5c;1/4 Ib. 10c;

HENDERSON'S BUSH LIMA. Small seed, early, erect grower. Pkt. 5c; $1 / 4$ Ib. 10c; $1 / 2$ Ib.

GOLDEN WAX. Flat pod, very productive and very tender. Pkt: $5 \mathrm{c} ; 1 / 4 \mathrm{Ib} .15 \mathrm{c} ; 1 / 2 \mathrm{Ib} .25 \mathrm{c}$;

Brittle Wax (Round Pod Kidney Wax). Best wax variety, big yielder, round pods.

LACK WAX (Pencil Pod). Best black, very early, heavy cropper. Pkt. 5c; $1 / 4 \mathrm{Ib} .15 \mathrm{c}$;

Golden Wax

\section{POLE BEANS}

Prepare the ground for Pole Beans exactly the same as for Bush Beans. The poles should be set up firmly, three feet apart, and five beans planted around each pole one inch deep, in a circle. Do not heap the earth around the pole, keep it flat. It is believed best to plant Limas with the eye down. They then come up quicker. They mature a week or two later than bush beans.

Kentucky Wonder (Old Homestead). Early, long round green pods, best producer of LAZYWIFE, Is stringless when very young, white, medium late, excellent yield. Pkt. 5c; 1/4 Ib. $10 \mathrm{c} ; 1 / 2$ Ib. $15 \mathrm{c} ; \mathrm{Ib} .30 \mathrm{c} ; 2$ Ibs. $55 \mathrm{c}$

KENTUCKY WONDER WAX. Similar to Golden Cluster Wax. Long yellow pods, flat, broad Pkt. 5c;1/4 Ib. 10c; $1 / 2$ Ib. $15 \mathrm{c} ;$ Ib. 30c; 2 Ibs. 55c.

EARLY JERSEY LIMA. Good early pole lima, fine variety. Pkt. 5c; 1/4 Ib. 10c; 1/2 Ib. 15c; Ib. 30c. TALL HORTICULTURAL, or SPECKLED CRANBERRY. Old standby. Pkt. 5c; 1/4 ib. 10c; $1 / 2$ Ib. $15 c$; Ib. 25 c.

SCARLET RUNNER. A quick climber, red flowers in abundance. Pkt. 5c; 1/4 Ib. 15c; 1/2 Ib. 25c; Ib. $45 \mathrm{c}$.

For Field Beans, see page 41 .

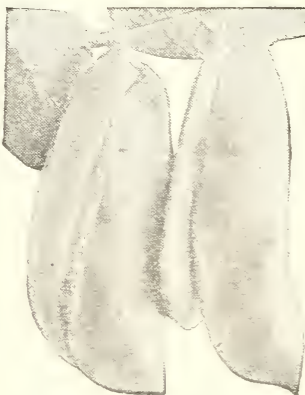

Burpee's Bush Lima 


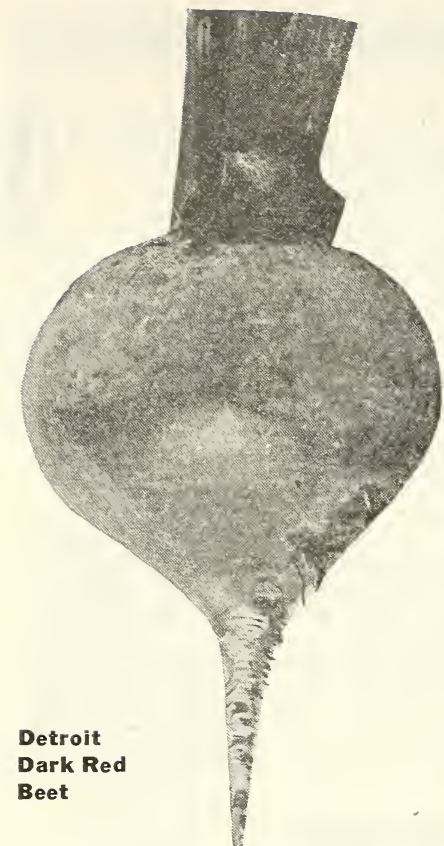

\section{BRUSSELS SPROUTS}

One ounce will sow a bed $40 \mathrm{sq}$. ft. and produce about 2,000 plants. HALF-DWARF, or PARIS MARKET. Hardy "Miniature Cabbages." Pkt. 5c; oz. 20 c; $1 / 4$ Ib. 60 c; Ib. $\$ 1.75$.

\section{CABBAGE}

Three ounces seed to 100 yards of row. One ounce will produce 2,000 plants. The best way to raise Cabbage in the small garden is from the plants. Cabbage requires an abundance of both moisture and tilling. It is also advisable to enrich the ground if possible. Fertilizer may be conserved by placing a small amount under each hill early Cabbage 18 inches apart in rows and two feet apart between rows. Late Cabbage tho feet apart in rows and three feet apart between rows. Cultural leaflet on request: two feet apart in rows and three feet apart between rows. Cult

If Cabbage seed is treated with SEMESAN it will help lessen the root rot. EARLY JERSEY WAKEFIELD.

variety. American seed. Pkt. $\mathbf{5 c}$

Oz. $25 \mathrm{c} ; 1 / 4$ lb. $75 \mathrm{c}$

EARLY VINNIGSTADT. Excellent early variety. Pkt. 5c

OZ $25 \mathrm{c}: 1 / 4 \mathrm{D}, 75 \mathrm{c}$

FARLY DWARF FLAT DUTCH. Round heads, standard sort. Pkt. 5c; oz. 25c; $1 / 4$ lb. $75 \mathrm{c}$.

ALL SEASONS. Medium, second early, semi-flat heads. Pkt 5c; oz. 25c; $1 / 4$ Ib. 75 c.

GOLDEN ACRE. The earliest of the Danish varieties, being 10 days ahead of Copenhagen Market. The heads are medium Valuable for early market. Pkt. 10c; oz 50c; $1 / 4$ Ib. $\$ 1.50$.

Copenhagen Market. "D e p enda ble SEDS European Market. The earliest large, roundSE $:$ DS $:$ headed cabbage offered today. It is nearly as Bf early as Early Jersey Wakefield, heads perfectly round and very solid. It is very compact in habit and can be planted as close as Wakefield. The heads all mature and can be planted as close as Wakefield. The heads all mature at one time and will stand longer than the Wakefield
bursting. Danish seed. Pkt. 5c; oz. 40c; 1/4 $\mathbf{~ b . ~ \$ 1 . 2 5 . ~}$

\section{Danish Round Head (Short-Stem Hollander).} strain, keeps splendidly. Our Danish seed is direct from the grower. None better. Pkt. 5c; oz. 30c; $1 / 4$ lb. 90c.

GLORY OF ENKHUIZEN. Medium, solid head, good cropper. Pkt. 5c; 0z. 30c; $1 / 4$ lb. 90c.

PREMIUM LATE FLAT DUTCH. For kraut, good standard sort. Plkt. 5c; 0z. 25c; $1 / 4$ Ib. 75 c.

DRUMHEAD SAVOY. Curled leaf, excellent quality. Pkt. $5 \mathrm{c} ; 1 / 2$ oz. $15 \mathrm{c} ; 0 \mathrm{z}, 25 \mathrm{c} ; 1 / 4 \mathrm{Ib}, 75 \mathrm{c}$

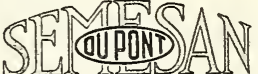
Makes Seeds Healthy

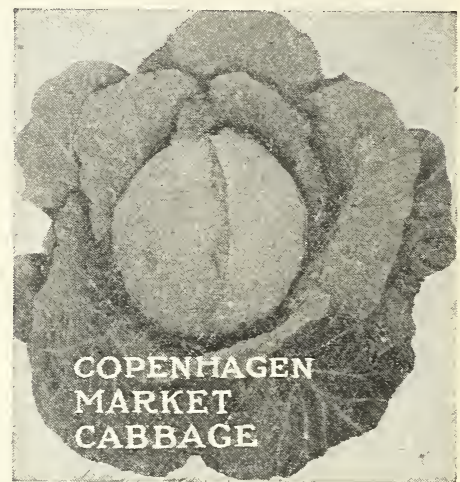

CABBAGE PLANTS, EARLY Ready in April. Per doz. 25c; per 100 75c; postpaid.

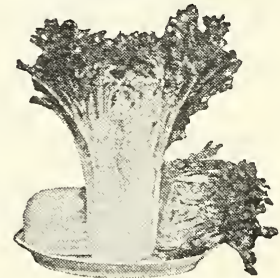

Pe-Tsai
CHINESE CABBAGE OR CELERY CABBAGE

PE-TSAI is a distinct vegetable from our common cabbage. It grows upright, leaves are tied together to bleach. Resembles Romaine or Cos Lettuce. This vegetable is very popular in California. It does well in Colorado. Pkt. 5c; $1 / 2$ oz. $20 \mathrm{c} ;$ oz. 35c; $1 / 4$ ib. $\$ 1.00$.

When troubled with bugs, worms or lice on cabbage and cucumbers, dust the plants with "Slug-Shot." 1-lb. can 25c. By mail 35c.

\section{HOTKAP PROTECTORS}

Will save your early plants from frost. 12 for $30 \mathrm{c}$; by mail, 35 ; 100 for $\$ 1.50$; by mail $\$ 1.65$. For larger quantity, see page 49.

\section{Eat CARROTS for Health}

Two ounces for 100 feet drill.

Furrows for Carrots should be fourteen inches apart and from a half-inch to an inch deep. The seed can be sown from mid-April to mid-May; it should be sown rather close, as Carrots do not germinate very well. Thin the plants out to four inches apart when they are four inches high. Soil for Carrots should be particularly well tilled before they are planted.

OXHEART (Guerande). Very early, orange, crisp and tender. Pkt. 5c; oz. 10c; 1/4 Ib. 35c.

Chantenay (Model). Golden-orange color; attractive. Danvers Medium size, heavy yielder and very fine sort. Pkt. Pkt. 5c; oz. 10c; $1 / 4$ Ib. 35c. 


\section{CAULIFLOWER}

One ounce will sow a bed $40 \mathrm{sq}$. ft. and produce about 2,000 plants.

All our Danish seed is growers' first quality sifted seed, thus higher cost For the small garden we advise getting Cauliflower flants in preference to growing from seed. The cultivation is the sane as that of Cabbage, excert affect this very much. Tie the long leaves together over the growing liead to keep it white.

\section{Early Danish Perfection Snowball.} inches being far enough apart. Pkt. 15c; $1 / 4$ oz. $75 \mathrm{c} ; \mathbf{0 z} . \$ 2.25$;

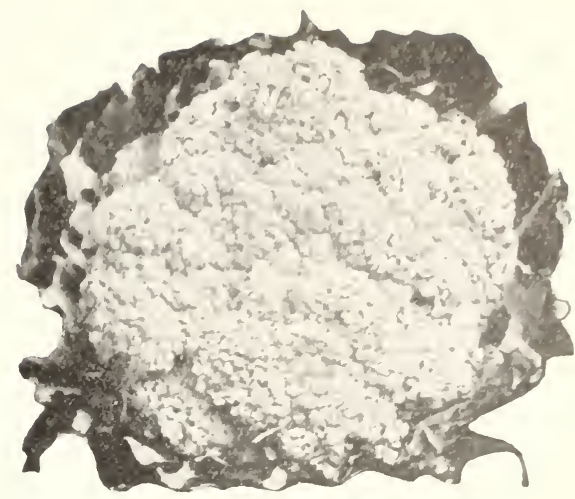

Early Danish Perfection Snowball

(ants from frost. 12 for $30 \mathrm{c}$; by mail 35c. 100 for 1.50 ; by mail $\$ 1.65$. For larger quantity, see page 49.

\section{CELERY Crisp and Tender}

Three ounces of seed to 100 yards of row. One ounce will produce 7,000 to 10,000 good plants. Celery, to be raised from the seed, requires almost expert care. It is better for those who are not practical gardeners to buy Celery October. Celery is by nature a marsh plant, and the soil about it must be kept wet, especially when the plants are young. When they get to be about four inches high, shear off the tops; it makes the plant more stocky. As the plants grow, gradually draw the earth up around them to keep the stalks white; by the end of fall all should be covered but the tops. A heavy paper wrapped around each stalk will insure tender, white plants. Keep the ground well loosened and cultivated; this is imperative on account of the moisture required by the plants. Celery is planted in rows that should be at least three feet apart. About 30,000 plants to the acre. Cultural leaflet on. request. Celery. For home and also for market.

SEMESAN will help to increase your celery crop.

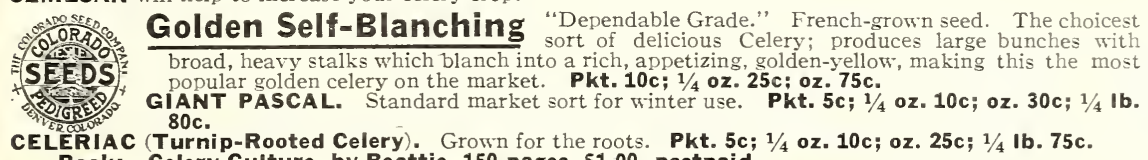

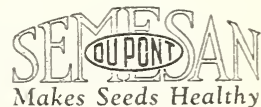

Book: Celery Culture, by Beattie, 150 pages, 51.00 , postpaid.

\section{CELERY PLANTS}

Early varieties ready May 20th. Doz. 25c; 100 75c; all postpaid. Late Celery plants quoted in June.

\section{CHICORY}

LARGE-LEAYED. For salads. Pkt. 5c; oz. 20c; $1 / 4$ Ib. 60c; Ib. $\$ 1.75$

WITLOOF (Brussels). True French Endive and very best variety. Pkt. 5 c; oz. 25 c; $1 / 4$ Ib. 70c; Ib. $\$ 2.00$.

\section{CHIVES}

A member of the Onion family. Hardy. The growing plants are in bunches that can be divid
bunch 25c each, postpaid.
COLLARDS

GEORGIA, or SOUTHERN. The standard variety for greens. $\mathbf{1} / \mathbf{\text { Ib. }} 60 \mathrm{c}$.

\section{CORN, SWEET}

One pound will plant 100 hills. 10 pounds an acre.
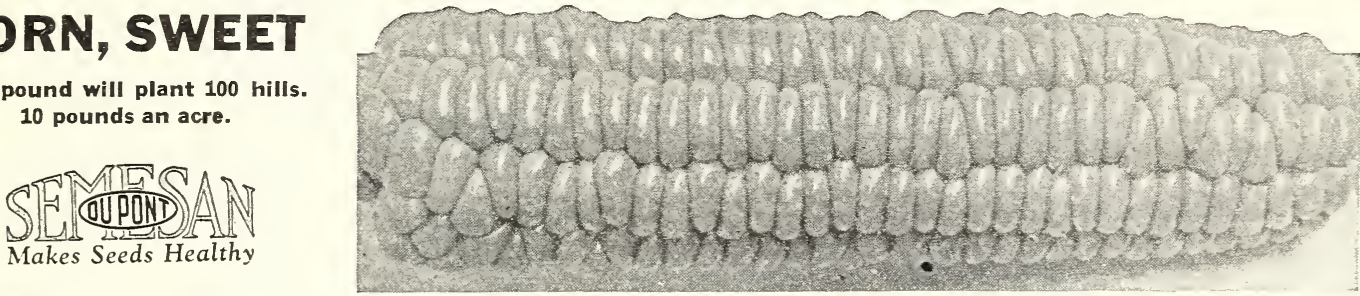

SEMESAN TREATMENT on your Sweet Corn Seed will increase germination.

Golden Bantam Sweet Corn

Corn should be planted to the north of the garden, so as not to shade the other crops. It should not be planted in a very small garden unless it is the only crop to be raised. It needs shallow but continual tilling. Just after the middle of MIay is a good time to plant. The rows should be three feet apart, the kernels sown three to etter every six inches in the furrow: When the Corn is well started, pull out all but one stalk to each place. Keep the little shoots or suckers cut from around the roots. The ears are ready to pick when the silk is brown and the kernels on the tip are plump. Do not molest the ears of growing corn; it is liable to spoil them.

Prices for all varieties, unless otherwise mentioned; Pkt. 5c; 1/4 Ib. 10c; 1/2 Ib. 15c; Ib. 25c; 2-Ib. pkg. 45c.

Lears on a stalk, growing only 4 to 5 feet high.

ARLY EVERGREEN. Similar to Stowell's, though medium early, good quality.

ARLY MINNESOTA. Early standard variety of medium size ears.

OUNTRY GENTLEMAN. Shoe-peg kernels. Medium large, early canning variety. $45 \mathrm{c} ; 2$ Ib. pkg. $80 \mathrm{c}$.

2 lb. pKg'S EVER

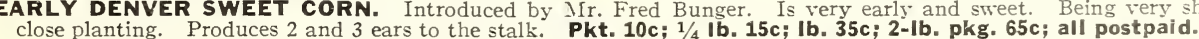

\section{CORN, POP}

Three to four pounds will plant an acre.

WHITE RICE. Sharp kernels, standard variety. Pkt. 5c; 1/4 Ib. 10c; Ib. 20c; 2 Ibs. 35 c.

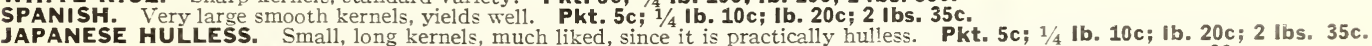

JAPANESE HULLESS. Small, long kernels, much liked, since it is practically hulless. Pkt. $5 \mathrm{c} ; 1 / 4 \mathrm{Ib}$. 10 10 ; Ib. 20 c;
We pay postage on all seeds and plants priced on this page. For quantity prices, see page 39 . 


\section{CRESS}

Curled. Pepper Grass for garnishing with Parsley. Pkt. 5c; oz. 10c; 1/4 Ib. 25c; Ib. 75c. Water Cress. Grows in running water. Pkt. $10 \mathrm{c} ; 1 / 4$ oz. 20c; oz. $50 \mathrm{c} ; 1 / 4 \mathrm{Ib}$. $\$ 1.50$.

\section{CUCUMBERS}

One ounce will plant $\mathbf{5 0}$ hills. Two pounds will plant an acre.

Dig holes at least five feet apart. They should be a foot wide and five inches deep. Fill each hole to within an inch of the top with equal parts of sand and well-rotted stable manure thoroughly mixed. Scatter at least ten seeds in it, well apart, and cover them with half an inch of fine soil, pressing it down. From the middle to the last of May is planting time. Thin out to three plants to a hill. Our seed is all Colorado-grown. Cultural leaflet on request. Cucumbers. Special culture or growing under glass. Lse

Use SEMESAN POWDER on your Cucumber Seed to increase germination and prevent leaf

"HOTKAPS" are excellent protectors from late frosts. Have them ready for your cucumbers. \% result of years of selection. Averages 8 ${ }_{t}$ to 10 inches lon, pe, it is very popular. It is similar to Woodruff' Hybrid. We heartily recommend it. Pkt. 5c; oz.

DELTUS. Burrell's stock. (Similar to Barteldes Cucumber.) Very dark green. Exceptionally uniform in shape and color, averaging 8 to 12 inches long. One of the very popular varieties for slicing, in fact the best for high class market. Forces well. Pkt. 5c; oz. 25c; 1/4 Ib. 75c. HENDERSON'S WHITE SPINE. Crisp, tender, rather light color. Pkt. 5c; 0z. 15c; 1/4 Ib. $40 \mathrm{c}$ IMPROVED LONG GREEN. The standard green, very prolific. Pkt. 5c; oz. 15c; 1/4 Ib. $40 \mathrm{c}$. SNOW'S PERFECTION PICKLE. Smaller than Chicago Pickle and more productive. Actually the best small pickle cucumber on the market. Pkt. 5c; oz. 15c; 1/4 Ib. 35c.

IAPANESE CLIMBING. Climbs; useful and ornamental. Pkt. $5 \mathrm{c} ;$ oz. 15c; 1/4 Ib. $50 \mathrm{c}$

WEST INDIA GHERKIN (bur). For pickles. Pkt. $5 \mathrm{c} ; 0 \mathrm{z} .15 \mathrm{c} ; 1 / \mathrm{lb} .50 \mathrm{c}$.

LEMON CUCUMBER. Late, small, oval. Pkt. 5c; oz. 15c; $1 / 4$ Ib. $50 \mathrm{c}$.

ENGLISH FRAME (Telegraph). The variety famous in European and American big cities, growing in greenhouses to a length of 15 to 20 inches long. Pkt. of 10 seeds 25 c; 100 seeds $\$ 1.50$.

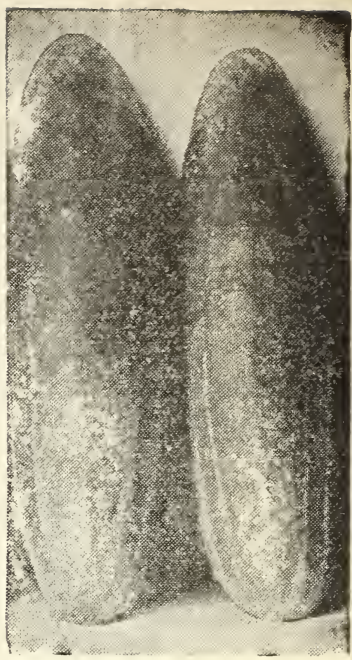

Clark's Special Deep Green

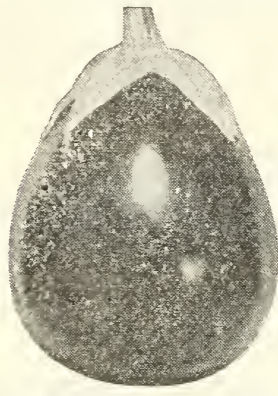

Improved Large Purple Spineless Eggplant

\section{EGGPLANT}

One ounce will produce 1,000 plants.

Sow in hotbeds very early in the spring; thin them out as soon as big enough to be handled to 3 or 4 inches each wav, and transplant to 2 or 3 feet apart in very rich. warm ground. Do not plant them outside till nights are real warm. Hoe often and hill-up gradually till they blossom.

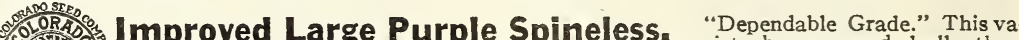 riety has superseded all others SEEDS both for market and home garden; it is by far the best variety, the fruits of largest . size and perfect form, eight or ten grow on a plant. Our stock is extra selected from} the best grower in New Jersey. Pkt. 10c; $1 / 4$ 0z. 20c; 0z. 50c; $1 / 4 \mathrm{lb}$. $\$ 1.50$.

BLACK BEAUTY. Very dark color, a few days earlier than Large Purple, longer in shape. Pkt. $10 \mathrm{c} ; 1 / 4$ 0z. $20 \mathrm{c}$; oz. $45 \mathrm{c} ; 1 / 4 \mathrm{lb}$. $\$ 1.35$.

\section{EGGPLANTS, TRANSPLANTED}

Ready in late May. Dozen 40c; $100 \$ 1.50$; postpaid.

\section{ENDIVE}

Culture similar to Lettuce. Used in salads and garnishing. One ounce will sow 20 square feet.

GREEN CURLED. Blanches splendidly. Pkt. 5c; oz. 15c; 1/4 lb. $40 ;$ Ib. $\$ 1.15$.

WHITE CURLED. Pale green leaves. Pkt. 5c; oz. 15c; 1/4 Ib. 40c; Ib. \$1.15.

Broadleaved-Batavian (Escarolle). Largest and most 40c; Ib. \$1.25.

For French Endive, see Chicory, page 31.

\section{GARLPC}

Propagated by division of sets. Price fluctuates. $1 / 4 \mathbf{~} \mathbf{b} . \mathbf{1 5 c}$; $\mathbf{~ b . ~} \mathbf{3 5 c}$; 2 lbs. 65c; postpaid.

\section{HERBS}

CARAWAY. Seeds used in bread, confectionery, etc. Pkt. 5c; oz. 10c; $1 / 4$ Ib. $25 \mathrm{c}$

Pkt. 5c; oz. 10c; $1 / 4$ CORIAN

DILL. Leaves and seeds used in pickles, preserves. Pkt. 5c; oz. 10c; $1 / 4$ Ib. $25 \mathrm{c} ; \mathrm{ib} .75 \mathrm{c}$.

LAVENDER. A popular perfume, true English-grown. Pkt.10c; oz. 50c. MARJORAM, SWEET. For seasoning. Pkt. 10c; 0z. 35c; $1 / 4 \mathrm{Ib} . \$ 1.00$. SUMMER SAVORY. For seasoning. Pkt. 10c; oz. 30c; 1/4 lb. $90 \mathrm{c}$. SAGE. Broad-leaved. English seed. For seasoning. Pkt. 10c; oz. $40 \mathrm{c} ; 1 / 4$ Ib. $\$ 1.25$; Ib. $\$ 3.50$.

SAGE ROOTS. Good 1-year clumps. Each 30c; postpaid.

TARRAGON. The leaves are excellent to flavor vinegar. Roots, per Clump $36 \mathrm{c}$, postpaid.

THYME. For seasoning in soups, etc. Pkt. 10c; oz. 50c; 1/4 Ib. $\$ 1.50$.

The following Herbs we can supply in 10c pkts. Catnip, Rosemary, Wormwood

\section{HORSE-RADISH ROOTS}

This is cultivated from roots, and is almost sure to grow and increase rapidly. 12 suitable roots for planting 25c; $100 \$ 1.00$; all postpaid.

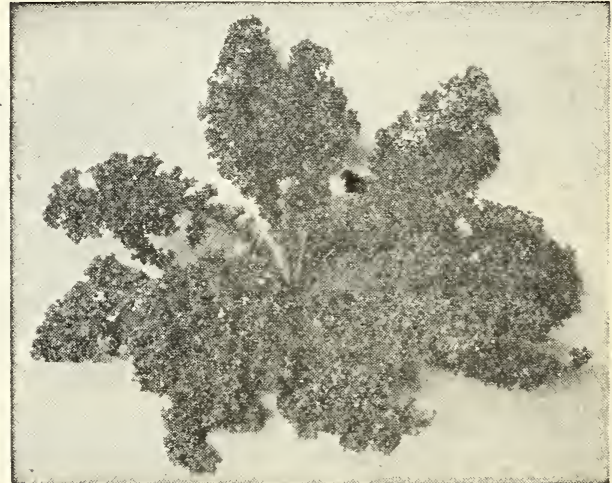

Dwarf Green Kale

\section{KALE OR BORECOLE}

One ounce will produce 2,000 plants.

Dwarf Green. Curled leaf, best fiavor. Pkt. $\mathbf{5 c}$

TALL GREEN CURLED (Scotch', 2 to 3 feet. Pkt 5c; oz. $15 \mathrm{c} ; 1 / 4$ Ib. 40 c; Ib. $\$ 1.25$

\section{KOHL-RBA}

TURNIP-ROOTED CABBAGE

Treat and cultivate like Early Cabbage.

EARLY WHITE VIENNA. Light green, short, narrow leaves. Pkt. 5c; oz. 20c; 1/4 Ib. 60c; Ib. $\$ 1.75$.

\section{LEEK}

LARGE AMERICAN FLAG. Early. Pkt. 5c; oz. 20c; $1 / 4$ Ib. $60 \mathrm{c} ; \mathrm{Ib} . \$ 1.75$. 
One ounce for 200 feet of row. One ounce of Head Variety will plant 400 feet of row.

Lettuce will stand slight frosts, and is therefore one of the first things to plant; if the ground is well prepared, early $A$ pril is not too soon. It can be planted up to the middle of July: and many prefer the later plantings. Hlace seed in trench and many prefer the later plantings. Pace seed in trench half an inch deep, cover whe plants should be up in about a week. press the soil down. The plants should be up in about a week. If head varieties are wanted, thin out to four or five inches. then be cut or they will rapidly go to seed, especially in hot weather. The rows of lettuce should be at least a foot apart. The quality of the lettuce depends on the tilling-keep the hoe busy. A special cultural leaflet on Lettuce Growing in Colorado free upon request.

\section{*These varieties form heads.} \% ᄀSEEDS 2 Dark Iceberg, or Select New, York Wonderlettuce we believe to be the finest in cultivation. lettuce we belis run to seed, mammoth heads, like small cabbages, bright run to seed, mammoth heads, like small cabbages, bright green. Our seed is direct from certified stock grown in
California by Rohnert and by Morse. Pkt. 5c; oz. 25c

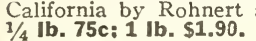

* MAY KING. Select strain, early, very hardy, and popular.

Pkt. 5c; oz. 15c; 1/4 Ib. 40c.

*Improved Eig Boston Large, firm heads, fine oz. $15 \mathrm{c} ; 1 / 4$ Ib. $40 \mathrm{c}$.

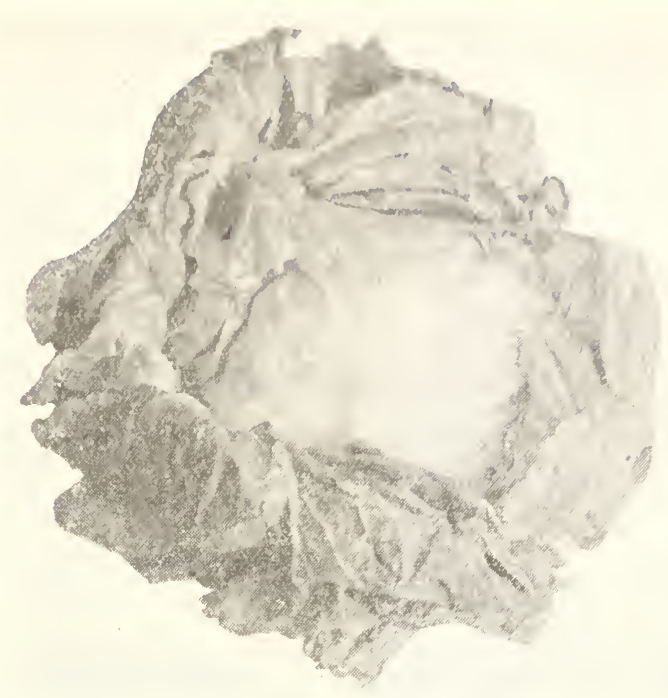

Los Angeles Market or New York Wonderful Lettuce

Grand Rapids Forces well, crisp and tender. Pkt. 5c; oz. 15c; 1/4 lb. Grand Rapids 40c.

*DENVER MARKET. Wrinkled loose semi-heads, fine variety. Pkt. 5c; oz. 15c;

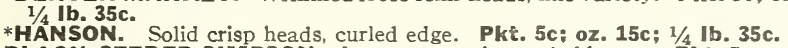

BLACK-SEEDED SIMPSON. Large, attractive curled leaves. Pkt. 5c; oz. 15乞; $1 / 4$ Ib. 35 c.

SIMPSON'S EARLY CURLED. Loose leaves, good variety. Pkt. 5c; 0z. 15c;
$1 / 4$ Ib. 35c. $1 / 4$ Ib. $35 c$.

*PRIZE HEAD. Brown edge leaves, early, attractive sort. Pkt. 5c; oz. 15c;

$1 / 4$ Ib. 35c.
ROMAINE (Paris White Cos). U'pright, very tender and now very popular on market. Pkt. 5c; oz. 15c; $1 / 4$ lb. 40 c.
materight

\section{Mushroom Spawn}

LAMBERT'S DIRECT PURE CULTURE SPAWN. Produced from tissue cultures invigorated by frequent reference to sport stock. Bricks weigh one pound and will spawn eight square feet of beds.

Cultural Leaflet frae upon request.

Per brick 35c; 5 bricks $\$ 1.50$; postpaid. If by express or freight, not prepaid, 10 bricks If by express or freight, not prepaid, 10
$\$ 2.25 ; 25$ bricks $\$ 4.75 ; 100$ bricks $\$ 18.00$.

\section{MUSKMELON OR CANTALOUPE}

One ounce for 50 hills, 3 pounds per acre.

Muskmelon planting and cultivation throughout are the same as those used in raising Cucumbers. Is considered rather delicate for northern latitudes, but with care can be successfully grown. Starting the plants in pots or small strawberry boxes indoors and then setting out after frost is over gives early production. The pleasure of raising them is worth the effort.

Our Melon Seeds are all taken from carefully selected specimens.

HALE'S BEST ROCKY FORD CANTALOUPE. This strain is now acknowledged by the leading Rocky Ford growers to be the most profitable. Its earliness puts it ahead, and its firm flesh makes it an excellent shipper. Salmon color, slightly oblong. deeply netted. Pkt. $5 \mathrm{c}$; oz. $15 \mathrm{c} ; 1 / 4 \mathrm{Ib} .50 \mathrm{c}$.

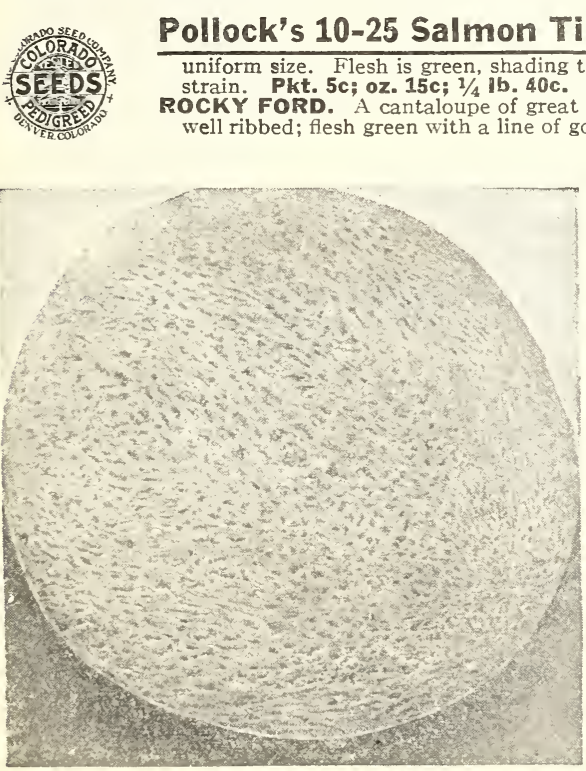

Pollock's 10-25 Salmon Tint uniform size. Flesh is green, shading strain. Pkt. 5c; oz. $15 \mathrm{c} ; 1 / 4$ lb. $40 \mathrm{c}$

"Dependable Grade." This is considered the most satisfactory of the Rocky Ford types of Cantaloupe. It produces heavily netted fruits of
on tint. Very strong rust-resister. Cantaloupe growers may rely on this

CKY FORD. A cantaloupe of great celebrity, grown at Rocky Ford. Small in size but of very superior flavor; rind well ribbed; flesh green with a line of gold just beneath the skin. Pks. 5c; oz. 15c; 1/4 Jb. 35c.

Greeley Wonder Muskmelon (Golden Queen). Is a very thick meat. They grow 4 to 6 pounds, 6 to 9 inches diameter, and very prolific. Shape is slightly flat, partly netted, very deeply ribbed. Very popular in Denver market. Many prefer it to Rocky Fords. Don't fail to plant Greeley Wonder. Pkt. 5c; oz. 15c; 1/4 ib. $49 \mathrm{c}$.

SURRELL'S GEM (Defender). Pink, fine grained. Pkt. 5c; oz. 15c; $1 / 4$ Ib. $40 \mathrm{c}$.

EMERALO GEM. Green, rather small, early, sweet. Pks. 5c; oz. 10c; $1 / 4$ Ib. $25 c$.

HACKENSACK. A good trpe of the old Eastern Muskmelon. Large, green, very sweet, deeply ribbed. Pikt. 5c; oz. 10c; 1/4 Ib. 30c.

ACME (Baltimore). Green, firm fiesh. Pkt. 5c; oz. 10c; 1/4 Ib. 25c.

PAUL Rose (Petosky). Green shin, fruit oval. Pkt. 5c; oz. 10c; 1/4 Ib. 25c.

Honey Ball Cantaloupe. Looks like Honey Dew, though meat with greenish-white smoth skin. Keeps two to three weeks, Splenmeat with greenish-white smooth skin. Keeps
did shipper. Pkt. 5c; oz. 20c; $1 / 4$ !b. 50c.

HONEY DEW CASABA. Originated at Rocky Ford. This is decidedly the sweetest and most juicy of any melon grown. White flesh and light cream color skin, a long keeper, in fact ripens after being removed from the vine. Pkt. 5c; oz. 15c;1/4 Ib. $40 \mathrm{c}$.

IMPROVED HYBRID. Deeply ribbed, yellow with green mottled skin suitable only where season is long. Pkt. $5 \mathrm{c} ; \mathbf{0 z} .20 \mathrm{c} ; 1 / 4 \mathbf{I b} .69 \mathrm{c}$.

Book: Melon Culture, 100 pages, $\$ 1.00$, postpaid.

HOTKAP PROTECTORS will protect vour melon plants from late frosts.

12 for $30 \mathrm{c}$; by mail $35 \mathrm{c}$. 100 for $\$ 1.5$; by mail $\$ 1.65$. See page 49 for larger quantity.

We pay postage on all seeds and roots priced on this page. For quantity prices, see page 39. 


\section{WATERMELONS}

One ounce for 20 hills. 3 to 4 pounds per acre.

Watermelon culture is the same as that of the Cucumber, but the hills should be eight to ten feet apart.

Kleckley's Sweet. Often called Rocky Ford. the sweetest of the et. large watermelons. Its fine quality makes it a most desirable variety for home use and nearby markets. Fruits are of large size, oblong in form, skin dark green, rind very thin; flesh bright scarlet with broad, solid heart, crisp and sugary. Pkt. 5c; oz. 10c; 1/4 Ib. 30c.

TOM WATSON. Long, sweet, one of the best shipping melons. Pkt. 5c; oz. 10c; $1 / 4 \mathrm{Ib}$. 30c.

IRISH GRAY. Is distinct from other oblong varieties. Is yellowish-gray. smooth surface and very hard skin. Flesh is bright red, and free from hard center. White-seeded. A good producer and aiso a good shipper. Pkt. 5\&; oz. $10 \mathrm{c} ; 1 / 4 \mathrm{Ib}$. 30c.

ANGELINO. A large round melon. Dark green skin. with a tinge of gold when ripe. Has bright red flesh. A truly long-distance shipper. White seed. Pkt. 5c; oz. 10c; $1 / 4$ lb. 35c.

PHINNEY'S EARLY. For dry land, round, sweet and good. Pkt. 5c; oz. 10c; $1 / 4$ lb. $25 \mathrm{c}$.

When the striped bugs eat your young melon plants, sprinkle liberally with Mammond's Slug Shot. See Insecticides, page 43.

\section{Citron Melon}

CITRON. Red seeded, the true Citron. best for preserving. Pkt. 5c; OZ.

COLORADO PRESERVING.
Green seed; excellent stock food. Pkt. 5c; oz. 10c; $1 / 4$ lb. 25c: Ib. $60 \mathrm{c}$.

GARDEN LEMON. Similar to Vine Peach. Pkt. 5c; 0z. 15c.

\section{Mustard}

Used as greens and also in salads. Liked for sweet, pungent taste.

One ounce will sow 50 feet of Wrill.

Pkt 5 condon. Yellow seed. Pkt. 5c; oz. 10c; $1 / 4$ lb. 20c; lb. $50 \mathrm{c}$

SOUTHERN CHINESE GIANT CURLED. Very' tender. mild. Pkt. 5c; oz, 10c; $1 / 4$ lb. 25c; lb.
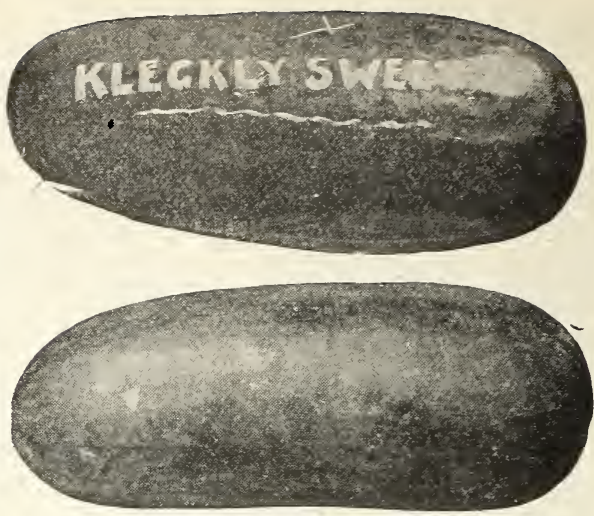

Tom Watson Watermelon

Treat Melon seeds with SEMESAN POWDER. It increases germination, and best of all it prevents wilt and black rot. Ask for booklet about SEMESAN.

\section{Okra or Gumbo}

One ounce for 30 -foot row.

Produces pods which are used to season and thicken soups.

WHITE VELVET (Creole). Long pods, considered the best. Pkt. $5 \mathrm{c} ;$ oz. $10 \mathrm{c} ; 1 / 4 \mathrm{lb}$. 20c; ib. $60 \mathrm{c}$

EARLY DWARF GREEN. Light green pods. earliest. Pkt. 5c oz. $10 \mathrm{c} ; 1 / 4 \mathrm{lb}$. $20 \mathrm{c}$; ib. $60 \mathrm{c}$.

Book, "GARDEN GUIDE." Amateur Gardeners' handbock, covers every step from spading the ground to preserving the harvest. $\$ 1.00$.

\section{ONIONS From Select Growers}

One ounce for 100-foot row, 4 to 5 lbs. per acre. Cultural leaflet free upon request: Onions. About soil, season and culture.

Sow the seed as soon as the frost is out of the ground. The rows should be two feet apart, the furrows half an inch deep. Sow the seed close, pressing the soil down firmly on them. Thin the plants out to three inches apart.

Use SEMESAN on your onion seed to prevent disease and increase the crop. Ask for circular.

\section{Colorado Grown Mountain Danvers}

\section{Globe. "Dependabie Grade." Y'ellow: Good keeper.

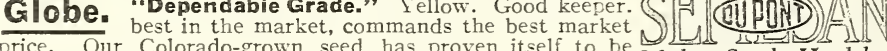 of special merit in producing very profitable marketable Makes Seeds Healthy \\ onions. Pkt. 5c; oz. 25c; $1 / 4$ lb. 75 c.}

TIGRE

DANVER'S YELLOW GLOBE. A standard yellow, good sort. Pkt. 5c; oz. 20c; 1/4 lb. 60c.

Colorado Red Globe. Our standard red; fine for market. Pkt. 5c; oz. 20c; 1/4 lb. 6cc.

LARGE RED WETHERSFIELD. Flat shape, much in demand. Pkt. 5c; oz. 15c; 1/4 lb. 45c. BROUYN AUSTRALIAN. Amber color, globe, medium size. Pkt. 5c; oz. 15c; 1/4 lb. 45c.

PRIZETAKER (Denia). Select pale yellow, globe, very large. Pkt. 5c; oz. 15c; 1/4 lb. 50c. Sweet Spanish. An American-grown strain of the famous Spanish variety, called Va:Is bronzy color skin, white inside, large oval shape. A big producer when started early. Does well in Colorado. Pkt. 5c; oz. 40 c; $1 / 4$ lb. $\$ 1.25$.

SILVER SKIN (White Portugal). Very mild. Pkt. 5c; oz. 25c; 1/4 lb. 70 c.

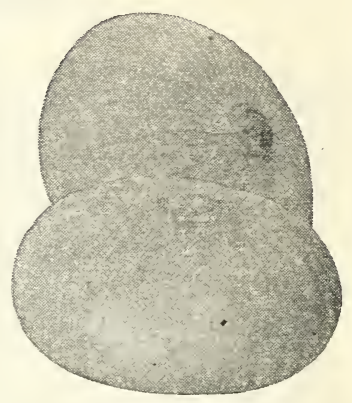

Danver's Globe

SEEDS, BULBS, ROOTS, TUBERS - ENTITLED TO SECOND CLASS EXPRESS RATES.

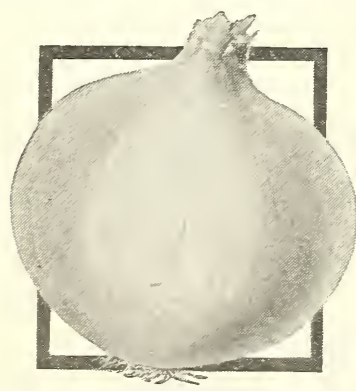

Sweet Spanish

SOUTHPORT White GLOBE. Mild flavor. Profitable sort. Pkt. 5c; oz. 25c; 1/4 lb. 70c. MAMMOTH SILVER KING. White, flat, popular at markets. Pkt. 5c; oz. 25c; 1/4 lb. 75c. EXTRA EARLY BARLETTA. French seed. Pkt. 5c; oz. 20c; 1/4 lb. 60c. BUNCHING ONION (White Lisbon). Imported. Oz. 15c; 1/4 Ib. 50c.

\section{ONION SETS}

Our Onion Sets are Colorado-grown, which are solid, and are far superior to eastern-grown sets. A pound equals about one quart. Prices all postpaid.

YELLOW BOTTOMS. $1 / 4$ lb. 10 c; $1 / 2$ lb. 15 c; lb. 25 c; 5 -lb lots, per lb. 20 c; $1 / 4$ bu. $\$ 1.25$. RED BOTTOMS. $1 / 4$ lb. 10c; $1 / 2$ lb. 15c; lb. 25c; 5-lb. lots, per lb. 20c; $1 / 4$ bu. $\$ 1.35$. WHITE BOTTOMS. $1 / 4$ lb. 10 c; $1 / 2$ lb. 15c; lb. 3Cc; 5 -lb. lots, per lb. 25c; $1 / 4$ bu. $\$ 1.50$.

Larger quantities quoted on application.

Book: New Onion Culture, illustrated, 140 pages, postpaid, $\$ 1.00$.

We pay postage on all seeds and sets priced on this page. For quantity prices, see page 39. BETTER SEEDS MAKE BETTER GARDENS 


\section{We specialize in the true \\ Bermuda Onion Plants - Order early! BERMUDA ONION PLANTS}

By using these young onion plants, you gain seveml weeks over the time forseed to produce young onions for the table, or make large onions. They are the true Bermuda Onion variety, which is mild and sweet.

They are started in Texas, are ready from February to in May. You should place your order in advance. March is when we have our main supply.

They are put up 100 in a bunch, 6,030 to a crate.

CRYSTAL WAX. IVhite Bermuda.

\section{YELLOW BERMUDA. Straw Color.}

Either: 100 plants $25 \mathrm{c}$; 1,000 plants $\$ 1.60$; postpald. 6,000 plants $(1 \mathrm{crate}) \$ 6.00$; prepaid.

Larger quantities quoted on application.

\section{PARSLEY}

One ounce to 100 feet of drill.

Parsley seeds are sown in a drill in the spring. The plants will die down in the fall and it protected with mulch will put out fresh foliage the next spring. Should be replanted cvery two

CHAMPION (Moss Curled). Very thickly curled and moss-like. We consider this the best variety for home or market garden. Pkt. 5c; oz. $\mathbf{1 0 c ;} \mathbf{1 / 4} \mathbf{I b}$. $\mathbf{3 0 c}$; Ib. $\mathbf{8 0 c}$.

TURNIP-ROOTED (Hamburg). For soups. Roots reseinble parsnip. Pkt. 5c; oz. 10c; 1/4 lb. $30 \mathrm{c}$; Ib. $80 \mathrm{c}$.

\section{PARSNIPS}

One ounce for 100 -foot row, 5 pounds per acre.

General culture for Parsnips is the same as for Beets, except a light or slightly sandy soil is best. May be left in ground through winter.

HOLLOW CROWN (Sugar Cup). This is the thick-shouldered type and is the best variety in cultivation; roots medium long, white, smooth, tender, sugary and of excellent flavor. Pkt. 5c; oz. $10 \mathrm{c} ; 1 / 4$ Ib. 30 c.

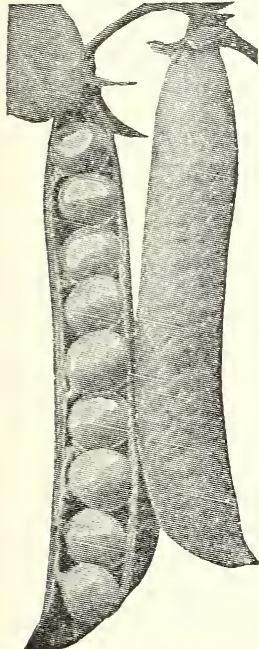

Dwarf Telephone Recommended for Western Planting

\section{GARDEN PEAS Sweet and Tender}

One pound will sow 50 feet, 90 pounds an acre.

The furrow for Peas should be four inches deep. Sow the seeds one inch apart and cover with one inch of fine soil, thus leaving part of the furrow unfilled above them. This is to be filled gradually with fine soil as the plants grow, until the furrow is filled level with the ground. By this method, the sun can warm through the soil to the roots. Peas can be planted as soon as the frost is out of the ground, the rows should be two a half feet apart. Plant the climbing varieties near a fence and train them on wire netting. Our seed all Western grown.

We pay all postage on Peas at these prices.

Alaska. Extra early and very hardy, smooth, good quality. Pkt. 5c; 1/4 Ib. 10c; 1/2 lb. 15c; lb. 25c; GRADUS. Good early. large, wrinkled seed. Pkt. 5c; 1/4 Ib. 10c; 1/2 Ib. 15c; Ib. 30c; 2 Ibs. $55 \mathrm{c}$. LITTLE MARVEL. Very dwarf, sweet, tender. Pkt. 5c; 1/4 Ib. 10c; $1 / 2 \mathrm{lb}, 20 \mathrm{c} ; \mathrm{lb} .35 \mathrm{c} ; 2 \mathrm{Ibs} .65 \mathrm{c}$

LAXTONIAN. Large peas, dwarf, productive, excellent quality. Pkt. 5c; $1 / 4 \mathrm{lb}, 10 \mathrm{c} ; 1 / 2 \mathrm{lb}$. 20c; Ib. 35c; 2 Ibs. 65 c.

Laxton's Progress. The earliest and by far the best of the large-podded. large-fruited wrinkled peas. Of all the varieties producing peas of equal quality this is the heaviest yielding. Pkt. $5 \mathrm{c} ; 1 / 4 \mathrm{lb} .15 \mathrm{c} ; 1 / 2 \mathrm{lb} .25 \mathrm{c} ; \mathrm{lb} .40 ; 2$ Ibs. $75 \mathrm{c}$.

AMERICAN YYONDER. Early dwarf, sweet and luscious. Pkt. 5c; 1/4 Ib. 10c; $1 / 2 \mathrm{lb}$. 15c; Ib. $3 \mathrm{Cc} ; 2 \mathrm{lbs}$. $55 \mathrm{c}$.

Dwarf Telephone (Daisy). The Mountain Telephone variety. Large pod, fine standard sort. Ib. 35c; 2 Ibs. 65c.

ALDERMAN (Improved Telephone), Very much like the Telephone: however, is earlier and produces more of large, well filled pods. Excellent for mountain gardens. Pkt. 5c; $1 / 4 \mathrm{Ib} .10 \mathrm{c} ; 1 / 2 \mathrm{Ib}$. 20c; Ib. 35c; 2 Ibs. 65 c.

TELEPHONE。 Tall, large, late, big pods and very prolific. Pkt, 5c; $1 / 4$ lb. 10c; lb, 30c; 2 lbs, $55 \mathrm{c}$. GRAY SUGAR. Edible brittle pods, good sort. Pkt, $5 \mathrm{c} ; 1 / 4 \mathrm{lb}, 15 \mathrm{c} ; 1 / 2 \mathrm{lb}$. 25c; Ib. $40 \mathrm{c}$.

For Field Peas, see page 41.

NITRAGIN INOCULATING BACTERIA FOR PEAS. Trial size $25 \mathrm{c} ; 1 / 4=$ acre size $40 \mathrm{C}$; $1 / 2$-acre size $60 \mathrm{C}$; acre size $\$ 1.00$; postpaid.

\section{PEPPERS}

One ounce will produce 1,500 plants.

Peppers, like Tomatoes, should be planted in a window garden about the first of March. They are grown and transplanted exactly like Tomatoes but the plants can be placed nearer one another in the ground say two feet a matoes but the plants can feet apart. A dozen good healthy Pepper Plants will supply the average family.

Ruby Giant. Of stocky growth, very vigorous, well branched and thickly Set with enormous fruit, much larger than the well-known Ruby King. The flesh is extremely mild and very thick. For salads it is unsurpassed sliced; of mild flavor. Pkt. $5 \mathrm{c} ; 1 / 4$ oz. $15 \mathrm{c}$; oz. $45 \mathrm{c}$.

RUBY KING. Large, excellent for mangoes, exceedingly productive. Pkt. 5c; $1 / 4$ oz. $15 \mathrm{c}$; oz. $45 \mathrm{c}$.

SWEET MANGO. Used when green. Pkt. $5 \mathrm{c} ; 1 / 4$ oz. 15c; oz. $45 \mathrm{c}$.

Chinese Giant. Extra large, thick flesh, red, mild. Pkt. 5c; 1/4 oz. 20c; oz.

LARGE LONG CHILI (Anaheim). Is the most popular as a commercial Chili, having a thick flesh, with a rreeable pungency, Pkt, 5c;1/4 oz, 15c;0z, 45c.

LONG RED CAYENNE. A small, long, bright red sort; very productive. Extremely trong and hot. Pkt. 5c; 1/4 oz. 15c; oz. $45 \mathrm{c}$.

For seed of Topepo or Tomato-Pepper, see page 38.

\section{PIMENTO PEPPER}

A new variety of Pepper that is not pungent. Especially desirable in canning, in pickles, etc. Is red and smooth like an apple. Thick skin. Easy to grow. Pkt. 5c; 1/4 oz. 15c; 0z. 45c. We pay postage on all seeds and plants priced on this page. For quantity prices, see page 39. 
One ounce for 20 hills; three pounds per acre.

The culture of Pumpkin is similar to Winter Squash.

Small Sugar (Pie). A small pumpkin, being about eight and fine grained flesh. Prolific and in every way desirable. The average weight is about five pounds. This is the variety the famous pumpkin pies are made of. There is nothing better than a good slice of juicy pumpkin pie. Pkt. 5c; oz. 10c; $1 / 4$ Ib. 30 c.

Large Cheese (Kentucky Field). Flat, yellow, orange skin. Pkt. $5 \mathrm{c} ; 0 \mathrm{z} .10 \mathrm{c} ; 1 / 4 \mathrm{lb} .25 \mathrm{c}$

KING OF MAMMOTHS (Potiron). Very large, forming immense pumpkins, salmon-colored. Pkt. 5c; oz. 10c; 1/4 Ib. 35c.

JAPANESE PIE. Crookneck, small one end. Pkt. $5 c$; oz. 15c; $1 / 4 \mathrm{Ib.} 45 \mathrm{c}$.

LARGE YELLOW FIELD. Common field variety. Pkt. 5c; Oz. $10 \mathrm{c} ; 1 / 4 \mathrm{Ib} .25 \mathrm{c}$.

When purchasing our seeds in $5 \mathrm{c}$ packets, make your order six or more of any one kind and get our special money-5aving price: "SIX 5c PACKETS FOR 25c."

\section{SEED POTATOES}

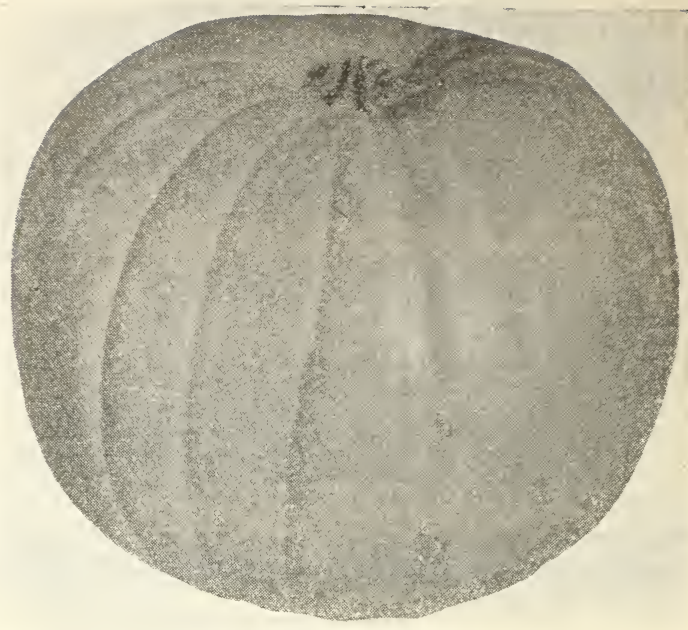

Large Cheese Pumpkin

PRICES DO NOT IN-

CLUDE POSTAGE

EARLY OHIO. The popular pink skin, oblong shape, early variety. Does well in home gardens.

RUSSET BURBANK. Medium late, general crop variety, oblong shape with netted skin. Excellent for baking.

PEACHBLOW (Red McClure). Is a profitable main crop variety. good producer and keeps well. Late.

Quantity lots of seed potatoes are shipped in 100-Ib. sacks.

have stock of some varieties from Wisconsin, we do recommen Colorado-grown Irish Cobbler, Triumph, Russet Burbank and

SEMESAN BEL does wonders in bettering the potato crop. Ask for literature.

PRICES: 3 lbs. 25c; 10 lbs. 60c; 25 lbs. $\$ 1.25$. If by mail, add 5c per pound. Larger quantities will be priced on application.

IRISH COBBLER. Nearly round, good size and clean white skin.

We believe it averages the earliest, and reasonably sure to make

crop. Is superseding the Early Ohio for home gardens.

EARLY TRIUMPH. A popular early variety where grown for

early market. The round red tubers are very attractive.

\section{RADISHES Crisp and Sparkling \\ One ounce for 100-foot row.}

Radishes can be planted very early - as soon as the ground can be worked and no danger of frost. The rows should be from eight inches to a foot apart, the furrows for the seeds about half an inch deep; and the seeds, when dropped into the furrow, about an inch apart. Press fine soil down over them to the depth of the furrow. As the plants grow, thin them out like beets. Radishes mature, depending on the kind, in from four to six weeks; the turnip-shaped ones are the earlier.

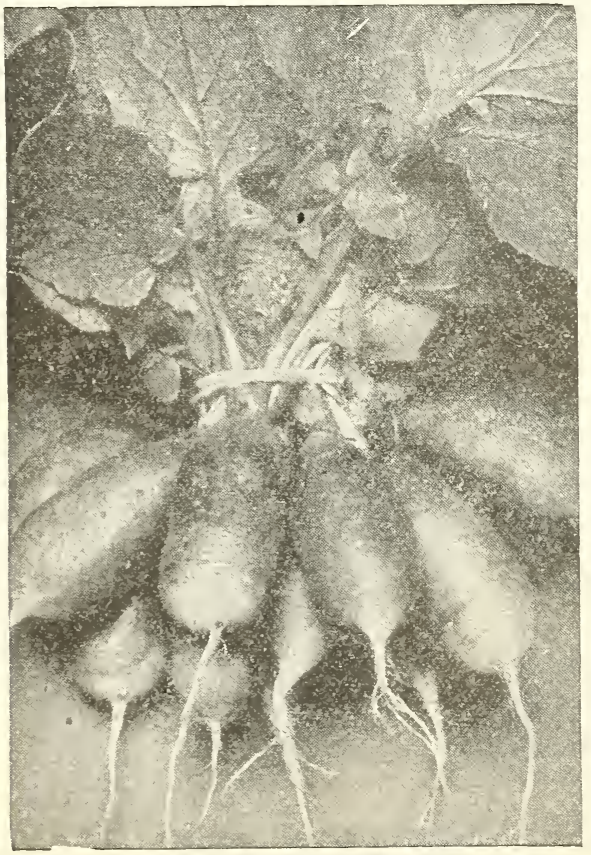

French Breakfast Radishes
Saxa. A very select strain of all red. exceedingly early, round and does well under glass. Pkt. 5c; oz. 10c; 1/4 Ib. 35c.

Vick's Early Scarlet Globe. One of the best for or forcing, under glass should plant liberally of this stock, averaging lb. $35 \mathrm{c}$.

Early Scarlet Turnip, White Tipped. Beauty, round, edible size in 35 days. Pkt. 5c; 0z. 10c; $1 / 4$ Ib. 30c.

EARLY SCARLET TURNIP. Round, red, of delicate flavor. Pkt. 5c; oz. $10 \mathrm{c} ; 1 / 4$ Ib. $30 \mathrm{c}$.

CRIMSON GIANT. Early, very large, oval, popular variety. Pkt. 5c; oz. $10 \mathrm{c} ; 1 / 4 \mathrm{Ib} .30 \mathrm{c}$.

French Breakrast. Extremely early. A medium-sized radish, very crisp and tender. Of a beautiful scarlet color except near the tip, which is pure white. Pkt. 5c; oz. 10c; $1 / 4$ Ib. 30c.

GLASS (Cincinnati Market). Long, red, forcing. Pkt. 5c; oz. 10c; $1 / 4 \mathrm{Ib} .30 \mathrm{c}$.

LONG SCARLET SHORT-TOP. Bright scarlet, crisp, tender. Pkt. 5c; oz. $10 \mathrm{c} ; 1 / 4$ Ib. $30 \mathrm{c}$.

Icicle. The finest white variety and the earliest of the long snowy-white corts yet produced. It has but few tops, making it very desirable for forcing. The roots continue brittle, mild and crisp, until full grown. They have a peculiar and delicious freshness not found in the other sorts. Very rapid-growing, tender, with a delicate, fine grain. Finest for market or family use. Pkt. $5 \mathbf{c} ; \mathbf{0 z} .10 \mathrm{c} ; 1 / \mathbf{l} \mathbf{l b} .35 \mathbf{c}$

WHITE VIENNA. Long, white, medium early. Pkt. $5 \mathbf{c} ; \mathbf{0 z} .10 \mathrm{c} ; 1 / 4 \mathbf{~ I b . ~}$ 25c. CHINA ROSE. For winter, keeps well, rose color. Pkt. 5c; oz. 10c; CELESTIAL (California Mammoth White). Good keeper. Pkt. 5c;

ROUND BLACK SPANISH. For winter use. Pkt. 5c; oz. 10c; 1/4 lb. $30 \mathrm{c}$.

LONG BLACK SPANISH. For winter use. Pkt. 5c; oz. 10c; 1/4 Ib. 36c. JAPANESE MAMMOTH (Sakurajima). Large white, good keeper,

new and popular. Pkt. $5 \mathrm{c} ; 0 \mathbf{0 z} 20 \mathrm{c} ; 1 / 4$ lb. $60 \mathrm{c}$. 
Rhubarb or Pieplant

Like Asparagus and Celcry, Rhubarb is best bought by nonprofessional gardeners in the form of roots. These are set out in the early spring, three fect apart in the furrow, and in rows three feet apart. Provided therc is no standing water, Rhubarb grows well on almost any kind of soil, under ordinary cultivation. Roots ready in spring and late fall Leaflet free upon request: Rhubarb. Method of forcing indoors.

VICTORIA. Large standard market variety, excellent quality. Pkt. $5 \mathrm{c} ;$ ox. $15 \mathrm{c} ; 1 / 4 \mathrm{Ib} .45 \mathrm{c} ; \mathrm{Ib} . \$ 1.35$.

\section{- RHUBARB ROOTS}

These roots save you at least two years' time over plant-

ing secd. FROM SEED. 3 for $25 \mathrm{c}$; doz. 75c; 100 for $\$ 5.00$; postpaid

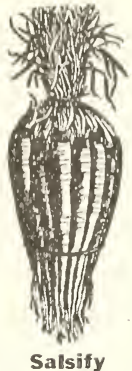

RUTABAGAS

One ounce to 150 -foot row.

ften known as Swedish T'urnivs. ('an to grown almost anywhere aud should be nucre extensively cultivated. Excellent table food and great stock food. Keo: (lll winter.

PURPLE TOP YELLOW (Bangholm), ()ur sreed is I) anish

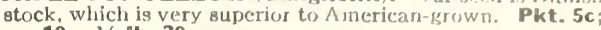
oz. 10c; $1 / 4$ Ib. $30 \mathrm{c}$.

\section{SALSIFY}

One ounce will sow 40 feet of drill.

Easily cultivated, stays in ground over winter. Slirsulrl be in every garden.

MAMMOTH SANDWICM ISLAND. Largest and best sort. Pkt. 5c; oz. 20c; 1/4 Ib. 60c; Ib. $\$ 1.75$.

\section{SPINACH}

One ounce for 50-foot row; 10 pounds per acre.

It is best to sow Spinach as early in the spring as possible without danger of hard frost, because if it is not cut before the hot weather it will toughen and spoil. It should be a fertile

King of Denmark Has extra large leaves, broad, Remains in sood conditiontly crimpled, dark green. Remains in good condition a lo

JULIANA. A very select strain of "Long Season' Spinach, Laroe, thick crimpled leaf, dark green, Pkt. $5 \mathrm{c}$; oz. $10 \mathrm{c}$ $1 / 4$ lb. 20c; Ib. 50c; 2 lbs. 90 c.

LONG STANDING. Large, smooth leaves of good size Pkt. 5c; 0z. 10c; 1/4 bb. 15c; Ib. 40c; 2 lbs. $75 \mathrm{c}$.

LARGE THICK-LEAVED VIROFLAY. Curly, thick leaves which grow to large size. Deep green. A rapid grower and the best variety. Pkt. 5c; oz. 10c; $1 / 4$ bb. 15c; Ib. 40c; 2 lbs. $75 \mathrm{c}$

BLOOMSDALE (Victoria.) Heavy foliage, dark green leaf. Savov variety. keeps well. Pkt, 5c;0z, 10c; 1/4 Ib, 15c; Ib. $40 \mathrm{c} ; 2$ Ibs. $75 \mathrm{c}$.

NEW ZEALAND. Extra large leaf, tall. Pkt. 5c; oz. 10c; $1 / 4$ ib. $20 \mathrm{c} ; 1 \mathrm{~b} .65 \mathrm{c}$

\section{SQUASH Good and good for you}

The Squash is first-cousin to the Cucumber, and should be planted and raised in the same manner. Squash, however, is usually planted later. The bush summer varieties of Squash can be planted five feet apart, but the running winter varieties should be eight to ten feet a part.

\section{SUMMER VARIETIES}

One ounce for 40 hills.

Yellow Summer Crookneck A favorite in both gardens, Fruit is long, of bright orange color. Rich and buttery. Very productive. Pkt. 5c; oz. 10c; $1 / 4$ ib. 35c. STRAIGHT NECK. Yellow. An improvement on the Crookneck, and larger. Pkt. $5 \mathrm{c} ;$ oz. $15 \mathrm{c} ; 1 / 4 \mathrm{lb} .45 \mathrm{c}$

White Bush Scalloped-Mammoth

(Patty-Pan). Early, clear white. Pkt. 5c; oz. 10c; 1/4
Ib. $35 \mathrm{c}$.

FORDHOOK. Bush, for late summer, yellow. Pkt. 5c oz. $15 \mathrm{c} ; 1 / 4$ Ib. $40 \mathrm{c}$.

LONG VEGETABLE MARROW (True English). Pkt. $5 \mathrm{c} ; 0 \mathrm{oz} .15 \mathrm{c} ; 1 / 4 \mathrm{lb} .40 \mathrm{c}$.
PROLIFIC MARROW. A standard fall variety. Pkt. $5 \mathrm{c} ; 0 \mathrm{z} .10 \mathrm{c} ; 1 / 4 \mathrm{lb} .25 \mathrm{c}$.

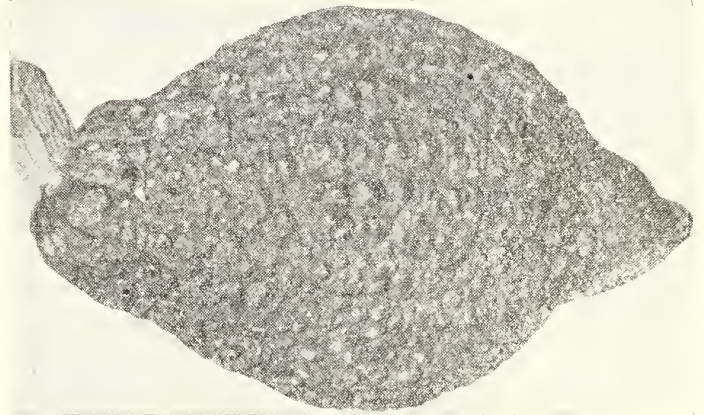

Marty Mubbard Squash

"Garden Guard" destroys squash bugs.

\section{WINTER VARIETIES One ounce for 20 hills; 4 pounds per acre.}

Hubbard (Warty). Our own strain of Hubbard Squash, is considered to be the finest of any grown. The fruit grown from are of our seed matures earlier, keeps better and commands a higher price than that grown from other seed. The vines are of strong, running growth and bear a good number of large warty specimens. The shell is hard, strong and dark green in color, thickly covered with rough, warty growth. The flesh is a bright orange-yellow, fine-grained, very dry, sweet and rich flavored. Pkt. $5 \mathrm{c} ; 0 \mathrm{z} .15 \mathrm{c} ; 1 / 4$ lb. $40 \mathrm{c}$.

GOLDEN HUBEARD. Similar to green Hubbard, though not so large, but very solid and early to ripen. Pkt. 5c; oz. 15c; 1/4 Ib. 4cc.

Acorn (Yama). Called Table Queen. Very small, with green skin, ribbed. Quality is equal to Hubbard. Just right to cut in half Acorn and bake. Matures in early fall and keeps well. Very novel appearance. Pkt. 5c; oz. 15c; 1/4 Ib. 45c.

BANANA. A grand new variety for late fall and winter use. Dark green, banana-shape, 20 to 25 inches long. Pkt. $5 \mathrm{c} ; \mathbf{o z} .15 \mathrm{c} ; 1 / 4$

Ib. 45c.
SIBLEY (Pike's Peak). Pear-shaped, late, good quality: Pkt. 5c; Oz. 15c; 1/4 lb. 40c.

DELICious. Thick orange-color flesh, for winter. Pkt. $5 \mathrm{c} ; 0 \mathrm{zz} .15 \mathrm{c} ; 1 / 4 \mathrm{lb}$. $40 \mathrm{c}$.

MAMMOTH CHILI. Orange color, very large. Pkt. $5 \mathrm{c} ; 0 \mathrm{oz} .15 \mathrm{c} ; 1 / 4 \mathrm{lb} .45 \mathrm{c}$.

TOBACCO

HAVANA. A standard variety. Pkt. 10c; oz. 50c.

\section{WONDERBERRY}

Q Q

flower, vegetable and fruit garden. $\$ \mathbf{2 . 0 0}$.
This product of Burbank's is truly a wonderful producer of small black berries on a small bush the size of a tomato plant. Used in jam, jellies, pies, etc. Grows quick from seed. Pkt. $10 \mathrm{c} ; 1 / 4$ oz. $50 \mathrm{c} ;$ oz. $\$ 1.50$. 


\section{TOMATOES Delicious}

One ounce will produce 1,500 plants; $1 / 4$ pound to transplant for one acre.

Tomatoes are planted indoors in a window garden about the first of March. When the third leaf of a plant has formed, put the plant into a three-inch pot or box. After all danger of frost is over the plants may be set in the ground. Do not plant Tomatoes within three feet of any other crop. Dig holes three feet apart and deep enough to allow placing the plant an inch or two deeper than it was in the pot. Cover the top of the pot with your fingers, holding the stem of the plant between them; then turn the pot upside down, tapping st with a trowel or other tool, when the plant will easily come out. Pl with a trowe dry, water it as soon as the plants are set. Some people. before transplanting Tomatoes, put a narrow ring of heavy paper loosely around the plant, just at the top of the soil, to keep off cutworms. June 1 st is the usual time for transplanting in northern latitudes. Tie the growing plants to stakes. We will have plants ready in May and June. Leaflets free upon request: Tomatoes. All about home culture and for market.

Tomato Seed should be carefully treated with SEMESAN POWDER to prevent wilt.

Marglobe. A new variety brought to popularity by seed disround. Slightly later than Earliana but larger. The bearing season is long, thus especially suitable for home garden. Much liked by canners. In New Jersey they claim nothing better in tomatoes. A truly wilt-resistant variety. Pkt. 5c; 0z. 50c; $1 / 4$ lb. $\$ 1.50$.

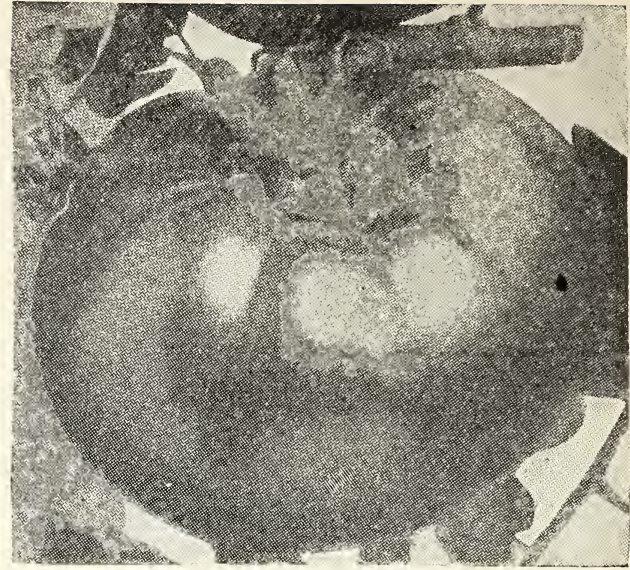

John Baer Tomato

THE BURBANK TOMATO. Burbank's own production, famed for uniform size, solidity and productiveness; a very beautiful red variety for either home or market garden. Pkt. 5c; oz. 50c; $\mathbf{1} / \mathbf{l b}$. $\$ \mathbf{1 . 5 0}$

variety for either home or market garden. Pkt. 5c; oz. 50 c; $1 / 4$ lb. $\$ 1.50$.
GLOBE. Select stock, for forcing; large. Pkt. 5c; oz. 40 c; $1 / 4 \mathbf{I b} . \$ 1.25$.

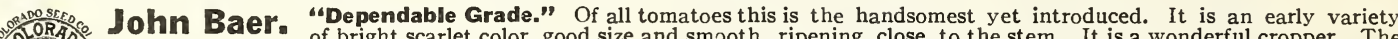
(t. If you want a tomato that will give entire satisfaction in every respect SEDS:- give this a trial. You will order more next year. Pkt. 5c; oz. 35c; 1/4 Ib. \$1.00.

\& BNY BEST. A beautiful bright red, smooth and uniform tomato. Especially suitable for greenhouse culture; also good outdoors. Pkt. 5c; 0z. 35c; $1 / 4$ lb. $\$ 1.00$.

CHALK'S EARLY JEWEL. Ball-shaped, smooth, bright red. Pkt. 5c; oz. 35c; 1/4 Ib. \$1.00.

EARLIANA. Selected strain, red, very early, bears freely. Pkt. 5c; oz, 35c; 1/4 lb. $\mathbf{\$ 1 . 0 0 .}$

BEAUTY. Delicate pink color, smooth. Very popular in Denver market, and especially in home gardens. Pkt. 5c; oz. 35c; 1/4 Ib.

$\$ 1.00$.

PONDEROSA, DWARF (Beefsteak). Purplish-red, large, popular. Pkt. 5c; oz. 50c; 1/4 Ib. \$1.50.

DWARF CHAMPION (Tree). Purplish-red. round, smooth. Pkt. 5c; oz. 50c; 1/4 Ib. \$1.50.

GOLDEN PONDEROSA. Large yellow, solid, smooth. Pkt. 5c; 0z. 50c; 1/4 Ib. \$1.50.

RED CHERRY. Small, for preserves. Pkt. 5c; $1 / 4$ oz. 15c; oz. 50c.

YELLOW PEAR. Small, for preserves. Pkt. 5c; $1 / 4$ oz. 15c; oz. 50c.

YELLOW HUSK (Ground Cherry). Pkt. $5 \mathrm{c} ; 1 / 4$ oz. 15c; oz. $50 \mathrm{c}$.

Book: Tomato Culture, 150 pages, illustrated, $\$ 1.00$, postpaid.

\section{LIVINGSTON'S TOMATO SEED}

In original sealed packages. Direct from Livingston Seed Company. Very select'stock.

LIVINGSTON'S BEAUTY. Per ounce package 35c.

LIVINGSTON'S GLOBE. Per ounce package 35c

LIVINGSTON'S STONE. Per ounce package 35c.

\section{TOPEPO}

\section{TOMATO-PEPPER}

In the Tomato-Pepper (also known as Topepo) we offer a new vegetable with much the shape and size of a large flat tomato. Tomato flavor; pungency of a Mango pepper, though not hot. Can be stuffed as a Mango; sliced in salads; fruit keeping for weeks. Color, vivid red and goldenyellow. Pkt. 10c.

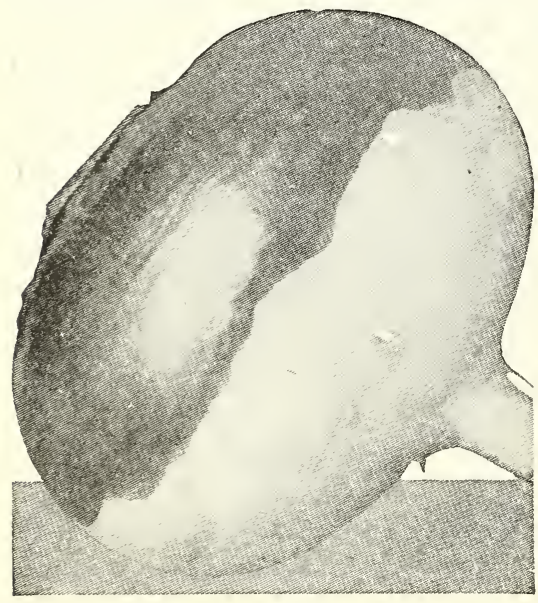

Purple Top Strap Leaf

\section{TOMATO PLANTS}

Ready in May. Per doz. 30c; 100 for $\$ 1.00$; postpaid.

Protect HOTKAP PROTECTORS. Dozen 30c; by mail 35c. 100 for $\$ 1.50$; by mail $\$ 1.65$.

\section{TURNIPS Sweet and Fine}

One ounce for 150-foot row; 2 pounds for one acre.

Plant Turnips between the first of May and the last of July, in rows a foot apart. A quarter-inch of soil is enough to cover the seed. The plants should be thinned out to about five inches apart. Late turnips are generally considered the best. They should be taken out before the first heavy frost, in the fall, and can be packed in boxes of sand to keep all winter.

EXTRA EARLY WHITE MILAN. Flat, very early, productive. Pkt. 5c; oz $10 \mathrm{c} ; 1 / 4 \mathrm{Ib} .35 \mathrm{c}$

EXTRA EARLY PURPLE TOP MILAN. Extra early, flat, turnip-shaped. Pkt. 5c; oz. 10c; $1 / 4$ Ib. 35c.

Purple Top Strap Leaf. The demand for this popular variety is to secure extra selected seed from the most carefully grown stock. It is one of the best turnips on the market. Has a bright purple top, white underneath. Leaves are short, narrow and erect. Flesh white, fine-grained and of mild pleasant flavor. Matures in eight or nine weeks. Pkt. 5c; oz, 10c; 1/4 Ib. 30c.

EARLY WHITE FLAT DUTCH. Good for early, fine-grained. Pkt. 5c; oz. $10 \mathrm{c} ; 1 / 4$ Ib. $30 \mathrm{c}$

Early White Egg "Dependable Grade." An early oval shaped variety with smooth, clear whit SEDDS roots of medium size which grow half out of the ground. The top SE ES $F_{t}$ are small with leaves distinctly cut. The flesh is clear white, firm. are smained and sweet. The roots when in best condition for use are usually about 2 inches in diameter and about $31 / 2$ inches long the most popur fall and winter variety in this market; keeps well. Pkt. 5c oz. 10c: $1 / 4 \mathrm{Ib} .30 \mathrm{c}$.

RED, or PURPLE TOP GLOBE. Much larger than the Purple Top Strap Leaf. A little later and a much better producer. Much liked in Denver market. Pkt. 5c; oz. 10c; $1 / 4$ Ib. 30c.

POMERANIAN WHITE GLOBE. Late, large, fine for table or stock. Pkt. 5c; Oz. 10c; $1 / 4$ Ib. 30c

\section{RUTABAGA}

PURPLE TOP YELLOW. Bangholm stock direct from Copenhagen. Pkt. 5c; Oz, 10c; $1 / 4$ Ib. 30c. 


\section{SPECIAL PRICE LIST}

\section{Garden Seeds In Bulk You Pay The Postage}

These snecial very low prices DO NOT include delivery. If wanted by mail, ADD POSTAGE as per schedule, zone rateg. If wanting varieties in quantities that are not named in this list, please write us.

Washington ARAGUS-Page 29.

Early Giant Argenteuil.

Palmetto

BEANS-Dwarf - Page 29

Stringless Green-Pod, Burpee's.

Improved Red Valentine, Green-Pod

Full Measure.

Bountiful

Golden WVax

Brittle Wax, Round-Pod Kidney

Black WVax.

Burpee's Bush Lima.

Henderson's Bush Lima

BEANS-Pole-Page 29.

Kentucky Wonder.

Kentucky Wonder Wax.

Early Jersey Lima.

BEETS-For Table Use_Page 30.

Early Wonder, beautiful dark red

Detroit Dark Red.

Extra Early Egyptian.

Early Blood Turnip..

BEETS-For Stock Feed-Page 30.

Giant Feeding, or Half Sugar..

Golden Tankard Mangel.

Danish Elvethan, Mammoth Red

Klein Wanzleben, Sugar.

CABBAGE-Page 30 .

Early Jersey Wakefield.

Early Dwarf Flat Dutch

Golden Acre, Select Danish Seed.

Copenhagen Market, Danish

Glory of Enkhuizen, Danish

Danish Roundhead, Hollan
Premium Late Flat Dutch.

\section{CARROTS - Page 30}

Oxheart or Guerande.

Early Scarlet Horn

Chantenay, or Model.

Danvers

CELERY-Page 31

Golden Self-Blanching, French

Giant Pascal, French.

\section{SWEET CORN-Page 31}

Golden Bantam.

Early Evergreen.

Early Minnesota.

Country Gentleman.

Stowell's Evergreen.

\section{CUCUMBERS-Page 32}

Improved Long Green

Snow's Perfection Pickle..

Deltus.

LETTUCE-Page 33.

Los Angeles Market or N. Y. Wonderful.

May King.

Improved Big Boston.

Grand Rapids.

Denver Market.

Hanson

Prize Hed Simpson.

Prize Head.

\section{MUSKMELON-Page 33}

Greeley, Wonder............................... Pollock's 10-2

Rocky Ford Cäntaloupe.

Burrell's Gem .

Hackensack

Improved Hybrid

Honey Dew $\begin{array}{rr}11 \mathrm{lb} . & 5 \text { lbs. } \\ \$ 1.75 & \$ 8.25 \\ .65 & 3.00 \\ .60 & 2.50\end{array}$

10 lbs. $25 \mathrm{lbs}$

$\$ 3.25$

3.25

3.25

3.50

3.50

3.50
3.25

3.00

$10 \mathrm{lbs}$.

$\$ 3.00$
2.40

2.40

$11 \mathrm{~b}$
$\$ 1.00$

$\$ 1.00$
1.00

1.00
.90
.85

5 lbs. 25 lbs. 100 lbs.

$\$ 2.50 \quad \$ 11.25 \quad \$ 40.00$

$\begin{array}{lll}2.50 & 11.25 & 40.00\end{array}$

$\begin{array}{lll}2.50 & 11.25 & 40.00 \\ 2.50 & 11.25 & 40.00\end{array}$

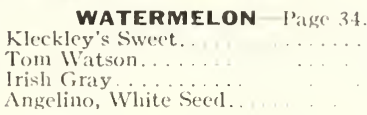

WATERMELON lage 34

Rleckley's Sweet.

Angelino, White Seed.

ONION-Page 34.

Mt. Yellow Danvers, Colorado. Select. $\$ 2.00 \quad \$ 9.50 \quad \$ 18.00$

$\begin{array}{llll}\text { Colorado Red Globe ............... } & \mathbf{1 . 5 0} & \mathbf{6 . 7 5} & \mathbf{1 2 . 5 0}\end{array}$

Large Red Wethersfield............ $\mathbf{1 . 2 0} \quad \mathbf{5 . 5 0} \quad \mathbf{1 0 . 0 0}$

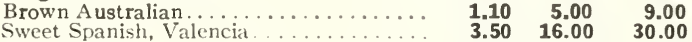

Prizetaker

Silver Skin

Extra Early Barletta

White Lisbon, for bunching

PARSNIP-Page 35

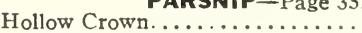

PEAS -Page 35

Alaska, very early.

Gradus

Little Marvel.

Laxtonian

Laxton's Progress

American Wonder.

Dwarf Telephone.

Alderman.

Telephone, Tall. .

PEPPER-Page 35.

Ruby Giant

1 lb. $51 \mathrm{lbs}$

Aninese Giant.

Long Red Cayenne.

Long Red Cayenne.

$\begin{array}{ll}1.80 & 8.50\end{array}$

$3.50 \quad 16.25$

$3.00 \quad 13.75$

$2.50 \quad 11.25$

$\begin{array}{rr}2.75 & 12.50 \\ 1.80 & 8.50\end{array}$

Small Sugar

PUMPKIN-Page 36

Large Cheese - Kentucky Field

Large Yellow Field.

RADISHES-Page 36

$\begin{array}{ll}1 \mathrm{lb} . & 5 \mathrm{lbs} . \\ \$ .80 & \$ 3.50\end{array}$

$.80 \quad 3.50$

$\begin{array}{ll}.80 & 3.50 \\ 80 & 3.50\end{array}$

Saxa.

car

Early Scarlet Turnip, White Tipped.

Early Scarlet T

Crimson Giant. .

Glass (Cincinnati

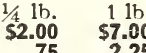

Long Scarlet Short Tarket)

Icicle.

China Rose ivinter.

Round Black Spanish.

Round Black Spanish...

(1bs. 25 lbs. 100 lbs.

$1.80 \$ 4.00$

$\begin{array}{lll}1.80 & 4.00 & 15.00\end{array}$

$\begin{array}{lll}1.80 & 4.00 & 15.00\end{array}$

$\begin{array}{lll}1.80 & 4.00 & 15.00 \\ 3.00 & \mathbf{7 . 0 0} & \mathbf{2 5} .00\end{array}$

$\begin{array}{lll}3.00 & 7.00 & 25.00 \\ 2.50 & \mathbf{5 . 5 0} & \mathbf{2 0 . 0 0}\end{array}$

Long Standin

SPINACH-Page 37 .

Large Thick-Leaved Viroflay

Bloomsdale (Victoria)

Juliana

King of Denmark.

SQUASH-Page 37.

Yellow Summer Crookneck......

Straight-neck Yellow

White Bush Scalloped.

Hubbard

Golden Hubbard......

Acorn or Table Queen.

TOMATO-Page 38

Chalk's Early Jewel.

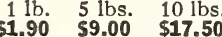

$1.00 \quad 4.50$

4.50

4.25

4.25

4.25
4.50

$11 \mathrm{~b}$.
$\$ 1.00$
1.00

1.10

.90
1.00

.60

1.00

1.00
1.50

$11 \mathrm{~h}$.
5.70
.70
.70
1.00
$11 \mathrm{l}$.
$\$ 2.00$
1.50
1.60
1.20
1.10
3.50
1.40
1.80
1.80
1.80
1.50

$\ldots \ldots$
$101 \mathrm{bs}$.
$\$ 1.75$
2.25
2.25
2.25
2.25
2.25
2.25
2.25
2.25

12.00

16.00

15.00

$1.80 \quad 8.25$

$1.80 \quad 8.00$

1 lb. 5 lbs.

$\$ .65 \$ 3.00$

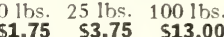

$2.25 \quad 5.00 \quad 17.50$

$5.00 \quad 17.50$

$5.00 \quad 17.50$

5.0018 .09

$\mathbf{5 . 0 0} \quad \mathbf{1 7 . 0 0}$

$\begin{array}{ll}5.00 & 18.00 \\ 5.00 & 17.00\end{array}$

$5.00 \quad 17.00$

$1 / 41 \mathrm{~b} . \quad 1 \mathrm{lb}$.

$1.00 \quad \$ 3.50$

$1.75 \quad 5.50$

$1.25 \quad 3.75$

$\begin{array}{ll}1.25 & 3.75 \\ 1.00 & 3.25\end{array}$

1 lb. 5 lbs.

$\$ .70 \quad \$ 3.25$

$.60 \quad 2.50$

$1 \mathrm{lb} .5 \mathrm{lbs}$

$.90 \quad 4.00$

$.60 \quad 2.75$

$.60 \quad 2.75$

$.65 \quad 3.00$

$\begin{array}{ll}.60 & 2.75 \\ .60 & 2.75\end{array}$

$.60 \quad 2.75$

$.65 \quad 3.00$

$.70 \quad 3.25$

lbs. $25 \mathrm{lbs}$

$\$ 1.50 \quad \$ 6.50$

$1.50 \quad 6.50$

$\begin{array}{ll}1.25 & 5.00 \\ 1.50 & 7.00\end{array}$

$1.60 \quad 7.50$

1 lb. 5 lbs.

$\$ .90 \quad \$ 4.00$

$1.00 \quad 4.50$

$.90 \quad 4.00$

$1.15 \quad 5.00$

$\mathbf{1 . 2 5} \mathbf{5 . 5 0}$

$1 \mathrm{lb}$.
$5 \mathrm{lbs}$.

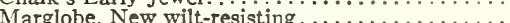

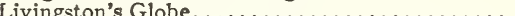

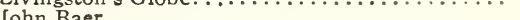

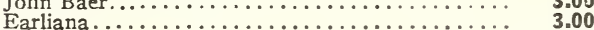

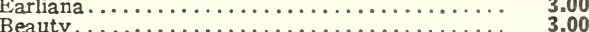

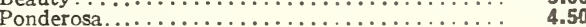

Dwarf Champion.......................

5 lbs.

4.50

5.00

4.50

2.50

7.00

4.50
7.00
TURNIP-Page 38 .

Extra Early White Milan.

Extra Early Purple-Top Milan.....

Purple-Top Strap-Leaf.

Early White Flat Dutch.

White Egg.

Red or Purple Top Giobe.

Pomeranian White Globe....................
$1 \mathrm{lb} . \quad 5 \mathrm{lbs}$

$.75 \$ 3.25$

3.25

2.50

2.50
2.50
2.50

2.50
2.50
2.50 


\section{LAWN GRASS SEEDS}

Values in this line are constantly changing. We give prices here for small quantities. However, when orders are filled we will give customer benefit of lowest market. Ask for Price Current. Let us quote prices when you are ready to buy quantitie.

\section{We pay postage only where priced postpaid}

ALL OUR SEEDS ARE TESTED. We comply with State Seed Law. A 4-page leaflet containing tables of quantities to sow per acre, also weight per bushel, free for the asking. seed is dear at any price-the best is never too good.

\section{SEEDS FOR EVERY LAWN REQUIREMENT NOT POSTPAID UNLESS SO STATED}

We specialize in seeds for lawns, which means we must handle the very best obtainable. Price is second consideration.

SPECIAL LEAFLETS, by C. R. Root. Each free for the asking. How to Make a Lawn. How to Fight the Dandelion Pest. Lawn Pests, How to Eliminate. Bent Grasses, and their uses.

CHAMPION LAWN GRASS MIXTURE. Our best mixture of suitable grasses and white clover in balanced proportions, to make a green quickly and resist dry weather. In sealed packages. $1 \mathrm{lb}$. 50c; postpaid 60c. $10-\mathrm{lb}$. bag $\$ 4.50$; postpaid for $\$ 4.85$.

SHADY NOOK LAIYN GRASS. Especially suitable for shady places. Prepared by us expressly for this purpose; however, it is used siccessfully for open lawns. Contains Fancy 10 Ibs. $\$ 5.50$; postpaid $\$ 5.85$.

SPECIAL MIXTURE TO CROWD DANDELIONS. Contains the creeping grasses and

Dandelions and other

weed pests. Lb. $85 \mathrm{c}$; postpaid $95 \mathrm{c}$; $10 \mathrm{lbs}$. $\$ 7.50$; postpaid $\$ 7.85$.

SUNNYSIDE LAWN GRASS MIXTURE. A combination of fine blade grasses that makes a good lawn that stays good.
Has no White Clover, being Kentucky Blue Grass, Fancy Red Top and Chewing's Fescue. Comes up quick. In sealed packages, $1 \mathrm{lb}$. $45 \mathrm{c}$; postpaid $55 \mathrm{c}$. 3 -lb. bags $\$ 1.30$; postpaid $\$ 1.45$. $10-\mathrm{lb}$. bag $\$ 4.20$; postpaid $\$ 4.55$.

POLO GROUND MIXTURE. Suitable hardy and tough grasses. $10 \mathrm{lbs}$. $\$ 3.00 ; 25 \mathrm{lbs}=\$ 7.00 ; 100 \mathrm{lbs}$. $\$ 25.00$; not postpaid.

EXTRA HEAVY FANCY CLEAN KENTUCKY BLUE GRASS. "Dependable Grade." Exceptionally clean and pure. In postpaid $\$ 3.20$.

KENTUCKY BLUE GRASS. Fancy clean with high germination test and no noxious weed seed. Lb. 55c; prepaid 65c; WHITE CLOYER (Fancy Clean). Our seed is the purest obtainable. To appreciate its quality compare it carefully with others. mail $75 c$. 5 lbs. $\$ 3.00$; postpaid $\$ 3.20$.

WHITE CLOVER (Choice Grade). Average $97 \%$ pure and of good germination. Lb. 60c; 10 lbs. $\$ 5.50 ; 25$ Ibs. $\$ 12.50$. If by mail add postage.

BLUE GRASS AND WHITE CLOVEP. Mixed in suitable proportions. Lb. 60c; 10 lbs. $\$ 5.50$. If by mail add postage. POA TRIVIALIS. Quite similar to Blue Grass in appearance;

Lb. 70c; postpaid 80 c. 10 ibs. $\$ 6.50$. If by mail add postage.

RED TOP (Fancy Hulled). This strictly high-grade seed is Lb. $35 \mathrm{c} ; 10$ lbs. $\$ 3.25: 25$ Ibs. $\$ 7.50$. Add postage.

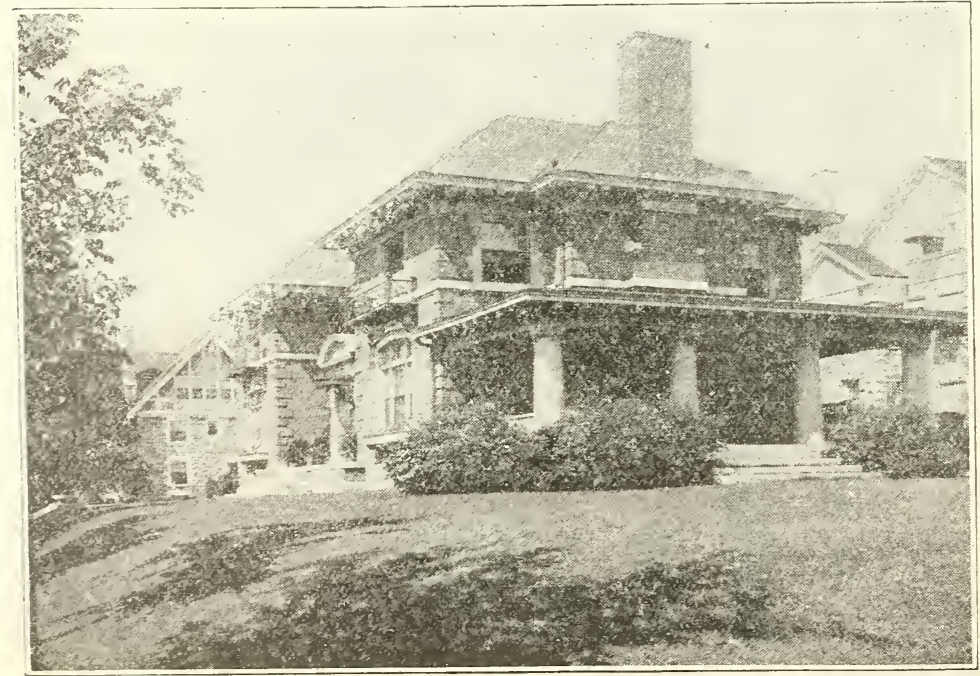

ENGLISH BLUE GRASS (Meadow Fescue). Called by some Herbae Pratti. Quick grower, tough and very hardy; recleaned especially for lawn seed. Lb. $30 c ; 1$
$\$ 5.00$. If by mail add for postage.

PERENNIAL RYE GRASS. Short seeded Pacey's from Ireland. Suitable for lawns. Lb. 25c; 10 lbs. \$2.25; 25 lbs. \$5.00. If by mail add for postage.

RYE GRASS. American-grown. Used in lawn grass mixtures. Lb. 20c 10 lbs. $\$ 1.75 ; 25 \mathrm{lbs}$. $\$ 3.50$. Add for postage.

RED FESCUE. Like most other Fescues this is very suitable in lawns. Its great merit is the fact of its nature of creeping rootlets from which shoots put forth. Being a hardy perennial and of uniform growth, it is highly approved for lawns. A beautiful by mail add postage.

ASTORIA BENT. Very fine blade of a pleasing green color. Very suitable for lawns in Colorado. In sealed packages. $\mathbf{1}$ lb. $\$ 2.00$; 3-lb. pkg. $\$ 5.85 ; 5-\mathrm{lb}$. pkg. $\$ 9.50 ; 10-\mathrm{lb}$. bag $\$ 18.50$ 25-lb. bag \$43.75. Postage extra.

SEASIDE, or COOS BENT. Also called Coocos Bent. A very elect strain dereloped in Washington Makes a very uniform fine-blade lamn grass. 1/4-lb. pkg. 50 c; postpaid; $1 / 2-1 \mathbf{b}$. pkg. $90 \mathrm{c}$, postpaid $95 \mathrm{c}$; $1 \mathrm{lb}$. $\$ 1.75$; by mail $\$ 1.85 ; 10 \mathrm{lbs}$. $\$ 16.50$, by mail $\$ 16.85$.

CREEPING BENT (Imported, German). Light green in color Its nature is to creep, forming superb turf. 1/4-lb pkg. 35c, postpaid: $1 / 2-1 b$. pkg. $60 \mathrm{c}$, postpaid: 1-lb. pkg. $\$ 1.00$, by mail $\$ 1.10$; 10 lbs. $\$ 9.50$, by mail $\$ 9.85$.

COLONIAL BENT. Is small blade and very suitable for lawns. Combines well with the Australian Fescue Grasses. Lb. \$1.10, by mail $\$ 1.20$; 10 lbs. $\$ 10.50$ by mail $\$ 10.85$

CHEWING'S FESCUE. Australian seed. Is a very fine blade an makes a beautiful and lasting green especially good in putting greens; also shady places and poor soils. We recommend it. Lb. 60c; 10 bs. $\$ 5.50 ; 25$ lbs. $\$ 12.50$. Add postage.

BERMUDA GRASS. Used extensively in Southern states, not hardy in Colorado. 1/4 b. 20, postpaid; by mail 60c; 10 lbs. $\$ 4.50$, by mail $\$ 4.85$.

\section{Morton's Pasture Mixture}

MORTON'S PASTURE MIXTURE. Recognized by agronomists as the best well balanced mixture for permanent pasture in Colorado and Wyoming. Contains Orchard Grass, Brome Grass, Meadow Fescue, Timothy and Yellow Blossom Sweet Clover in suitable proportions. Mixed by us. Sow 50 pounds per acre. Per $\mathbf{1 0 0}$ lbs. \$22.00. Less than 50 Ibs. at $24 \mathrm{c}$ per Ib., F. O. B. Denver, Colorado. 


\section{ALFALFA AND CLOVER}

If by mail, add postage, average $5 \mathrm{c}$ per pound

ALFALFA (Grimm). Enough can not he said in praise of this wonderful strain of extremely hardy alfalfa. It seldon winter-kills, the liranclied roots feed its growth rapidly, thus proflucing greater tonnage of hay and likewise a tine stem and leafy growth, making it far superior to tho

greather sood Northern-grown, dependable stock GRIMM. Lb. 45 c: 10 Ibs. $\$ 4.25 ; 25$ Ibs. $\$ 10.25$

A LFALFA (Domestic Fancy). Best standard grade, high test. Lb. 30 c; 10 Ibs. \$2.80; 25 Ibs. 6.7?.

ALSIKE CLOVER. Swedish Clover, fancy, Lb. 35c; 10 Ibs. \$3.25; 25 Ibs. \$7.50.

SWEET CLOVER (White Blossom). Hulled seed, Lb. 15 ; ; 10 Ibs. \$1.25; 25 Ibs. \$2.50

SWEET CLOVER (Yellow Blossom). Colorado-grown. Lb. 15c; 10 Ibs. \$1.25; 25 Ibs. \$2.50. Two important books FREE: "More and Hardier Alfalfa in the Northwest;" "Sweet Clover in the Northwest." While these books cost us money we will be pleased to give either if you are interested.

Inoculate your Alfalfa and Clover Seed with NITRAGIN BACTERIA.

GRASS SEED SOWERS-We carry an assortment. See page 50.

\section{GRASS SEEDS}

тімотнY. Fancy seed, high germination test. Lb. 15c; 10 Ibs. \$1.35; 25 Ibs. \$3.25. Add postage if wanted by mail.

ORCHARD GRASS. Chnice; does well in Colorado. Lb. 30c; 10 Ibs. \$2.60; 25 Ibs. \$6.25. Add postage if wanted by mail.

BROME GRASS-Awnless. Great drought-resister. Lb. 3.c; 10 lbs. \$3.:5; 25 Ibs. $\$ 7.50$.

Add postage if wanted by mail.

SUDAN GRASS. The great forage

Add postage if wanted by mail.

\section{MILLETS}

WHITE WONDER. Improved Coiorado Golden. Recommended for dry land; hardy. 10 Ibs. 60 c: 25 lbs. \$1.25. Ada postage if by mail.

SIBERIAN (Red Russian). Very early and hardy. 10 lbs. 60c; 25 Ibs. \$1.25. Add postage if by mail.

MANITOBA (Hog Millet), Large yellow seed. 10 lbs. 60c; 25 lbs. \$1.25. Add postage if by mail.

\section{FORAGE AND FODDER PLANTS POSTAGE EXTRA IF WANTED BY MAIL, AVERAGE 5C PER POUND}

EARLY AMBER CANE. Best for Colorado. Lb. 10c; 10 Ibs. 7 c: 25 Ibs. $\$ 1$ : 0 .

KAFFIR CORN. White. Lb. 10c; $10 \mathrm{Jbs}$. 50c; 25 lbs. $\$ 1.00$

MILO. Yellow. Lb. 10c; 10 lbs, 50c; 25 lbs. \$1.00.
ESSEX RAPE. English imported; very choice seed. Lb. 20c; 2 Ibs. 35c; 10 Ibs. $\$ 1.50 ; 25$ Ibs. $\$ 3.00$.

Larger quantities any above seeds quoted on application.

\section{GRAIN5}

We issue a Market Price Current, giving prices on all Grass, Grain and Field Seeds in quantity. Ask for it if interested. A leaflet giving quantities to sow per acre, also weights per bushel, free, if asked for.

Postage extra, at zone rates, or average $5 \mathrm{c}$ per pound.

WHEAT (Marquis). The king of early hard wheats. Lb. 10c; 10 lbs. 60c; 25 Ibs. $\$ 1.25$.

BARLEY (Colsess). A new six-rowed, hulled, hooded varicty, outyielding all others. Lb. 10c; 10 Jbs. 60c; 25 Jbs. $\$ 1.25$.

BARLEY (White Hulless or Bald). Usually beardiess. Lb.

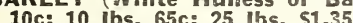

OATS (Swedish Select). The best general crop variety. Lb. OATS (Swedish Select). The

10 c; 10 Ibs. $60 \mathrm{c} ; 25$ Ibs. $\$ 1.25$.
OATS (Victory). A heavy yielding, large white. Lb. 10c; 10 Ibs. $65 \mathrm{c} ; 25$ lbs. $\$ 1.35$.
SPRING RYE. Dry-land raised seed. Lb. 10c; 10 lbs. 60c; 25 lbs. \$1.25.

SPELTZ (Spring Emmer). Especially for dry land. Lb. 10c; 10 Ibs. 60 c; 25 Ibs. $\$ 1.25$.

FLAX. Recleaned seed very scarce. Lb. 15c; 2 Ibs. 25c; 10 Ibs. $\$ 1.00 ; 25$ Ibs. $\$ 2.00$.

For Fall Grain Seed, ask for prices in August.

Copper Carbonate and Blue Vitriol for killing smut in grain seeds, see page 43 .

\section{SEED CORN Suitable for Western Planters}

Pop Corn

Listed on

Page 31

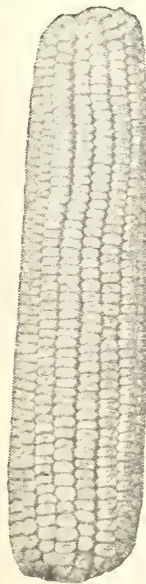

Minnesota No. 13

BOOK- "Seed Corn, do you know that it will grow?" 30 pages with illustrations, Well worth the price of $15 \mathrm{c}$. Free with Seed Corn order of $\$ 2.00$ or more if asked for when ordered.

\section{8 to 10 pounds will plant an acre. Prices for Corn do not include postage.}

Probably no other field crop is more sensitive to acclimation than Corn. Years ago we learned by experience that Corn responds more quickly to selection and acclimation than had previously been considered; thus it is that we now insist on Colorado-grown seed. The higher altitude in which seed matures the better it is for our Colorado use. Accordingly we have selected for purity in type, productiveness and hardiness.

Prices for the following select strains of Field Corn: $1 \mathrm{lb} .15 \mathrm{c}: 2 \mathrm{lbs} .25 \mathrm{c} ; 5 \mathrm{lbs} .50 \mathrm{c} ; 10 \mathrm{lbs} .8 \mathrm{c} ; 25 \mathrm{lbs}$. 51.50. Postage extra.

For larger cuantities, see Pink Sheet price current.

MINNESOTA NO. 13. A truly very desirable variety of Yellow Dent. The ears are of handsome appearance being 16 to 20-rowed, wedge-shaped kernels, growing closely on the cob from butt to tip. Every kernel a good one. The ears are eight to ten inches long, averaging two on a stalk. Matures readily in ninety days; if unfavorable conditions, a hundred days will usually mature it. Is proving itself an excellent drought-resisting variety. We conditions, a hundred days will usually mature it. Is proving itself an excellent drougl

predict that more Minnesota No. 13 will be grown in Colorado than any other variety.
COLORADO YELIOW DENT. For years this name has applied to a good grade of Yellow Dent corn that has been grown in Northeastern and Eastern Colorado. The ear is longer than Minnesota No. 13 but not as large either in kernel or cob. Its chief recommendation is hardiness and reasonably sure cropper.

COLORADO WHITE DENT. Originated near Parker and has been very successfully cropped on the Divide for vears. By all means the best White Dent corn for Colorado, being 12 to 16-rowed, large, broad kernel.

RALIAN. A flint variety, exceptionally hardy and early. Long ears, 8 to 10 inches, usually 8 for dry-land farmers.

\section{MISCELLANEOUS FIELD SEEDS}

\section{Postage extra, at zone rates, see page 64}

BEANS (Great Northern). White Colorado-grom. Lb. 15c; 2 lbs. 25c; 10 Ibs. $51.15 ; 25$ lbs. $\$ 2.50$.

BEANS (Pinto, Mexican). Colorado-grown. Lb. 15c; 2 lbs. 25c; 10 lbs. \$1.00; 25 Ibs. $\$ 2.25$.

BEANS (Soja or Soy). For fodder, early vellow. Lb. $15 \mathrm{c} ; \mathrm{7} 0 \mathrm{lbs}, \$ 1.25$.

PEAS (Colorado Stock or Field Peas). ib. 10 c; 10 ibs. 80 c; 25 ibs. $\$ 1.50$.

PEAS (Cow, Southern Whippoorwill). For fodder. Lb. 15c; 10 Ibs. $\$ 1.30 ; 25$ Ibs. $\$ 2.40$.

SUNFLOWER (Mammoth Russian). Selected for seed. Lb. 20c; 2 Ibs. 35c; 10 Ibs. $\$ 1.25 ; 25$ Ibs. $\$ 2.50$

PEANUTS (Spanish). Small and very early. Lb. $35 \mathrm{c} ; 10 \mathrm{lbs} . \$ 3.00$

PEANUTS (Virginia). Large white. Lb. 30c; 10 lbs. $\$ 2.50$. 
The more our soils are cropped the more attention should be given to replenishing the soil fertility in the form of commercial fertilizers. We urge all planters to consider the needs of their soil.

All fertilizers in sacks cannot be sent by mail; must be transported by express or freight at purchaser's expense. Articles marked (*) can be forwarded by mail when sufficient funds for postage are added to the order.

Odorous fertilizers are not permitted in U. S. mail. Only sealed or carton fertilizers are permissible.

The all-purpose Fertilizer, Ground Cover, Mulch and Soil Rejuvenator

\section{Granulated PEAT MOSS}

IMPORTED FROM HOLLAND-WE HAVE THE GENUINE.

For the information of those who may not be acquainted with the composition of Granulated Peat Moss, and to make certain that all have the same general conception of its nature, which suggests many possible uses, we devote a brief space to a general explanation.

Granulated Peat Moss from Holland is a brown, soft, and spongy matter, formed years ago by the decay of mosses and other vegetable matter. Through drainage this has been left high and dry and today is much used by horticulturists and nurserymen for various purposes. It is clean and easy to handle. No odor whatsoevér.

GENERAL UTILITY USES: Virgin Soil Humus.-It should be added to garden soil which usually

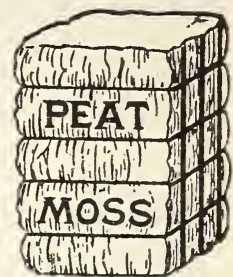
consists of clay, loam, or sand-unsuitable in themseives, yet with this treatment, become excellent for productive

results. Lawns - Late in autumn should have a covering of same, this will almost disappear by spring. Shrubbery-Mix with soil when planting or use as a mulch. Mulching-Will furnish excellent protection against freezing, turning it under next spring. Fine for Rose

\section{8-Page Descriptive Circular Free-Get Yours!}

Trial size. About 12 lbs., $18 \times 12 \times 10$ inches.

Medium or Home Garden Size. About 40 lbs., $23 \times 18 \times 16$ inches.

Large Original Bales. When packed in Holland were 19 to 20 bushels, sufficient to cover 240 sq. ft. area, 1 inch deep. Per bale. 4.50
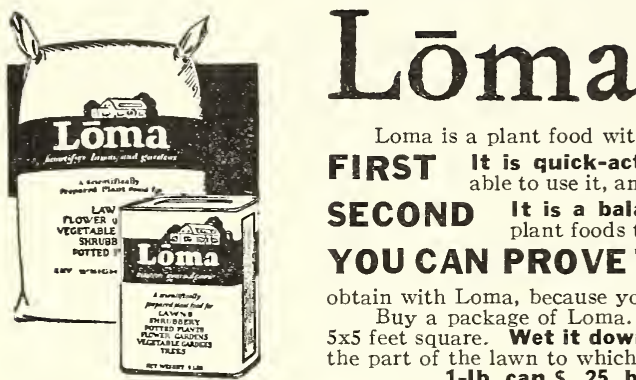

\section{A Finer Lawn}

\section{Better Flowers} Jucier Vegetables

Loma is a plant food with two most unusual and individual features-

FIRST it is quick-acting. A plant food in such form that grass, flowers and vegetables are able to use it, and benefit by it, immediately. You don't have to wait all season for results. SECOND It is a balanced food. Many years of research have resulted in bringing required YOU AN YOU CAN PROVE THEM, TOO But it isn't necessary others as to the really remarkable results you can obtain with Loma, because you can prove these things yourself, and at once.

Buy a package of Loma. Take a pound of it and sprinkle it-like snow-over a spot on your lawn $5 \times 5$ feet square. Wet it down thoroughly, and then, in a week or ten days, note the difference between the part of the lawn to which you have applied Loma, and the rest of the lawn.

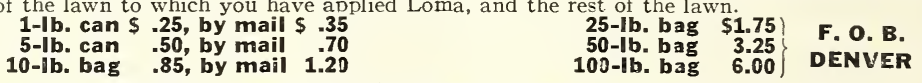

Order your Loma now, because you can use it immediately, regardless of the time of year (Spring, Summer or Fall), and get results immediately. 4 lbs. to $100 \mathrm{sq}$. ft. Directions in every package. Leaflet free.

\section{SHEEP MANURE}

Especially prepared for us. It can be used separately or in combination with the special purpose fertilizer. Sheep Manure is considered a most excellent fertilizer for lawns and truck gardens, and contains no strong odor that usually accompanies animal fertilizers. The drying process kills all germs and weed seeds. This fine manure gets into the ground where needed, and is not eventually raked off as is most of the barnyard products. 100 lbs. cover 500 square feet. $\mathbf{1 0}$ lbs. 25c; 25 Ibs. 50c; 50 lbs. 80c; 100 lbs. at $\$ 1.25 ; 20$ sacks at $\$ 1.10$

\section{ADCO ARTIFICIAL STABLE MANURE}

Each year sees less and less of good stable manure available, thus is more need to procure something that takes its place. The was originally produced in England. It is now available in America. To each 500 lbs, of straw, hay or dried leaves, add 25 lbs. ADCo to make one ton fresh manure. Each package is accompanied by full, explicit directions. The process is so simnle that mistake or failure is almost impossible.

25-lb. bag for $\$ 2.50$, f. o. b. Denver. Add postage at zone rate if $25-\mathrm{lb}$. bag wanted by mail. $150-\mathrm{lb}$. bag for $\$ 12.50$.

\section{NITRATE OF SODA}

Chili Saltpeter. This contains the eal basis for all fertilizers. 1 Ib. 15c; 2 lbs. 25c; 10 lbs. \$1.00; 25 Ibs. \$2.00; 100 lbs. $\$ 7.00 ; 500$ lbs. for $\$ 30.00$. Add postage if small quantity wanted by mail.

\section{VIGORO}

Is a scientifically balanced prepared plant food, containing all the element necessary to grow flowers, vegetables, lawn, shrubbery and trees. Is clean and odorless. Directions in every bag. Leaflet free. 12

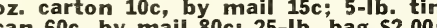
50 -lb. bag $\$ 3.75$; $100-1 \mathrm{~b}$. bag $\$ 6.00$, not 50 -Ib. bas
prepaid.

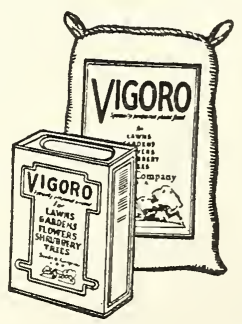

FINE BONE MEAL (Steamed)

An excellent general purpose fertilizer containing 25-30 per cent phosphoric acid and $1 / 3$ per cent ammonia; especially good for sweet peas and other flowers, especially by florists in greenhouse work. 1-lb. pkg. 10c; 5-lb. pkg. 30c; 10-lb. pkg. 50c; 25-lb. sack $\$ 1.00 ; 50-$ Ib. sack $\$ 1.75 ; 100-$ lb. sack $\$ 3.25$.

\section{LIME}

Pulverized, fine, especially good for use on sour soil and where ground worms frequent. It purifies and fertilizes. 6 /bs. 25c 10-lb. sack 40c; original $50-\mathrm{lb}$. sack $\$ 1.00 ; 4$ sacks for $\$ 3.50$. SACCO

The world's leading plant food-a combined soil rectifier and growth producer for use on Lawns, Gardens, Shrubs, Flowers, Trees, Potted Plants and Vegetables. It is a highly scientific and Vegetables. It is a highly scientific preparation containing all the chemito the perfect growth and development of all plants.

Use 2 to 4 pounds per 100 square feet. Full directions for using SACCO are printed on each package.

One Application Produces Amazing Results.

A single SACCO application can be depended upon to make grass and vegetables grow vigorously and to make flowers and shrubbery beautiful with bloom and foliage. This plant food is

almost immediate in results, is easy to

apply and because only a small quantity is required it is very economical.

1-Ib. can
5-Ib. bag

10-Ib. bag

25 , by mail $\$ .35$

25-3b. bag

50-lb. bag 100-ib. bag

$\$ 1.75$ $85 c$, by mail $1.20 \quad 100-i b$.

*EXCELSIOR PLANT FOOD

Peadily in water, no bad odor.

2-oz. can, trial size, $15 c$, by mail 18c. 5-oz. can, 25 c, by mail 30 c. 12-oz. can $40 \mathrm{c}$, by mail $50 \mathrm{c}$.

ITEMS LISTED ON THIS RAGE ARE NOT POSTPAID UNLESS SO STATED; SEE PARCEL POST RATES ON PAGE 64. 
Fertilizers, Continued.

\section{PLANTABBS.}

Concentrated form

plant fertiliz

Sinall size.

Dollar size

Large size

All postpaid.

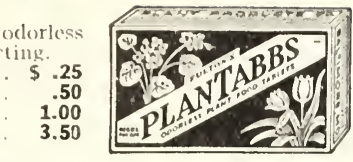

JAPANESE PALM FOOD
and rubber plants. Box 30c, by mail 35c.

* “STIM-U-PLANT"

In all-year fertilizer

trated, odorless and convenient to use. Dissolve one tablet in
quart of water. $\mathbf{1 0}$ tablets for $\mathbf{1 5 c} ; \mathbf{3 0}$ tablets for $\mathbf{2 5 c} \mathbf{1 0 0}$ tablets for $75 \mathrm{c} ; 1,000$ tablets for $\$ 3.50$. All postpaid.

HORN SHAVINGS
For use with ferns, palms, etc., mixed in soil. 1 lb. 15c, by mail 25c; 2-Ib. pkg. 25c, by mail 35c.

\section{*PLANT FIBRE}

For use in growing bulbs and plants indoors. Carton, with cultural directions, 15c, by mail 20c. Bulk, Ib. 15c; 10 Ibs. for \$1.25. Add postage.

\section{SCOTCH SOOT}

Is very effective fertilizer to produce dark green foliage, also strengthens color in blossoms of sweet peas, etc. Very effective $10-\mathrm{lb}$. pkg. 90c, by mail $\$ 1.25$.

\section{SULPHATE AMMONIA}

Much publicity has been given this by Henry Ford. It is a

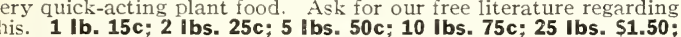
this. 1 Ib. 15 c; 2 -Ib. sack 55.00
INOCULATING BACTERIA

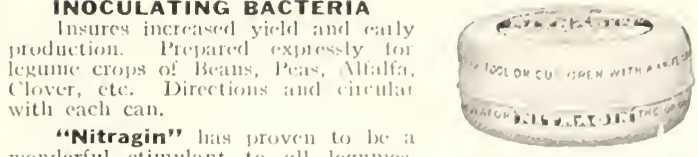

“Nitragin"

It is now put up in such form th

Special Garden Bacteria.

to 8 llas. of seed) for only $\mathbf{2 5 c}$. All postpaid.

Separate Bacteria for Beans, P'('is, Alfalfit

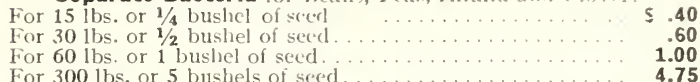

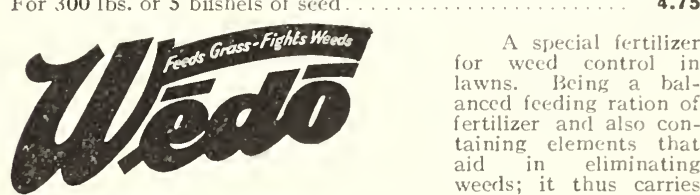

merit. Is ideal for Creeping Bent Lawns. Use one pound to 100

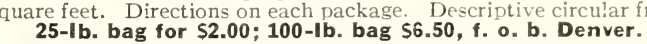

Muriate of Potash, Super-Phosphate, "Vert," Sodium-

Aluminum, and other standard fertilizers in stock and supplied

at market prices.

Please write us when you are interested. .

\section{Insecticides Don't let the bugs get you on the run}

FREE: A Hudson Mouth Sprayer to affix to a bottle. If you order a Dollar's worth or more of insecticides from pages 43,44 and 45 , we give one free if mentioned when ordering.

*Can be mailed if sufficient postage is added to

er.

Our goods comply with requirements of the U. S. Insecticide Laws. Liquids should be sent by express. Where contains poison cannot be mailed. ARSENATE OF LEAD. Very effective with all leaf-eating insects. A very complete and valuable booklet on spraying free with order. $1 / 2-\mathbf{l} \mathbf{b}$. pkg. 25c; 1-Ib. pkg. 4
\$16.00. Poison.

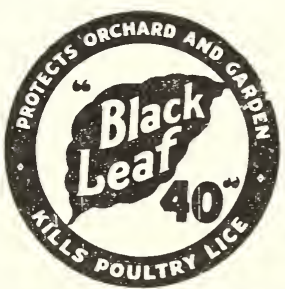

*LIME AND SULPHUR, DRY POWDER. Keeps indefinitely. 1-Ib. carton 30c; 5 -lb. pkg. can $\$ 5.00 ; 100-I b$. box $\$ 15.00$. Add postage.

MELROSINE. Kills rose bugs and other insects on roses. solution. $50 \mathrm{c}$, by mail $\mathbf{5 5 c}$; pt. can $\$ 1.00$, by mail $\$ 1.10$; qt. can $\$ 1.75$, by mail $\$ 1.90$; gal. can $\$ 6.00$. Not prepaid.

BEAN BEETLE DUST. For use as a dust in destroying Mexican bean beetle, potato bug, cucumber beetle and other hard-shelled beetles. 1 ' Ib. carton 30c. Cannot be mailed.

BLACK LEAF "40" (Nicotine Sulphate). Best form of nicotine: 1-ounce bottle makes six gallons, can $\$ 3.75$; 5 -Ib. can $\$ 7.00 ; 10-I b$. can $\$ 11.85$. Cannot be mailed.

BLUE VITRIOL (Sulphate Copper). One pound makes 15 gallons solution. 1-Ib. 20c; 5-Ibs. 85c;

10 Ibs. $\$ 1.50 ; 100$ Ibs. $\$ 11.00$. Poison.
BORDEAUX MIXTURE (Dry). For spraying and dusting; does not deteriorate; see booklet about use. 1 I b. 35c; 4-Ib. pkg. $\$ 1.00 ; 100-$ lb. pkg. $\$ 15.00$. Cannot be mailed.

CARBOLA. A strong disinfectant; excellent whitewash for out buildings. 5-Ib. pkg. 75c; 10-Ib. pkg. \$1.25; 50-Ib. sack $\$ 5.00$. If by mail, add postage.

COPPER CARBONATE. $51 \%$ copper. Highly recommended by State Agricultural College for killing smut on wheat and other grains. Ask for free literature. Lb. 30c; 5 Ibs. $\mathbf{1 1 . 2 5} ; \mathbf{5 0 - I}$. keg. \$10.00. Cannot be mailed.

EVERGREEN. Non-poisonous Insecticide. For killing cabbage worms, cucumber beetle, currant worms, bean beetles, squash bugs, rose slugs, cutworms, mealy bugs, white flies, red spider, all plant

1-ounce bottle.

6 -ounce bottle.

16-ounce bottle.

$\$ .35$, by mail $\$ .40$ 1.00 , by mail 1.10 2.00 , by mail 2.15

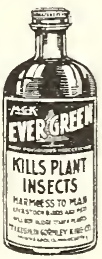

FISH OIL SPRAY SOAP. With caustic potash. Is almost a liquid, and emulsifies quickly. 1/2-gallon
can $\$ 1.00 ; 25-\mathbf{l b}$. keg. $\$ 4.25 ; 100-\mathbf{b}$. keg. $\$ 14.00$.

NICOZFUME, For killing indoor plant $\$$ lice. 8-ib. can $\$ 11.50$. Cannot be mailed.

PARIS GREEN. 1/4-Ib. pkg. 20c; 1-Ib. pkg. 55c; 5-Ib. pkg. \$2.50. Cannot be mailed. The Triple-Duty Spray.
Kills bugs, prevents blight, controls disease,
increases yields. It stimulates growth-lengthens growing season. Easy to use-simply add water, stir, and you are only.
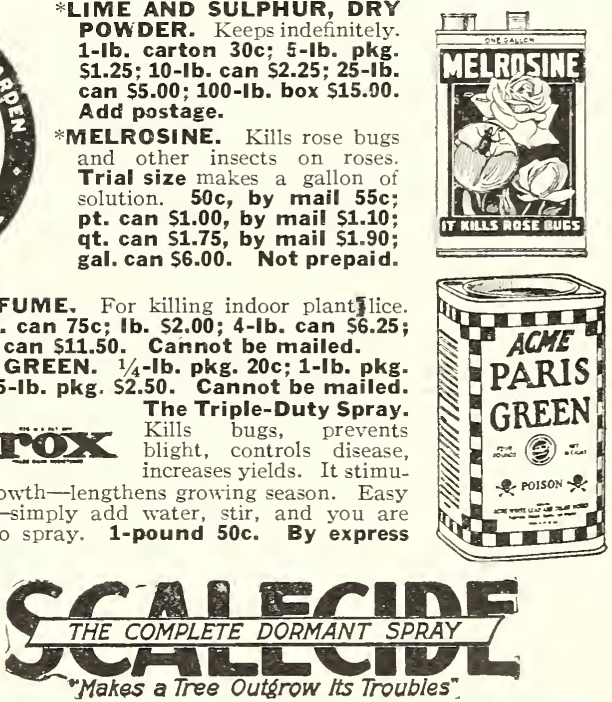

A complete miscible oil spray for use when trees are dormant. to eradicate all forms of scale, especially Elm Scale, also aphis and red bugs on trees. Quart can $75 \mathrm{c}$; gallon can $\$ 1.75 ; \mathbf{5 - g a l l o n}$ can $\$ 6.25 ; 10$ gallons $\$ 10.60 ; f$. 0 . b. Denver.

SUNOCo SPRAY OIL. An emulsion oil for use in killing all kinds of scale on shrubs and trees. A weak solution of Sunoco can be used in summer, especially for red spider. 1-gallon can, $\$ 1.50$; 5 -gallon can $\$ 6.00$; 15 -gallon keg $\$ 13.50$, f. 0 . b. Denver.

SCALE INSECTICIDE. For destroying scale on shrubs, small trees, etc. Made in Denver. Pint can 45c; quart can $65 \mathrm{c}$. f. o. b. Denver.

SEMESAN. A mercuric seed and plant disin-

fectant, used either as a dust or liquid. Controls seed diseases, quickens germination, in vigorates seedling growth and increases crop yields. Excellent for preventing "Damping off." Ask for free literature pertaining to 1 Ib. $\$ 2.75 \cdot 5-1 b$. can $\$ 13.00$. Cannot be mailed.

SEMESAN, JR. A modified dust form for use

on $4-0 z$, can $50 \mathrm{c}=1 \mathrm{lb}$.

\$1.75: 5 Ibs. $\$ 8.00$. Cannot be mailed.

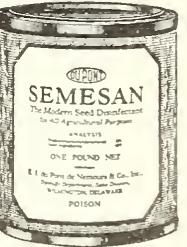

SEMESAN BEL. A dust form that can be used as a dust or liquid.

on potatoes. 1 Ib. $\mathbf{5 1 . 7 5 ; 5}$ Ibs. $\$ 8.00$. Cannot be mailed.

Larger quantities any above on application. All Semesans are trong poisons.

TEMS LISTED ON THIS PAGE ARE NOT POSTPAID UNLESS SO STATED. SEE PARCEL POST RATES ON PAGE 64.

*GRAFTING WAX. In cakes ready for use; good for sores on

*GRAPE DUST. For mildew on plants. 5-Ib. pkg. 95c; 10-Ib. LEMON OIL. Destroys mealy bug, scale and red spider. $1 / 2^{-}$
pint $40 \mathrm{c}$, by mail $50 \mathrm{c}$; pint $\mathbf{7 0 c}$, by mail $80 \mathrm{c}$; quart $\$ 1.25$, by mail $\$ 1.40$.

LIME, POWDERED, HYDRATED. Pkg. 10c; 6-Ib. pkg. 25c;
10 -Ib. pkg. $40 \mathrm{c} ; 50$-Ib. sack $\$ 1.00 ; 4$ sacks for $\$ 3.50$. Add postage. .

\section{(n)}




\section{Insecticides, Continued.}

TERESAN. Dust disinfectant for wheat, oats and barley. 1-lb. can $75 c ; 5-1 b$. can $\$ 3.00 ; 25-1 b$. pail $\$ 12.50$. Cannot be mailed.

SHEP'S PLANT SPRAY. Get rid of destructive insects. Use SHEP'S plant spray. Kills and controls both sucking and chewing insects but
absolutely harmless to humans, birds, animals and pets. Will not "burn" delicate leaves or flowers. Makes green, healthy, lustrous foliage. No soapsud solution needed-simply mix with water. 2-oz. bottle 35c; 8 -oz. bottle 75c; $16-0 z$. bo

SLUGSHOT, MAMMOND'S. Sifter-top can 25c; by maíl 35c; 5-lb. pkg. 75c; 10-lb. pkg $\$ 1.35$. Not postpaid.

*SULPHO-TOBACCO SOAP. For plant lice. 8-oz. cake 25c; 3-0z. cake 15c; postpaid.

SULPHUR, POWDERED. Lb. 15c; 2 lbs. 25c; 10 lbs. $70 \mathrm{c} ; 25$ Ibs. $\$ 1.25 ; 100$-Ib. sack $\$ 3.50$.

TOBACCO DUST. Lb. 15c; 2 lbs. 25c; 5 lbs. $50 \mathrm{c} ; 10$ lbs. $80 \mathrm{c}$; 25 ibs. $\$ 2.00 ; 100-1 \mathrm{~b}$. sack \$6.00. Postage extra.

TOBACCO STEMS. Used to burn as lice killer, and also in pigeon nests. Lb. 10c; 3 Ibs. 25c; 10 lbs. 50c. Postage extra. *TREE WOUND DRESSING. A suitable black paste put up by the Corona Co. Qt. can 75c, by mai $90 \mathrm{c}$; gallon can $\$ 2.50$, not prepaid.

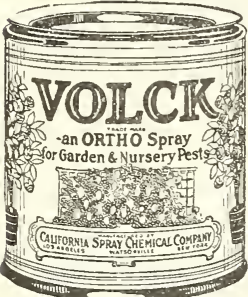

*43" "FOR THE TREES. A black paste; thick paint for use on trees where branches are removed or broken. Used in tree surgery. can $\$ 1.55$, by mail $\$ 1.70 ; 5-1 b$. can $\$ 2.95$, by mail $\$ 3.20$.

*VOLCK. A scientific spray eradicating aphis, thrips, white fly mealy bug, rose mildew and scales on plants. 1/2-pt. can $50 \mathrm{c}$; 1-pt. age extra.
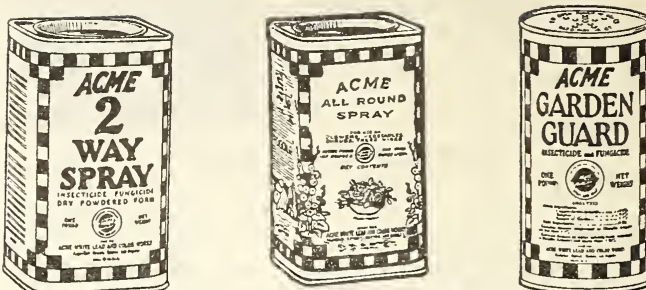

ACME 2-WAY SPRAY. A balanced insecticide and fungicide containing $14 \%$ arsenate of lead and $83 \%$ Bordeaux Mixture, for killing leaf-eating insects and combating blight. Instructions on each package. $1 / 2-l$. pkg. 25c; 1-lb. pkg. 40c; 4-lb. pkg. \$1.25. Cannot be mailed.

ACME ALL-ROUND SPRAY. For the destruction of chewing insects, sucking and fungus diseases. 1/4-lb. can $40 \mathrm{c} ; 1-\mathbf{l b}$. can 90c. Cannot be mailed.

ACME GARDEN GUARD. An insecticide and fungicide for use on vegetables, shrubs and flowers. A powder all ready to apply. 1-lb. sifter-top carton 25c; 5-lb. can 85c. Cannot be mailed.

WILSON'S O. K. PLANT SPRAY. A powerful yet harmless and efficient insecticide for aphis, red spide mildew, scale, etc., for inside and outside spraying. Price, quart $\$ 1.00$, ร.. o. b. Denver.

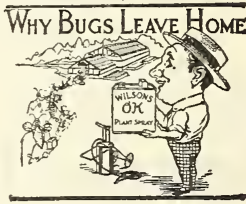

WHALE OIL SOAP (Fish Oif), Used in spraying, 1-lb. pkg $30 c$, by mail $40 c$; $5-16$. pkg. $\$ 1.25$, by mail $\$ 1.45 ; 25-1 b$. box $\$ 4.50 ; 100-1 b$. box $\$ 16.00$, f. 0. b. Denver.

TREE TANGLEFOOT. A very sticky substance to use on bark of trees to prevent insects crawling up. Per 1-lb. can 50 c, by mail 60c.

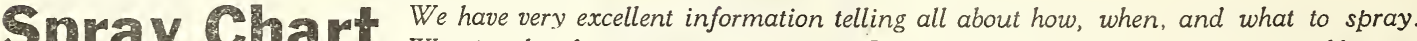
will then mail you suitable literature.

\section{Pest Exterminators}

POISONS CANNOT BE MAILED; Articles marked * can be sent by mail when sufficient postage is adided to order. TELL US WHAT YOU WANT TO KILL; WE WILL MAIL YOU SUITABLE LITERATURE.

ANTROL. The new way to kill Ants. The poisoned bacteria gets to the queen ant and thus destroys the entire colony. A set concots of 4 jars and 4-ounce bottle bacteria. Extra pint bacteria (syrup) 95c: 4 ozs. Extra pint bacteria (syr

TERRO ANT-KILLER. A liquid suitable for both in and outdoors. 2-oz. botties $50 \mathrm{c}$. Can not be mailed.

CYANOGAS (Calium Cyanide). Grade

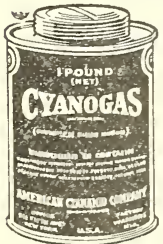
"A" is especially prepared in dust form for use in destroying rats, gophers and prairie dogs, and ants in hills. Is a strong poison and must not be used indoors. $1 / 2-1 \mathbf{b}$. can $45 \mathrm{c}$; lib. can 75c; 5-Ib. can $\$ 3.00$. Can not be mailed.

SODIUM CYANIDE "CYANEGG." Similar to Cyanogas, however is in small eggs, that dissolve readily. One to $3 / 4$ gallon water. $1 \mathrm{lb}$. can contains 16 to $18 \mathrm{eggs}$ 60c. Can not be mailed.

DI-SULPHIDE CARBON. For use in killing ants in lawns, walks, etc $\mathbf{5}=\mathbf{l b}$. can $\$ 2.50$; $1-1 \mathrm{~b}$. can $60 \mathrm{c} ; 1 / 4-1 \mathrm{~b}$. can $25 \mathrm{c}$. Can not be mailed. *PERSIAN INSECT POWDER. This is used in nearly all the popular "fly powders" and house insecticides. Thus we offer it in bulk, to be used in small powder guns, or thrown about loose. Our stock is direct from importers. It is practically pure. Iz $10 \mathrm{c} ; 1 / 4$ b. $250 ;$ b. $80 \mathrm{c}$. Add postage.

ROACH POVDER, PETERMAN'S. Small can 15c; medium can 25c. Add postage.

POISONED WHEAT, SWEENEY'S. In convenient sealed packages, ready to use 2-oz. pkg. 15c; 4-oz. pkg. 30c; large pkg. 60c. Can not be mailed.

POISONED GRAIN. Prepared under formula prescribed at

Agricultural College, especially for prairie dogs, gophers, etc. $21 / 2-1 b$. box

ITEMS LISTED ON THIS PAGE ARE NOT POSTPAID UNLESS SO STATED. SEE PARCEL POST RATES ON PAGE 64.

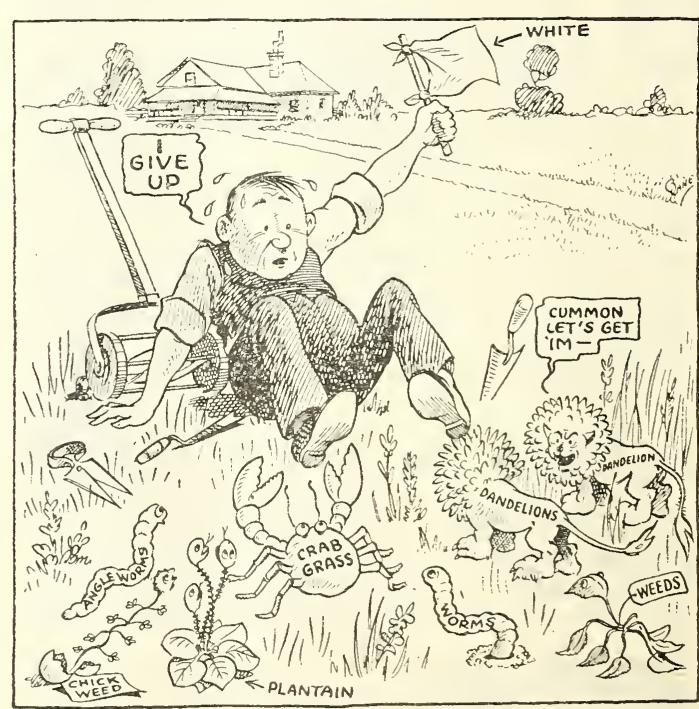

DON'T SURRENDER TO THE LAWN PESTS!! 
Pest Exterminators, Continued.

BAIT-M. A coarse powder preparation put up by Acme Co. Kills grasshoppers, snails and cutworms. Full directions with each
package. Pkt. 35c; 3-lb. pkg. 60c. Can not be mailed.

CREOSOTE. Kills dandelions. 5-gallon can $\$ 3.00 ; 1$ gallon $75 \mathrm{c}$; 2 quarts $50 \mathrm{c} ; 1$ quart 40c. Can not be mailed.

*SODIUM FLUORIDE. For roaches, water

bugs, etc. $1 / 4-I b$. pkg. $15 c$; $1 / 2-I b$. pkg. 25 c; 1-lb. pkg. 45c; prepaid; 5 -lb. pkg. \$1.25, not prepaid.

SULPHATE OF IRON, COPPERAS. F.

SUlPHATE OF IRON, COPPERAS. F.
sulphate, $98 \%$. Powder to use in killing dandelions; use two pounds to one gallon of

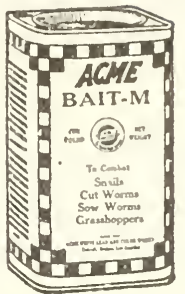
IIater. Lb. $10 \mathrm{c}: 3$ Ibs. $25 \mathrm{c}: 8$
18 Ibs. $\$ 1.00 ; 100-$ Ib. bag $\$ 4.80$.

DIE-U-RAT. A safe rat killer, not a poison, yet very effective. Perfectly safe around chickens and pets. The flavor lures them. Perfectly safe around chicke

"MOUSE SEED." A trade name for a preparation with seeds that kill mice. 2-oz. pkg. 25c; Ib. can $\$ \mathbf{1 . 5 0}$. Can not be mailed.

RAT BIS-KIT. No mixing; they eat it. Per pkg=35c. Can not be mailed.

*RAT CORN. Contains ingredients that will exterminate rats and mice. 4-oz. pkg. $25 \mathrm{c}$, by mail $30 \mathrm{c} ; 8-\mathrm{oz}$. pkg. $50 \mathrm{c}$, by mail $55 \mathrm{c}$

RAT-NIP. A paste form in tubes. Each 35c. Can not be mailed.

STEARN'S RAT AND ROACH PASTE. Per can 35c. Can-

not be mailed.
For Rat and lice Traps, see page 50.

* SHEP'S HOUSEHOLD SPRAY. For moths,

roaches, bedbugs, flies, ants, etc., and keeps 50c: 16-0Z, bottle 75c: quart can $\$ 1.25$.

SNAROL. A poison to kill snails and cutworms by

placing around where these pests frequent. Per placing around where these pests trequent. Per 18 cound pkg. $45 \mathrm{c}$; 3 .

ATLACIDE FUMIGATING CANDLES. Sulphur, slow-burning for 3 hours. Each 15c. By mail 20c.

“ATLACIDE" WEED-KILLER. Exterminates all undesirable vegetation without danger of poisoning of humans or animals. Simply shake powder from can on any undesirable vegetation, weed, grass, etc. Especially recommended for obtaining weed-free Especially recommended for obtaining weed-free can $50 \mathrm{c}$, by mail $60 \mathrm{c} ; 31 / 2-1 \mathrm{~b}$. can $\$ 1.25$, by mail can $50 \mathrm{c}$, by mail $60 \mathrm{c} ; 31 / 2-1 \mathrm{~b}$. can $\$ 1.25$, by mall
$\$ 1.45$. One pound enough for $100 \mathrm{sq}$. ft. For
large area work we supply $50-\mathrm{lb}$. drum $57.00: 100-\mathrm{lb}$. drum large area work we supply 50-Ib. drum $57.00: 100$

PARAFIN WAX. A preparation to use on trees to prevent damage by rodents, borers, rabbits, etc. It drives them away. Full directions on each can. $1-1 \mathrm{~b}$. can $60 \mathrm{c}$; by mail $70 \mathrm{c}$.

PURFECK CHICKWEED ELIMINATOR. A new and efficient product that absolutely combats chickweed and is sprayed on the areas affected by means of any small spraying machine or power sprayer. Kills only the chickweed and does not injure the grass. It requires only mixing with clear water and results are positive. Descriptive circular free. One quart $75 \mathrm{c} ; 1$ gallon \$2.00; not postpaid.

\section{POWDER BLOWERS}

LARGE POWDER GUN, JUMBO. rmwder. 35c; by mail $40 \mathrm{c}$. "DEFENDER." Quick loader; tim: looldt $11 / 4$ ounces nowrer $15 \mathrm{c}$; by mail $20 \mathrm{c}$. HUDSON POWDER BLOWER No. 663. A very satisfactory duster, holding one EELLOWS - No. 11 holds 3 ounces, $\$ \mathbf{1 . 2 5}$; $\$ 1.80$. Postage extra.

HUDSON POWDER DUSTER, MAJOR, No. 665-A

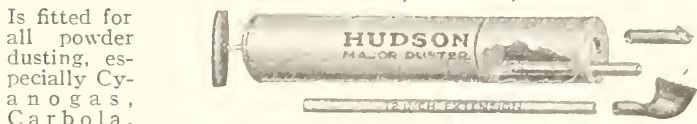

Cacotine powders. Short discharge tube about two inches, plete $\$ 1.25$. By mail $\$ 1.45$.

HUDSON'S No. 665. Without rubber hose as illustrated. $\$ 1.15$. By mail $\$ 1.35$.

\section{DANDELION DESTROYER TOOLS}

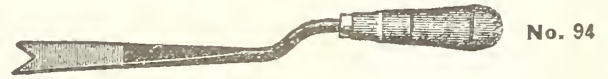

DANDELION KNIFE No. 94. Long, V-shaped blade. Each 40c. By mail $50 \mathrm{c}$.

PLAIN HANDLE DANDELION KNIFE. 12 inches long, over all. V. B. No. 1. Each 30c. By mail $35 \mathrm{c}$.

VILLAGE ELACKSMITH DANDELION KNIFE No. 219 Is very similar to $\mathrm{No} .94$; however, is 15 inches long, with heavier shank and longer handle. Is a very satisfactory tool for use in digging dandelions, roots and branches. Price $40 \mathrm{c}$. By mail $50 \mathrm{c}$.

LONG HANOLE DANDELION KNIFE, $V . B$. No.

220. Is 50 inches long; heavy ash handle. Blade simi-

lar to No. 219. You can stand up and use this tool.

Each 65c. By mail 80c.

MOE'5 DANDELION TROWEL No, 83. Light and durable. 20c. By mail 25c.

REE LEAFLETS: How to Fight the Dandelion Pest, by C. R. Root.

LAWN PESTS. How to Eliminate, by C. R. Root.

Ask for either if interested.

\section{"OUT-U-KUM" WEED PULLER}

A Push and a Pull, That's All.

Out Comes Weed, Roots and All.

The accompanying illustration will

convince anyone of the simplicity and

certainty of extracting the weed without

cutting or breaking the root, thus putting

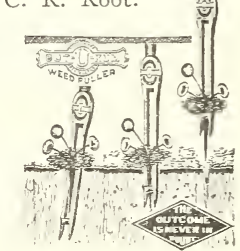

A SURE POISON FOR GRASSHOPPERS.

Mix in the following proportions: 15 lbs. bran, 2 lbs. Paris Green, 1 qt. cheap molasses, 1 qt. water. Mix the bran and Paris Green, unite the molasses and water, then mix together. Place this poisoned dough on fences, elevated boards cutworms by placing it in small lumos about the ground.

We have mixed a quantity of bran with Paris Green that is ready to mix with molasses and water, that we supply in package for 25c. Can not be malled.

\section{Will It Rain Tomorrow? \\ CONSULT THIS \\ Weather Prophet}

It Predicts The Weather For Work Or Pleaslre

Its a fine thing to know in advance just what turn the weather is going to take. The little Weather Prophet will tell you in a very reliable manner Quaint - Practical Get yours FREE with a $\$ 10$ order of Vegetable and Flower Seeds. Ask for it when ordering.

Fine Weather: The two children come out when the weather is to be fine. Rainy Weather: The witch comes out 8 to 24 hours ahead of rain or snow.

The house is made of hardwood, in Swiss cottage style, and is decorate as in the picture, with thermometer, elk's head, bird et $=$. It has four windows and two doors.

SELLS FOR $\$ 1.00$ POSTPAID

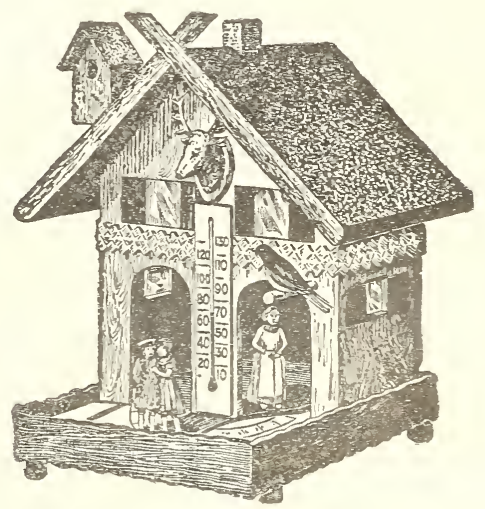

ITEMS LISTED ON THIS PAGE ARE NOT POSTPAID UNLESS SO STATED. SEE PARCEL POST RATES ON PAGE 64. 


\section{Sprayers and Spray Pumps}

HUDSON'S DOUBLE-ACTION “MODOC," No. 132. All brass, high preshose and 12-inch iron extension pipe.

The extension pipes may be added to increase efficiency.

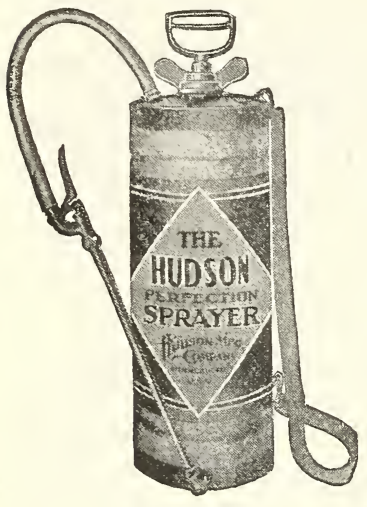

No. 110-G sure bucket pump. Fitted with 3 feet of complete \$4.35. Postpaid for \$4.65.

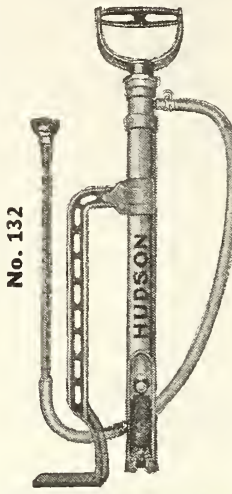

PERFECTION COMPRESSED AIR SPRAYER, Hudson No. 110-G. Knapsack pattern, galvanized tank, 4-gal. capacity; high pressure, quick acting; fitted with universal thread; with 12-inch brass extension. Automatic shutoff nozzle. Weighs 12 lbs. \$6.50.

No. 110-B. Same, with brass Complete, $\$ 9.50$. Either, by mail, 50 c extra.

“LEADER" SPRAYER No. 192-G. Compressed air; quite similar to Perfection, though plainer, with rubber hose and brass extension, and with nozzle soldered on Plain shoulder strap. Holds about 4 gallons. Complete for $\$ 4.25$. By mail $\$ 4.75$.

HUDSON JUNIOR, No. 140-G. Compressed air; very compact and handy; galvanized. Holds $2 \frac{1}{2}$ gallons. Weighs 9 lbs. \$4.65.

No. 140-B. Brass Tank, $\$ 7,00$. Either, by mait, 40c extra.

"BABY JUNIOR," No. 120-G. Compressed air; similar to No. 140-G, holding 2 gallons. Has rubber hose and brass extension, with the nozzle soldered on. Plain shoulder strap. Complete for $\$ 3.75$. Postpaid for $\$ 4.10$.

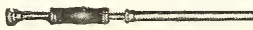

HUDSON TROMBONE, No. 123 Works from bucket, barrel or stream anywhere; is double-acting, continuous spray; complete.

Weighs 4 lbs. $\$ 4.00$. Postpaid for $\$ 4.20$

\section{MYER'S PERFECT KNAPSACK}

SPRAY PUMP. Has galvanized tank holding five gallons. Completely fitted with straps to carry on back. Will work either right or left-hand. Five feet of $3 / 4$-inch hose, stopcock, pipe extension and Bordeaux nozzle. Just the kind for use in greenhouse, also in field. Complete, \$11.CO, f. o. b. Denver.

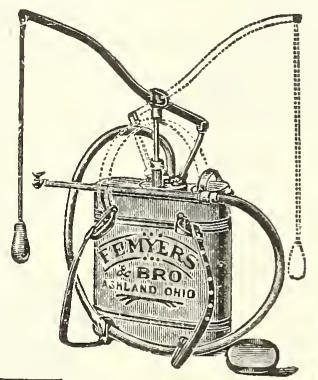

DON'T LET THE BUGS GET YOU ON THE RUN

Free Book on Spraying, "Hudson Tells When, What and How to Spray." 48 pages of practical information. Ask for it.

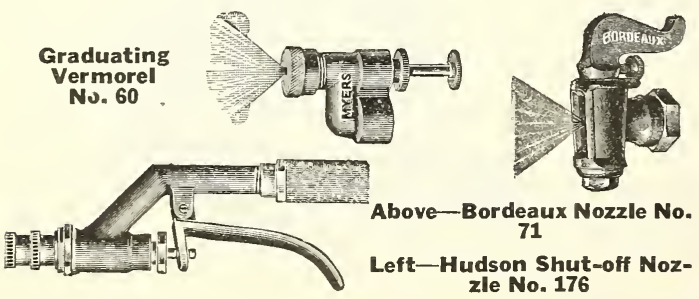

\section{EXTRAS FOR SPRAY PUMPS} NOZZLES-POSTPAID.

HUDSON PERFECTION SHUT-OFF SPRAYER NOZZLE No. 176. Adjustable and suitable for use on all compressed air machines; has $1 / 4$-inch opening. Each $\$ 1.50$, postpaid.

BORDEAUX SPECIAL FAN SPRAY, No, 71. 1/4-inch standard thread. Each $\$ 1.00$, postpaid.

GRADUATING VERMOREL, No. 60. 1/4-inch standard thread. Each $\$ 1.00$, postpaid.

FOG ANGLE APHIS NOZZLE, No. 168. Standard thread. Each 75c, post paid.

SIMPLEX, No. 145. For fine and coarse, with strainer. Each $80 \mathrm{c}$, postpaid.

SPRINKLING NOZZLE, No, 124. Plain sprinkle. Each 40c postpaid.

FIRE NOZZLE, No. 153. Throws 40 to 50 feet. Each 40c, postpaid.

\section{EXTENSIONS AND EXTRAS}

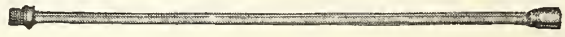

BRASS EXTENSION, No. 172-B. For bucket and knapsack sprayers. 21-inch piece 60c. No. 174 B, 4 feet long, 90c.

IRON EXTENSION, No. 174. 21 inches long, all fitted, $1 / 4$-inch thread; can connect to any sprayer and make convenient lengths. Per 21 -inch piece $40 \mathrm{c}$. Not postpaid.

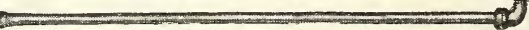

COMBINATION EXTENSION, No. 177-B. Is a 21-inch brass pipe with No. 146 Aphis Fittinus and No. 168 Aphis Nozzle on bent end. All complete for $\$ 1.65$. Not postpaid.

APHIS FITTINGS, ALONE, No. 146. Fits $1 / 4$-inch threads. Each 30c. Postpaid.

EXTRA LEATHER WASHERS, Either make. Each 10c.

\section{RUBBER TUBING FOR SPRAY PUMP USE}

$3{ }^{\prime} 8$-inch size, red, standard, cut to order, per foot....... 121/2c 3/8-inch size, black, 3-ply heavy, cut to order, per foot..... 20. $1 / 2$-inch size, red, standard, cut to order, per foot........ 15c $1 / 2$-inch size, black, 3 -ply, heavy, cut to order, per foot.... 25 c

\section{HAND SPRAYERS}

"FAULTLESS

MISTY," No.

452. Made of

heavy tin, eas-

ily kept in good

order; throws

fine mist; for

use in poultry house, rabbitry and for applying liquids on rose bushes, shrubs, etc.

2 lbs.; holds 1 quart. $45 \mathrm{c}$; by mail $55 \mathrm{c}$

RAINBOW MISTY, No. 455. Similar to

above, with additional spray projector which concentrates mist spray. $60 \mathrm{c}$; by mail $70 \mathrm{c}$.

HUDSON NEW FOG MISTY,
No. 303. Holds one pint, all tin, saves the drip-

pings when held upward. For house spray-

ing. $35 \mathrm{c}$; by mail $45 \mathrm{c}$.

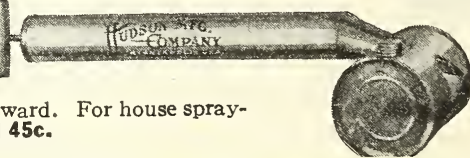

HUDSON MOUTH SPRAYER. A very novel article, suitable for use in throwing a mist spray from a bottle. Only 10c, postpaid.

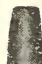

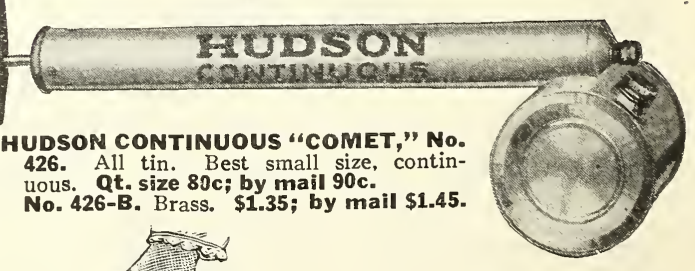

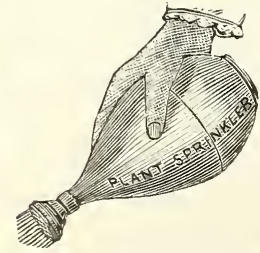

\section{SCOLLAY'S RUBBER}

ATOMIZER SPRAYER

A very convenient small hand spray for use on plants and ferns; also used by florists in flower shops. \$1.25; by mail, $\$ 1.30$. 


\section{Lawn and Garden Requisites}

If any goods on this page wanted by mail, add postage, unless otherwise quoted.

\section{RUBBER HOSE}

We have Garden Hose manufactured under our own brand. True value and sold on merit.

"DEPENDABLE." A strictly high grade of corrugated hose. Full heavy double strand. Fully guaranteed. 5/8-inch, 50 feet, all fitted. Complete $\$ 4.75$. 25 -foot piece for $\$ 2.45$.

We have this also in long coils and cut it to any length to order. $5 / 8$-inch at $11 \mathrm{c}$ per foot; $3 / 4$-inch at $12 \mathrm{c}$ per foot; charging extra $25 \mathrm{c}$ for each fitting.

\section{COUPLINGS AND MENDERS}

“PERFECT CLINCHING", HOSE COUPLING. Best self-fastening coupling on the market, for $1 / 2$-inch, $5 / 8$-inch and $3 / 4$-inch. Per doz. $\$ 2.20$; per set $20 \mathrm{c}$; postpaid.

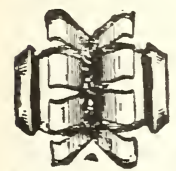

“PERFECT CLINCHING" HOSE MENDERS. Clinches firmly, won't pull apart; for $1 / 2$-inch,
$5 / 8$-inch and $3 / 4$-inch. Each $10 \mathrm{c}$; dozen $\$ 1.10$; $5 / 8$-inch and $3 / 4$-inch. Each $10 \mathrm{c}$;
postpaid. 1 -inch size, each $15 \mathrm{c}$.

postpaid. 1-inch size, each $15 \mathrm{c}$.
COOPER HOSE MENDERS. All brass with reverse.projections which hold firmly. Easily attached. For $1 / 2$-inch hose. Each $10 \mathrm{c} ; 3$ for $25 \mathrm{c}$; dozen $80 \mathrm{c}$; postpaid.

HOSE WASHERS. Regular,size. Per doz. 5c.

\section{NOZZLES}

A full assortment of Nozzles, Sprinklers, Holders, etc., is on our counters at popular prices. The following are leaders BOSTON. All brass, graduated to fine or coarse. $75 \mathrm{c}$, postpaid.

PEORIA. Same style as Boston, adjust. able from very fine to coarse. 50 c, postpaid.

ROUND ROSE. For greenhouse use. 90c,

postpaid.
SMALL ROSE NOZZLE. $21 / 2$-inch face. $40 \mathrm{c}$, postpaid.

SPECIAL ROUND ROSE, "The BOSton." Fine for florists' seedbed use. Each 51.50 , postpaid.

FAN SPRAY NOZZLE (Pasadena Pattern). Suitable to use

HOSE HOLDER. Plain wire bent to suitable shape to hold rubber hose. Each 15c. By mail 20c.

\section{LAWN SPRINKLERS}

LAWN TWIN. Made with brass lining; best. 35c. By mail 40c. SQUARE SPRAY NOZZLE. Corers 30 feet square space. Each $50 \mathrm{c}$. By mail $55 \mathrm{c}$.

REVOLVING LAWN SPRINKLER, "BIRD." Has three arms producing a continuous fine spray, covering 40-foot area. \$1.25. By mail $\$ 1.40$.

ZENITH SPRINKLER. Revolving pattern. Three-arm. Low. DOLLAR REVOLVING SPRINKIER. Very satisfactory for the price. Each $\$ 1.00$; postpaid for 51.15 .

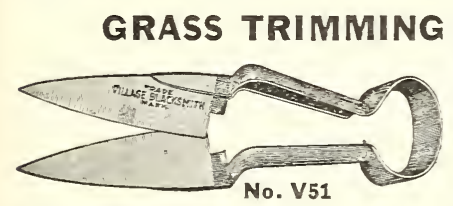

\section{SHEARS}

No. V51. 6-inch. Polished, trowel shank. good tool. $\$ 1.15$. No. V1. 6-inch. Polished, similar style, straight shank. $90 \mathrm{c}$. By mail 51.00 .

No. VB2. Plain, common shears, not polished. 50c, By mail

SERRATED EDGE GRASS SHEARS. Has polished blade, with trowel shank. Malleable handle, and with finger grip. Never needs sharpening ; \$1.25. By mail $\$ 1.35$.

"GRASSNIP" SHEARS, No. 3. Blue enameled malleable handle. A mighty handy tool. Only 75c. By mail $85 \mathrm{c}$

No. 1, V. B. GRASSNIP MALLEABLE HANDLES. 6 -inch polished blades, suitable for cutting light vines, grass, etc. \$1.25. By mail $\$ 1.35$.

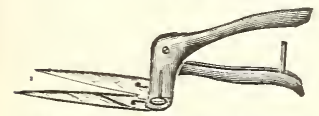

Doo-Klip Grass Shears
DOO-KLIP GRASS SHEARS. 6-inch blade, with easy-working handle.

MINIATURE SCYTHE, or GRASS HOOK, No.3. Handy
around yard. $75 \mathrm{c}$. Cannot be mailed.
GRASS HOOK. Boston pattern, similar to No. 3 only lighter. 50c. Cannot be mailed.

TURF EDGER. Long handle, crescent shape; for cutting turf.

\$1.20.
PLANET JR. No. 2 GRASS EDGER. A very simple but effective LONG HANDLE LAWN TRIMMING SHEARS. The kind where you do not need to lean over to work.
No. 700. 7-inch blades; 36-inch handles. $\$ 2.25$, not prepaid. No. 800. 8-inch blades; 36 -inch handles. $\$ 2.75$, not prepaid.
GRASWIP"

A truly grass

incut tin

grass a n

out stooping to use like a golf stick. Is 37 inches long with 91/4inch blade, and cuts both ways. Weighs only $11 / 4$ pounds; rather difficult to pack for mailing. \$1,00, not prepaid.

\section{WOVEN WIRE}

TRELLIS WIRE. Single, 18 inches wide; for climbers; cut any length. Per foot, $7 \mathrm{C}$.

FLOWER BED BORDER WIRE. 16 inches high. Per foot, 8c; 22 inches high, per foot $11 \mathrm{c}$.

\section{SPRINKLING CANS}

SPRINKLING, or WATERING POT. Heavy galvanized. One gallon 75c; 6 quarts 90c; 2 gallons $\$ 1.10$; 3 gallons $\$ 1.35$.

\section{TREE PRUNING SHEARS}

Convenient for All Kinds of Pruning.

ROCKDALE, No. 45-S. A very popular, serviceable shear; 22 inches long. Strap-handle ferrule. Blunt upper blade, $\mathbf{\$ 2 . 0 0}$ By mail $\$ 2.25$.

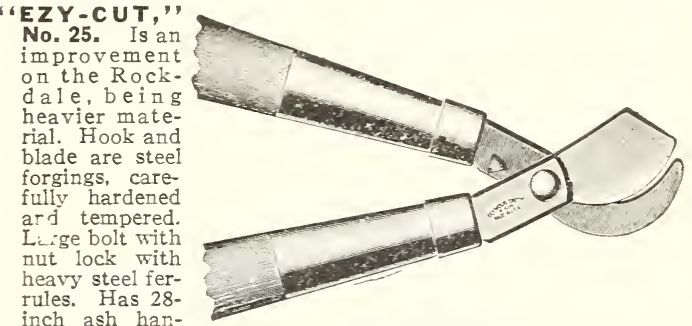
ilen ash han-

pruner we havdle. $\$ 3.25$. By mail $\$ 3.50$

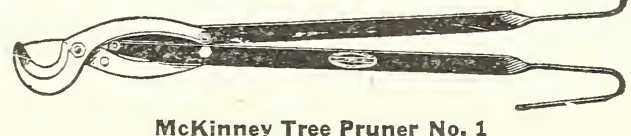

McKINNEY TREE PRUNER, No. 1. This compound leverage pruner will cut 1 -inch hard wood easily. Is wonderfully strong, being all steel; 23 inches long. Cuts very close to the limb. \$4.00. By mail \$4.25.

LONG HANDLE TREE PRUNING SHEARS, "Standard" long rod with lever, for reaching high branches, 6-foot 51.60 8 -foot $51.75 ; 10$-foot $\$ 2.00 ; 12$-foot $\$ 2.30 ; 14$-foot $\$ 2.75$; not prepaid.

Extra cutting blades. Each 35 c, postpaid.

\section{SMALL PRUNING SHEARS}

A large assortment. If by mail add $10 \mathrm{c}$ each.

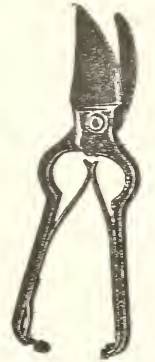

FRENCH PATTERN, No, 39P. 9-inch polished. with flat wheel spring. Especially low price. $\$ 2.00$

V. B. No. 21. Flat spring, ratchet nut, medium grade, polished. $\$ 3.00$.

V. B. No. 14. Flat spring, ratchet nut, medium grade, polished. $\$ 2.50$.

V. B. No. 1409. Brass spring, ratchet nut, black enameled handles. $\$ 1.50$

V. B. No. 179. Polished; 8-inch valute spring.

ladies' shear. \$1,25.

V. B. No. 129. Valute soring, malleable handie. with tool-steel blades. $\$ 1,00$.

V. B. R=, No. 10. 8-inch, with coil spring, painted handle with finger grip. Especially good for soft wood pruning. $75 \mathrm{c}$.

V. B. No. 15, FLOWER SHEARS. 6-inch: all poI GRAPE SHEARS. For cutting buds, etc. Each $50 \mathrm{c}$. By mail $55 \mathrm{c}$. LADIES' ROSE SHEARS. Small pocket style, 6-inch.

No. 20. Polished handles; very neat.

No. 10. Dull finish; plain; very serviceable

$\$ 1.25$

\section{SAWS}

PRUNING SAW, DUPLEX, No. 40

$\$ 1.25$; by mail $\$ 1.40$.

PI.25; b M N 53.

The most popular saw among professional treetrimmers 12

inch 51.15; by mail \$1.30. 14-inch \$1.25; by mail \$1.40. 


\section{Lawn and Garden Requisites, Continued}

Rakes, Hoes and Spades we do not send by mail.

\section{HEDGE SHEARS}

HEDGE SHEARS. Heavy steel iong blades. 8 -inch $\$ 2.00$; by mail 52.25 . 9-inch $\$ 2.25$; by mail $\$ 2.50$.

Ladies' Size. 6-inch. $\$ 1.60$;

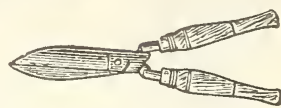

by mail $\$ 1.75$.

"TRIMISNIP" HEDGE SHEARS, ST. 08. Each blade is one piece from tip

to tip of han-

dle, with off-

set tang han-

dles. 8-inch

blaces. Very

$\$ 2.50: 5 y$ mail $\$ 2.75$.

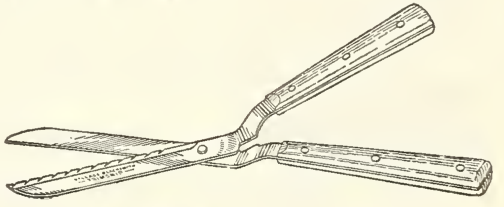

\section{KNEVES}

PRUNER and BUDDER, No. 769P. Folding; two blades. Each

\$2.00, postpaid.
PRUNER and BUDDR, No. 727-W. Folding; 2 blades; white handle. Each $\$ 1.60$, postpaid.

"FOLDING BUDDER," No. 755B. With ivory tip and one budder blade. Each $\$ 1.50$, postpaid.

FLORIST FOLDING, No.
$778-B$. One blade. $\$ 1.00$, postpaid.

FLORIST FOLDING, No, 770-B. One blade; heavy. \$1.25, postpaid.

postpaid.

"Say it with Flowers" on white handle. No. 7725 - $\$ 1.25$, postpaid.

\section{HAND WEEDERS}

Hand Weeders, by mall, $5 c$ each extra.

LANG'S. A very useful small tool: has a finger strap. $25 \mathrm{c}$. MOE'S HAND WEEDER, No. 87. Similar to Lang's. 20c. MAGIC HAND-WEEDER. 3prong $20 \mathrm{c}$; 4 -prong $35 \mathrm{c}$.
SPECIAL MAGIC HANDWEEDER, BB. With 36inch handle. 3-prong. Can use without stooping down. $40 \mathrm{c}$; by mail $50 \mathrm{c}$.

ARGE WEEDING FORK,

No. F 40 V. B. $50 \mathrm{c}$

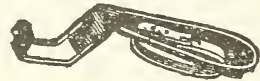

Lang's

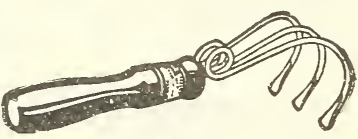

No. 830 . $V$-B.

5 -prong hand weeder, cordle. $M$ u c h liked. $45 \mathrm{c}$; by mail $55 \mathrm{c}$.

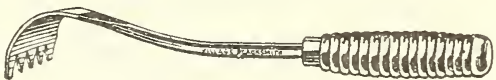

No. $830 \mathrm{~V}$-B.

\section{GARDEN HOES AND CULTIVATORS} Not Prepaid.

S L D SHA N K SOCKET. High grade polished; regular size. Each $\$ 1.00$.

LADIES' HOE. Medium light weight but strong 5-inch. Each 85c.

CLIMAX HOE. A very good low-priced tool. Has ferrule handle, solid shank; black finish. 7 inch. Each 70c.

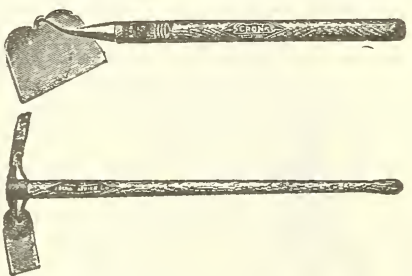

MATTOCK HOE. Heavy; for hard ground. \$1.75.

PLANET JR. LAWN EDGER TOOL. $\$ 1.60$.

WEEDING HOE. One prong, steel blade. Each 55c.

WEEDING HOE. Two prongs, steel blade. Each $60 \mathrm{c}$

WARREN WEEDER HOE. Triangle or heart-shaped hoe. \$1.35.

GARDEN CULTIVATOR (Norcross). Best tool yet for stir ring soil in home garden. 5

5-prong Nor dle. $\$ 1.25$.

No. 33. 3-prong, medium long handle. $90 \mathrm{c}$.

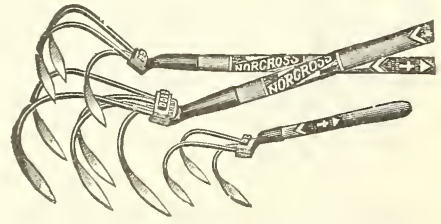

No. 11. 3-prong Midget, with 9-inch handle; very handy tool. 60c. By mail $70 \mathrm{c}$.

BERRY HOOK, No. 99, Has $31 / 2$-foot long handle, thus can reach into clump of bushes. $70 \mathrm{c}$, not prepaid.

GARDEN SPADES AND SHOVELS

\section{Not Prepaid.}

SPADE. Special "Little Giant," medium weight; D handle. $\$ \mathbf{1 . 0 0}$ SPADE. High grade, socket, heavy strap, split handle. \$1.65 SPADING FORK. Good, strong tool, standard grade, " $D$ " handle. $\$ 1.75$.

LONG HANDLE SHOVEL. Strap handle; serviceable. \$1.60.

\section{GARDEN TROWELS}

Trowels, by mail, add $5 \mathrm{c}$ each.

"CHAMPION," FLO-

RISTS', No. 212. All

steel, medium heavy;

good tool; 6 inches long.

$50 \mathrm{c}$.

V. B., No. T-10. Extra heavy, strong and solid. 75c; by-mail $85 \mathrm{c}$

V. B. T., No. 20. Wood handle, riveted, with half-polished 6-in. blade. $30 \mathrm{c}$.

V. B. T., No. 25. Narrow blade; wood handle; 6-in. blade. 20c. SOLID ALL

IRON, No.

80. Regular,

6 -in. $20 \mathrm{c}$.

SOLID ALL

IRON, No.

81. Narrow,

Transplant-

solid $20 \mathrm{c}$.

I R O N

WEEDER,

No. 82. 5 -

prong. $20 \mathrm{c}$.

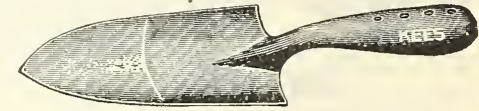

MOE'S DANDY, No. 85. One-piece galvanized iron, remarkably durable. Only 10c: dozen $\$ 1.00$. Postage extra.

TRANSPLANTING HOE TROWEL. 7 inch; wide and flat. Each 35c.

PLANT DIBBER. Steel point, for making holes in ground. Each 70c; by mai 80 c.

\section{GARDEN KIT-Kingsbury}

Four tools of solid one-piece steel construction, packed together in attractive four-color gift carton. Trowel, cultivator, spading fork and transplanting trowel, each one indispensable in the home gardens. Rigidly made for a lifetime of use, yet light and comfortable to handle. Made of bright polished steel, with each handle a different bright lacquer color.

THE BOX COMPLETE \$1.00. BY MAIL \$1.15.

\section{GARDEN SET OF THREE}

No. 711. 1 trowel, 1 weeder, 1 weeding fork. All complete in a box. $50 \mathrm{c}$; by mail $60 \mathrm{c}$

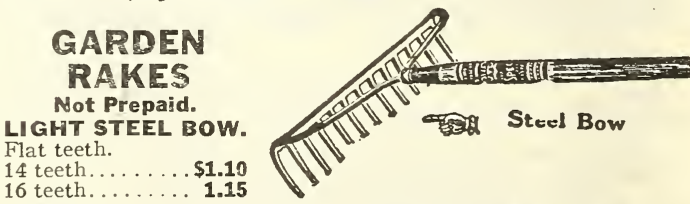

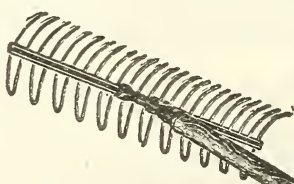

Lawn Rake Queen City
HEAYY STEEL BOW. Extra strong.

12 teeth

14 teeth.

16 teeth.

AWN RAKE, QUEEN CITY. Made double wire teeth on one side, single wire on opposite side: 20 inches wide. Each \$1.00.

IAPANESE BAMBOO RAKE. All bamboo, Very light, though durable. Handy for raking leaves, etc. Only $\mathbf{5 0 c}$.

WOODEN-TOOTH HAY RAKE. For raking lawns. Has 10 teeth. $\$ 1.00$.

DANDELION and LAWN RAKE. STAN DARD. The best yet for use in exterminating dandelions and weeds. Is stout, firm and unbreakable. Braced shanks; 16-inch. Each $\$ \mathbf{1 . 0 0}$ KEE'S No. 621 DANDELION RAKE. 16-inch firm handle, though not braced. Each 90 c.

ITEMS LISTED ON THIS PAGE ARE NOT POSTPAID UNLESS SO STATED. SEE PARCEL POST RATES ON PAGE 64. 


\section{Lawn and Garden Requisites, Continued}

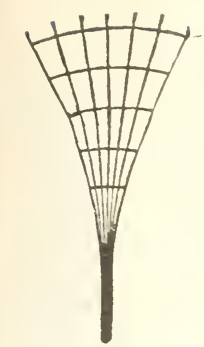

\section{PLANT SUPPORTS}

POSTAGE EXTRA.

FAN-SHAPE TRELLIS. Wood; painted green; all ready for use. 3 feet tall $75 \mathrm{c}$; 4 feet tall $\$ 1.00$.

PLANT SUPPORTS. Vire; made fan-shape. 12 inches across top; 24 inches high. Each 12 inches across tc

CANE STAKES. Bamboo, from Japan, 5 to 6 feet. 10 for $25 \mathrm{c} ; 25$ for $50 \mathrm{c} ; 50$ for $85 \mathrm{c}$; 100 for $\$ 1.25$. Can not be mailed.

GREEN BAMBOO STAKES. Just the thing for supporting tall plants; 3 feet long. 12 for $15 \mathrm{c} ; 100$ for $60 \mathrm{c}$.

$21 / 2$ feet long- 12 for $15 \mathrm{c} ; 100$ for $50 \mathrm{c}$.

2 feet long- 12 for $15 \mathrm{c} ; 100$ for $40 \mathrm{c}$.

SWEET PEA TRELLIS WIRE. Cut to any lengths.

36 inches wide.

48 inches wide. Per foot.

60 inches wide. Per foot.

$5 c$
$6 c$

AHLIA STAKES, 5 feet $x 1$ inch 1 8c green. Heavier material than the factory-made. Each 15c; dozen $\$ 1.50$; per $100 \$ 10.00$.

\section{PLANT STAKES}

PLANT STAKES. Especially suitable for all kinds of garden flowers. Are square, painted green, pointed one end. "Factorymade."

Size, 3 feet long. Each $8 \mathrm{c}$; doz, 85c.

Size, 4 feet long. Each $10 \mathrm{c}$; doz. \$1.10.

Size, 5 feet long. Each 13c; doz. $\$ 1.45$.

Size, 6 feet long. Each $17 \mathrm{c}$; doz. $\$ 1.80$.

\section{PEONY AND TOMATO SUPPORTS}

ADAMS' PEONY AND TOMATO SUPPORTS. Made of strong

No. 6. 18-inch diameter. Each 40 c; doz. $\$ 4.20$.

No: 7. 14-inch diameter. Each 35c; doz. \$3.60.

\section{GARDEN MARKERS}

EVERLASTING GARDEN MARKERS. Galvanized: 9-inch. Each $5 \mathrm{c}$; dozen $50 \mathrm{c}$; $100 \$ 3.50$. Add postage. Galvanized: 19 inches long. Per dozen $\$ 1.00$; per $100 \$ 7.50$.

INK for indellible marking. Per bottle 60 c.

COPPER LABELS. $5 \times 11 / 8$-inch; wired to iron stakes. 10-inch long stakes, 12 for $50 \mathrm{c} ; 50$ for $\$ 1.50 ; 100$ for $\$ 2.75$. 14-inch long stakes, 12 for $60 \mathrm{c} ; 50$ for $\$ 1.90 ; 100$ for $\$ 3.50$. Postage extra at zone rates.

"BIRD" STAKES. Excellent representation of birds, cut out of wood, and painted; on long stakes. Make very attractive garden markers. Six assorted in box. Single label for 35c; 3 for $\$ 1.00$; original carton of 6 for $\$ 1.80$. Pošage extra, each $10 \mathrm{c}$; six for $35 \mathrm{c}$.

\section{POT AND GARDEN LABELS}

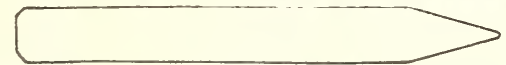

Postage extra on labeis, unfess priced otherwise.

For use in labeling rows where bulbs and seeds are planted. These wooden labels are pine with special oil treatment, being better than painted.

Pot, 4-in., 1.000 in a box.

Pot, 6-in., 500 in a box.

Pot, 8-in. x 13-16 in., 500 in a box.

$\begin{array}{rrr}\text { Per } 12 & 100 & 1.000 \\ \$ .05 & \$ .25 & \$ 1.30 \\ .05 & .30 & 1.96 \\ .10 & .75 & 3.50 \\ .15 & .90 & \mathbf{5 . 2 5} \\ .15 & 1.00 & 8.50 \\ .40 & 3.00 & \ldots \ldots \\ .05 & 30 & 1.70\end{array}$

GARDEN STAKE LABELS. 12 -in.

1 1/8-in., 100 in a box

GARDEN STAKE LABELS. $18-i n . x i \frac{1}{2}$ inch.

TREE LABELS. $3 \frac{1}{2}$-inch. ; copper wired.

1.000 in a hox

ALL-COPPER TREE LABELS."3 3 3 3/4-inch. Wired complete last forever. 12 for $35 \mathrm{c} ; 50$ for $\$ 1.00 ; 100$ for $\$ 1.75$; postpaid. A stvius marker free with order for one hundred.

WEATHER-PROOF CARBON PENCILS. Heavy black, for use with labels. Does not fade or wash off. Each $10 \mathrm{c} ; 3$ for 25 c; 12 for 80 c; postpaid.

\section{KNEELING PADS}

Sponge rubber, one-half-inch thick; for all kneeling purposes: equipped with eyelet. Each $50 \mathrm{c}$; postpaid for $55 \mathrm{c}$.

\section{RAFFIA}

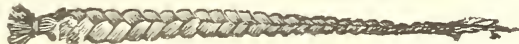

RED STAR. Natural in skeins weighing from $11 / 2$ to $21 / 2$ pounds excellent for tying up plants, grafts, etc.; in original skeins;

$31 / 2$ feet long. Per lb. 35 ; less original skeins, per Ib. 40 c; by mail $5 \mathrm{c}$ per lb. extra.

$\mathbf{X X X}$. Extra long -5 feet. In skeins at $40 \mathrm{c}$ per lb. Less skein to lot at $50 \mathrm{c}$ per Ib.

\section{VINE HOOKS}

VYN-TACH. For wood. Driven in like nails, then $5 \mathrm{c}$; doz. for $50 \mathrm{c}$.

VYN-TACH.

sonry. Dryvin shells, for inserting in drilled holes. together with hook. Each $15 \mathrm{c}$; 2 for $25 \mathrm{c}$; $\$ 1.20$ per doz. Original boxpacked 25 hooks, 25 Dryvins, 1 Drill and 1 holder to box, for $\$ 2.50$.

Descriptive circular on request.

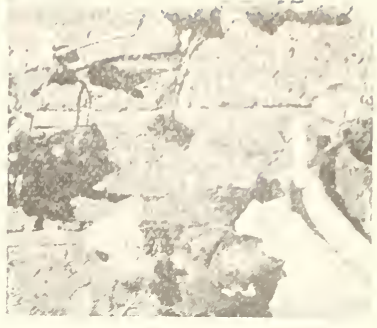

Vyn-Tach Hooks on Masonry

\section{PLANT BANDS}

Add postage at zone rates.

Made of fibre, scored at corners, shipped flat, are all ready for use.

Size No. 2. $2 \times 2,21 / 2$ inches deep. Per $10045 \mathrm{c} ; 1,000$ $\$ 3.45$; case of 5,000 for $\$ 12.50$.

Size No. $3.3 \times 3,3$ inches deep. Per 100 50c; 1,0C0 \$4.85; case of 2,500 for $\$ 9,60$.

Size No. 4. 4 × 4, 3 inches deep. Per 100 65c; 1,000 \$5.90; case of 2,000 for $\$ 8.60$.

PAPER POT BANDS. $3 \times 3.100$ for $75 \mathrm{c} ; 1,000$ for $\$ 6.00$.

\section{HOTKAP PLANT PROTECTORS}

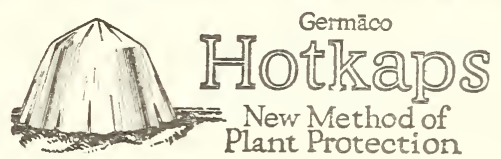

Matures crops earlier; shields plants from wind. rain and light rosts; protects them from insects; keeps dirt soft-miniature "hothouses." A revolutionary device that saves much in time. labor and money. 1,500 Hotcaps used on an acre, average.

Full directions in free circular

Dozen for $30 \mathrm{c}$; by mail $35 \mathrm{c}$. 100 for $\$ 1.50$; by mail $\$ 1.65$. 1,000 for $\$ 11.50$, not prepaid.

"Trial Box," consisting of 250 Hotcaps with one new style Garden Setter made of fibre for $\$ 4.00$; by mail $\$ 4.40 ;$ Garden Setter alone $50 \mathrm{c}$; by mail $60 \mathrm{c}_{\mathrm{r}}$

HOTKAP SETTERS. Metal. Used when large quantities are set. $\$ 2.5 C$; by mail $\$ 2.75$.

HOTKAP TAMPER. A special steel tool to use in placing soil over edge of Hotkap, instead of using hands. Very suitably constructed. $25 \mathrm{c}$; by mail $30 \mathrm{c}$.

\section{HARRIS FROST OR SUN PROTECTORS}

Made from black shinv weatherproof paper, which will last for many seasons. We supply them flat with a stake for locking the edge and anchoring to the ground. 12 inches high, 10 inches wide at bottom. 25 for $\$ 1.75 ; 100$ for \$4.00; 500 for $\$ 18.00$. Postage extra; 25 weigh 5 pounds.

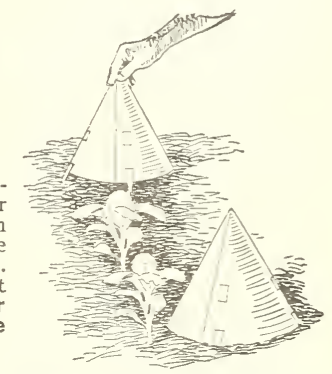

\section{MULCH PAPER-NOX WEED}

A much-talked-about article for use in spreading over ground to conserve moisture, keep down weeds and lessen labor in cultivating and hoeing.

GRADE “A." is light, for annuals. 300 linear yards in roll; 18 inches wide, per roli $\$ 3.50 ; 36$ inches wide, per roll $\$ 6.50$. GRADE “B," is heavy, for perennials. 150 linear yards in ro!

18 inches wide, per roll $\$ 3.50 ; 36$ inches wide, per roll $\$ 6.50$.

\section{HOTBED COVERING}

HOTBED COVERING. Glass Cloth and Screen Glass (VioRay). See full description on page 54. 


\section{Lawn and Garden Requisites, Continued TWINES}

TWINES ARE F. O. B. DENVER

JUTE. 3-ply. 1/2-lb. balls; for tying vegetables. 1 ball 20c; 2 balls 35c; 5 Ibs. at 30c per lb.; 25 lbs. at 27c per Ib. COTTON, WHITE. 4-ply; small balls. Lb. 50c; 5-lb. bag for $\$ 2.25$. On cones, about $21 / 2$ pounds, $\$ 1.00$.

MANILA. Heavy, for large packages. 50-lb. reels at 33c per lb. BINDER TWINE. Used for many purposes in tying. 8-lb. bali $\$ 1.25 ; 50-\mathrm{lb}$. bale $\$ 6.75$. Subject to market price.

BAG SEWING TWINE. 3 and 4-ply, in 4-oz. skeins. Each 20 c; 4 skeins 60 c.

SEWING NEEDLES. Bent. 6-inch. Each 10c: 3 for 25c; postpaid.

\section{ANIMAL TRAPS}

MOUSE TRAPS, "SPRING." Bait with cheese. 12 for 35c 3 for 10 ; postpaid. RAT TRAPS, “SPRING.” 2 for 35c; each 20c; postpaid.

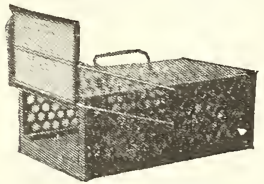
SPRING FLOOR RAT TRAP. Take one or several at a time, and catches the last one successfully. Has done wonders in our warehouse. Has a wonders in our warehouse. Has a clever yet simple spring foor that
closes the door. \$1.00, postpaid.

Spring Floor Trap DROWNING CAN. You better run the rats into the can, then drown them, and keep the trap dry. 50 c.

GOPHER TRAPS, MAC ABEE. Very simple. 35c, postpaid.

ABINGDON O-K GO. PHER TRAP. A trap in

a box. $45 \mathrm{c}$, postpaid.

For Rat Poisons, see pages 44,45 .
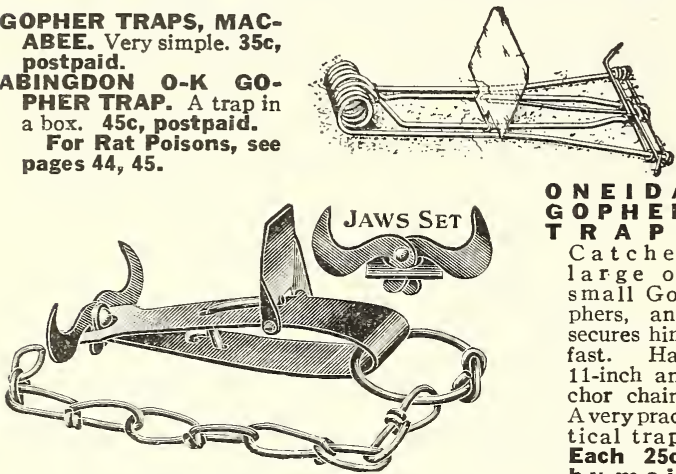

O N E I D A G R P P P R Catches large or small Gosmall Gophers, and fast. Has 11 -inch anchor chain. A very practical trap. bach $25 \mathrm{c}$ : $30 \mathrm{c}$.

\section{Handy Home}

SEED SOWERS AND PLANTERS

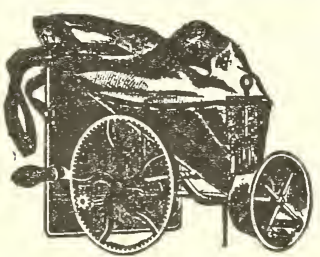

CAHOON'S PATENT HAND SEED SOWER. For sowing alfalfa, clovers, wheat, oats, barley, rye, grass seeds, etc. The seed is thrown from 8 to 20 feet on each side of the operator. Weight, $91 / 2$ lbs. Each $\$ 4.50$; postpaid $\$ 4.75$.

CYCLONE HAND SEEDER. Does the work of larger capacity seeders equally as well and costs much less. Weighs 5 lbs. Price \$2.00: postpaid $\$ 2.25$.
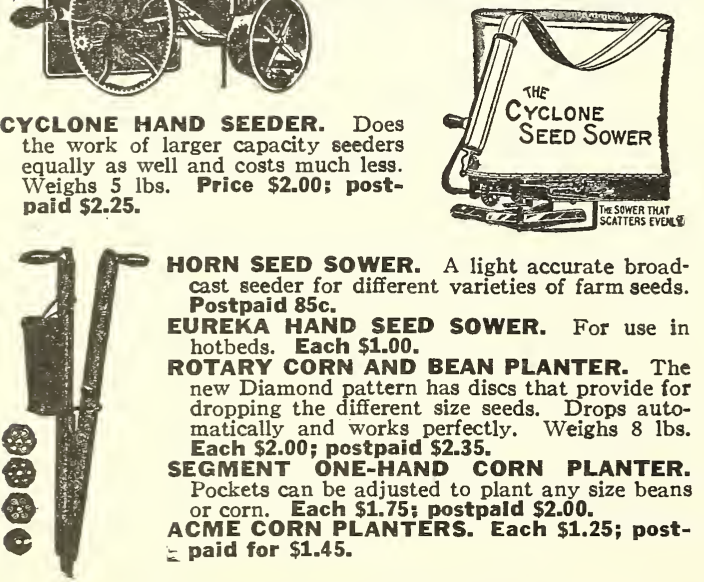

CORN HUSKING TOOL

A glove arrangement to fit the right hand to use when husking corn to help in pulling down the husk. Each 30c; postpaid. ITEMS LISTED ON THIS PAGE ARE NOT POSTPAID UNLESS SO STATED. SEE PARCEL POST RATES ON PAGE 64.

\section{No. 5981}

HOTBED, or MUSHROOM, No. 5981 (Tycos). Wood case with handle. pointed metal end. Very durable. 15-inch. \$2.50.

For Incubator Thermometers, see page 52

\section{HYGROMETERS}

Postpaid.

Tycos instruments are very dependable.

No. 5532. MASON'S. Two magnifying thermometer tubes, with water bottle, all mounted on hardwood. Ornamental. Gives humidity on easily read scale. $\$ 4.00$.

No. 5558. AUTOMATIC. Two thermometer tubes like No. 5532 , with easy reading table attached. Very complete. $\mathbf{\$ 8 . 5 0}$. No. 5570. PRECISION HAIR HYGROMETER. 5-inch diameter; dial hair indicator. Hangs. \$7.50.

\section{MISCELLANEOUS SUPPLIES}

GLAZING POINTS, PERFECTION. 1,000 in box. No. $21 / 2$. Per box 60c; 10 boxes for \$5.50. Postage extra, 5c per box. GLASS CUTTER, FLETCHER'S. Does good work. Each 25c. GLAZING CEMENT, PUTTIUM. A popular elastic glazing cement: gray. 1-gal. can \$2.50; 5-gal. can $\$ 12.00$.

GLAZING MACHINE. For one-hand use in applying glazing material. 5 lbs. $\$ 5.00$

SCOLLAY'S RUBBER PUTTY BULB. Latest pattern. Each $\$ 1.25$; by mail $\$ 1.30$.

PUTTY KNIFE. Standard style. Each 35 c, postpald.

GRAFTING WAX. 1/4-Ib. cake 20c; $1 / 2-1 \mathrm{~b}$. cake 30c; Ib. cake 50 c; postpaid.

\section{Implements}

\section{CORN SHELLER} AND GRIST MILL BLACK HAWK CORN SHELLER. The greatest little corn sheller ever made. Shells any size thoroughly. Can't be beat for the price. Weight. 15 lbs. $\$ 3.25$; postpald $\$ 3.75$.

BLACK HAWK GRIST MILL. A hand mill for country, village and city use. Grinds corn, rye, spices, etc., easily and fast. Soon pays for itself. Just the thing for poultrymen. Weight, 18 lbs. \$3.50; postpaid $\$ 4.00$.

\section{IRON KING GARDEN CULTIVATOR}

STYLE No. K-44.

Has a high wheel, 24 inches in diameter, insuring easy working. The handles are adjust able to ajust able to fit a operator. quipped wit moldboard plow, weeder and cultivator combined, making popular garden tool. The other attachment has three teeth. has three teeth. and by reversing makes a 9-inch scuffle or weeding hoe. Just the thing for backyard gardens. Weighs 20 lbs. Not packed for mailing. PRICE, ONLY $\$ 3.00$ F. O. B. DENVER
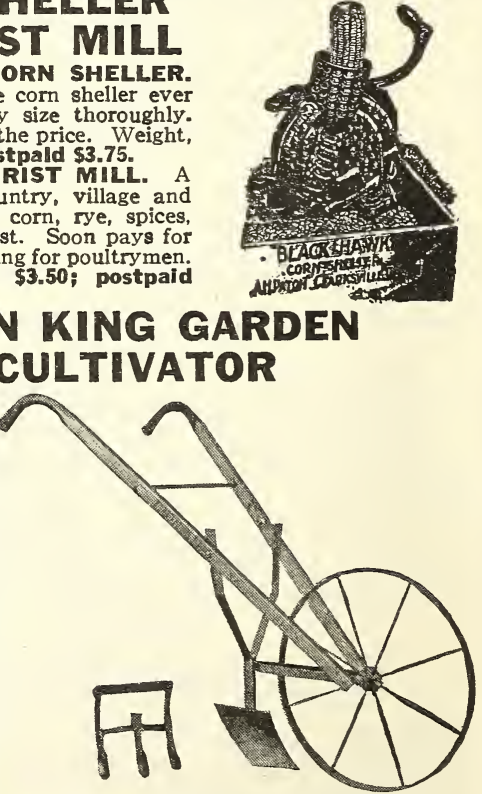


\section{Pots, Tubs, Porch Boxes}

This Pottery cannot be mailed except with heavy packing and great cost of postage extra.

Six of any kind sold at dozen rate; 50 at hundred rate; 500 at thousand rate. Packing of pottery is charged extra at actual cost.

\section{FANCY FLUTED WHITE FLOWER POTS}
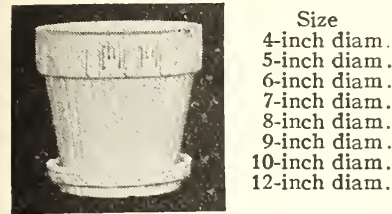

Each Doz. 100 $.121 / 2 \quad 1.20 \quad 7.00$ $\begin{array}{lll}.18 & 1.60 & 9.60\end{array}$ $\begin{array}{lll}.25 & 2.35 & 15.60\end{array}$ $.35 \quad 3.50 \quad 24.00$ $.50 \quad 4.85 \quad 33.00$ $\begin{array}{rr}60 & 5.50 \\ . & \ldots .\end{array}$

\section{FANCY FLUTED WHITE SAUCERS}

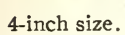

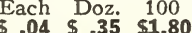

5-inch size.

$\begin{array}{lll}.05 & .50 & 3.80\end{array}$

6-inch size.

7 -inch size

8-inch size.

10 -inch size

12-inch size.

$\begin{array}{lll}.08 & .70 & 5.00\end{array}$

$\begin{array}{lll}.12 & 1.10 & 7.80\end{array}$

$\begin{array}{lll}.15 & 1.60 & 12.00\end{array}$

$\begin{array}{lll}.20 & 2.15 & 16.50\end{array}$

$.30 \quad 2.65$

$.25 \quad \cdots$

STANDARD RED FLOWER POTS

\begin{tabular}{|c|c|c|c|c|}
\hline $\begin{array}{c}\text { Size } \\
\text { 2-inch... } \\
\text { 21/2-inch } \\
\text { 3-inch... } \\
\text { 4-inch... } \\
\text { 5-inch... } \\
\text { 6-inch... } \\
7 \text {-inch... } \\
\text { 8-inch... } \\
\text { 9-inch... } \\
0 \text {-inch. }\end{array}$ & $\begin{array}{c}\text { Each } \\
\ldots \ldots \\
\therefore .05 \\
\$ .05 \\
.06 \\
.10 \\
.15 \\
.20 \\
.30 \\
.40 \\
.50\end{array}$ & $\begin{array}{r}\text { Doz. } \\
\$ .25 \\
.30 \\
.40 \\
.60 \\
1.00 \\
1.50 \\
2.00 \\
3.00 \\
4.00 \\
5.00\end{array}$ & $\begin{array}{r}100 \\
\$ 1.00 \\
1.50 \\
1.85 \\
3.00 \\
5.75 \\
8.00 \\
14.00 \\
21.00 \\
29.00 \\
37.00\end{array}$ & $\begin{array}{r}1,000 \\
\$ 9.00 \\
13.00 \\
16.00 \\
26.00 \\
50.00 \\
72.00 \\
125.00 \\
190.00 \\
260.00 \\
330.00\end{array}$ \\
\hline & 1.00 & 9.0 & & \\
\hline
\end{tabular}

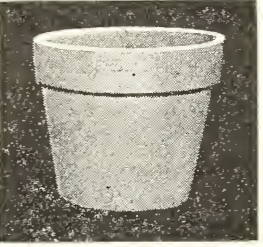

STANDARD RED SAUCERS Size

4-inch.

5-inch.

7-inch.

8-inch.

9-inch.

12-inch.

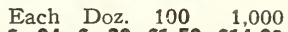
$\begin{array}{lllll}\$ .04 & \$ .30 & \$ 1.50 & \$ 14.00\end{array}$ $\begin{array}{llll}.06 & .50 & 2.90 & 27.00\end{array}$ $\begin{array}{llll}.07 & .60 & 4.00 & 38.00\end{array}$ $\begin{array}{llll}11 & 1.00 & 7.00 & 66.00\end{array}$ $\begin{array}{llll}.15 & 1.50 & 11.00 & 100.09\end{array}$ $.20 \quad 2.00 \quad 15.00 \quad 135.00$

$\begin{array}{llll}.25 & 2.40 & 18.50 & 170.00\end{array}$

RED BULB PANS

Size

5-inch, plain

6-inch, plain

7-inch, plain.

8-inch, plain

9-inch, plain.
10-inch, plain

\begin{tabular}{rrr} 
Each & Doz. & \multicolumn{1}{c}{100} \\
$\$ .10$ & $\$ 1.00$ & $\$ 5.75$ \\
.15 & 1.50 & 8.00 \\
.20 & 2.00 & 14.00 \\
.30 & 3.00 & 21.00 \\
.40 & 4.00 & 29.00 \\
.50 & 5.00 & 37.00
\end{tabular}

\section{EARTHEN HANGING BASKETS}

6-in. diam. at top; deep pattern, with wire. 8-in. diam. at top; deep pattern, with wire 10-in. diam. at top; deep pattern, with wire 12-in. diam. at top; deep pattern, with wire

\section{WIRE FRAME HANGING BASKETS}

Wire. With wire hanger, 8-in. plain top.

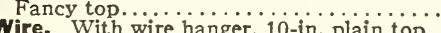

Fancy top wire hanger, 10-in. plain top.

Wire. With wire hanger, 12 in. plain top.

Fancy top.

Wire. With wire hanger, 14 in, plain top.

Fancy top.

Wire. With wire hanger, 16 -in. plain top

Fancy top.

Packing and

Each
5.50
.60
.80
1.00

15 each extra.

\section{CEMETERY VASES}

CEMETERY VASE. Metal, painted green, spike on bottom to fit in ground; holds flowers on grave nicely. Either flat bottom or pointed bottom. Each 25 c; by mail $35 c$.

\section{NEPONSET FLOWER POTS}

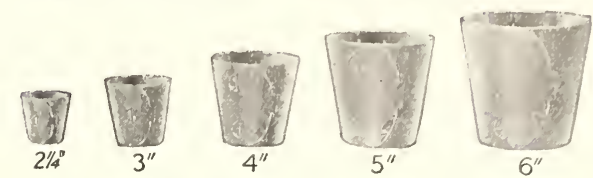

If wanted by mail, add postage at zone rates. Original crates sold at 1,000 rate.

\begin{tabular}{|c|c|c|}
\hline$\ldots \ldots$ & $\begin{array}{r}\text { Per } 12 \\
\$ .15 \\
.20 \\
.30\end{array}$ & $\begin{array}{l}100 \\
\$ .60 \\
1.00 \\
1.50 \\
2.25\end{array}$ \\
\hline
\end{tabular}

\section{"PERFECTO" SELF - WATERING FLOWER BOXES -Painted Green}

$\mathrm{M}$ a d e of coppered-steel with a lead coat then painted, which makes them lived flower boxes. Have irrigating and air-circulating system. They are perfection in window

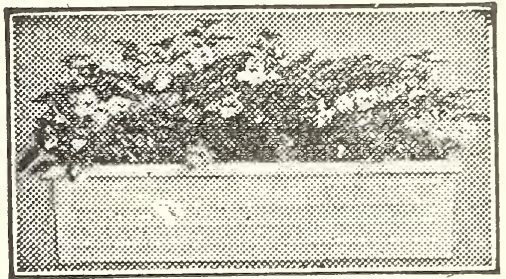

year the prices are greatly reduced. Everybody should have them. A k for descriptive circular. Ask for postage-paid prices; state size wanted.

No. 1. 6 inches ${ }^{-1 e e p, ~} 7$ inches wide, 20 inches long, 4 lbs.. $\$ \mathbf{\$ 1 . 0 0}$ No. 2. 6 inches deep, 7 inches wide, 26 inches long, 5 lbs.. $\$ \mathbf{1 . 5 0}$ No. 3. 6 inches deep, 7 inches wide, 32 inches long, 6 lbs. . $\mathbf{2 . 0 0}$ $\begin{array}{ll}\text { No. 3. } 6 \text { inches deep, } 7 \text { inches wide, } 32 \text { inches long, } 6 \text { lbs. . } & \mathbf{2} .00 \\ \text { No. 4. } 6 \text { inches deep, } 7 \text { inches wide, } 38 \text { inches long, } 7 \text { lbs.. } & \mathbf{2 . 5 0}\end{array}$ $\begin{array}{lll}\text { No. 4. } 6 \text { inches deep, } 7 \text { inches wide, } 38 \text { inches long, } 7 \text { lbs.. } & \mathbf{2 . 5 0} \\ \text { No. 5. } 6 \text { inches deep, } 7 \text { inches wide, } 44 \text { inches long, } 8 \text { lbs.. } & \mathbf{3 . 0 0}\end{array}$

\section{WINDOW BOX STANDS}

"PERFECTO" BOX STAND. If you wish to use a stand instead of placing the box on a window ledge the "Perfecto" Box Stand answers the purpose. All metal, strong, rubber tips on legs, made in green to match boxes. Attractive in living room, sunporch, or outdoor porch.

Box stand for 20-inch box, 16 lbs.

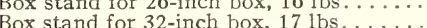

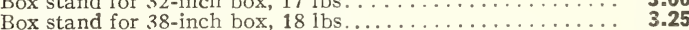

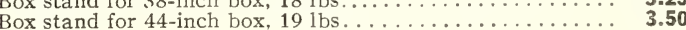

\section{WOODEN PLANT TUBS-Green}

Tubs should be shipped by express or freight.

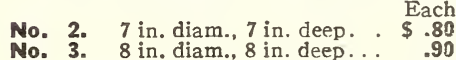

$\begin{array}{lll}\text { No. 3. } & 8 \mathrm{in} \text {. diam., } 8 \mathrm{in.} \text { deep... } & .90 \\ \text { No. 4. } 9 \mathrm{in.} \text { diam., } 9 \mathrm{in.} \text { deep... } & 1.00\end{array}$

$\begin{array}{lll}\text { No. 4. } 9 \text { in. diam., } 9 \text { in. deep... } & \mathbf{1 . 0 0} \\ \text { No. 5. } 10 \text { in. diam., } 91 / 2 \text { in. deep. } & \mathbf{1 . 2 5}\end{array}$

No. 7. 12 in. diam., 11 in. deep. $\mathbf{1 . 7 5}$

No. 9. $14 \mathrm{in}$. diam., $13 \mathrm{in.}$ deep.. 2.50

No. 11. 16 in. diam., 15 in. deep.. 3.25

No. 12. $17 \mathrm{in}$. diam., 16 in. deep... 3.75

JAPANESE TUBS. For porch plants. These are genuine Japanese. Re-coopered by us. Stained and varnished. Each $\$ 1.50$.
$\$ 1.25$.

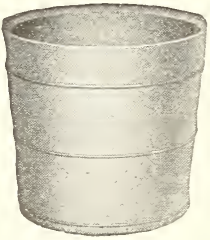

\section{MOSS}

NATURAL SHEET MOSS. For lining hanging baskets. 1/4 $\| b$. $15 \mathrm{c}$; Ib. 50c. Postage extra.

"FADELESS" SHEET MOSS, Dyed green. $1 / 4 \mathrm{lb}, 20 \mathrm{c} ; 1 / 2 \mid \mathrm{b}$. 35c: lb. 65c. Postage extra.

SPHAGNUM MOSS. Suitable for use in lining hanging baskets. 1 lb. $20 \mathrm{c}: 6$ ibs, for $\$ 1.00$. Original bales are $\$ 1.75$. 


\section{Poultry Supplies}

We carry in stock a much greater assortment than are enumerated in this catalog. If you want something in Poultry Supplies not enumerated here, please call or write us regarding what you want. A FEW OF THESE ITEMS ARE LISTED PREPAID. HOWEVER, MOST OF THE GOODS ARE F. O. B. DENVER, PURCHASER TO PAY TRANŚPORTATION.

\section{OIL-BURNING BROODERS}

\section{Have proven \\ to be the best}

SOL-HOT BLUE FLAME, WICKLESS, FIRE-PROOF METAL OIL CONTAINER

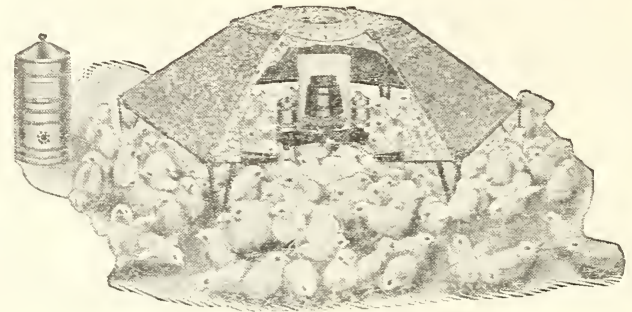

Burns coal oil, though no fumes or smoke; absolutely fiame control. Simple and easy adjustment. The new pattern is with safety screen and fuel economizer. Is very satisfactory. Requires very little attention. Twin Float Model. Delivered to your station.

24-inch Canopy. 100-chick capacity, 28 lbs.

34-inch Canopy. 300-chick capacity, 47 lbs.

44-inch Camopy. 500-chick capacity, 57 lbs

54-inch Canopy. 1,000-chick capacity, $65 \mathrm{lbs}$

17.00

$\sqrt{17.00}$

GIANT BURNER SOL-HOT BROODERS

54-inch Canopy. 1,000-chick capacity

22.50

64-inch Canopy. 1,200-chick capacity.

$\$ 24.50$

AUTOMATIC THERMOSTAT OIL CONTROL. A great oil and time-saver that can be

fitted to any of the several sizes of Sol-Hots. It takes care of the changing weather condi-

tions. Complete for $\$ 3.75$, not prepaid except with brooder shipment.

ASK FOR CIRCULAR ILLUSTRATING AND DESCRIBING THE SOL-HOT BROODERS.

\section{THERMOMETERS-AII Postpaid}

No. 5776

Tycos Incubation-Zone

Thermometer

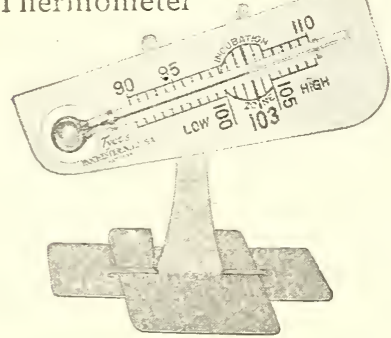

INCUBATOR, "TYCOS." Triangle, tested; on stand; complete. No. 5776 . Each 75c.

INCUBATOR, "TYCOS." "Triangle certified"

and etched on the glass tube; on stand. No.

51.15.

INCUBATOR "RELIABLE." Mounted on metal base to stand erect. Is white. Easily read. No. $800,65 \mathrm{c}$.

Flat, Red spirit. No. 57945, 65c.

cos." New pattern for use in brooder and

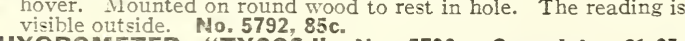
HYGROMETER, "TYCOS." No. 5795. Complete, \$1.65. WIRE for suspending Thermometers

WIRE for suspending Thermometers............... $10 \mathrm{c}$
Booklet regarding Tycos Incubator Thermomerers free.

The Patterson and Young

INCUBATOR MOISTURE GUIDE

It solves the moisture problem in incubators, by telling when to add moisture, or give ventilation. IVorks in any style incubator. The glass tube is very delicate and should be handled plete, \$1.00.

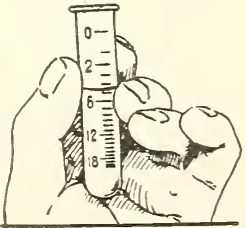

MOE'S EGG-TESTER BOX. $15 c$, postpaid. AGIC EGG-TESTER. Gives accurate test for fertility and moist ure in the egg; scientific and very reliable. $\$ 2.50$, postpaid. ( or electric globe. Powerful lens. \$1.50, postpaid.

\section{LAMPS, BURNERS}

AND EXTRAS FOR INCUBATORS AND BROODEPS Add postaze when wanted by ma:

AMP BOWLS. For No 2 Burners Galvanized.

LAMP BOWLS. For No. 3 Burners, Galyanized. $\$ .80$

LAMP BURNERS. No. 1 Bras . 35

AMP BURNERS.

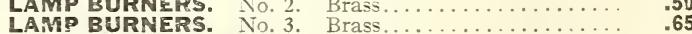

LAMP BURNERS, BRASS. Doubie ivick, Sun Hinged,

BURNER REDUCER. Fits No. 3 bowl and No. 2 burner

BURNER ENLARGER. Fits No. 2 bowl and No. 3 burne

WICKS, COMMON. For all sizes. Sfor 25 c, postpaid.

WICK'S, RED FELT. Both sizes. 6 for 25 c; postpaid.

METAL CHIMNEY. For No. 2 and No. 3 burners.

THERMOSTAT Standard Round Patern, 3 inch....

THERMOSTAT. Standard, Round Pattern, 3-inch, double

\section{LITTLE PUTNAM STOVE}

9-inch diameter, 6 inche high, galvanized iron with special oil burner heater. Keeps water from freezing. Easily handled. Galvanized. Postpaid \$1.95.

Same, made of aluminum. See illustration. Postpaid $\$ 2.50$.

W I C K S. For Putnam stoves. Per dozen $25 \mathrm{c}$.

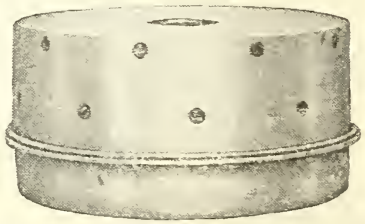

\section{PUTNAM BROODER HEATER}

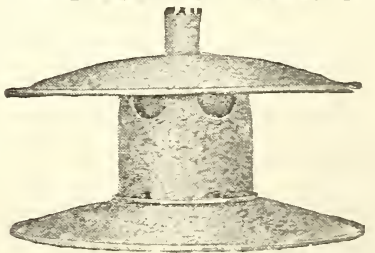

Fitted with safety oi burner. simple and safe. Directions with it to enable you to construct a homemade brooder. Heater galvanized. Postpaid \$4.75.

W I C K S. For Putnam

Heater. Per doz. 40c. ITEMS LISTED ON THIS PAGE ARE NOT POSTPAID UNLESS SO STATED. SEE PARCEL POST RATES ON PAGE 64. 


\section{FEED AND WATER DISHES}

\section{GALVANIZED}

OAKLAND IMPROVED CHICK FEEDER (McCandlish), For feed and water, a trough they cannot roost on; can be fastened to floor.

19 inches long. . $40 \mathrm{c}$

28 inches long. $60 \mathrm{c}$

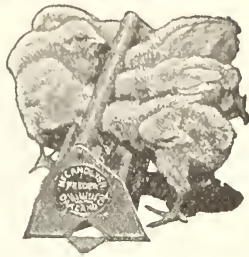

BUTTER - McCandlish Improved Tin MILK FEEDER New style for use with Powdered Buttermilk. Fitted with new s'yle hood or with roller. 32 openings, $75 c$ Buttermilk Feeders

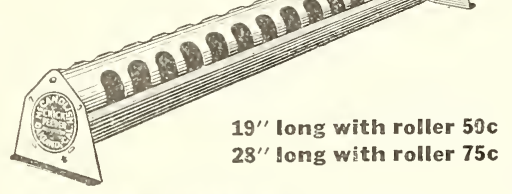

\section{COOP CUPS}

CANFIELD. No, 61. Galvanized, made very suitable for use on exhibition coops in show room. Hooks to coop bars. Each 15c
N. W. WATER FOUNTAINS

Fits onto any ordinary fruit jar. For water or milk. No. 15-5. 5" Pan. 10c each; $\$ 1.10 \mathrm{doz}$.

No. 16-6. 6" Pan. 15c each; $\$ 1.50 \mathrm{doz}$.

\section{BUCKEYE MASON JAR} FOUNTAIN

For Buttermilk or Water. 6" Earthen Pan-removable jar holder. 15c each; $\$ 1.50$ doz.

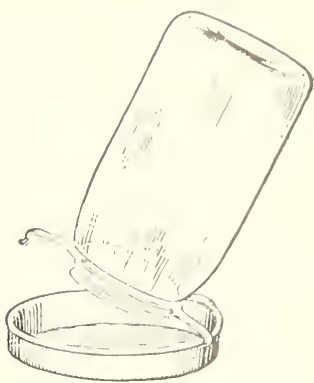

N. W. Water Fountain

\section{BERNARD'S GALVANIZED WATER FOUNTAINS}

No. 400. 5-gallon capacity, thermo style........\$5.25

No. 10. Fount, 10-gallon capacity; complete tvith lamp.. $\mathbf{6 . 5 0}$

No. 4. Fount, 5-gallon capacity; complete with lamp... 4.40

No. 3. Fount, 21/2-gallon capacity; complete with lamp. 3.40

No. 71. Leg stand or ta e stand. 1.70 F. O. B. Denver.

\section{Moe's Galvanized Poultry Goods}

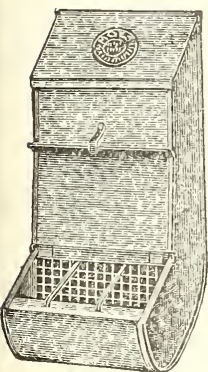

No. 35

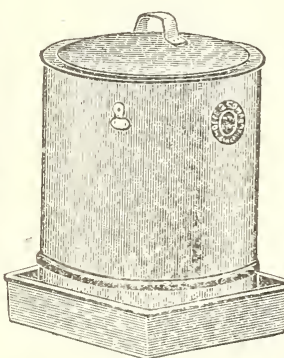

No. 2

Any Moe's Goods in dozen lots, deduct $10 \%$.

No. 35. Dry Mash Hopper, has hinged lids; 12-quart.

No. 36. Dry Mash Hopper, has hinged lids; 18-quart. .

No. 13. Dry Mash Hopper, has hinged lids; 24-quart.

No. 37. Dry Mash Hopper, has hinged lids, 36-quart.

No. 192. Peerless Feeder, adjustable up or down for all kinds of feed, and all ages. No waste of food. Capacity, 10 quarts.

No. 193. Same, with capacity of 18 quarts. .

No. 45. Grit and Shell Box, 2 compartments, flat bottom

No. 9. Grit and Shell Box, 3 compartments, round bot-

No. 90. Grit and Shell Box, 4 compartments, round bot-

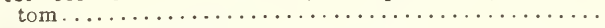
Nc. 460. Chick Feed Trough, $18^{\prime \prime}$ long. No, 462. Chick Feed Trough, $30^{\prime \prime}$ long.

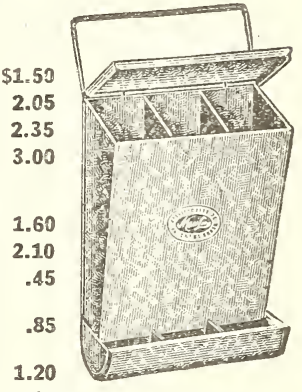

No. 9
No. 11. Baby Chick Feeders, with 8 holes

$\$ .12$

.25

.20

.35

.35

.30

No. 58. Double Feeding Troughs, for chicks; 12 inches long.

No. 59. Double Feeding Troughs, for chicks; 18 inches

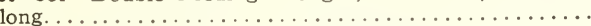

No. 44. Vegetable Rock. Prevents waste.

No. $137 . \quad$ Buttermilk Feeder, 10-hole size.

No, 139. Buttermilk Feeder, 20-hole size.

No. 152, Buttermilk Fount. Bottom Fill. .

No. 69. Eclipse, aluminum, for buttermilk, sliding top,

10 -inch......

No. 18. Magazine Chick Feeder, adjustable for feed or water; 2-quart.

No. 139. The same magazine feeder style, made of tinplate, for buttermilk.

No. 140. Large Capacity Feeder, time and labor-saver; holds 10 quarts feed; 21 inches..................

No. 141. Large capacity Feeder, 17-quart size.........

No. 40. Drop Bottom Wall Fount, easily cleaned; 2-quart

No. 41. Drop Bottom Wall Fount; 1-gallon......... 1.15

No. 42. Drop Bottom Wall Fount; 2-gallon........... 1.50

No. 97. Improved Wall Fount; $1 / 2$ gallon. . . . . . . . . . .90

No. 98. Improved Wall Fount; solid; 1-gallon......... 1.15

No. 26. Wall Fountain, removable bottom; 1-gallon..... . .70
No. 14. Flat Top Fount; 1-quart.

No. 15. Flat Top Fount; 2-quart.

No. 16. Flat Top Fount; 1-gallon.

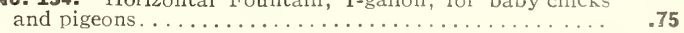

No. 135. Horizontal Fountain; 2-gallon; for baby chicks

No. 2. Top Fill Fount, telescopes, seldom freezes; 2-gal. 2.60

No. 33. Top Fill Fount. . 2-gallon canacity; round base.. 2.60

No. 34. Top Fill Fount. 4-gallon capacity; round base. 3.10

No. 10. Cold Climate Heater, with lamp complete; works well with Top Fill Founts; heater alone

2.03

\section{MOE'S $\star$ STAR FOUNTAIN AND FEEDER NO. 32}

Made of a single piece of heavy metal. No solder, no seams, no loose parts. Suitable for feed as well as water. Suitable ror feed as well as water. Little chicks cannot drown. Fits any Each 10c.

No. 133. Star, made of aluminum, for buttermilk. Each 10c.

No. 142. Moe's Mason Jar Holder. Each 10c.

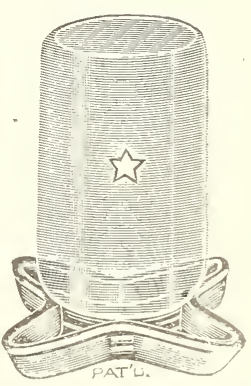




\section{EARTHENWARE DISHES \\ FOR RABBITS AND CAVIES.}

Should not be mailed.

RABBIT DRINK DISHES. Plain, round bottom inside, seldom break by freezing. 1-pt. size, each 15c; 12 for $\$ 1.50$. 1 -qt. size, each $18 \mathrm{c}$; 12 for $\$ 1.80$.

FLANGE TOP RABBIT FEED DISHES, 1-pt. size, each 18c; 12 for \$2.00. 1-qt., a very popular size, each 20 c; 12 for $\$ 2.25$.

POULTRY JUG FOUNT

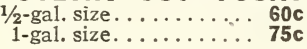

TWO-PIECE EARTHEN DRINKING FOUNT. 1gal. size 75c; 2-gal. size $\$ 1.25$.

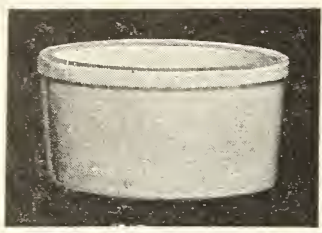

\section{ROOFING-MICA COATED}

For poultry houses and sheds

1-ply Elaterite, "Buffalo." Per roll of 108 sq. ft., with nails, etc., $\$ 2.00$. 2-ply Elaterite, "Buffalo." Per roll of 108 sq. $\mathrm{ft}$., with nails, etc.,
\$2.50.

3-ply Elaterite, "Buffalo." Per roll of 108 sq. ft., with nails, etc.

\section{POULTRY AND RABBIT NETTING}

POULTRY NETTING. U. S. Standard, 2-inch mesh, No. 20 wire. The kind that does not sag.

30 in. high, cut to order, per running foot.

$3 \mathrm{ft}$. high, cut to order, per running $\mathrm{ft}$.

$4 \mathrm{ft}$. high, cut to order, per running $\mathrm{ft}$.

$5 \mathrm{ft}$. high, cut to order, per running $\mathrm{ft}$.

$6 \mathrm{ft}$. high, cut to order, per running $\mathrm{ft}$.

Original rolls of $150 \mathrm{ft}$. long, $1 / 2 \mathrm{c}$ less per $\mathrm{ft}$.

RABBIT NETTING. American. 1-inch mesh, No. 20 wire. 12 inches high, cut to order, per running $\mathrm{ft}$.

18 inches high, cut to order, per running $\mathrm{ft}$.

24 inches high, cut to order, per running $\mathrm{ft}$.

30 inches high, cut to order, per running ft.

36 inches high, cut to order, per running ft.

Original rolls of $150 \mathrm{ft}$. long, $1 / 2 \mathrm{C}$ less per $\mathrm{ft}$.
SCREEN-GLASS (VIO-RAY)

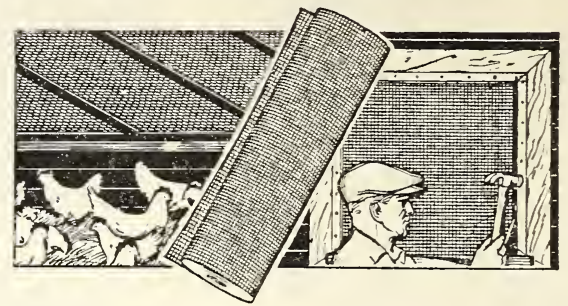

A new process glass that transmits sun's violet rays, is flexible and practically unbreakable, for scratch sheds, etc. Is prepared on fine wire cloth 36 inches wide. (Ask for small sample with circular). Original roll of 25 lineal feet for $\$ 9.75 ; 50$ lineal feet for $\$ 19.00 ; 100$ lineal feet for $\$ 37.50$. Less than above rolls cut to order $42 \mathrm{c}$ per lineal foot.

\section{GLASS CLOTH}

\section{"Lets the Violet Rays through"}

Is waterproof and weatherproof, d u rable and cheaper $t$ ha $n$ glass. Fine for chicken houses, garages, $\mathrm{b}$ a c $\mathrm{k}$ porches, etc. Comes in rolls 36 inches wide.

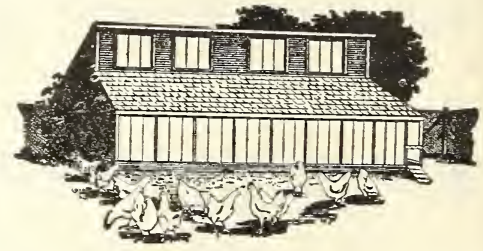

15-yard roll trial lot (postpaid)

25 -yard roll (not postpaid)

50-yard roll (not postpaid)

100 -yard roll (not postpaid)

Cut to order (not postpaid), per yard

$\$ 5.00$

6.90

13.75

27.50

\section{LIMBER GLASS}

A lighter grade of Glass Cloth. 30 inches wide. 50 -yard roll

Cut to order, per yard

36 inches wide.

50 -yard roll

Cut to order, per yard

Not Postpaid. Samples and leaflets free on request.
$\$ 12.00$

$\$ 13.00$

\section{Our Poultry Food Mixtures}

These Items are favored by prominent poultry raisers; you can safely depend upon them for resu:ts.

\section{In addition we have a full line of Pratt's.}

All our Poultry Food Mixtures are made in accordance with Colorado State Feed Laws. The prices are constantly changing. For latest prices in quantity lots ask for latest "Special Price List." All prices Net, f. 0. b. Denver, Subject to market price. MEN FEED. Hen Scratch.

5-lb. bag, 25c; 10-lb. bag, 4Cc; 25-lb. bag, 70c; 50-lb. bag, $\$ 1.25 ; 100-1 b$. bag, $\$ 2.35$

SCRATCH FEED FOR GROWING CHICKS. Coarser than starter for feeding after eight to ten weeks old.

$5-\mathrm{lb}$. bag, $25 \mathrm{c} ; 10-\mathrm{lb}$. bag, 45c; $25-\mathrm{lb}$. bag, 90c; 50-lb. bag, $\$ 1.60 ; 100-\mathrm{lb}$. bag, $\$ 2.90$.

EGG MAKER OR LAYING MASH. Feed dry or as a wet mash. 5-lb. bag, $25 \mathrm{c} ; 10-\mathrm{lb}$. bag, 45c; 25-1b. bag, 90c; $50-1 \mathrm{~b}$. bag, $\$ 1.60 ; 100-\mathrm{lb}$. bag, $\$ 3.00$.

CHICK GROWING MASH.

5-lb. bag, 30c; 10-lb. bag, 55c; 25-lb. bag, \$1.10; 50-lb. bag, $\$ 1.90 ; 100-\mathrm{lb}$. bag, $\$ 3.50$.

Special Feeds For Baby Chicks, see page 57.

\section{PACKING HOUSE POULTRY FOODS}

GREEN CUT BONE. Dried and granulated, hen and chick size mix with other foods. 5 lbs. 25c; $11 \mathrm{lbs}$. 50c; 24 lbs. $\$ 1.00$ FINE BONE. For chicks; should be given in soft food; first grade, clean. 5 lbs. 25c; 11 lbs. 50c; 24 lbs. $\$ 1.00$.

BLOOD MEAL. Carries 80 per cent protein; for feeding mash

a true "Red Albumen." 1 lb. 10c; 3 Ibs. 25c; 7 lbs. 50c; 15 lbs.

1.00. Cannot be mailed.
MEAT SCRAPS. High protein. Highly concentrated food, running 60 per cent protein; excellent in a mash. 3 lbs. 25c 7 lbs. 50c; 16 lbs. $\$ 1.00$.

Prices for 50 -1b. and 100-1b. sacks. All Poultry Foods depend on market. Ask for latest "Special Price L ist."

\section{MISCELLANEOUS POULTRY FOODS}

PRICES SUBJECT TO CHANGE.

CRUSHED OYSTER SHELL. Necessary to every fowl. Regular size. $31 / 2$ lbs. 10c: 10 Ibs. 25c; 25 lbs. 50c; 50 lbs. $85 \mathrm{c}$; 100 lb. sack $\$ 1.25$.

"CRYSCO"GRIT. White. Contains somelime. 10 lbs. 25e; $25 \mathrm{lbs}$. $50 \mathrm{c}$; $50 \mathrm{lbs}$. $85 \mathrm{c}$; 100 -lb. sack $\$ 1.25$.

CHARCOAL. Hen and chick size. 1 lb. 10c; 3 lbs. 25c; 7 lbs. 50c: $50-1 b$. bag $\$ 1.50 ; 100$ lbs. $\$ 2.75$.

GROUND OIL CAKE. Fine. 4 lbs. 25c; 9 lbs. 50c; 20 lbs. $\$ 1.00=100=16$. bag $\$ 4.00$.

C1.00; 100-lb. bag 54.00. 50 c: 24 lbs. $\$ 1.00$. 100 Ibs. $\$ 3.50$.

FLAXSEED MEAL. Pure ground flaxseed. $1 \mathrm{lb}$. 15c; 2 lbs. 25 c: $41 / 2$ lbs. 50 c: 10 lbs. $\$ 1.00$.

POULTRY PEPPER, Ground. $1 \mathrm{lb} .20 \mathrm{c} ; 5$ lbs. 80c; 25 lbs. $\$ 3.50$.

YEAST, NORTHWESTERN. For poultry. 4-Ib. can $\$ 1.00$ by mail 51.25 : 25-lb. box f. o b. Denver $\$ 6.00$.

DRIED POWDERED BUTTERMILK. 33 per cent protein.

$1 \mathrm{lb} .20 \mathrm{c} ; 9 \mathrm{lbs}$. $\$ 1.00 ; 50 \mathrm{lbs}$. $\$ 4.50 ; 100-1 \mathrm{~b}$. sack $\$ 8.50$.

For Rabbit and Pigeon feeds and supplies refer to page 57. 


\section{Poultry Remedies and Tonics}

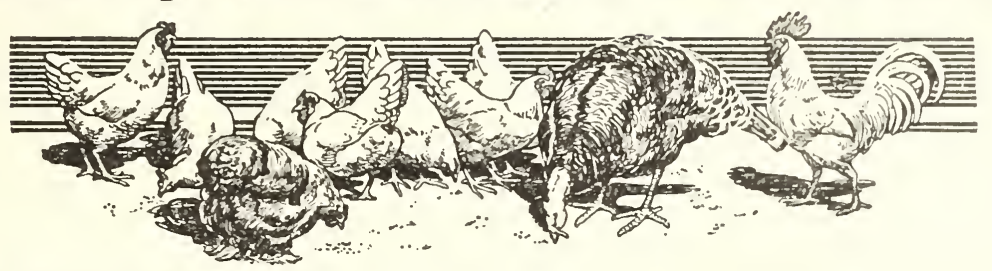

\section{POULTRY REMEDIES}

\section{NOT POSTPAID UNLESS SO STATED.}

PRATT'S R-P ROUP REMEDY. Powder and tablets, either. 30c, 60c and \$1.20. Postpaid. PETS. 30c and 60c. Postpaid.

PRATT'S CONDITION TABLETS. 60c. Postpaid.

paid.'S WORM POWDER. Pkg. 60c and

\$1.20. 12-lb. bag, not prepaid, \$2.20; 25-lb.

PRATT'S N-K TABLETS FOR WORMS. Adult size. Pkg. of 50 tablets $\$ 1.00$; Pkg. of 100 tablets $\$ 1.75$; Chick size. Pkg. of 50 tablets $65 \mathrm{c}$; 100 tablets $\$ 1.00$.

CONKEY'S POULTRY LAXATIVE. $30 \mathrm{c}$ and

$60 \mathrm{c}$. Postpaid.

CONKEY'S ROUP PILLS. \$1.20. Postpaid.

CONKEY'S POX SOREHEAD REMEDY. 30c and 60c.

CONKEY'S LIMBERNECK REMEDY. Per pKg. 60c.

CONKEY'S GAPE REMEDY. 30c and 60c. Postpaid.

BARNES' WORM EMULSION. A liquid preparation for us in killing all kinds of worms in poultry. It also is a health tonic. can $\$ 1.00$; gallon can $\$ 3.00 ; 5$-gallon $\mathrm{keg} \$ 12.50$.

"AVICOL." For white diarrhoea and cholera. Pkt. 50c and \$1.00. Postpaid.

EMPIRE ANTI-GERM ROUP REMEDY. Powder. 30c. Post-

paid.
LEE'S FLU-KOFF. For roup, colds, etc. 12-oz. size $\$ 1.00$; LEE'S FLU-KOFF, For roup, colds, etc. $12-0 z$. size $\$ 1.00$; LEE'S “"GERMOZONE." Liquid; can't be mailed. 4 oz. bottle $40 \mathrm{c} ; 12-0 z$. 75c; 32-oz. $\$ 1.50$; gal. $\$ 4.50$.

LEE'S "GERMOZONE." Tablet form. Each 25c; 75c and \$1.50. Postpaid.

RUBBER SYRINGE to use with liquid remedies 25c. Postpaid. LEE'S VAPO-SPRAY. For colds, roup, etc. $1 / 2$ gallon $\$ 1.25$; gallon $\$ 2.00$. Not prepaid.

LEE'S GIZZARD CAPSULES. 50 capsules 51.00 ; 100 capsules $\$ 1.75$. Chick size. 50 capsules $50 \mathrm{c} ; 100$ capsules $90 \mathrm{c}$. Sulles \$1.75. Ahick size. 50 capsules 50 c; 100 capsules 90 c.
ocULEUM. An innoculation for Roup and White Diarrhoea. 50c and \$1.00. Postpaid.

"POULTOBAC." Specially prepared tobacco powder that is highly recommended for use in destroying Round Worms in poultry. Ask for literature that tells how to rid your forls of this dangerous condition. 2-lb. sealed can $35 \mathrm{c} ; 10-\mathrm{lb}$. sealed bag, $\$ 1.00 ; 25-\mathrm{lb}$. seaied bag $\$ 2.00$. Not postpaid.

GROUP-OVER. For colds in poultry, 50c and 51.00 . Postpaid. WALKO TABLETS. For white diarrhoea, cholera and roup. $50 \mathrm{c}$ and $\$ 1.00$ sizes. Postpaid.

\section{EGG FOODS AND TONICS}

Not postpaid unless notated otherwise. PRATT'S POULTRY RE GULATOR. 26oz. pkg. 30c; 4-lb. pkg. 60c; 12-lb. pkg. \$1.75; 25-lb. sack $\$ 3.00 ; 100-\mathrm{lb}$. sack $\$ 10.50$.

EMPIRE POULTRY CONDITIONER. "Made in Colorado." Regular size 30c; large size $60 \mathrm{c}$

DR. HESS' POULTRY PANAMIN. 3-Ib. pkg. 65c; 7-lb. pkg. \$1.25; 25-lb. pail $\$ 3.50 ; 100-1 b$. drum $\$ 12.00$.

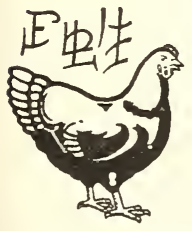

LEE'S EGG MAKER. Concentrated. Per 2-Ib. pkg. 40c; 5-Ib. pkg. 90c; 12-Ib. pail $\$ 2.00$; 25 -Ib. pail $\$ 3.75$.

DON SUNG. A concentrated tonic in tablet form; should be used through winter months. extra large size pkg. $\$ 5.00$. All postpaid.

\section{POULTRY LITTER (Imported Peat)}

Is economical, sanitary and prevents dampness. Ideal for the brooder houses.

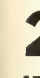

BUSHEL BALE

(Compressed)

$\$ 4.25$ bag, not prepaid, $\$ 3.85$.

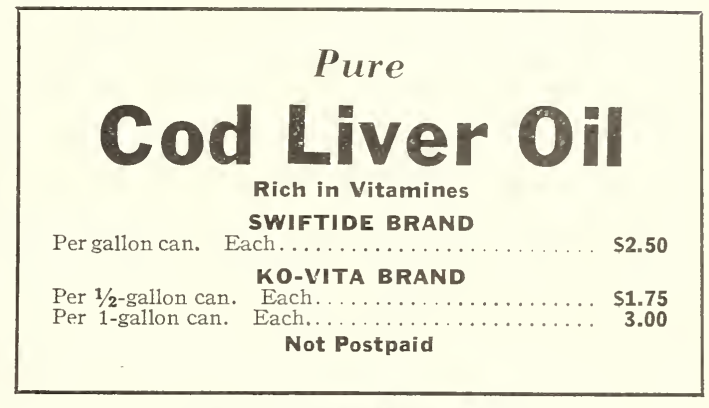

\section{LICE KILLERS}

These Goods are Not Postpaid.

CONKEY'S LIQUID. 2 qts. 90c; gallon $\$ 1.50$.

CONKEY'S HEAD LICE OINTMENT. 21/20Zs. 30c; postpaid. PRATT'S LICE KILLER POWDER. $1 \mathrm{lb}$. 30c; 21/2-Ib. pkg. $60 \mathrm{c}$.

PRATT'S RED MITE SPECIAL. Liquid. Qt. 70c; 2 qts. $\$ 1.15 ; 1$-gal. can $\$ 2.00$.

PRATT'S HEAD LICE OINTMENT. 30c. Postpaid.

CREOSOTE. Qt. can $40 \mathrm{c}$; $1 / 2$ gal. $50 \mathrm{c}$; gal. can $75 \mathrm{c}$.

LEE'S LOUSE POWDER. With sifter top. 1-lb. can 25c.

LEE'S LICE KILLER (Liquid), Qt. 60c; 2 qts. 90c; gal. can $\$ 1.50$.

PERSIAN INSECT POWDER. Pure. $1 \mathrm{oz} .10 \mathrm{c} ; 1 / 4 \mathrm{lb} .25 \mathrm{c}$; $1 / 2 \mathrm{lb} .45 \mathrm{c}$; Ib. $80 \mathrm{c}$.

"LICENE." A paste in tube. Each (postpaid) 60c.

SODIUM FLUORIDE. One of the best powders. 1/4-ib. can 15c; $1 / 2-1 b$. can $25 c$; $1-l b$. can $45 c$. Postpaid. 5-lb. bulk \$1.25. Not prepaid.

TOBACCO DUST. Helps to keep down lice. 1 lb. 15c; 2 lbs. $25 \mathrm{c}$; 5 Ibs. 50c; io Ibs. 90c; 25 Ibs. 52.00.

"BLACK LEAF 40." A very effective liquid for use on perches and walls. 1-oz. bottle $35 \mathrm{c} ; 1 / 2-1 \mathrm{~b}$. bottle $51.25 ; 2-\mathrm{lb}$. can $\$ 3.25 ; 10-$ ib. can $\$ 11.85$. Cannot be mailed.

\section{POULTRY HOUSE DISINFECTANTS}

FUMIGATING CANDLES. Sulphur in cake form to burn. Each 15c. By mail 20c.

LIME. For whitewashing poultry house. 2 Ibs. 10c; 6 Ibs. 25c; $10-\mathrm{lb}$. bag $40 \mathrm{c} ; 50 \mathrm{lbs}$. $\$ 1.00 ; 200 \mathrm{lbs}$. $\$ 3.50$.

PRATT'S POULTRY DISINFECTANT. Pt. $45 \mathrm{c}$; qt. $7 \mathrm{c}$; 2 qts. $\$ 1.20$; gallon $\$ 2.00$.

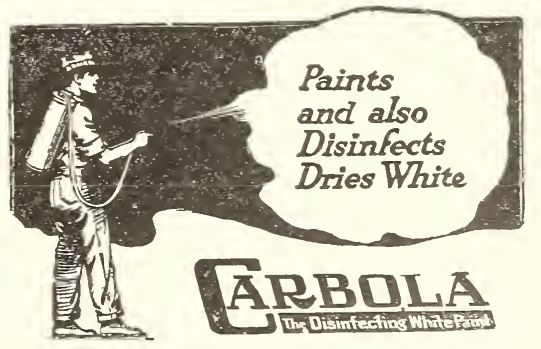

A white paint and powerful disinfectant in powder form. Quickly mixed with water-no waiting or straining. Applied with brush or sprayer to all surfaces.

5-Ib. pkg. 75c; 10-lb. pkg. (makes 10 gallons) $\$ 1.25 ; 50-I b$. sack $\$ 5.00$.

When applying as a whitewash, use sprayer Bucket Pump. We recommend the Hudson "Modoc" No. 122, all complete, for $\$ 4.25$, as described on page 46 .

ITEMS LISTED ON THIS PAGE ARE NOT POSTPAID UNLESS SO STATED; SEE PARCEL POST RATES ON PAGE 64, 


\section{Miscellaneous Requisites}

\section{LEG BANDS-All Postpaid}

RELIABLE, ADJUSTABLE, COLORED. Five colors, aluminum with celluloid. Large colored figures. Will fit any size leg. viry desirable. 12 for $35 \mathrm{c}$; 25 for $60 \mathrm{c} ; 50$ for $\$ 1.00 ; 100$ for $\$ 1.90$.

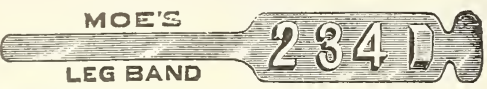

MOE'S IMPROVED CHAMPION. ALUminum, flat fi any bird, raised numbers. 12 for $15 c$; box of 25 for $25 \mathrm{c} ; 50$ for $40 \mathrm{c}$; 100 for $65 \mathrm{C} ; 500$ for $\$ 2.50 ; 1,000$ for $\$ 4.25$.

"SPIRALET" OR KEY RING CELLULOID LEG BANDS. In popular colors, red, blue, green, yellow.

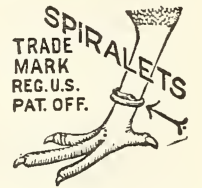

$\begin{array}{llllll}\text { Per } 12 & 25 & 50 & 100 & 500 & 1.000\end{array}$

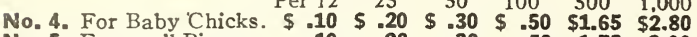

$\begin{array}{llllllll}\text { No. 5. For small Pigeons. } & .10 & .20 & .30 & .50 & \mathbf{1 . 7 5} & \mathbf{3} & \mathbf{3} .00\end{array}$

$\begin{array}{lllllll}\text { No. 6. For large Pigeons. } & .10 & .20 & .35 & .55 & 2.00 & 3.50\end{array}$

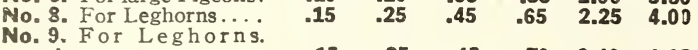

males.

$\begin{array}{llllll}.15 & .25 & .45 & .70 & 2.40 & 4.25\end{array}$

No. 11. For American

$\begin{array}{lllllll}\text { breeds... } & 15 & .25 & .45 & .70 & 2.50 & 4.50\end{array}$

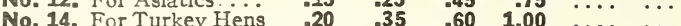

BANDETTE-Double Numbered. Heavy celluloid. In several

Nolors. 6. Pigeon size. 25 for $50 \mathrm{c} ; 100$ for $\$ 1.50$

No. 7. Bantam size. 25 for $50 \mathrm{c}$ : 100 for $\$ 1.50$.

No. 9. Leghorn size. 25 for $60 \mathrm{c} ; 100$ for $\$ 1.80$.

No. 11. American size. 25 for $65 \mathrm{c} ; 100$ for $\$ 2.00$.

Po. 12. Asiatic size. 25 for $65 \mathrm{c} ; 100$ for $\$ 2.00$.

VICTOR. Wide aluminum. Large colored figures, best for show room; figures will not come off; 25 in box. Less box, $5 c$ each 25 for $\$ 1.00 ; 50$ for $\$ 1.85 ; 100$ for $\$ 3.50$.

LEG BAND CLIPS. Clamp onto the band, numbered, 12 for 10 c; 50 for 35 c; 100 for 60 c.

\section{PIGEON BANDS}

Colored, double numbered; red, blue, green, yellow. 12 pairs for $50 \mathrm{c} ; 25$ pairs for $\$ 1.00 ; 100$ pairs for $\$ 3.50$.

\section{TURKEY BELLS}

Every turkey breeder needs a Turkey bell for the toms; open bell. each $25 \mathrm{c}$; closed or round bell, each $20 \mathrm{c}$.

\section{CHICKEN MARKERS All Postpaid}

PERFECT POULTRY PUNCH. Small hole. Each 15c.

PETTY'S LEVER POULTRY PUNCH. $35 \mathrm{c}$.
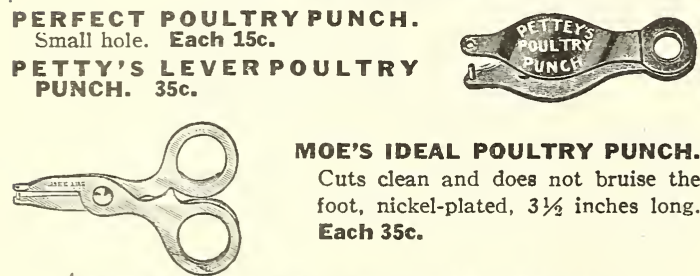

MOE'S IDEAL POULTRY PUNCH.

Cuts clean and does not bruise the foot, nickel-plated, $3 \frac{1}{2}$ inches long. Each 35c.

\section{CAPONIZING INSTRUMENTS}

\section{ALL POSTPAID}

PHILADELPHIA. A complete set in plain box.........\$3.00 PILLING'S FARMERS' SET. With full directions, neat case. simpicici King's Book, "CAPONS FOR MONEY," value \$i.00: free with above set. Separate. ...................

\section{KILLING KNIVES}

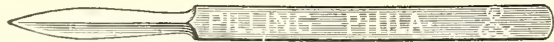

FRENCH PATTERN. As above illustration. Postpaid, 60c.

SAFE-EDGE PATTERN. Same as French pattern, except cuts on one side only. Postpaid, 60c.

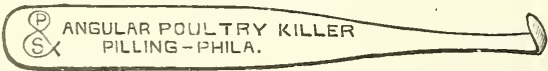

PILLING'S ANGULAR POULTRY KILLING KNIFE. Postpaid, $50 \mathrm{c}$.

ITEMS LISTED ON THIS PAGE ARE NOT POSTPAID UNLESS SO STATED. SEE PARCEL POST RATES ON PAGE 64.

Coppered wire; lasts a lifetime. Fastens to wall; 13 to 14 inch diameter. Dozen $\$ 3.25$; each 30 c. Not postpaid.

\section{NEST EGGS}

PORCELAIN. Best imitation of eggs. 3 for $10 \mathrm{c}$; 12 for 35c. IMED. Hard, for use in nest. 3 for $10 c ; 12$ for $35 c$

Nest Eggs by mail, 1c each extra.

\section{METAL EGG CRATES}

Indestructible; pays for itself in a few shipments; lasts for years: makes interchangeable shipping 'easy. Light in weight but strong. SIZES AND PRICES $11 / 2$-doz. size, weight, empty, 3 lbs.; filled, 5 lbs.. . . . . \$1.25 2-doz. size, weight, empty, 4 lbs.; filled, 6 lbs.

3-doz. size, weight, empty, 4 lbs.; filled, 8 lbs.. . . . . . 4-doz. size, weight, empty, 5 lbs.; filled, 11 lbs....... 6-doz. size, weight, empty, 6 lbs.; filled, 15 lbs... ...
12-doz. size, weight, empty,

10 lbs.; filled, $28 \mathrm{lbs}$. . . 4.00

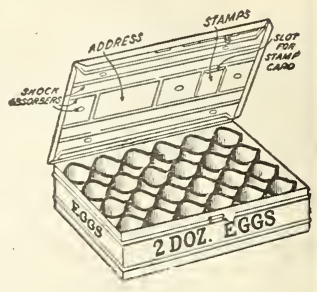
at zone rates. Ask for descriptive circular.

\section{EGG CARTONS}

STANDARD STYLE. $3 \times 4$, holds 12 eggs, folds, 12 for $20 \mathrm{c} ; 25$ tor $35 \mathrm{c} ; 125$ for $\$ 1.25 ; 250$ coriginal bale) for $\$ 2.15 ; 1,000$ for $\$ 8.00$. Postage on Cartons by mail extra. 12 weigh $11 / 4 \mathrm{lb}$.
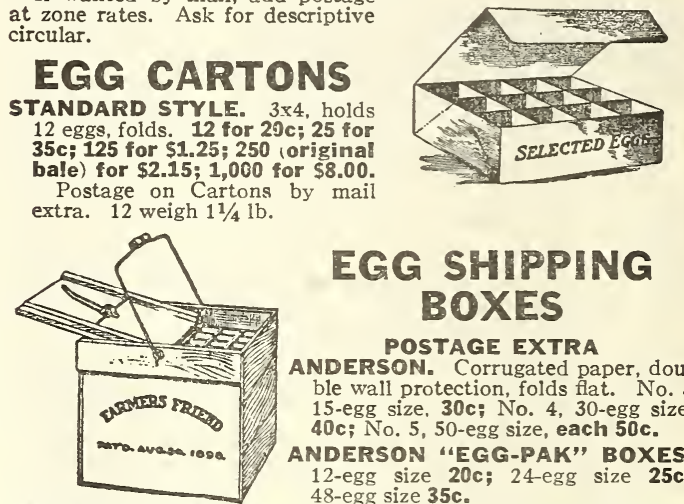

\section{EGG SHIPPING BOXES}

POSTAGE EXTRA

ANDERSON. Corrugated paper, dou

ble wall protection, folds flat. No. 3 15-egg size, 30c; No. 4, 30-egg size, $40 \mathrm{c}$; No. 5, 50-egg size, each $50 \mathrm{c}$. NDERSON "EGG-PAK" BOXES. 12-egg size 20c; 24-egg size 25c; FARMERS' FRIEND EGG CARRIER. Woode case, painted, clamp lock cover, with fille-s. 12-doz. size, each \$1.15; 6-doz. size, suitable for automobile $81 / 2 \times 121 / 2, \$ 1.10$.

\section{EGG}

PRESERVERS DIRECTIONS ON EACH PACKAGE

WATER GLASS (Liquid) Pint (enough for 12 dozen) 25c; Quart 40c; $1 / 2-g a l$ 70c. Not postpaid

FLEMING'S EGG KEEP (Paste). Easy to apply. $2-\mathrm{oz}$. can $(60$ to 90 doz. eggs) $\$ 1.00$; $4-0 z$, can (120 to 180 doz. eggs) $\$ 1.50$. postpaid.

EE'S EGG O'LATUM (Paste). 2-oz. jar (50 doz. eggs) 50c; 8-oz jat (200 doz. eggs) \$1.00; postpaid.

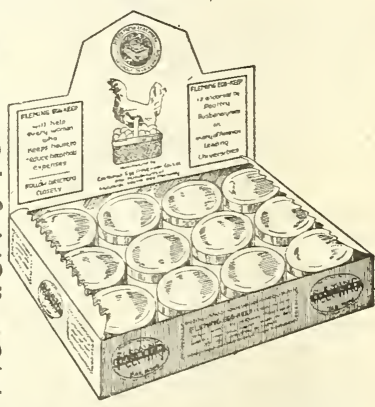

\section{EXHIBITION COOPS}

Shipped folded, all ready to fasten together. WOOD, WITH CANVAS. Racine, $24 \times 24 \times 30$. $\$ 3.75$

\section{LITTLE CHICK BROODING-YARD}

Galvanized material. Suitable for yard use. Made of wire, as \$1.45.

\section{RACINE SHIPPING COOPS}

All wood. Slatted tops insure safety in transit. Furnished complete, material knocked down, ready to set up by nailing corners.

Size "B." $18 \times 21 \times 21$ f for pair or small trio............ Each

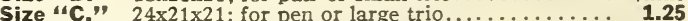
1.50 PRICES ARE NET F. O. B. DENVER 


\title{
BABY CHICKS
}

Purchasing "day-old chicks" is now the popular, surest and cheapest way to get young stock.

A chick is a chick, while an egg is a chance.

We have arranged with a popular hatcher whereby we can supply promptly the leading breeds of "Day-OId Chicks." This stock is from truly selected stock-the kind that is bred to lay. Strictly No. 1 .

They are shipped in light, ventilated, non-crowding boxes, pnstpaid, and guardntee safe delivery. If you will mention your second choice, in case we are short on kind you ordered, it will save time.

Can usually ship on Tuesdays and Fridays, beginning about January 27. Please anticipate your wants in advance at least six days and kindly remit with your order.

You will note that we can ship in lots of 100 at a great saving for you. The cost of postage, container and special packing is nearly as much on 25 or 50 as 100 . Per 25 Per 50 Per 100

C. White Leghorns

S. C. Brown Leghorns. Chicks Chicks Chicks

Barred Rocks.

Buff Rocks.

R. I. Reds.

White Rocks.

White Wyandottes.

Buff Orpingtons.

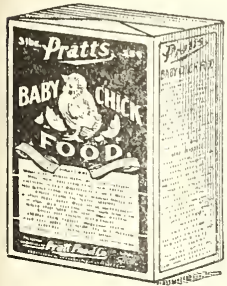

$\$ 4.00 \quad \$ 7.00 \quad \$ 13.00$

We pay postage on these Day-Oid

$\begin{array}{lll}4.50 & 8.00 \quad 15.00\end{array}$
Chicks. by mail.

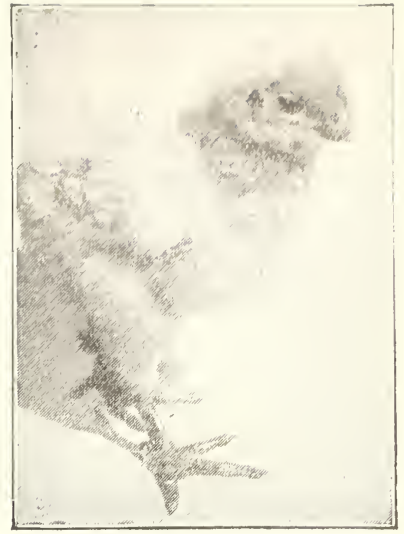

\section{SPECIAL FEEDS FOR BABY CHICKS}

\author{
PRICES ARE NET F. O. B. DENVER
}

We heartily recommend the following feeds for young chicks.

When wanting for chicks 8 to 10 months old, see our assortment on page 54

CHICK-STARTER SCRATCH FEED. Can feed at once to young chicks. 5-lb. bag $25 \mathrm{c}$ : $10-1 \mathrm{~b}$. bag 45c; 25-1/b. bag 95c; 50-lb. bag $\$ 1.65$; $100-1 \mathrm{~b}$. bag $\$ 3.1$.

CHICK GROWING MASH FOR BABY CHICKS. Should be the first feed. 5-1b. bag 30c: 10-1b. bag $55 \mathrm{c} ; 25-1 \mathrm{~b}$. bag $\$ 1.10$; $50-\mathrm{lb}$. bag $\$ 1.90$; 100-16. bag $\$ 3.50$.

\section{RABBIT AND FOX SUPPLIES}

\section{SULPHURIZED SALT SPOOLS}

Each spool has hole for nail to fasten to wall. Made from the purest kiln-dried evaporated salt, not a dope. The sulphurized spool has sulphur added to pure salt. The health-giving quality of sulphur is well known, making the sulphurized spool the best health-giving. Each $5 \mathrm{c} ; 12$ for $55 \mathrm{c}$; 12 by mail for $70 \mathrm{c}$; 100 not prepaid for $\$ 4.00$.

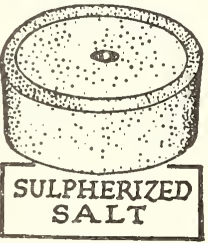

MINERAL SALT SPOOLS. The mineral spool has mineral salt added to the sulphurized spool. It contains the 12 salts of the earth. There is nothing better for a conditioner for all kinds stock. Each $10 \mathrm{c} ; 3$ for $25 \mathrm{c}$; 12 sor $85 \mathrm{c} ; 12$ by mail for $\$ 1.00$. 100 for $\$ 5.00$; not postpaid.

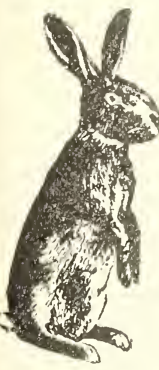

BOVIER'S RABBIT REMEDY. Remedy for snuffles. 16-oz. can 70c. By maill 80c; 7-0z. can 35c. By mail $40 \mathrm{c}$.

HUTCH SCRAPER. Galvanized; No. 47 very useful. Each 20c. By mail 25c.

LONG HANDLE HUTCM SCRAPER, No. 51. 30-inch long handle. 50c. By maill 60c. VEGETABLE AND ALFALFA RACK, No. 44. $13 \times 81 / 2$ inches. Fastens to wall. $90 \mathrm{C}$ By mail $\$ 1.00$.

ROUND EARTHEN DISHES. See "Earthenware Dishes," page 54.

RABBIT EAR TATTOD MARKER. Outfit complete $\$ 1.00$, postpaid. Tattoo Ink $40 \mathrm{C}$ postpaid. For books on Rabbits, see below. IRON YARD ORNAMENT RABBIT.
RAN White with pink eyes. $\$ 1.85$.
PRATT'S BUTTERMILK BABY-CHICK FOOD. A pre-digested food for youngest chicks; full directions on each package. 21/2-lb. pkg. 25c; $5-1 b$. bag 35c; $10-1 \mathrm{~b}$. sack 65c; $25-\mathrm{bb}$. sack $\$ 1.55$ $50-1 \mathrm{~b}$. sack $\$ 2.85 ; 100-\mathrm{lb}$. sack $\$ 5.40 ; 5$ sacks at $\$ 5.00$ per sack.

PRATT'S BUTTERMILK GROVING-MASH. $10-1 b$. sack 55c; $25-1 b$. sack $\$ 1.35 ; 50-i b$. sack $\$ 2.40 ; 100-i b$. sack $\$ 4.60$.

\section{PIGEON SUPPLIES}

PIGEON FEEDS ARE NOT POSTPAID

"DEPENDABLE" MIXED PIGEON FEED. Our own formula. 5 lbs. 25c; 11 lbs. 50c; 25 lbs. \$1.00; 50 lbs. $\$ 1.80 ; 100$ lbs. $\$ 3.25$.

SMALL DRY PEAS. 3 ths, 25c; 7 lbs. 50c; 16 lbs, $\$ 1.00$. WHITE KAFIR CORN. Select seed. 7 lbs. 25c; 15 lbs. 50c; 33 Ibs. $\$ 1.00$ : 100-lb. bag $\$ 2.50$.

BUCKWHEAT. Recleaned. 3 lbs. 25c; 7 lbs. $50 \mathrm{c} ; 16$ Ibs. \$1,00. iEALTH GRIT. Our own formula for pigeons. 5 lbs. 25c; 12 Ibs. 50c; 28 lbs. $\$ 1.00 ; 100$ lbs. $\$ 2.25$.

SALT CAT. Aids digestion. "Grey" is regular; "Red" is for bowel trouble. Per brick 20c; by mail 25c.

MOE'S GALVANIZED NEST. 8-inch, fastens at bottom. Generally used in pairs. Each 15c. By mail 20c.

MOE'S PIGEON FEEDER, No. 106. Prevents waste; a very practical feeder; holds 6 quarts. \$1.50.

GALVANIZED WATERERS. 1 gal., No. $13475 \mathrm{c}$, by main $90 \mathrm{c}$ 2-gal. No. $13590 \mathrm{c}$, by mail $\$ 1.05$.

GRIT AND SHELL BOX. For pigeons. See page 53

LEG BANDS. See assortment priced on page 56 .

TOBACCO STEMS. To use in nests. Lb. 10c; 3 lbs. 25c; 10 Ibs. 50c. Postage extra.

\section{CALF MEAL}

Calf Meal is a standard article and always beneficial. Will push calves forward quicker than any other food; also good for goats and rabbits.

BLATCHFORD'S. A well-known brand. Directions in each sack. 25-lb. sack \$1.50; $100-\mathrm{lb}$. sack $\$ 5.50$; not prepaid.

\section{GOOD BOOKS FOR POULTRYMEN-ALL POSTPAID}

Many other popular books in stock; if any special publication is wanted, ask us about it.

Each

$\$ 2.59$

Artificial I ncubating and Brooding, 112 p. ills

Artificial Light to Increase Egg Production, 112 pp., ills.,

Campines; Silver and Göiden, by Platt; 88 pp., color campines

Call of the Hen, Hogan's latest edition; very valuable work, cloth

Farm Pouitry Pays, 72 pp., ills

Fundamentals in Poustry Breeding, new, $160 \mathrm{pp}$., ills..

High Egg Production. Illustrated; paper

Minorcas, by Northrup; 50 pp.. paper

Orpingtons: Black, Buff and White; 80 pp., ills...

\section{GOOD BOOKS}

\section{0}

.40

2.00

.15

1.00

1.00

.50
.40

Plymouth Rock Standards, breed book, well illustrated, 432 pp.. cloth.

Poultry for Exhibition, growing, showing, judging, etc..,

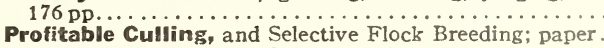
Reliable Poultry Remedies, revised, $96 \mathrm{pp}$

Success With Hogs. Cloth.

Wyandottes, All Varieties, 160 pp., color plates.

Rellable Poultry Journal, monthly; per year $50 \mathrm{c}$; 2 years for $\$ 1.00 ; 3$ years.

American Poultry Journal, monthly; per year $75 \mathrm{c} ; 2$ yrs.

\section{FOR RABBIT BREEDERS}




\section{Dog Foods and Supplies}

\section{DOG FOODS}

Prices for following Dog Foods are net, f, o. b. Denver, subject AUSTIN'S DOG BREAD. Per lb. 15c; 10 lbs. \$1.25; 25 Ibs. $\$ 3.00$; $100-1 b$. box $\$ 11.00$.

AUSTIN'S PUPPY BREAD. Per lb. 15c; 10 lbs. \$1.30; 25 lbs. $\$ 3.15 ; 100$ lbs. $\$ 11.50$.

BENNETT'S MALTOID MILK-

BONE. Bone-shaped. For dogs.

large carton, 31 ozs. 45 ; for puppies, small carton, 10 ozs. $20 \mathrm{c} ;$ dozen $\$ 2.20$; large cartons, 28 ozs., $45 \mathrm{c}$; dozen $\$ 4.75$.
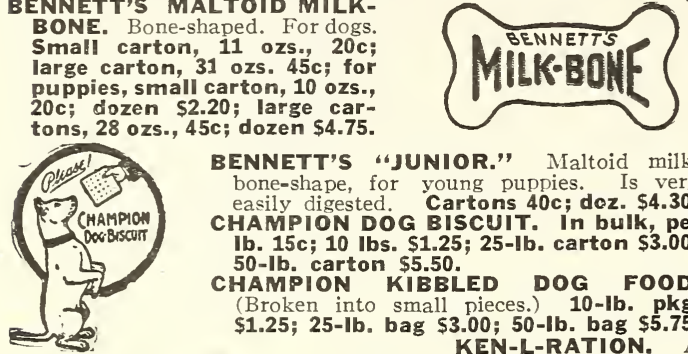

BENNETT'S “JUNIOR." Maltoid milk, Eher for easily digested. Cartons $40 \mathrm{c}$; doz, $\$ 4.30$. CHAMPION DOG BISCUIT. In bulk, per Ib. $15 \mathrm{c} ; 10 \mathrm{lbs}$. $\$ 1.25 ; 25$-lb. carton $\$ 3.00$; 50 -lb. carton $\$ 5.50$

CHAMPION KIBBLED DOG FOOD. (Broken into small pieces.) 10-lb. pkg. KEN-L-RATION.

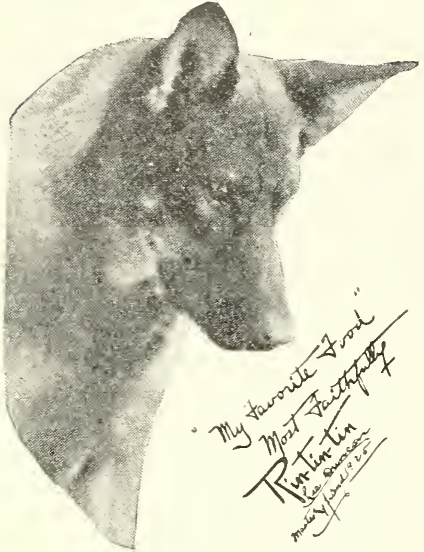
prepared meat food in 1 -pound cans, 1 12 for $\$ 1.80$; case of 48 cans $\$ 6.50$.

PUP-E-RATION. EXpressly for young dogs. 1-lb. can 20c; 3 for $50 \mathrm{c} ; 12$ for
$\$ 1.92 ;$ case of 48 cans for $\$ 7.00$

KEN-L-BISKITS. Cakes. Per carton 35c; 3 cartons for $\$ 1.00$. In bulk: Lb. $15 \mathrm{c}$; 10 lbs. $\$ 1.25 ; 25$ lbs. $\$ 3.00$; $100 \mathrm{lbs}$ \$11.00.

KIB-L-BISKITS. Kibbled. Carton $35 \mathrm{c}$ 3 cartons $\$ 1.00$. "KIPPY." Specially prepared for dogs, oz. can $10 \mathrm{c} ; \$ 1.00 \mathrm{a}$ dozen: case, 48 cans dozen; case, 48 cans
for $\$ 3.50$. $16-0 z$. size $15 \mathrm{c}$ each; 24 for $\$ 3.00$.

CALO DOG FOOD. Prepared cooked food in 1-lb. cans. 1 can $20 \mathrm{c}$; 3 for $50 \mathrm{c} ; 12$ for $\$ 1.80 ; 48$ for $\$ 6.00$

CALO PUPPY FOOD. Prom $20 \mathrm{c} ; 3$ for $50 \mathrm{c}$; 12 for $\$ 1.80 ; 48$ for $\$ 6.00$.

VITAL FOOD. For dogs, A meat and cereal preparation. Nade in Denver. 2-lb. carton 25c; 10-1b. bas $\$ 1.00 ; 25-1 b$. bag $\$ 2.25 ; 50-1 \mathrm{~b}$. bag $\$ 3.75 ; 100-1 \mathrm{~b}$, bag $\$ 7.00$.

PURINA $\$ 2.25$; $50-1 \mathrm{~b}$. bag $\$ 3.75$; $100-\mathrm{lb}$. bag $\$ 7.00$. 1 lb. $15 \mathrm{c} ; 2$ Ibs. for $25 \mathrm{c}$; 5 lbs. for." 50 c; 25 lbs. for $\$ 2.25 ; 100 \mathrm{lbs}$. $\$ 8.00$. MORSE'S MORSELS. The correct food for dog or puppy. Package 40c.

\section{DOG REMEDIES}

\section{ALL POSTPAID}

Ask for free books on Q.-W., Spratt's and Clayton's Dog Remedies.

ff. Vermicide Capsules. 3-in-1 combination for

No. 1 - 20 capsules, for dogs. Pkg.

No. 2-20 capsules, for puppies $\mathrm{Pkg}$

strictly high grade cleanser and disinfectant. 4-oz. cake $20 \mathrm{c}$.

\section{SPRATT'S REMEDIES}

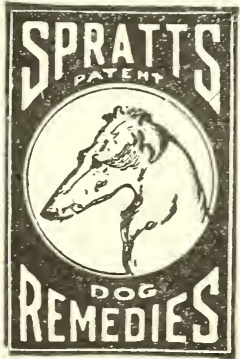

ALTERATIVE TABLETS. $60 \mathrm{c}$.

"SPECIAL TABLETS." Distemper

FLEA POWDER. 30c.

LAXATIVE TABLETS. $600^{\circ}$ LETS. 60c.

CAPSULES FOR ASCARIDS an large round worms in dogs. 60c. large round worms in puppies. 60c. LETS FOR TOY DOGS AND PUPPIES. $60 \mathrm{c}$.

"SPECIAL"; TABLETS FOR TOY

DOGS AND PUPPIES. Distem

per remedy. \$1.00.

Ask for Spratt's Booklet giving complete list of remedies. remedy. $\$ 1.00$.

TONIC AND CONDITION TAB-
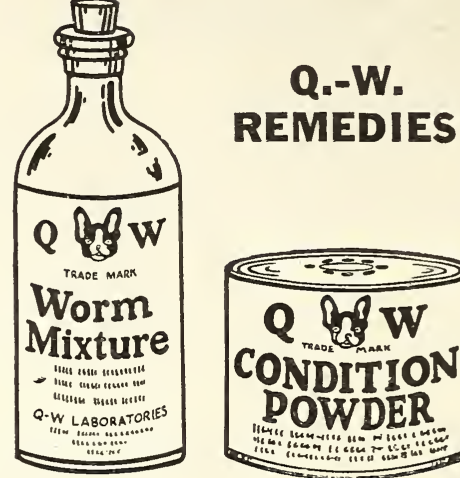

Are recognized as the highest standard among dog fanciers. We are fortunate in having the complete line ready for your quick Lovers tells you all about them.

\section{LEADING Q.-W. REMEDIES}

CONDITION POWDER. Corrects constipation and purifies the blood. Can $\$ 1.00$. CONSTIPATION PILLS. Safe laxative.

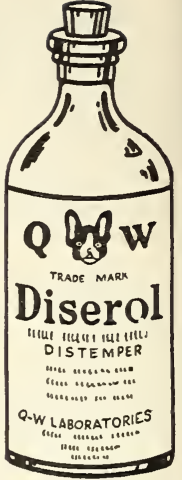

Bottle $\$ 1.00$

COD-LIVER OIL COMPOUND. For general debility, distemper rickets, etc. Pint \$1.25; quart \$2.00.

ISTEMPEROL. For treating distemper, chorea and paralysis. Bottle $\$ 2.00$.

MANGE LOTION. For mange, itch. Bottle $\mathbf{\$ 1 . 0 0}$.

SULPHUR COMPOUND. For blood diseases. Bottle \$1.00.

HEALING SALVE. A quick healer. Should be in every house.

WORM $\$ 1.00$. WORM CAPSULES. For grown dogs. Small box 65 c. Tin box $\$ 1.00$.

TAPEWORM MIXTURE. Usually effective. 2-oz bottle $\$ 1.00$ LINAMENT. For rheumatism, strains, etc. Bottle \$1.25.

DIARRHOEA TABLETS. Instantaneous, effective and soothing. Bottle \$1.25.

EYE SALVE. For sore eyes. Jar $\$ \mathbf{1 . 0 0}$.

BREEDING TABLETS. Highly approved, Bottle $\$ 2.00$

DOG SOAP. Cake form. Per cake 35c; 3 cakes in a box for $\$ 1.00$.

BOOK “ALL ABOUT DOGS" $\$ 1.00$. Other Q.-W. Remedies, Books, etc., are in stock.

\section{CLAYTON'S REMEDIES}

SARCOPTIC MANGE MEDICINE. 60C.

SKIN LOTION. 60c.

KETERALINE' (Liquid and tablets). For reducing fever and coughs due to colds. $60 \mathrm{c}$.

CONDITION PILLS WITH PEPSIN. 60C.

ALTERATIVE PILLS. Are an Arsenic, Iron and Sulphur Compound. 60c. Stimulant to the appetite. $60 \mathrm{c}$.

LAXATIVE TABLETS. $60 \mathrm{c}$. WORM PILLS. 60c.

TAPE WORM EXPELLER. $60 \mathrm{c}$.

VERMIFUGE, Liquid and

also soft capsules. $60 \mathrm{C}$.

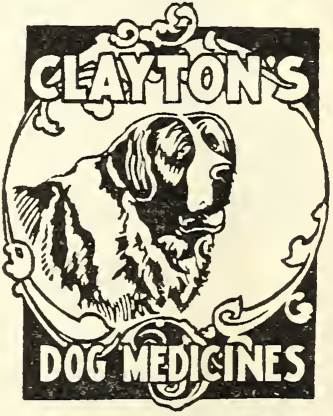

LITTLE RED WORM BULLETS. For toy puppies and toy dogs. 60c.

CANKER LOTION (Liquid and Tablets). $.60 \mathrm{c}$

EYE LOTION (Liquid and Tablets). 60c.

SEDATIVE MEDICINE (Liquid and Tablets). A nerve sedative for dogs. 60 c.

COUGH SYRUP. 60c.

PUPPY TONIC. 60c.

DIURETIC TABLETS. For muscular aches. 60c.

BOWEL CONSTRINGENT (Liquid and Tablets). $60 \mathrm{c}$.

CEOLINE DOG WASH AND DISINFECTANT. $35 \mathrm{c}$.

KILFLEA SOAP. For fleas. 25c.

KILFLEA POWDER. For dogs and cats. 35c.

Ask for Booklet giving a complete list of Clayton's Remedies.

ITEMS LISTED ON THIS PAGE ARE NOT POSTPAID UNLESS SO STATED. SEE PARCEL POST RATES ON PAGE 64. 


\section{Canary Birds - The Ideal Pets}

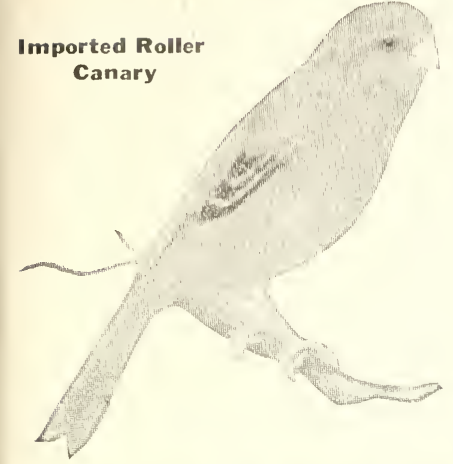

Our birds are all strong and active fivery singer by us as a singer. We cannot send out on trial or exchange lifolse Statc the amomut you birds are graded as to singing qualities and range of notes.

Hartz Mountain Strain

These are the popular singers and usuatly are mixed in phunthe vigorous. Our domestic bred are very lealtiy and satistactor

"X" GRADE. With fair song. Price according to song and plumage. \$5.00 and \$6.00. "XX" GRADE. A reasonably good song, though not much varicty in notr.s. Each $\$ 7,50$ and $\$ 8.00$.

"XXX" GRADE. Extra good in all respects. Each $\$ 10.00$. IMPORTED ROLLERS.

St. Andreasburg and Seifert stock are both available now from (sch.

have a varicty in stock. Their price depends on the rolls and notcs.

EXTRA SELECT MALES. German trained. Each $\$ 12.00$. A few at $\$ 15.00$. FEMALE BIRDS FOR BREEDING.

DOMESTIC. Dark; also mixed. Each $\$ 1.50$

DOMESTIC. Yellow.

IMPORTED. Roller Stock. Each $\$ 3.00$ to $\$ 5.00$.

We pack and deliver to express office, Denver. They usually carry safely anywherc

Book Free With Birds. A book covering care, feeding and breeding of Canary birds. Sells for 10c.

\section{BIRD FOODS IN BULK}

Prices Subject to Change. Add postage whem wanted by

'DEPENDAELE GRADE' MIXED ROLLER BIRD SEED. Our best grade; such as we feed. In 1-1b. cartons 20c; 2-1b. pkg. for 35c. Also in bulls: $10 \mathrm{lbs}$. $\$ 1.60 ; 25 \mathrm{lbs}$. for $\$ 3.75$. Special Offer, 5 -ibs. this bird seed, postpaid, for $\$ 1.00$.

CANARY, IMPORTED. Recleaned. $1 \mathrm{lb}$. 20c; 2 lbs. 35c; 10 lbs. $\$ 1.50$ : 25 lbs. $\$ 3.00 ; 100$ lbs. $\$ 10.00$.

CANARY, GIANT SPANISH. Large seed. Lb. 25c; 10 lbs. $\$ 2,25$.

HEMP. Imported. $1 \mathrm{ab} .15 \mathrm{c} ; 2$ lbs. $25 \mathrm{c} ; 10$ lbs. \$1.00; 25 lbs. $\$ 2.00 ; 100$ bbs. $\$ 7.00$

RAPE. Bird. Sweet; imported. 1 lb. 20c; 2 8bs: 35c; 10 lbs, $\$ 1.60 ; 25$ lbs. $\$ 3.50 ; 100$ lbs. $\$ 12.00$

RAPE, ESSEX. $1 \mathrm{lb}$. 20c; 2 lbs. 35c; 10 lbs. $\$ 1.50 ; 25$ lbs. $\$ 3.00 ; 100$ lbs. $\$ 10.00$.

LETTUCE SEED. White. 1/4 lb. 15c; lb. 50c; 10 lbs. $\$ 4.00$. POPPY SEED. Blue. 3 ozs. $10 \mathrm{c} ; \mathrm{lb}$. $40 \mathrm{c} ; 10 \mathrm{lbs}$. $\$ 3.00$.

THISTLE, BLACK. Imported. $1 / 4 \mathrm{lb} .15 \mathrm{c} ; \mathrm{lb} .50 \mathrm{c}$

UNHULLED RICE. $1 / 4 \mathrm{lb}$. 10c; $1 \mathrm{ib}$. $25 \mathrm{c}$ : $10 \mathrm{lbs} . \$ 2.00$

MILLET. Large, yellow. $1 \mathrm{lb} .10 \mathrm{c} ; 2$ ibs. 15c; $10 \mathrm{lbs} .70 \mathrm{c}$; 25 Ibs. $\$ 1.25$; 100 lbs. $\$ 3.50$

BIRD SAND. "White Bermuda." Pkg. 10c; 10 lbs. 40c; 25 lbs. $90 \mathrm{c} ; 50$ lbs. $\$ 1.50 ; 100$ lbs. $\$ 2.50$.

SUNFLOWER. Selected and recleaned; for Parrots. $1 \mathrm{lb} . \mathbf{1 5 c}$ 10 lbs. $\$ 1.15 ; 25$ tbs. $\$ 2.50 ; 100$ lbs. $\$ 9.00$. PARAKEET SEED. Our own formula. $1 \mathrm{lb}$. 20c; 2-lb. pkg.

SMALL RED PEPPERS. $1 / 4 \mathrm{lb} .20 \mathrm{c} ; 1 \mathrm{lb} .65 \mathrm{c}$

CUTTLE BONE. Average size pieces. Each 10c; 3 for 25c; $1 / 2 \mathrm{Hb}$. 50c: $1 \mathrm{tb} .80 \mathrm{c}$.

WILD BIRD SEED. Feed the wild birds in winter. 4 lbs. $25 \mathrm{c}$; 9 lbs. 50c; 20 lbs. $\$ 1.00 ; 100$ lbs. $\$ 4.00$.

\section{BIRD SEED IN CARTONS}

IF YANTED BY MAIL, ADD POSTAGE.

"DEPENDABLE GRADE" MIXED ROL-

LER BIRD SEED. The kind we feed.

Lb. $20 \mathrm{c}$.

MAX GEISLER'S RDLLER BIRD SEED. Per pkg. 30c.

PHILADELPHIA BIRD SEED. Premier. 14-0z. carton 25c.

SPRATT'S CANARY MIXTURE. With egg

flake and fruit. Pound cartons $30 \mathrm{c}$.

FRENCH'S MIXED BIRD SEED. 15c.

MOCKING BIRD FOOD. McAllister. In

tins. Each 45c.

PARAKEET SRED. 12-0z. plkg. 25c.

JAVA-SPARROW SEED. 16-oz. pkg. 25.

GOLDFINCH SEED, 15-0z. pkg. 30c.

"DEPENDAELE GRADE" MIXED PAR-

Q ROT FOOD. Contains sunflower, hemp,

\section{MISCELEANEOUS}

GRAVEL PAPER. A special paper with gravel affixed like

' sandpaper. Per 12 sheets. .................... inch. 25 sheets $20 c^{\circ} 100$ sheets $60 \mathrm{c}$.

LICE AND MITE POWDERS. "Our Dependable" Mite Powder. Very effective. Postpaid.

RED MITE EXTERMINATOR. Philadelphia. Per pkg. LICE POWDER. 11/4 OZs., in a powder gun; ready for use POWDER GUNS. Separate. Each.

SPRATT'S RED MITE TRAP

Add postage when any above are wanted by mail.

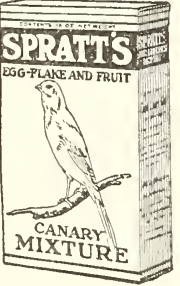

BIRD BOOKS. All postpaid. Canaries and other cage birds $40 \mathrm{c}$.

Parrots and Other Talking Birds 35c.

CANARIES. Spratt's English Puhlication. 48 pages. 25c.

ENCYCLOPEDIA OF RIRDS (New). Paper cover 75c; cloth $\$ 1.50$.
BIRD PREPARATIONS ARd FOODS IF WANTED BY MAIL, ADD POSTAGE.

"DEPENDABLE" SONG RESTORER. A tonic and cold

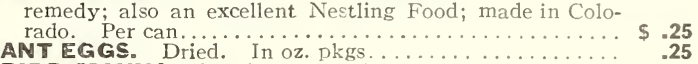

BIRD MANNA. Ready to attach to cage; very popular.

BURNETT'S UNRX X ELLED BIRD FOND. In glass jars.

BURNETT'S LIGHTNING REGULATOR. In tin cans. $\quad .20$

BIRD BITTERS. Philadelphia. Bitter Iron Tonic. Bottle .25

BIRD EYE WATER. For sore eyes. Per bottle...... .25

COLOR FOOD. For giving color to Canaries' plumage.. .25

SONG RESTORER. Drahoto's.........................

MERICAN SALVE. For lameness, sores, etc. Per pkg. .25

NESTLING FOOD. Philadelphia. Per pkg.............25

PLUMAGE RESTORER. A tonic food............... .20

MALLER'S DUTCH SONG RESTORER Very popular .25

HALLER'S BIRD PIE. 2 for $25 c \ldots \ldots \ldots \ldots \ldots \ldots \ldots$

HALLER'S HA-HA SONG FOOD ...............

WEST'S WILD GRASS SEED. Per carton............ $\quad .20$

\section{GEISLER'S PREPARATIONS}

GEISLER'S VEGETABLE EXTPACT. For birds; a tonic. Each Per bottle.

EISLER'S TONICS. "A" for Song Restorer; "B" for

indigestion; "C" for colds; "D" as a general tonic. Each. $\quad .25$

GEISLER'S MOULTING FOOD. Per pkg...........

GEISLER'S ROLLER BIRD SEED. Per carton........

GEISLER'S GERMAN BIRD BISCUITS. "Maizena."

Per pkg

GEISLER'S PARRO Tiscuirs. Per pkg.

GEISLER'S PARROT MEALTH FOOD. Per pkg.

GEISLER'S PARROT SEED. Per $\mathrm{pkg}$.

GEISLER'S PREPARED BIRD GRIT. Per pkg.

If any other of Geisler's goods wanted, please write us.

\section{"IUSTRITE" LBNE}

IF WWANTED BY MAIL, ADD

POSTAGE.

JUSTRITE SONG RESTORER.... 5.15

JUSTRITE SONG RESTORER. Large

JUSTRITE HONEY ROLL.' 2 for 25 c JUSTRITE MOULTING FOOD

JUSTRITE VITAMINE HEALTH FOOD

JUSTRITE RIRD EITTERS.

JUSTRITE WILD GRASS SERD.

HUSTRITE MIXED BIRD SEED.

JUSTRITE MPOED BIRE SEED.

JUSTRITE BIRD GRAYEL. Brown.

IUSTRITE BIRD GRAYEL.

JUSTRITE BIRD GRAUEL. Silver.

JUSTRITE FLAKE CHARCOAL.
JUSTRITE BALM FOR BALDNESS.

DUSTRITE FEATHER PULLING

REMEDY

USTRITE COLOR AND PEPPER

FOOD

MUSTRITE ROLLER SEED

JUSTRITE RIRD WASH

JUSTRITE RIRD WASH FOOD

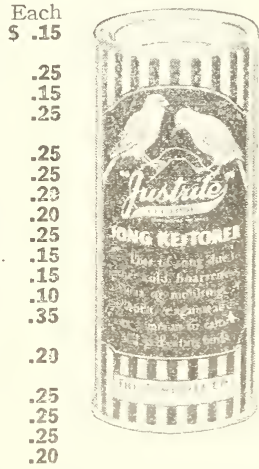

FREE LEAFLET- "THE CARE OF THE CANARY", ALL ABOUT FEED, WATER, GENERAL CARE, ETC. ASK FOR IT WITH YOUR ORDERS FOR OTHER GOODS. 


\section{KAEMPFER'S BIRD FOODS}

In original cartons. Postage extra.

KAEMPFER'S BIG KERNEL BIRD SEED. Lb. pkg... \$ .25

KAEMPFER'S GOLDFINCH SEED, 15-0Z, pkg. .....

KAEMPFER'S JAVA SPARROW SEED. 16-oz. pkg.

KAEMPFER'S MOCKING BIRD FOOD. 12-oz. pkg.

KAEMPFER'S PARAKEET, SEED. 16-oz. pkg. .

KAEMPFER'S POPPY SEED. 3-oz. pkg.

KAEMPFER'S STEEL CUT OATS. 6-oz. pkg

KAEMPFER'S UNHULLED RICE. 14-oz. pkg

KAEMPFER'S CANARY HIGHBALL

KAEMPFER'S BIRDOLENE.

When ordering above, please mention "Kaempfers."
SPRATT'S BIRD SUPPLIES

IF WANTED BY MAIL, ADD POSTAGE. SPRATT'S MIXED BIRD SEED. 15-OZ. pkg MiẌTURE WITH EGG FLAKE AND FRUIT SPRATT'S COD LIVER OIF NEST: SPRATT'S MOULTING FOOD. SPRATT'S SÖNG RESTTÖRER. 4 -oZ. SPRAT̈ंS̈ SiNG SÖNG. in smail tin SPRATT'S BIRD WASH. 3-oz. bottles CANARYDYNE, FOR ASTHMA.

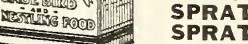
SPRATT'S PARAKEET MIXTURE

SPRATT'S FINCH BIRD SEED MIXTUURE SPRATT'S LOVE BIRD SEED

\section{CAGE EQUIPMENT}

ADD POSTAGE WHEN WANTED BY MAIL

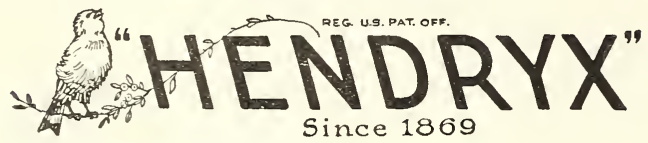

All are complete with seed and

vater cups, perches and a swing.

Order by the number.

ROUND BRASS CAGES

With Brass Wire Guard, Flange

Base. Unquestionably the

Base. Unquestionably the

best style of the popular-priced,

illustration.

No. $274-101 / 8$ - inch

diameter. Each

$\$ 3.70$

No. $275-11$-inch diam-

eter. Each

4.25

$276-113 / 4$ - inch

4.90

Same Style, with Flat Basin

Base. Self-locking base hooks:

removable inside mat.

No. $1274-10 \frac{1}{8}$-inch

diameter. Each.... $\$ \mathbf{\$ 3 0}$

No. $1275-11$-in. diam-

\subsection{5}

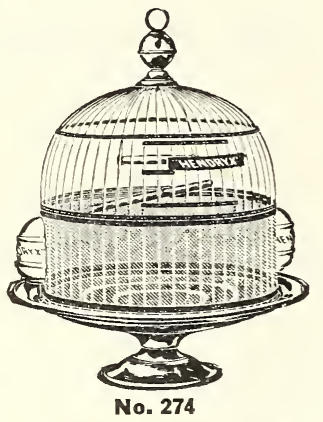

No. 1276-113/4-inch diameter.

Each

$\$ 4.90$

Same Style as Above, Except Base is Flange. Satin dip, new

style, flat base.

No. $2274-101 / 8$-inch diameter. Each.

No. 2275-11-inch diameter. Each.

$\$ 3.70$

4.25
4.90

Same Style of Brass Cage, with Duco-Colored Trimmings, such as Red, Green and Blue. Very attractive.

No. 2274TT-101/8-inch diameter. Each

No. 2275T T-11-inch diameter. Each.

$\$ 4.00$

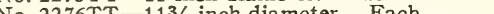

Same Shape of Brass Cage as Above, Having Broader Base

Band. Two colors. Latest in bird cage colors.

No. 3274-101/8-inch diameter. Each.

Base

No. 3275-11-inch diameter. Each.

$\$ 4.20$

Hendrix Special Cage. In Nile Green, Red, and Blue; each cage

with tassel on bottom of cage. A remarkably good cage at LARGE CAGES-FOR AVIARY White

No. 1. 201/4-in. long, 12 in. wide.

No. 2. $22 \mathrm{in.} \mathrm{long,} 13 \mathrm{in}$. wide.

CANARY TRAVELING CAGES-Enameled

No. 91-H. Size $71 / 2 \times 53 / 4$, height 5 inches $\$ 1.60$

No. $911 / 2-H_{\text {. }}$ Round, 7 -inch diameter

by $51 / 2$ inches high.

1.90

\section{BREEDING CAGES}

ENAMELED-SLIDING DRAWER-Single

No. SB-H. $13^{5} / \mathrm{ex} 8$ inches, height $13 \mathrm{in}$. $\$ 5.15$ DOUBLE, WITH PARTITION

No. $865-H .171 / 4 \times 83 / 4$ in., height $13 \frac{1}{4}$

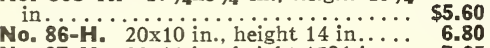

No. 87-H. $22 \times 11$ in., height $153 / 4$ in... 7.65 CAGE STANDS

No. 39-A. Polished brass.' Single loop. $\$ 3.00$

No. 40-A. Polished brass. Double loop 4.00

No. 57. Two-tone, in red, green and

blue. Single loop.

2.80

No. 58. Two-tone, in red, green and

blue Double loop ................ 3.25

Hendrix Special Stand, to go with 3.25

ages No.A.S. In green, red, and blue $\mathbf{2 . 5 0}$

We usually have in stock many popular styles of cages and stands not shown in this list. What we have enumerated are all strictly tandard patterns.

We make no charge for packing; however, if wanted by mail, postage is extra. Much depends on style and packing weight.
. $\quad \begin{array}{r}\$ 7.75 \\ 9.15\end{array}$ 10.10

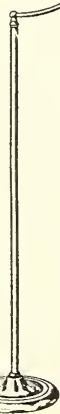

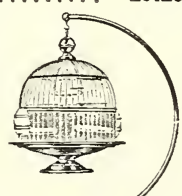

$\$ .25$

.25
CRYSTAL WATER FOUNT. Can be attached anywhere

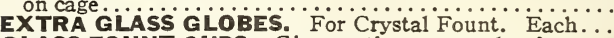

GLASS FOUNT CUPS. Give continuous supply of water.

"TIN WELL" DRINKING CUP. Does not spill. With

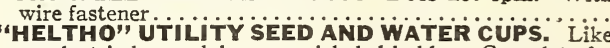
CAGE GUARDS, BRASS WIRE CLOTH. Cut to order. $31 / 2$-inch, per foot.

5-inch, per foo

or wire cloth; extra. 6 for.

CHARM BELLS. Tiny bells to hang on cage. Each PERCH MATERIAL. 1/2-inch round. 3-foot piece for... PERCHES. All lengths, plain wood; give size wanted. SEED AND WATER CüPS. " "Single Point, ; porcelain; also glass; either, 2 for 25 c; each ..................... SEED AND WATER CUPS. Open top, "Tulip Cup," por SEED AND WATER CUPS. Closed top, "Shell," porcelain.

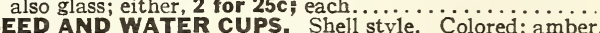
HENDRIX SQUARE GLASS CUPS. For breeding cage.

CANARY CUPS. 2 inches diameter, small, round, oval.. FOOD HOLDER CUPS. Oval, small, fasten between wires. 3 for $25 \mathrm{c}$; dozen $80 \mathrm{c}$; each.

FOOD HOLDER CUPS. No. 4 , tin plated a CUTTLE BONE HOLDER. Hendryx No. 1. To hold

SATH DISHES. Porcelain, oval shape, medium size. Each BATH DISHES. Glass, oval shape, medium size. Each. LARGE BATH DISHES. Glass and porcelain. Each. BIRD BATH. New pattern. No. 3, celluloid and mica, in red, green and blue.

BIRD BATHS. Celluloid. No. 0142. Imported.

BIRD CAGE NESTS. Wire cloth, 4 inches diameter. 2

for 35c; each . NESTS. " Shallow

NESTING HAIR. Per pkg...

SWINGS, PLAIN. Each.

SWING WITH KNOB. Complete. Each

SUN ARM. A metal bracket to fit over picture moulding on wall and hold cage out from the wall. Assorted colors... CAGE SPRING, No. 160. Single, light brass plated. Each CAGE SPRING, No. 16. Single coil brass. Each. ..... CAGE SPRING, No. 14. Single coil, brass, heavy, Each justable.

CAGE SPRING, No, 19. Double coil brass, prevents cage SAGE BRACKET. Nickeled or brass plated, swinging. No. 10 wire, 8-inch. Each................................. CAGE BRACKET. Nickeled or brass plated, swinging. No. 9 wire, 10 -inch. Each ..................... Brass plated, heavy, swinging, No.

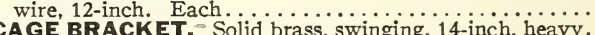
SHIPPING CUPS. Tin. No.2, for water. Each...... LEG BANDS FOR BIRDS. Imported, numbered." Doz. BIRD WARBLER. Celluloid, fill with water and blow.

BIRD CAGE COVERS. Made of heavy cretonne cloth to protect at night or cold drafts. For average square, oblong and rounc cage. In assorted colors, $\$ 1.00$, postpaid.

\section{BIRD BATHS FOR THE LAWN}

Terra cotta style. Made two-piece.

No. 116. 20 inches tall.................... \$6.00 No. 723. 24 inches tall, 19 inches wide; top bolts on..... 9.90 Ornamental Crane Bird, solid metal, decorated, to place

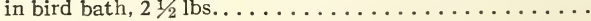

\section{FEED FOR WILD BIRDS}

Our own mixture, consisting of hemp, millet, broken wheat, etc. 4 Ibs. 25 c; 9 Ibs. 50c; 20 Ibs. $\$ 1.00$.

If wanted by mail, add postage at zone rates. See page 64 .

62 
IF WANTED BY MAIL, ADD 25C EACH

We have an assortment suitable for placing in trees, on barns, sheds, etc.

WREN HOUSE. Green silicate finish. Each 35c; 3 for $\$ \mathbf{1 . 0 0}$. BIRD FEEDING HOUSE. Silicate finish. Each 60c.

THE ART SET-

RUSTIC CEDAR BIRD HOUSES. "Crescent" Make.

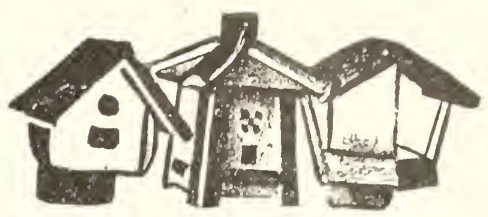

COUNTRY LIFE SET

No. 11. Cottage style; for Vrens.

No. 13. Low log cabin style; for IVrens.

2.00

NATURE SET-

No. 30. Oval shape; for Wrens............. 2.00

No. 31. Cottage pattern; for Bluebirds.... 2.00

No. 32. Shelter for Robins................. 2.00

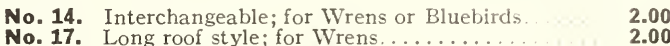

$\begin{array}{ll}\text { No. 17. Long roof style; for IVrens............... } & \mathbf{2 . 0 0} \\ \text { No. 63. Combination House; for Robins . . . . . } & \mathbf{2 . 0 0}\end{array}$

No. 21. Upright shape; for Bluebirds............ $\mathbf{\$ 2 . 0 0}$

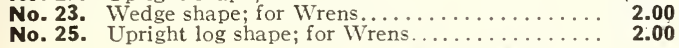
Any three above in one purchase for $\$ 5.50$

Prices for these Plants Subject to Change and Stock Being Yet Unsold Special Spring Price List

BED
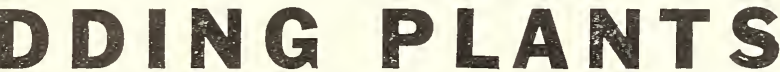

Pansies and

Asters listed on page 17

This stock is ready through April and May, or as season is suitable. Prices are net, f. o. b., our store. We recommend shipments by express only; if must go by mail, add sufficient postage. Potted plants are removed from pots with soil on roots, then carefully wrapped. Potted plants-six at the dozen rate; 50 at the 100 rate.

ALYSSUM, Sweet, from 2-in. pots.

ANTIRRHINUM, Snapdragons, assorted, from 3 -inch pots.

Each Per 12

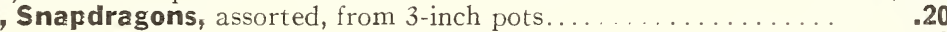

ASPARAGUS, Springerii, from 4-inch pots

2 -inch pots.

5.70

3 -inch pots

CANNAS, well started from 4 -inch pots.....
COLEUS, assorted, from 2 and $2 \frac{1}{2}$-inch pots.

.80

COLEUS, assorted, from 2 and $2 \frac{1}{2}$-inch pots

2.00

3-inch pots. .

3.00

CALIFORNIA PINKS, from 2-inch pots..

1.00

3 -inch pots.

2.00

1.00

2.00

COBEA SCANDENS, beautiful climbers .

3.00

DRACENAS, from 4 -inch pots.

3.00

DUSTY MILLER, Centaurea, from 2-inch pots.

FERNS, SMALL TABLE, assorted, from 3-inch pots

2.00

GERANIUMS, from 4 -inch pots.

$$
3 \text {-inch pots (when in stock). }
$$

GERANIUMS, Madam Salleroi, from 2-inch pots.

HELIOTROPE, from 3 -inch pots (when in stock). 4-inch pots. .

IVY, English Climber, 3 -inch pots

3.00

LOBELIA, Dwarf, from 2-inch pots.

.80

LOBELIA, Trailing, from 2 -inch pots.

MARGUER ITES, White Single, from 3 -inch pots.

4 -inch pots

MARGUERITES, Yellow

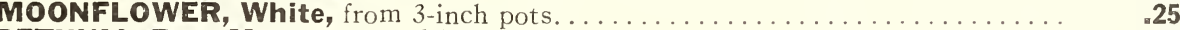

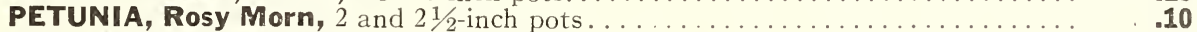

PETUNIA, Single Giants, from 3 -inch pots.

PEUNA, Double Assorted, from 3 -inch pots

VERBENAS, Assorted, from 2 and $2 \frac{1}{2}$-inch pots

VINCAS, Green, also Variegated, from 4 -inch pots

\section{Bedding Plants-Seedlings}

ANTIRRHINUMS, Mixed Colors

ASTERS, Giant Branching Comet; separate popular colors

ROWN IN HOTBEDS, ONCE TRANSPLANTED

IN GOOD CONDITION FOR RESETTING

\begin{tabular}{|c|c|}
\hline $\begin{array}{r}\text { Per Doz. } \\
5.60 \\
.50 \\
.35 \\
.60 \\
.50 \\
.60 \\
.70 \\
.70\end{array}$ & $\begin{array}{r}\text { Per } 100 \\
\$ 4.00 \\
3.50 \\
2.50 \\
4.00 \\
3.50 \\
4.00 \\
4.50 \\
4.50\end{array}$ \\
\hline
\end{tabular}

.00
.00
.00
.00
.00
00
.00
.00
.00




\section{Special Garden Books}

\section{Prices Postpaid}

ADVENTURES IN DISH GARDENING. (Beard) ills. $220 \mathrm{pp}$. Tells how to make with growing plants, stones, miniature garden in bowls. $\$ 2.50$.

ANNUALS, LITTLE BOOK OF. (Hottes) ills., 116 pp. A reliable guide to culture on annual flowers, over 100 separate species are described and full directions for their use. $\$ \mathbf{1 1 . 5 0}$. BULBS THAT BLOOM IN THE SPRING. (Weston) ills. Written for the amateur and affords all the information the home gardener requires for the bulbs that we plant in the fall. Cloth Cover \$2.00; Paper Cover \$1.50.

CLIMBING PLANTS. (Hottes) ills. Only book obtainable combining all climbing plants, uses, etc. \$1.75.

CONSIDER THE LILIES. (Marshall). Fully illustrated in colors. $\$ 1.00$

DAMLIA CULTURE. (Waite.) Brief, clear, complete, bases on actual results of an experienced grower. $\$ 1.50$

GARDEN GUIDE. 384 pp. paper cover. Undoubtedly the most complete garden manual for the amateur. $\$ 1.00$.

HOME FLORICULTURE. (Page.) A guide for the garden and house plants. $35 \mathrm{c}$.

IRIS MANUAL. (Harrison) ills. Very complete. 25c.

LAWNS. (Rockwell) 87 pp., ills. Helps the home owner in planting, remaking or repairing his lawn. $\mathbf{\$ 1 . 0 0 .}$

MILADY'S HOUSE PLANTS. (Palmer.) Tells how to care for Palms, Ferns, Rubber Plants, Fuchsias and many others. \$1.25.
PEONY MANUAL. (Harrison) ills. 50c.

PERENNIALS, LITTLE BOOK OF. (Hottes.) Gives the general principles of growing and selecting perennials for the home grden, ills. $\$ 1.50$.

PRACTICAL FLOWER GARDEN. (Ely) $295 \mathrm{pp.}$ Those who love flowers can learn just when and how to plant almost everything. $\$ 2.50$,

PRACTICAL LANDSCAPE GARDENING. (Cridland.) Tells how to plan and plant, giving detailed sketches of where to

place your Flower, Rose or Rock garden. 276 pp. \$2.50.
PRACTICAL PLANT PROPAGATION. (Hottes.) Illustrated. Brief and pointed. $\$ 2.00$.

ROOF GARDENING. (Mellen.) Tells how to maintain a ROSE GARDEN PRIMER. (Holmes.) Ills. Tells of Rose

growing at home for pleasure. $\$ 1.75$.
ROCK GAPDEN PRIMER. (Thornton.) 70 ills., 152 pp. Written for amateurs, gives methods of planting and plants to

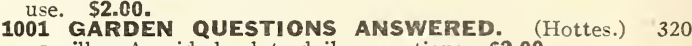
pp., ills. A guide book to daily operations. $\$ 2.00$.

VEGETABLE GARDEN. (Kruhm.) Complete instruction and suggestions. \$1.75.

"BETTER'HOMES AND GARDENS" MAGAZINE. Published monthly at Des Moines, Iowa. 1 year $60 \mathrm{c} ; 2$ years $\$ 1.00 ; \% 3$

years $\$ 1.50$. Send your order to us. Write for more complete list of Garden Books.

\section{Good Books---All Standard \\ PRICES INCLUDE POSTAGE.}

Each

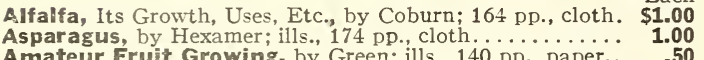

Amateur Fruit Growing, by Green; ills., 140 pp., paper..

Better Sweet Peas, by Geo. J. Ball. 57 pages of live matter

about how to profit with Sweet Peas

Book of Bulbs, by Rockwell, ills.

Cabbage, Cauliflower and Allied Vegetables, by Allen;

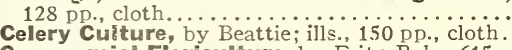

Commercial Floriculecuse, by Fritz Bahr, 615 pp.

Country Kitchen Cook Book, 600 recipes; 150 pp.

Flax Culture, paper cover.

Grow Your Own Fruitt, 84 pages, ills., paper

Home Cannimg, up-to-date methods; 80 pp. ills., paper...

Hints and Helps for Young Gardeners, by Hemenway;

Making the Farm Pay, 314 pp., cloth.

Make the Garden Pay, 80 pD., ills., paper.
New Onion Culture, by Greiner; ills., 140 pp., cloth

New Ons,

Potatoes, More and Better to the Acre, 64 pp, ills. paper

Potatoes, More and Better to the Acre, 64 pp., ills, paper .15

Seed Corn, Do you know that it will grow; 30 pp., ills.... $\begin{array}{r}\mathbf{1 1 5} \\ \text { Spraying Crops, by Weed; } 140 \text { pp., ills., cloth......... }\end{array}$

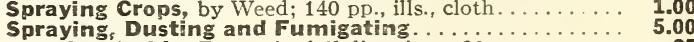

Tanning Guide; Farmer's; full directions, 33 np

Tomato Culture, by Tracy; ills., 150 pp., cloth

Vacant Government Land, How to Get Government

Land; 112 pp...

Weeds and How to Eradicate Them, by Shaw; ills., 240

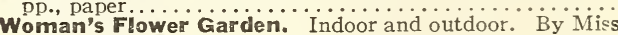

Woman's Flower Garden. Indoor and outdoor. By Miss
Kift. 160 pp., ills...........................

.25 When wanting any book on gardening, flowers, etc., and same is not in our list, send us the order, giving full title. We can usually supply all books promptly.

\section{Parcel Post Information}

We pay postage on all Vegatable and Flower Seeds, except as priced on page 39

We do not pay postage on Grass, Grain or Field Seeds, nor on Nursery Stock, such as Trees and Shrubs, unless stated otnerwise. We do not nay postage on Poultry Foods and Supplies nor Garden Tools, Sprayers, etc., unless so stated.

THE PARCEL POST rates are as follows: Owing to the convenience of having mail brought to your door by the rura! delivery system, it is weil to take advantage of the low rates.

20 pounds anywhere within the city limits of Denver for $17 \mathrm{c}$.

Nothing heavier than 50 pounds may be mailed farther than 150 miles in one package.

ZONE RATES-When it is required that postage be added to the purchase price of any commodity note the distance you are from Denver, see in which Zone you live. It is then easy to estimate the exact amount of postage required, or ask your postmaster.

FOR PARCELS WEIGHING eight ounces OR LESS, containing seeds, bulbs or books only, the rate of postage to all zones is 1 cent for two ounces or fraction. (Over eight ounces the parcel post rates apply.)

When computing the cost of articles by Parcel Post, please consult this schedule:

\section{DOMESTIC PARCEL \\ On Seeds, Plants, Bulbs, \\ Tools, Etc., Within the \\ United States and} Possessions

First Zone, Denver and within

50 miles of Denver......

miles of Denver.

Third Zone, within 150 to 300 miles of Denver.

Fourth Zone, within 300 to 600 miles of Denver.

Fifth Zone, within 600 to 1,000 miles of Denver

Sixth Zone, within 1,000 to 1,400 miles of Denver. . . . . Seventh Zone, within 1,400 to 1,800 miles of Denver

Eighth Zone. al: over 1,800

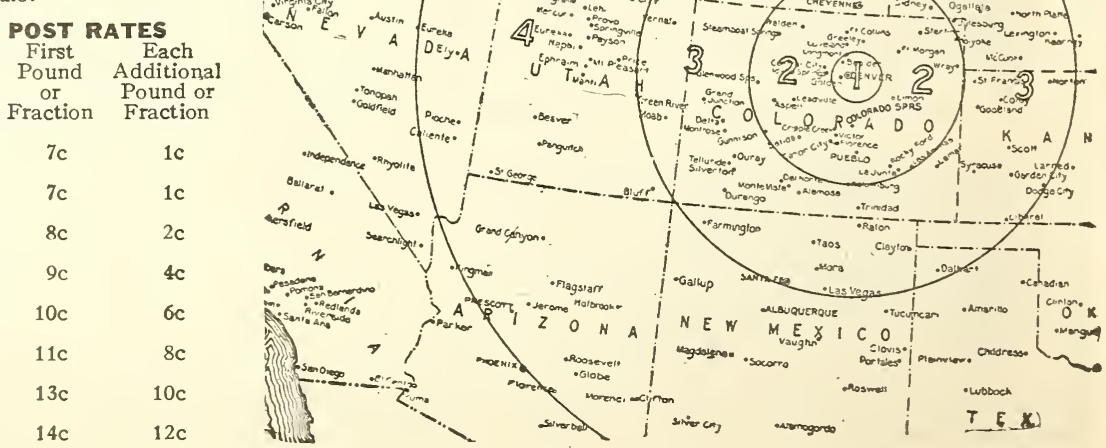




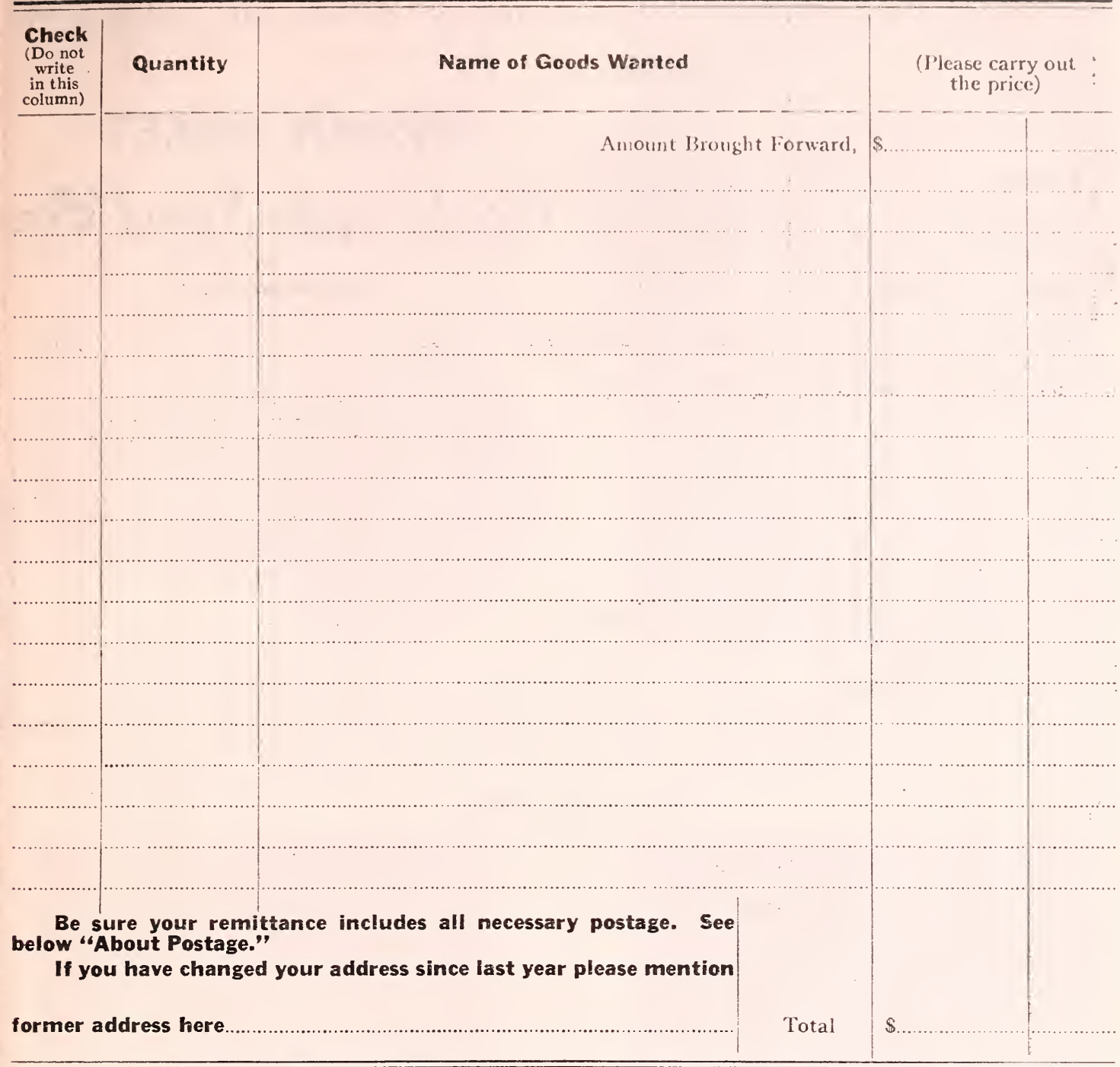

\section{ABOUT POSTAGE}

We pay postage on all Vegetable and Flower Seeds, unless stated therwise.

We do not pay postage on Grass, Grain or Field Seeds, nor on Nursery Stock, such as Trees and Shrubs, unless stated otherwise. We do not pay postage on Poultry Foods and supplies nor Garden do not pay postage on Poultry Fod

THE PARCEL POST rates are as follows: Owing to the convenience of having mail brought to your door by the rural delivery system, it is well to take advantage of the low rates.

20 pounds anywhere within the city limits of Denver for $17 \mathrm{c}$.

20 pounds one hundred and fifty miles, 26c; and $1 \mathrm{c}$ for eaci additional pound up to 70 pounds.

Nothing heavier than 50 pounds may be mailed farther than 150 miles in one package.

ZONE RATES-When it is required that postage be added to the purchase price of any commodity, note the distance you are from Denver, see in which Zone you live. It is then easy to estimate the exact amount of postage required or ask your postmaster.

FOR PARCELS WEIGHING 8 ounces OR LESS, containing seeds, bulbs or books only, the rate of postage to all zones is 1 cent for two ounces or fraction. (Over 8 ounces the parcel post rates apply.)

When computing the cost of articles by Parcel Post, please consult this schedule:

\section{DOMESTIC PAFCEL POST RATES}

On Seeds, Plants, Bulbs, Tools, Etc.

\section{Within the United States and Possessions}

First Zone, Denver and within $\mathbf{5 0}$ miles of Denver. Second Zone, within 50 to 150 miles of Denver. Third Zone, within 150 to 300 miles of Denver. Fourth Zone, within 300 to 600 miles of Denver. Fifth Zone, within 600 to 1,000 miles of Denver. Sixth Zone, within 1,000 to 1,400 miles of Denver. Seventh Zone, within 1,400 to 1,800 miles of Denver Eighth Zone, all over 1,800 miles of Denver......

\section{F R E E weather PROPHET}

With vegetable and flower seed order totaling $\$ 10.00$ Illustrated and described on page 45 .

QUAINT - PRACTICAL - INTERESTING

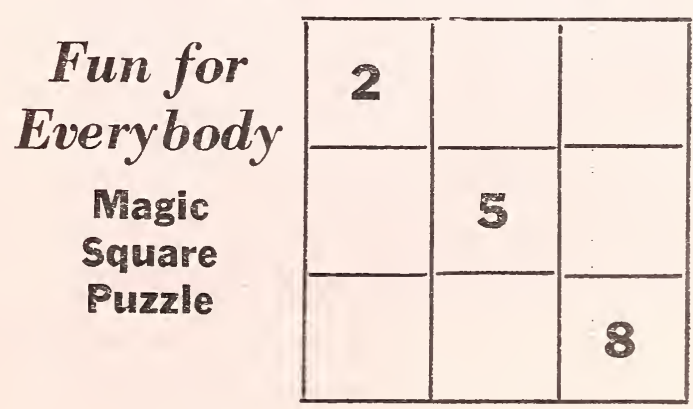

Place tlie figures $1,2,3,4,5,6,7,8$, and 9 in the squares above so that the totals, added across, up and down and diagonally will total 15 . (2, 5 and 8 are placed correctly.)

Fill in your answer in the squares above and free seeds will be included with your order. 
Use this blank if possible-It aids in filling orders promptly and properly

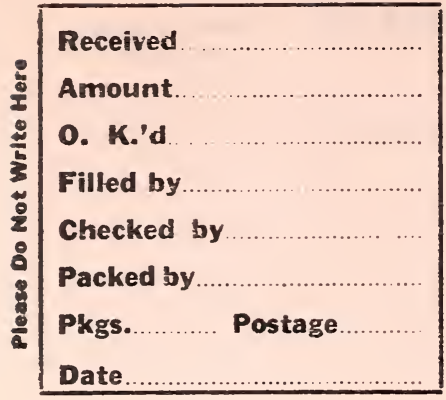
Our Order No.

Gentlemen: Please forward the following goods by

(Mail, Express or Freight)

\section{P. O. Box 1345}

Phore KEystone 1351 Date..

193

\section{Champa Street}

Name

Postoffice

R. D. or Street

State

Express or Freight Ofîce

if different from Postoffice

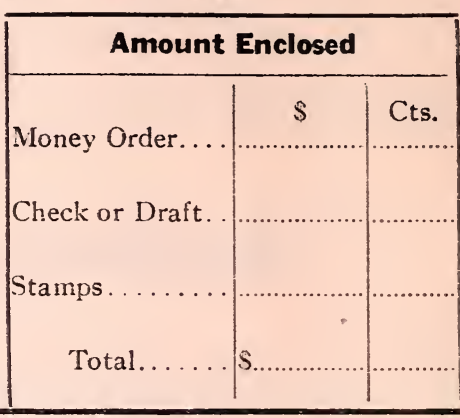

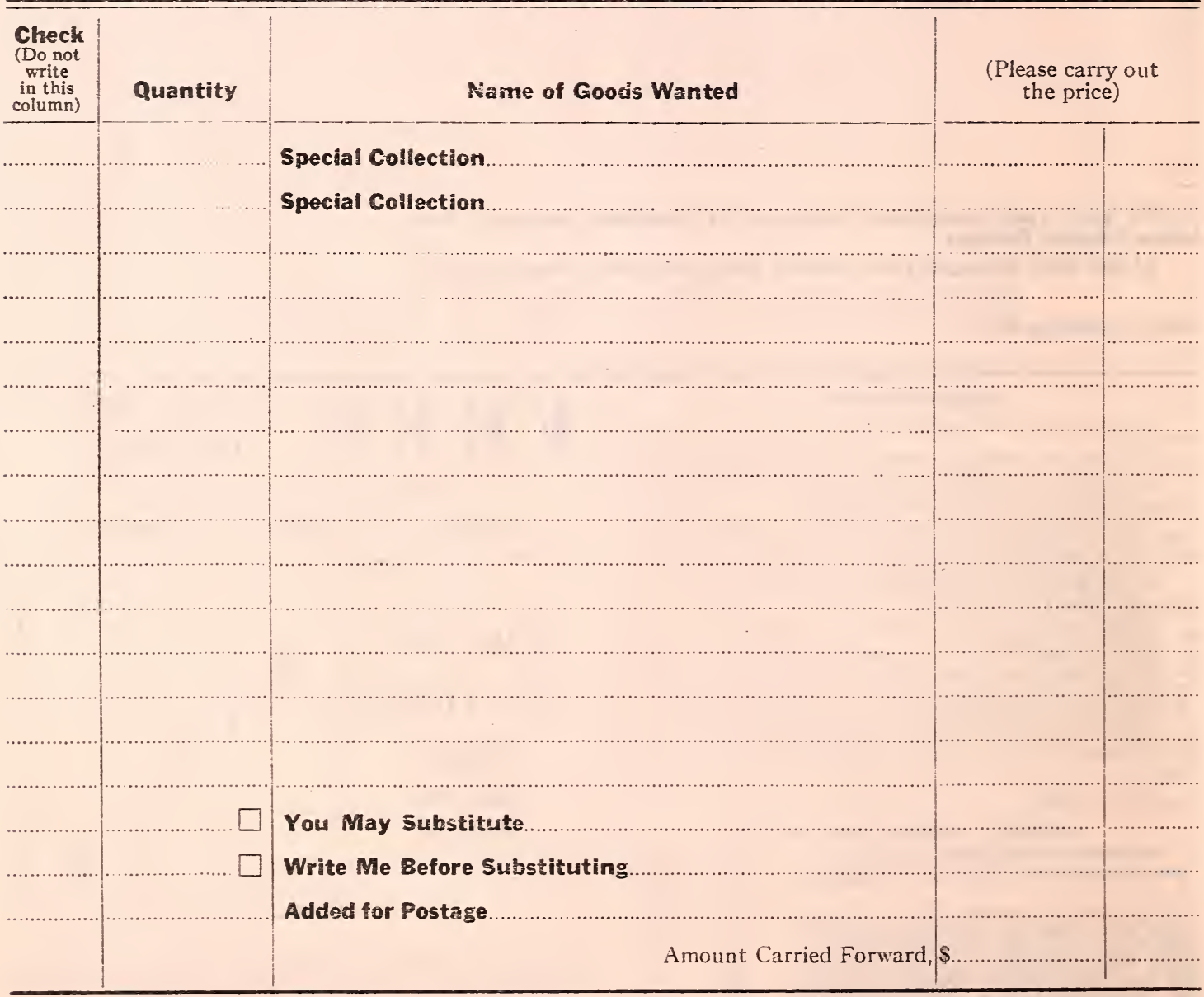




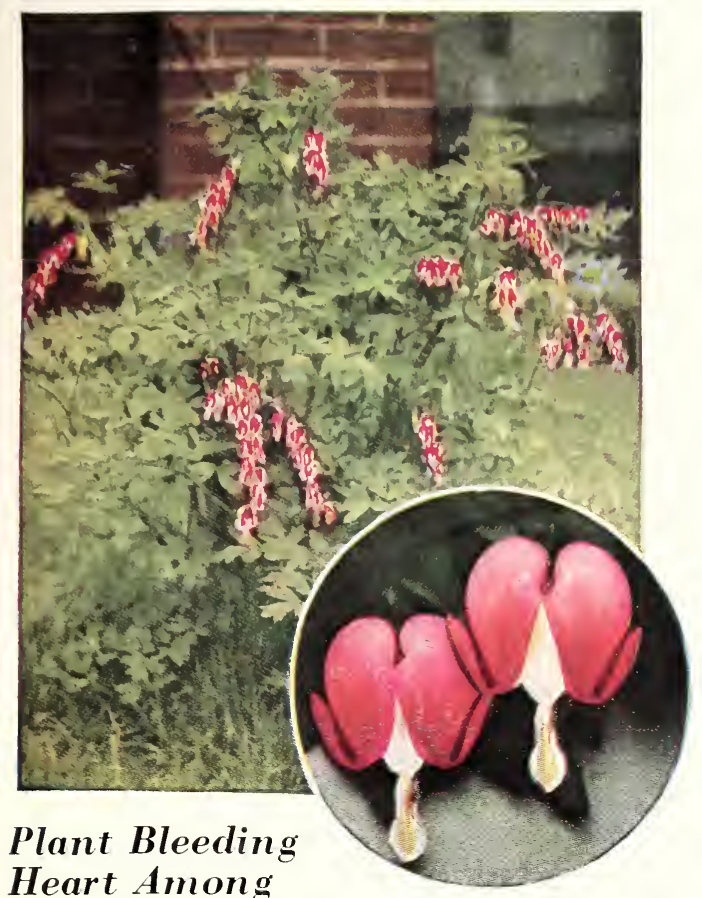

Heart Among

Your Evergreens and Hardy. Shrubs

It is an old-fashioned favorite. Its arching stems bear drooping heart-shaped flowers of white and rose-red. It is perfectly at home in any part of the hardy border and especially valuable for trast and is very effective Each 60c; postpaid.

OTHER FINE PERENNIALPLANTS ON PAGES 11 TO 14.

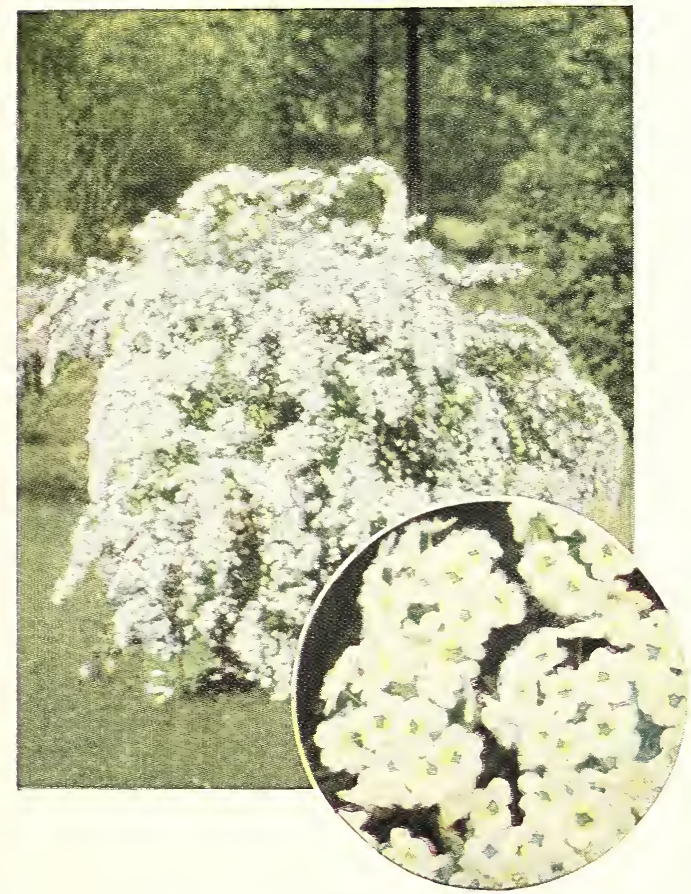

Bridal Wreath (Spirea I'an Houttii) Small Size. 18 to 24 inches. Each 40 c. By mail 50c. Standard Size. 3 to $4 \mathrm{ft}$., well branched. Each 60c. By

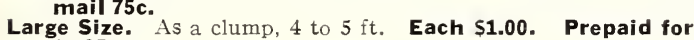
$\$ 1.35$.

TURN TO PAGES 24 AND 25 FOR SPECIAL SHRUB COLLECTION.

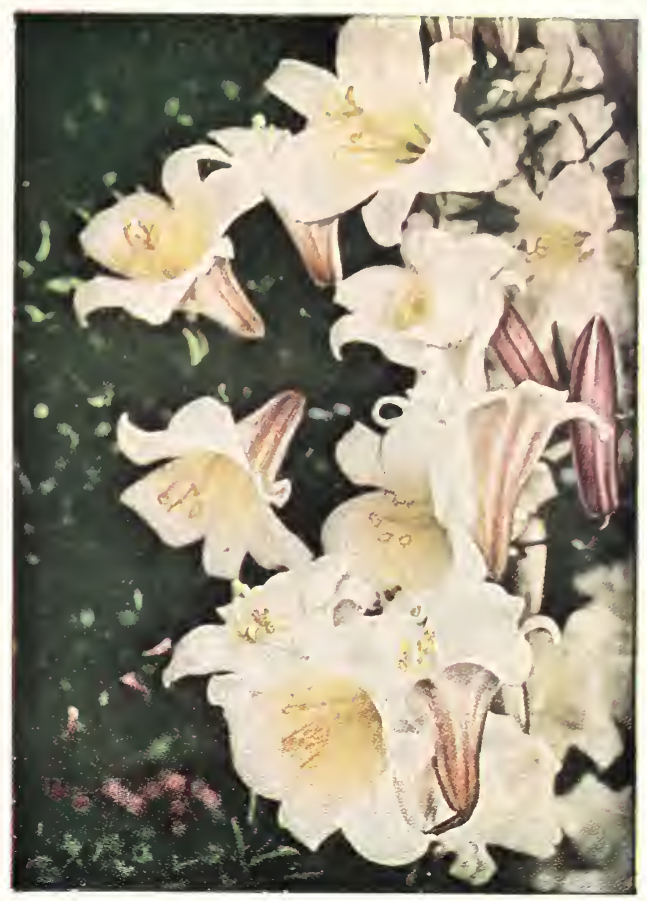

Regal Lilies-The Finest of All

The outstanding most popular lily. almost ivory-white, with a lively shade of pink, and a sheen of gold at the base of the petals that makes this one of the most beautifullilies. Delicately scented. Large Bulbs, each 45 c, postpaid.

COMPLETE LISTING OF HARDY LILIES ON PAGE 16.

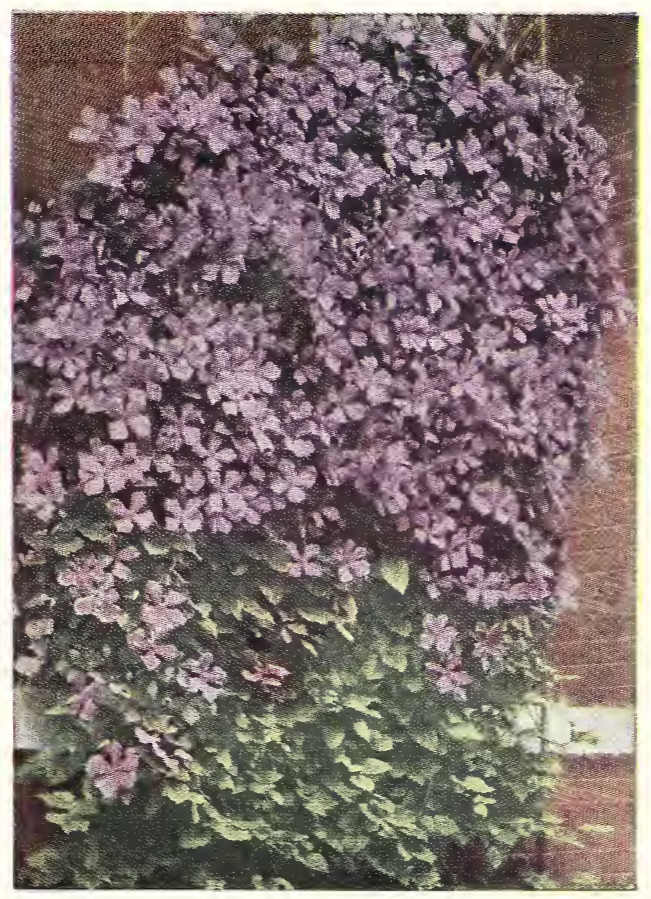

Clematis Jackmanni. (Large Floucering)

of all Clematis. Each, $\mathbf{\$ 1 . 0 0}$.

VINES FOR ALL PURPOSES LISTED ON PAGES 26 AND 27. 


\section{If only room for one flower, plant Zinnias}

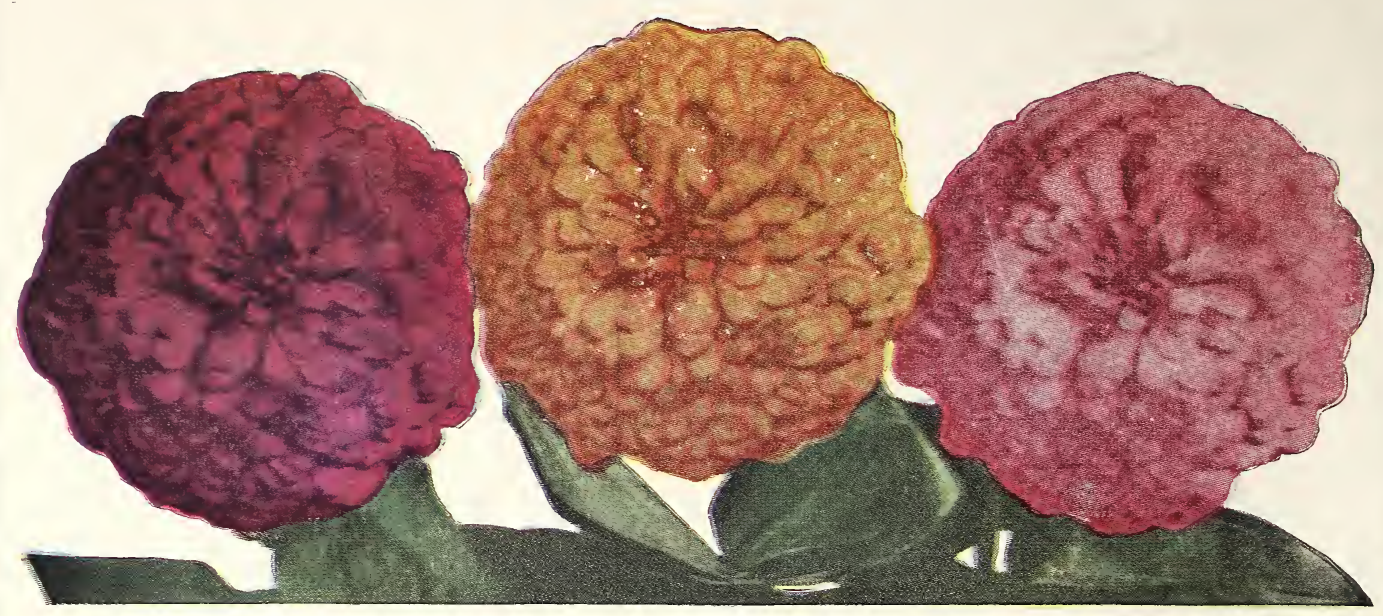

Three separate colors of Giant Dahlia-Flowered Zinnias

\section{EXTRA FINE ZINNIAS}

A magnificent annual, known by all lovers of flowers, and without any question the most satisfactory plant for bedding. The flowers are produced in great masses during the entire season and from the time the first flower opens till frost destroys them, they are never out of bloom. The flowers are of various shapes, some looking like an Aster and others again like a Dahlia, and all have a richness and variety of color which is simply astonishing. They should be planted in masses, either in separate colors or in mixture.

\section{Giant Dahlia-Flowered Zinnias}

The latest development in Zinnias, bearing flowers of mammoth size and in form somewhat like a double Dahlia.

The Bodger farm has achieved the climax in Zinnias and now offers the new Dahlia-flowered in separate pastel colors where blooms are 5 to 6 inches in diameter, never before known in Zinnias.

Illuminator. Deep rose, perfect form.

Crimson Monarch. Best red, immense size.

Exquisite. Light rose with the center a darker rose.

Polar Bear. Pure white; beautiful.

Canary Bird. Primrose or apricot, very attractive.

Oriole. Orange and gold bicolor, changing slightly.

Any of the Above: Each, pkt. 15c; $1 / 4$ oz. 50c; oz. $\$ 1.50$.

Special Dahlia-Flowered, Mixed. Seed gathered from many different varieties, including trial-ground plants. Pkt. 15c; $1 / 4$ oz. $40 \mathrm{c} ;$ oz. $\$ 1.25$.

\section{New Giant Flowered Mammoth Zinnias}

This variety is also known as the Colossal Zinnia. The stems of this variety are long; it is therefore excellent for cut flowers. Also excellent for use where you wish to carry out a color scheme-producing extra large blooms. Carried in separate colors; also mixture.

Pink. White. Orange. Scarlet, Violet. Yellow.

Any of the Above: Each, Pkt. 10c; 1/40z. 30c; oz. 90c.

Our Special Mixture. Pkt. 10c; $1 / 4$ oz. 25c; oz. 75c; $1 / 4$ Ib. $\$ 2.25$.

\section{Zinnias (Elegans)}

Excellent mixture of double flowers. Pkt. 10c; $1 / 4$ oz. 20c; oz. 50c.

\section{Lilliput or Pompon} oz. 25c.

mall double for bed or border. Mixed. Fine for cutting. Pkt. 10c; $1 /$

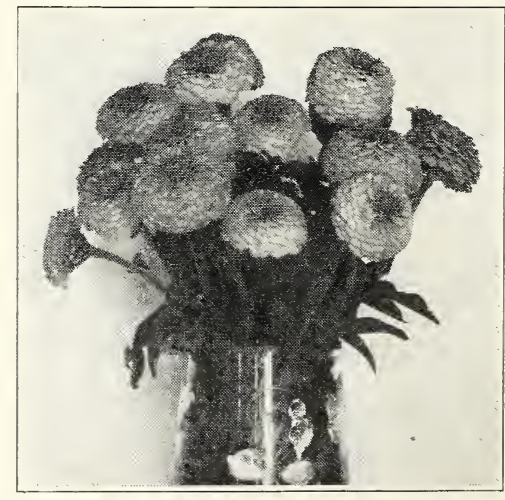

Lilliput or Pompon Zinnias

\section{Our Grand Collection of Mammoth Zinnias \\ 1 Pkt. Violet-Purple. \\ 1 Pkt. Rose-Pink. \\ 1 Pkt. Orange. \\ 1 Pkt. Scarlet. \\ 1 Pkt. White. \\ 1 Pkt. Mammoth Mixed. \\ All to you postpaid for $50 \mathrm{c}$. SIX LARGE 10c PACKETS FOR -.. 50 C}

1515 Champa St. The Coloradofeed Co. Denver, Colorado 